WHC-EP-0730

UC-702

\title{
The Influence of Small Mammal Burrowing Activity on Water Storage at the Hanford Site
}

\author{
D. S. Landeen
}

Date Published

September 1994

Prepared for the U.S. Department of Energy Office of Environmental Restoration and Waste Management

\section{(2) Westinghouse P.O. Box 1970 \\ Hanford Company Richland, Washington}

Hanford Operations and Engineering Contractor for the

U.S. Department of Energy under Contract DE-AC06-87RL10930

Approved for Public Release 


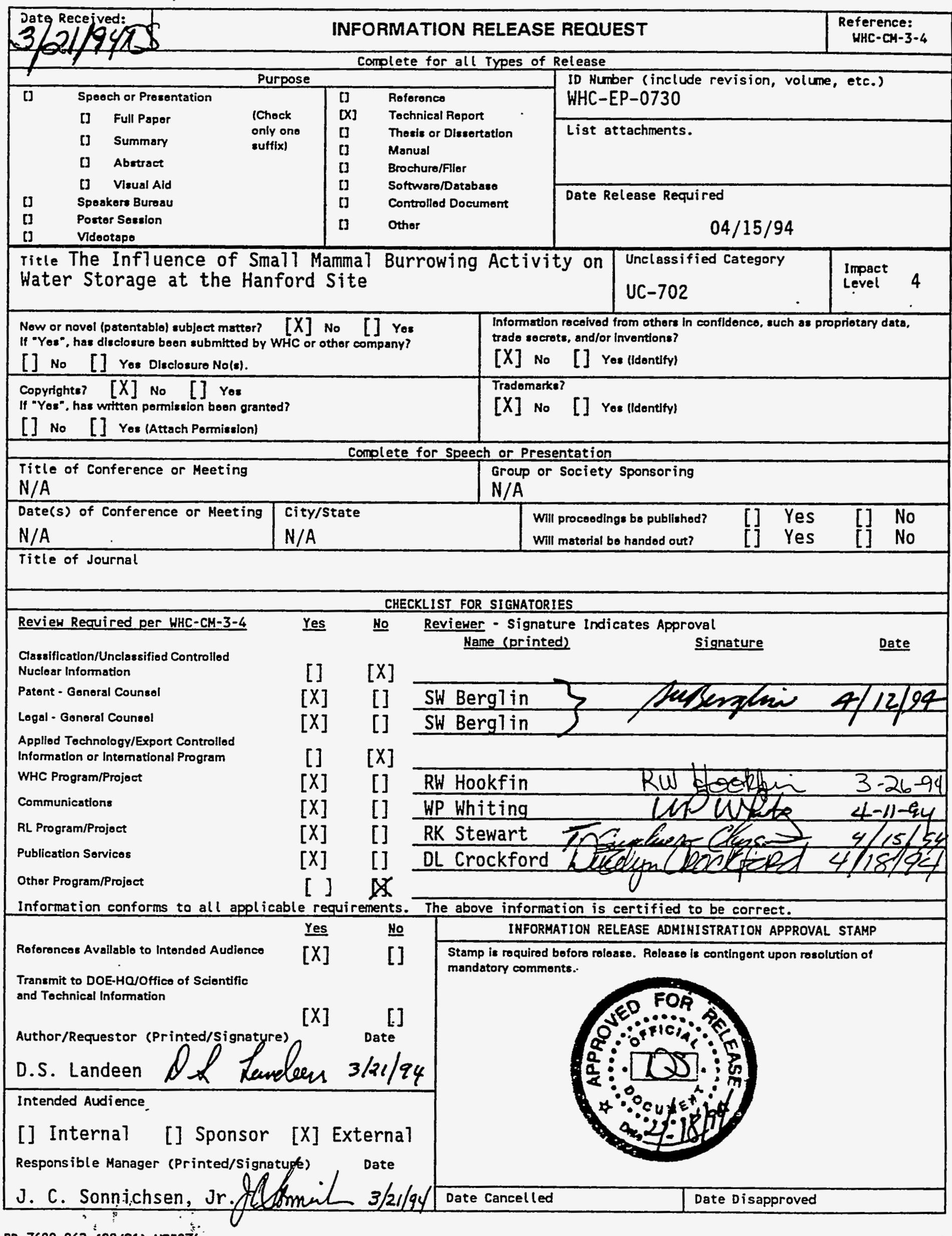

BD-7600-062 (08/91) WEFO74 


\section{DISCLAIMER}

This report was prepared as an account of work sponsored by an agency of the United States Government. Neither the United States Government nor any agency thereof, nor any of their employees, make any warranty, express or implied, or assumes any legal liability or responsibility for the accuracy, completeness, or usefulness of any information, apparatus, product, or process disclosed, or represents that its use would not infringe privately owned rights. Reference herein to any specific commercial product, process, or service by trade name, trademark, manufacturer, or otherwise does not necessarily constitute or imply its endorsement, recommendation, or favoring by the United States Government or any agency thereof. The views and opinions of authors expressed herein do not necessarily state or reflect those of the United States Government or any agency thereof. 


\section{DISCLAIMER}

Portions of this document may be illegible in electronic image products. Images are produced from the best available original document. 


\section{EXECUTIVE SUMMARY}

The Permanent Isolation Surface Barrier Development Plan identifies tasks that need to be completed to design a final protective barrier to implement in-place disposal of radioactive waste. The Biointrusion task focused on the need to evaluate the impacts that burrowing animals could have on the integrity of a protective barrier system. This report summarizes the animal intrusion work activities and literature surveys that were conducted by Westinghouse Hanford Company (WHC) in fiscal years 1988-1990 with respect to small mammals and water storage. The objective of this task was to determine the degree to which small mammal burrow systems affect the loss or retention of water.

An animal intrusion lysimeter facility was constructed and installed in fiscal year 1988. The facility consists of two outer boxes buried at grade that serve as receptacles for six animal intrusion lysimeters. At the beginning of each test the lysimeters were lined with a 28-mil plastic liner and filled with a fine soil from the McGee Ranch, a soil site near the intersections of State Highways 24 and 240 . Small burrowing animals common to the Hanford Site environs (pocket mice, pocket gophers, Townsend ground squirrels) were introduced during a 3- to 4-month period, and they were allowed to burrow. During the course of each test, supplemental precipitation was added monthly to three of the lysimeters with a rainfall simulator, at a rate equivalent to a Hanford 100 -yr storm. Soil moisture samples were taken before and after each test, while soil moisture measurements were taken with a hydroprobe during the test period. 
WHC-EP-0730

Five tests (three summer, two winter) were completed during the study period. Information collected from the tests indicated that (1) during summer months, water was lost in all the lysimeters, including the supplemental precipitation added with the rainfall simulator; (2) during winter months, lysimeters containing animals and controls (no animals) gained water; and (3) the data did not indicate that any long-term water storage had occurred as a result of burrowing activity.

The soil moisture profile graphs generated were indistinguishable from any of the five tests that lysimeters contained animals or the lysimeters that served as controls (i.e., contained no animals). This results of the study do not indicate that animal burrows at Hanford Site facilitate the retention of water at depth.

The lack of any significant water storage at depth and the overall water loss in the lysimeters occurred despite the following conditions that were imposed on the lysimeters: (1) no vegetative cover (therefore, no plant transpiration), (2) no water runoff (all water contained); (3) higher than normal animal and burrow densities, (4) supplemental precipitation added at rates not normally expected to occur, and (5) animals usually burrow to the bottom of the lysimeters.

The data indicate that little difference exists between control and animal lysimeters in the amount of water stored. Initially, during high-precipitation events when some burrows are open at the surface, water was able to infiltrate through the burrows faster and deeper than normal; however, within a relatively short period of time this excess water was removed. This was also observed in concurrent studies conducted at the 
Hanford Site regarding the effect of badger burrows on water distribution (Cadwell, 1991). If this is the case, then the overall water loss must be attributed to processes that occur equally in control and treatment lysimeters (surface evaporation). Other variables such as soil turnover and subsequent drying from burrowing activities and burrow ventilation affects assist in the removal of soil moisture, but the overriding factor is soil evaporation as a result of high ambient temperatures during the spring and summer.

This study did not address all potential climate changes, runoff events and potential effects of other burrowing animals. However, increased water storage at the Hanford Site under the present climatic conditions appear to be negligible, considering that a protective barrier will allow for runoff, have a vegetative cover, experience normal animal densities and normal precipitation events. Studies conducted elsewhere in environments that receive more natural precipitation and have lower ambient temperatures may not observe results as pronounced as those observed at the Hanford Site. 
WHC-EP-0730

This page intentionally left blank. 


\section{CONTENTS}

1.0 INTRODUCTION $\ldots \ldots \ldots \ldots \ldots \ldots \ldots \ldots \ldots \ldots \ldots \ldots \ldots \ldots \ldots$

2.0 LITERATURE SURVEY $\ldots \ldots \ldots \ldots \ldots \ldots \ldots \ldots \ldots \ldots \ldots \ldots \ldots \ldots$

2.1 Small Mammals and Invertebrates .................... 3

2.2 Large Pores and Channel Systems ................. 5

2.3 Large-Mammal Burrow Systems (badgers and coyotes) . . . . . . . . . 5

2.4 Prairie Dog Burrow Systems . . . . . . . . . . . . . . . 6

2.5 Burrow Air Pressures $\ldots \ldots \ldots \ldots \ldots \ldots \ldots \ldots \ldots \ldots$

2.6 Airflow Effects . . . . . . . . . . . . . . . . . . . . 9

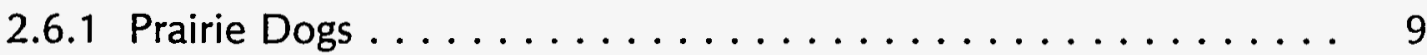

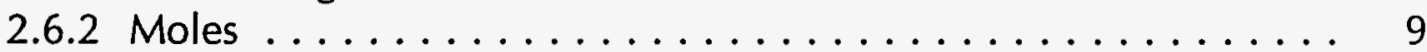

2.7 Burrow Humidity $\ldots \ldots \ldots \ldots \ldots \ldots \ldots \ldots \ldots \ldots \ldots \ldots \ldots$

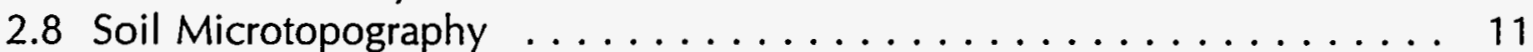

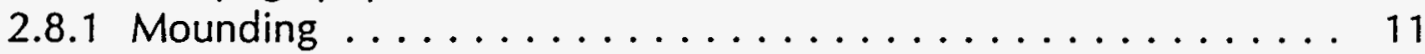

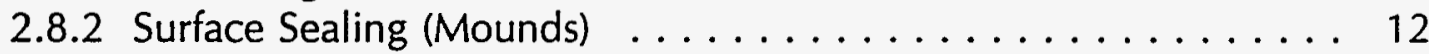

2.8 .3 Hummock/Swale Effects $\ldots \ldots \ldots \ldots \ldots \ldots \ldots \ldots \ldots \ldots 14$

2.9 Climate . . . . . . . . . . . . . . . . . . . 15

2.10 Small-Mammal Burrow Systems and Configurations . . . . . . . . 16

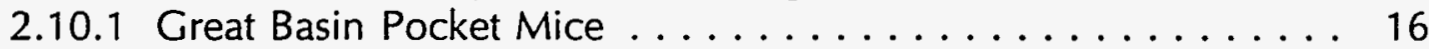

2.10 .2 Pocket Gophers . . . . . . . . . . . . . . . . 17

2.10.3 Townsend Ground Squirrel Burrow Systems . . . . . . . . . 19

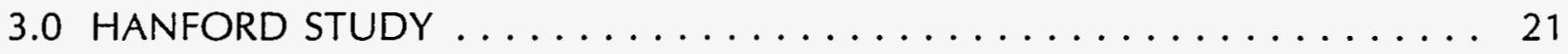

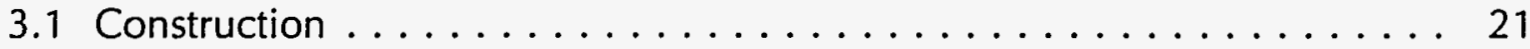

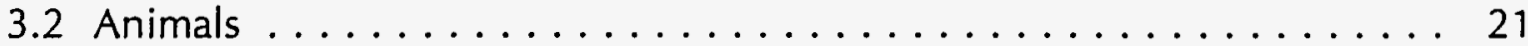

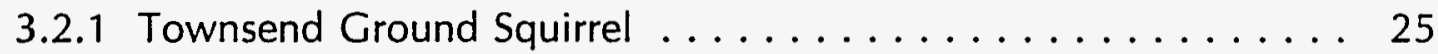

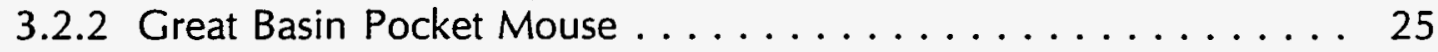

3.2.3 Northern Pocket Gopher . . . . . . . . . . . . . . . 25

3.3 Rainfall Simulator ........................ 27

3.4 Soil Moisture Measurements . . . . . . . . . . . . . . . . . . 27

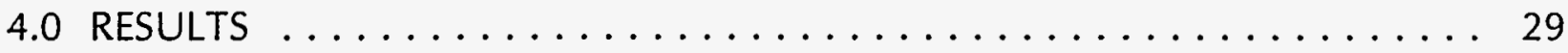

4.1 Test 1 (Summer Treatment) ...................... 29

4.2 Test 2 (Winter Treatment) . . . . . . . . . . . . . . . . 32

4.3 Test 3 (Summer Treatment) $\ldots \ldots \ldots \ldots \ldots \ldots \ldots \ldots \ldots \ldots \ldots$

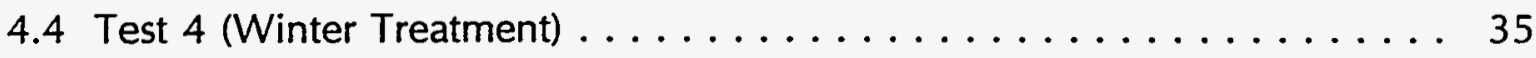

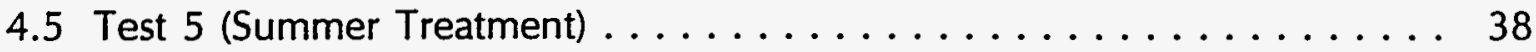

4.6 Burrow Configurations ..................... 41

4.7 Evaluation of Hanford Data $\ldots \ldots \ldots \ldots \ldots \ldots \ldots \ldots \ldots \ldots$

4.7 .1 Transpiration ................... 41

4.7 .2 Water Runoff ..................... 43

4.7 .3 Burrow Density .................... 44

4.7.4 Supplemental Precipitation $\ldots \ldots \ldots \ldots \ldots \ldots \ldots \ldots 44$

4.7 .5 Burrow Depths . . . . . . . . . . . . . . . . 44 


\section{CONTENTS (cont)}

4.8 Water Loss in Burrows . . . . . . . . . . . . . . . . . . . . . 44

4.8 .1 Soil Water Evaporation .................. 45

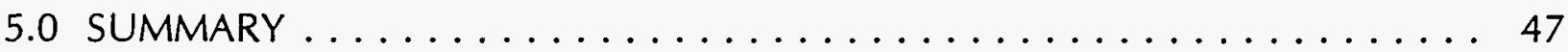

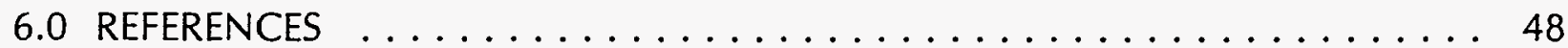

\section{APPENDICES}

A. Soil Moisture Profile Changes Calculated from the Gravimetric Soil Sampling at the Beginning and end of each Test . ................ A-1

B. Conductance and Hydroprobe Data (Collected for Tests 1 through 5) . . . . B-1

C. Soil Moisture Graphs Generated from Gravimetric Soil Sampling for Tests . . . C-1

D. Soil Moisture Graphs Generated from Conductance and Hydroprobe Data

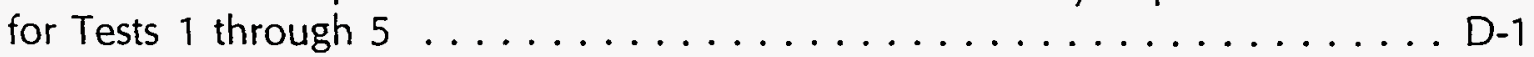

E. Great Basin Pocket Mouse Burrow Systems Excavated and Mapped at

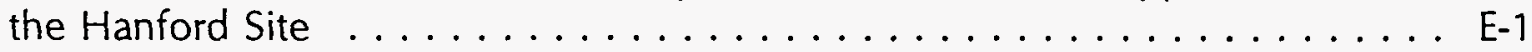

\section{LIST OF FIGURES}

1. Animal Intrusion Tasks Associated with Design of a Protective Barrier . . . . . 2

2. Hydrograph Showing the Effect of Shrew Burrows on Surface Runoff . . . . . . 4

3. The Channel System ........................ 6

4. Idealized Channel System States Representing Six Combinations of Soil Surface Roughness and Openness . . . . . . . . . . . . . . 7

5. Airflow in a Prairie Dog Burrow (Vogel et al. 1973) . . . . . . . . . . . 10

6. Humidity Measurements Inside and Outside a Kangaroo Rat Burrow . . . . . 11

7. Soil Water Storage Dynamics in Bare Swales, Irrigated Bare Swales, Spiny Hopsage Hummocks, and Irrigated Spiny Hopsage Hummocks (Cadwell, 1991).

8. Monthly Average Maximum and Minimum temperatures, 1924-1976, Inclusive; and Evaporation from a Free Water Surface, 1967-1976, Inclusive, at IREC (Kleingartner 1977) . . . . . . . . . . . . . . . . . . 16

9. Example of a Great Basin Pocket Mouse Burrow System Excavated at the Hanford Site . . . . . . . . . . . . . . . . . . . . 18

10. Average Rate of Infiltration for Pocket Gopher Mounds and Undisturbed Prairie Plots (time zero represents the beginning of the experiment) . . . . 20

11. Average Volumetric Soil Water Contents for Pocket Gopher Mounds and Undisturbed Prairie Plots (time zero represents the termination of the experiment) . . . . . . . . . . . . . . . . . . . . . 


\section{LIST OF FIGURES (cont)}

12. Location of the Animal Intrusion Lysimeter Facility . . . . . . . . . . 22

13. Experimental Design of the Small-Mammal Water Infiltration Study . . . . . . . 24

14. Soil Moisture Profile Changes Measured in Test $1 \ldots \ldots \ldots \ldots \ldots \ldots$

15. Soil Moisture Profile Changes Measured in Test $2 \ldots \ldots \ldots \ldots \ldots$

16. Hydroprobe Measurements Observed in Test $2 \ldots \ldots \ldots \ldots \ldots \ldots$

17. Hydroprobe Measurements Observed in Test $2 \ldots \ldots \ldots \ldots \ldots \ldots \ldots$

18. Soil Moisture Profile Changes Measured in Test $3 \ldots \ldots \ldots \ldots \ldots \ldots$

19. Hydroprobe Measurements Observed in Test $3 \ldots \ldots \ldots \ldots \ldots \ldots$

20. Soil Moisture Profile Changes Measured in Test $4 \ldots \ldots \ldots \ldots \ldots$

21. Hydroprobe Measurements Observed in Test $4 \ldots \ldots \ldots \ldots \ldots \ldots . \ldots \ldots$

22. Hydroprobe Measurements Observed in Test $4 \ldots \ldots \ldots \ldots \ldots \ldots \ldots . \ldots . \ldots . \ldots . \ldots$

23. Soil Moisture Profile Changes Measured in Test $5 \ldots \ldots \ldots \ldots \ldots . \ldots . \ldots$

24. Soil Moisture Profile Changes Measured in Test $5 \ldots \ldots \ldots \ldots \ldots . \ldots . \ldots$

25. Hydroprobe Measurements Observed in Test $5 \ldots \ldots \ldots \ldots \ldots \ldots \ldots . \ldots 40$

26. Hydroprobe Measurements Observed in Test $5 \ldots \ldots \ldots \ldots \ldots . \ldots \ldots . . . . .40$

27. Overview of All Abiotic and Biotic Factors That Influence Soil Moisture in Open and Closed Burrow Systems . . . . . . . . . . . . . . . . 46

\section{LIST OF TABLES}

1. Individual Lysimeters and Species Assignments Presented for all Five Tests . . 30

2. Summary of Overall Soil Moisture Changes Calculated from Soil Sample Collected at the Beginning and End of Each Test Period . . . . . . . . . . 31

3. Total Length (inches) and Maximum Depth of Burrow Systems for Tests 1-4 . . 43

\section{LIST OF PHOTOS}

1. Typical Badger Excavation at the Hanford Site . . . . . . . . . . . . . 8

2. Example of a Fresh Pocket Gopher Mound (1 day old) Excavated by Same Animal as shown in $3 \ldots \ldots \ldots \ldots \ldots \ldots \ldots$

3. Example of an Older Mound ( 1 month old) Excavated by Same Animal . . . . 13

4. Installation of an Animal Lysimeter ................... 23

5. Townsend Ground Squirrel in Native Habitat at the Hanford Site . . . . . . . 23

6. Great Basin Pocket Mouse in Native Habitat at the Hanford Site . . . . . . . . 26

7. Northern Pocket Gopher Excavating a Burrow in a Lysimeter . . . . . . . . 26

8. Soil Cast From Pocket Gopher Burrowing Activity in the Winter . . . . . . 28

9. Rainfall Simulator Applying Precipitation to Three Lysimeters . . . . . . . . 28

10. Cross-Section of. Pocket Gopher Burrow and Food Cache in One Lysimeter . . 42

11. Holes and Depressions Created by the Townsend Ground Squirrel Fill Up Rapidly during High-Precipitation Events $\ldots \ldots \ldots \ldots \ldots \ldots \ldots \ldots$ 
WHC-EP-0730

This page intentionally left blank. 


\section{THE EFFECT OF BURROWING ACTIVITIES OF SMALL MAMMALS ON WATER STORAGE AT THE HANFORD SITE}

\subsection{INTRODUCTION}

The amount and rate at which water may penetrate a protective barrier and come into contact with buried radioactive waste is a major concern. Because burrowing animals eventually will reside on the surface of any protective barrier, the effect these burrow systems may have on the loss or retention of water needs to be determined. Studies at the Hanford Site (Landeen and Mitchell, 1981 and 1982; Gano, 1979) and other U.S. Department of Energy (DOE) sites (Arthur et al., 1986; Hakonson et al., 1979; Winsor and Wicker, 1980; Garten, 1980) have documented the impact burrowing animals can have on the uptake and redistribution of radionuclides, but little quantitative information exists about the role borrowing activities of small burrows may have on the loss or retention of water.

The first section of this document summarizes the known literature relative to small mammals and the effects that burrowing activities have on water distribution, infiltration, and the overall impact of burrows on the ecosystem. Topics that are summarized include burrow air pressures, airflow, burrow humidity, microtopography, mounding, infiltration, climate, soil evaporation, and discussions of large pores relative to water distribution.

The second section of this document provides the results of the study that was conducted at the Hanford Site to determine what effect small mammal burrows have on water storage. This Biointrusion task is identified in the Permanent Isolation Surface Barrier Development Plan (Wing, 1993) in support of protective barriers. This particular animal intrusion task is one part of the overall animal intrusion task identified in Animal Intrusion Test Plan (Landeen et al., 1990) (Figure 1).

\subsection{LITERATURE SURVEY}

A survey of the scientific literature regarding the effects of animal burrow systems on water dynamics does not yield much conclusive or quantitative information. As noted by Ursic and Esher (1988), "the effect of burrows on hydrology has been largely overlooked." Studies on the effects of burrowing on water distribution are confounded by such factors as climate, soil texture, soil structure, soil temperature, soil layering, soil water content, pore size distribution, soil porosity, soil depth, surface slope, burrow configurations, species differences, and timing and intensity of natural precipitation events (Dixon and Peterson, 1971). The sections below summarize published data about the influence of animal burrows and large pore spaces related to the distribution, infiltration, and storage of water. 


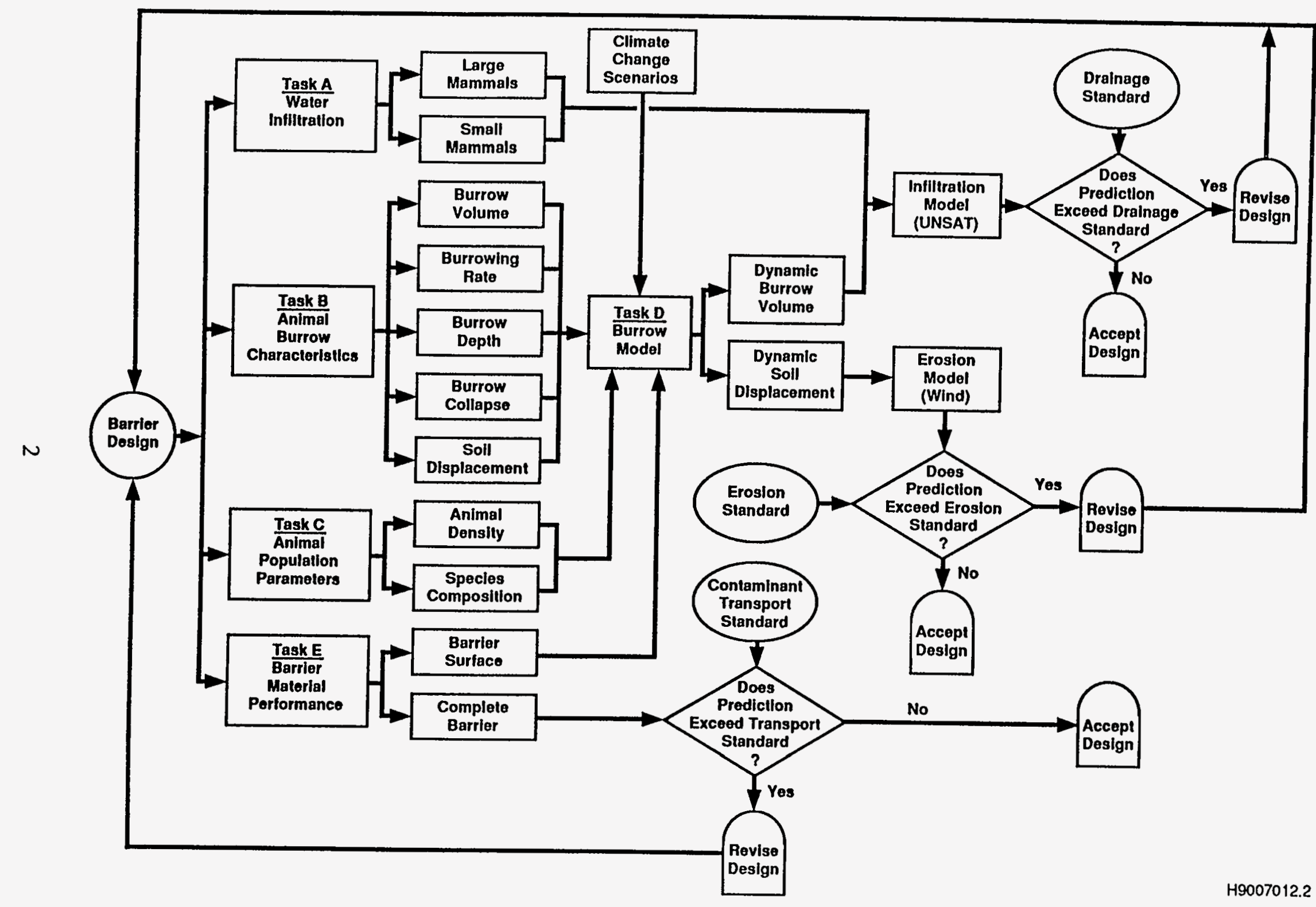




\subsection{Small Mammals and Invertebrates}

Studies by Day (1931) and Gabrielson (1938) suggested that pocket-gopher tunnels accumulate and channel runoff, thereby initiating gullies. However, other researchers (Grinnel, 1933; Taylor, 1935) thought that this would happen only rarely. Ellison (1946), in a study of the effects of erosion by pocket gophers in Utah, concluded that in instances of melting snow and rainstorms, gopher tunnels are insignificant in initiating gullies. Turner et al. (1973) concluded that pocket gophers cause patchy soil moisture conditions; increased infiltration existed where the gophers loosened the soil; and created depressions. However, when fine-soil particles from soil casts seal the surface (which results in rapid run-off from mounds), decreased infiltration occurs (Turner et al., 1973).

Popova (1962) observed that soil was wetter at a greater depth below bank vole burrows, but surface soils dryness increased along the route of some burrows, especially in pine forests. Olszewski and Skoczen (1965) observed that, in dry months, mole tunnels running under the surface of a pasture were marked with tracks of dried grass. Mole tunnels also were observed, in a freshly sown and harrowed field, to have caused the formation of dry streaks on the soil surface. Abaturov (1972) observed that the bulk density of the soil was decreased and infiltration increased in an area occupied by ground squirrels.

Dixon and Peterson (1971) concluded that large pores can have a profound effect on the infiltration of water into the soil, but they determined that water movement into large pores was related to subsurface microroughness and microporosity. Their air-earth model predicted that these two properties interact to funnel rainwater into the soil and displace air from the soil. Edwards et al. (1979) demonstrated that surface-connected holes can effectively transmit water when more water is applied to the soil surface than can infiltrate it. The effectiveness of the holes as water channels was governed by depth, diameter, and density.

Gardner (1962) demonstrated that pores not connected with the surface do not transmit water rapidly, but holes and cracks that are open at the surface can move significant volumes of free surface water much deeper and faster than can be calculated by Darcy-type solutions alone. Chichester and Smith (1978) looked at the movement of labeled fertilizer in some lysimeter experiments and concluded that large pore flow occurs only during or soon after heavy rainfall, and the fertilizer effectively bypassed water held in the small-pore soil matrix.

A study conducted in a forest ecosystem in Mississippi (Ursic and Esher, 1988) determined that the opportunity for detention and retention of rainfall was enhanced by the burrowing activities of shrews. The shrew burrows in that study were large and concentrated in the upper $15 \mathrm{~cm}$ of soil. The burrows were also frequently opened at the soil surface. Reductions in storm flow volumes 12 to $15 \mathrm{yr}$ after replacing poor quality, upland hardwoods with loblolly pine were only partially explained by increased interception of rainfall and transpiration. Much of the residual reductions were postulated to be caused by small mammal burrows. In simulated rain trials with short-tailed shrews, 
surface runoff decreased more than $25 \%$ (Figure 2). Overland flow for the design storm (Figure 14) was minimal during the first half of the application, during which $2.5 \mathrm{~cm}$ of water was applied in 15 minutes. The burrow then collapsed, and the hydrograph thereafter closely approximated the earlier runoff rates from the control plot. Mean runoff volumes in all simulated rainfall trials decreased by more than $25 \%$ despite the fragile burrows and more than $50 \%$ for 4 of the 12 runs.

Ehlers (1975) found that earthworm burrows reaching the surface improve water drainage, but those burrows not reaching the surface contribute little to infiltration. Because the majority of the earthworm burrows are blocked by soil particles, the channels do not share in water infiltration. Ehlers (1975) also noted that water infiltration through earthworm channels only occurred at high rain intensities, because at low intensities no tension-free water existed at the soil surface, and all the water infiltrated through the soil matrix according to hydraulic potential gradients. Hopp and Slater (1948) found that earthworms increased infiltration rates by a factor of four on tight, finetextured soils.

Figure 2. Hydrograph Showing the Effect of Shrew Burrows on Surface Runoff.

\section{Hydrograph Showing Effect of a Shrew Burrow on Surface Runoff}

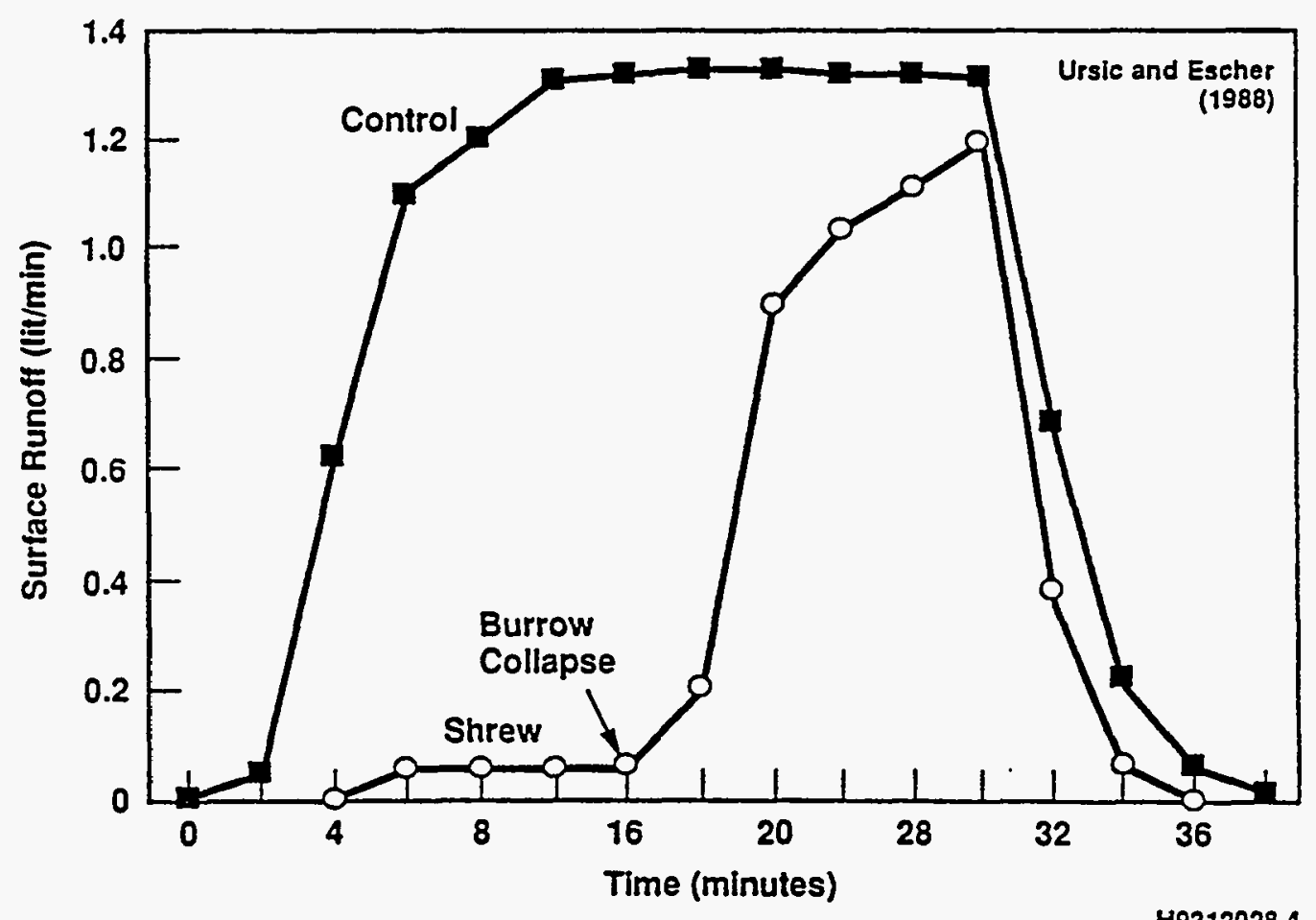




\subsection{Large Pores and Channel Systems}

The need for large pores to be open and exposed to free surface water before they can contribute to infiltration is inferred by Darcy's equation, which indicates that water moves only in the direction of decreasing hydraulic head. Hydraulic head always increases in the direction of a large pore isolated from free water by a surface seal. Dixon and Peterson (1971) conducted field experiments to test their channel system concept, which contends that a network of large soil pores, when functional, provide a subterranean arterial system for rapidly distributing free surface water to locations within the soil matrix and for exhausting soil air displaced from this matrix (Figure 3). The soil matrix referred to serves as a water storage sink called the capillary system.

The channel system includes the soil surface and a subsurface network of large pores that fill and drain mostly by gravity before and after the surface is exposed to free or ponded water. The channel system includes large pores produced by clay shrinkage, tillage, earthworms, ants, animal burrows, internal erosion, pebble dissolution, and entrapped air. In contrast, the capillary system comprises small pores within and between soil aggregates.

The rate and route of water infiltration in each system are controlled primarily by microtopography roughness and channel openness. Six different combinations of roughness and openness (called channel-system states) were studied (Figure 4). States A, $B$, and $C$ represented rough surfaces with open, constricted (i.e., unstable), and closed channel ports, respectively. States $D, E$, and $F$ represented plane or smooth surfaces with open, constricted, and closed channel ports (Figure 4), respectively. For state A, water penetration rates were rapid and flow routes relatively direct, whereas for state $F$, rates were slow and routes were extremely tortuous. The results supported the hypothesis that water penetration rates and routes are a function of the combination of soil surface openness and roughness.

\subsection{Large-Mammal Burrow Systems (badgers and coyotes)}

Cadwell et al. (1989) and Cadwell (1991) measured simulated rainfall events in large burrows dug by coyotes and badgers on the Hanford Site. Burrows excavated by coyotes and badgers are characterized by having large openings that are always open and exposed to the surface (Channel system A, Figure 4) (Photo 1). In simulated rainfall experiments, Cadwell et al. (1989) observed the diversion of surface water deep into the soils below and around the burrow systems; however, the water was subsequently withdrawn. Vegetation measurements showed that plant densities were significantly greater in the vicinity of badger burrows. This vigorous growth of invading plant species near burrows undoubtedly resulted in the extraction of water through plant transpiration. Enhanced evaporation from the soil surfaces exposed by burrowing also removed soil water near burrows. The data also showed that the soil beneath badger burrows in midsummer was drier than in adjacent soils away from the burrow sites. 


\subsection{Prairie Dog Burrow Systems}

If burrows do act as conduits for water to more easily infiltrate at depth, animals that excavate elaborate burrow systems with large openings might be more vulnerable to precipitation events. Prairie dogs, which are a lot larger than the species evaluated in this study, dig burrow systems that average $13 \mathrm{~m}$ long and $13 \mathrm{~cm}$ in diameter (Sheets et al., 1971). A large domelike mound is constructed from the excavated soil with a hole in the middle. These burrows are relatively permanent structures, and many probably have endured for centuries (King, 1984).

The large mounds are known to function as dikes to prevent the torrential rains of the prairie summers from flooding the burrows. Carlson and White (1987) investigated the effects of prairie dogs on mound soils and concluded that the soil genesis processes are slower beneath prairie dog mounds than beside the mound because precipitation moistens the mound materials more frequently than the underlying buried soil.

Figure 3. The Channel System. It consists of a (A) soil surface cover, (B) free water surface, (C) microdepressions, (D) a water intake orifice, (E) microelevation,

(F) air exhaust orifice, (G) subsurface channel, and (H) channel wall. The capillary system consists of (l) textural and structural pores within the soil mass (Dixon and Peterson, 1971).

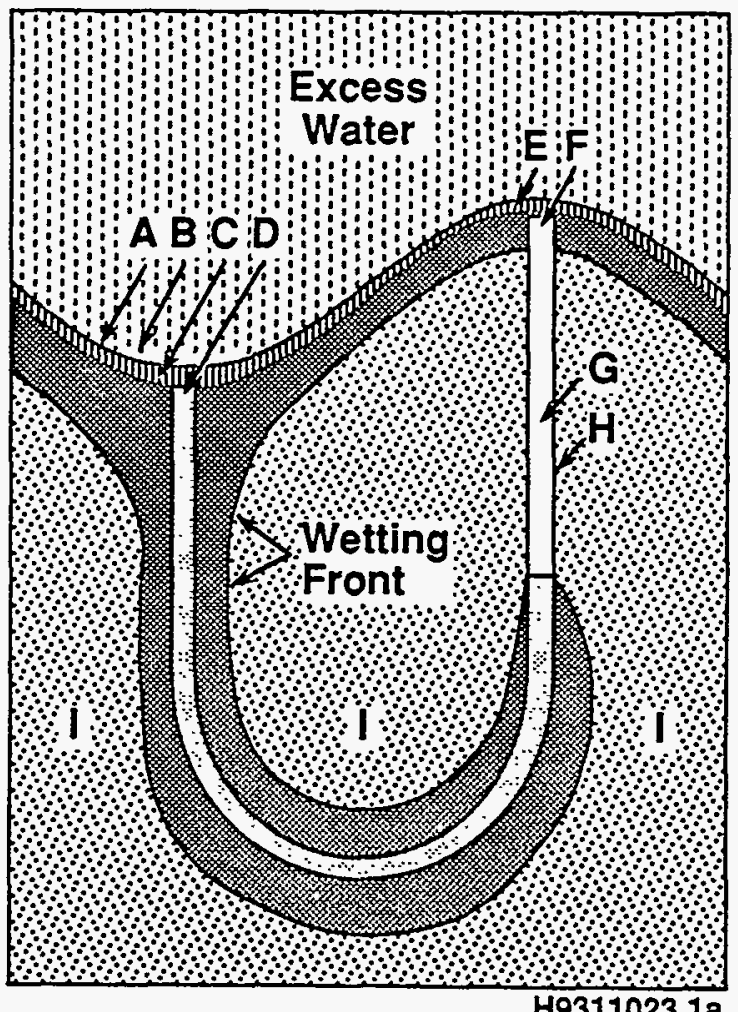


Figure 4. Idealized Channel System States Representing Six Combinations of Soil Surface Roughness and Openness.

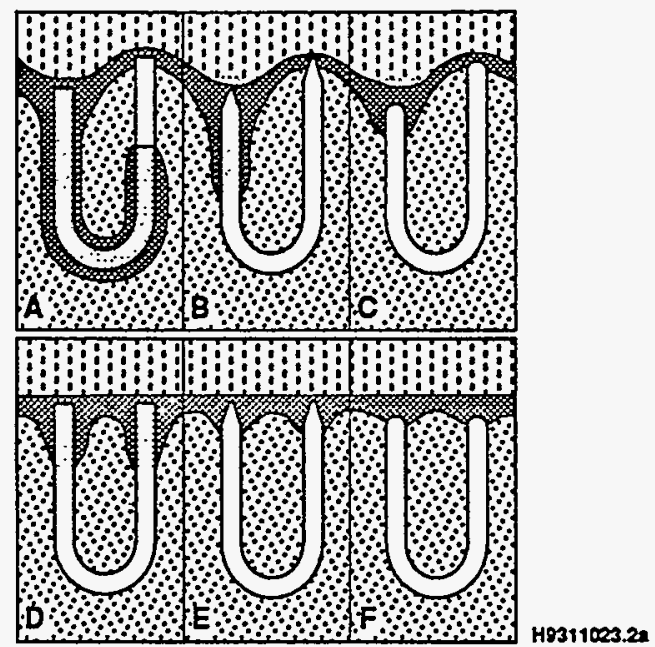

State A: A highly functional channel system that rapidly transfers and distributes free surface water to subsurface borders of the capillary system and readily exhausts displaced soil air. A soil with this type of channel system would have numerous stable open channel ports exposed to free water and some nearby open to the atmosphere. The soil surface is rough, open and covered with vegetation. This system would be similar to badger burrows and larger burrowing rodents such as prairie dogs and Townsend ground squirrels.

State B: Similar to state A except that the channel ports are unstable and constrict when exposed to free water. These constrictions impede water entry and air exit, consequently channel system $B$ contributes less to infiltration than system $A$. The extent of channel port constriction depends on the intensity of the water source. For instance, an intense rainstorm may completely close channel ports.

State C: State C differs from State B in that channel ports are completely closed. Infiltrating water cannot enter such channels until the bordering regions of the capillary system become saturated and not then if channel air pressure is above atmospheric. These closed channels function primarily as reservoirs for entrapped air, and thus as barriers to water movement within the capillary system. This system would be typical of pocket mice and pocket gophers. Both species plug burrow entrances which isolates burrow opening from any atmospheric contact.

State D: This state differs from State $A$ only by surface roughness, but this profoundly affects water flow since the flat surface of state $D$ favors lateral hydraulic balance. Under intense rainfall on sloping land, a thin, relatively uniform layer of water would accumulate on the $D$ surface. Ports would receive too little water for rapid water intake and too much for low-pressure exhausting of displaced air. Because of this inefficient port action, system D would contribute less to infiltration than system $A$.

State E: Similar to state D except that the soil surface lacks cover and is unstable. As in state B, channel ports constrict on exposure to free water. These constrictions reduce the infiltration contribution of system $E$ well below system $D$.

State $F$ : Sealing an E surface converts it to state $F$. The smooth, closed $F$ surface is hydraulically and pneumatically disconnected from subsurface channels, i.e., it is hydraulically isotropic. Under this state, infiltration is the lowest of all the states. Water must move along the small pathways of this system against increasing displaced soil air pressure. 
WHC-EP-0730

Photo 1. Typical Badger Excavation at the Hanford Site.

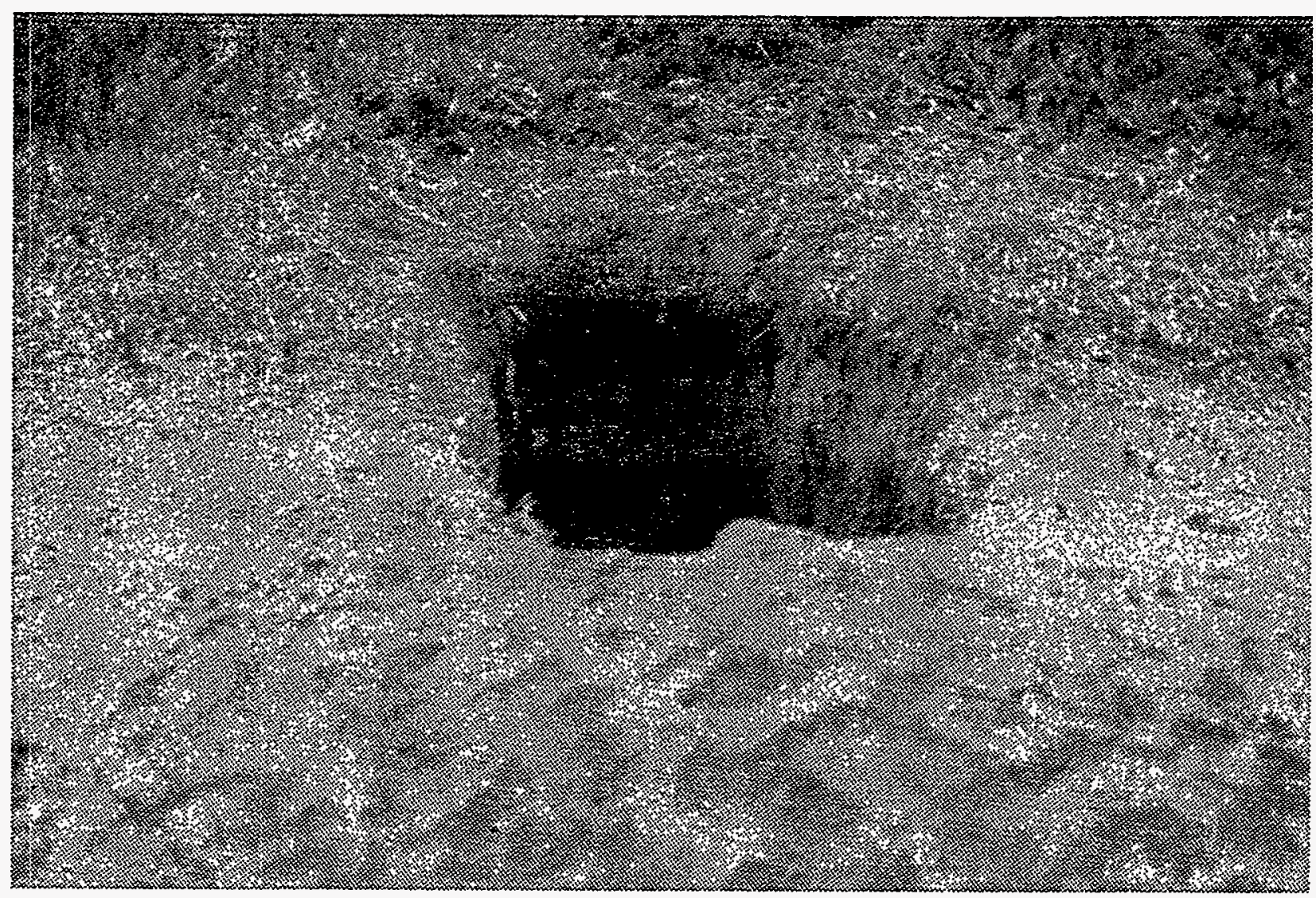




\subsection{Burrow Air Pressures}

Dixon and Peterson (1971) also indicated that soil air pressure studies support the channel system concept by showing that small air pressures greatly reduce infiltration. During natural rainfall conditions, water generally cannot enter the soil unless an equal volume of air escapes the soil surface. When channel openings are closed, they function primarily as reservoirs for entrapped air, and thus as barriers to water movement within the capillary system. Buildup in soil air pressure further limits infiltration under this state by blocking water flow in the larger structural pores of the capillary system. Wilson and Luthin (1963) observed soil air pressures up to $14 \mathrm{~cm}$ of water in homogeneous soil columns vented to the atmosphere and up to $110 \mathrm{~cm}$ in unvented columns. They indicated that soil air pressure reduces the number of large pores active in transmitting water. In a column experiment Horton (1940) showed that an entrapped air pressure of only $2.5 \mathrm{~cm}$ nearly reduced the infiltration rate by half.

Soil air pressures in burrow systems of the Great Basin pocket mouse and pocket gopher, which are common at the Hanford Site, are probably effective in limiting the movement of water into tunnels, because burrow entrances are plugged and isolated from any surface contact.

\subsection{Airflow Effects}

\subsubsection{Prairie Dogs}

Studies of prairie dog burrow systems have shown (Krebs and Davies, 1981; Vogel et al., 1973) how airflow ventilates the subterranean tunnels. Prairie dog tunnels are usually simple $U$-shaped passages with at least two openings to the surface. Vogel et al. (1973) indicated that the mounds around the burrow entrances were different. A high steep sided 'crater' mound exists at one end, and at the other end a low rounded 'dome' exists (Figure 5). When a breeze crosses the mounds, air enters the burrow through the lower mound and leaves through the higher. This keeps the burrow systems dry and reduces soil moisture at depth.

\subsubsection{Moles}

Two distinct openings may not be an absolute requirement for airflow in a burrow system. Olszewski and Skozen (1965) put anemometers in mole burrows that lacked obvious openings and entrances. Mole burrow systems are similar to those of pocket gophers. Olszewski and Skozen found that air speeds in the burrows correlated with wind speeds above. However, in the case of an atmospheric calm, the airflow in the burrows was lower but constant, probably as a result of differences in air density, which is caused by temperature differences. They were also able to demonstrate that air enters the tunnel systems through freshly excavated mole hills, which drips out the tunnels (thermoregulation) and provides oxygen for the burrow inhabitants. 
Figure 5. Airflow in a Prairie Dog Burrow (Vogel et al., 1973).

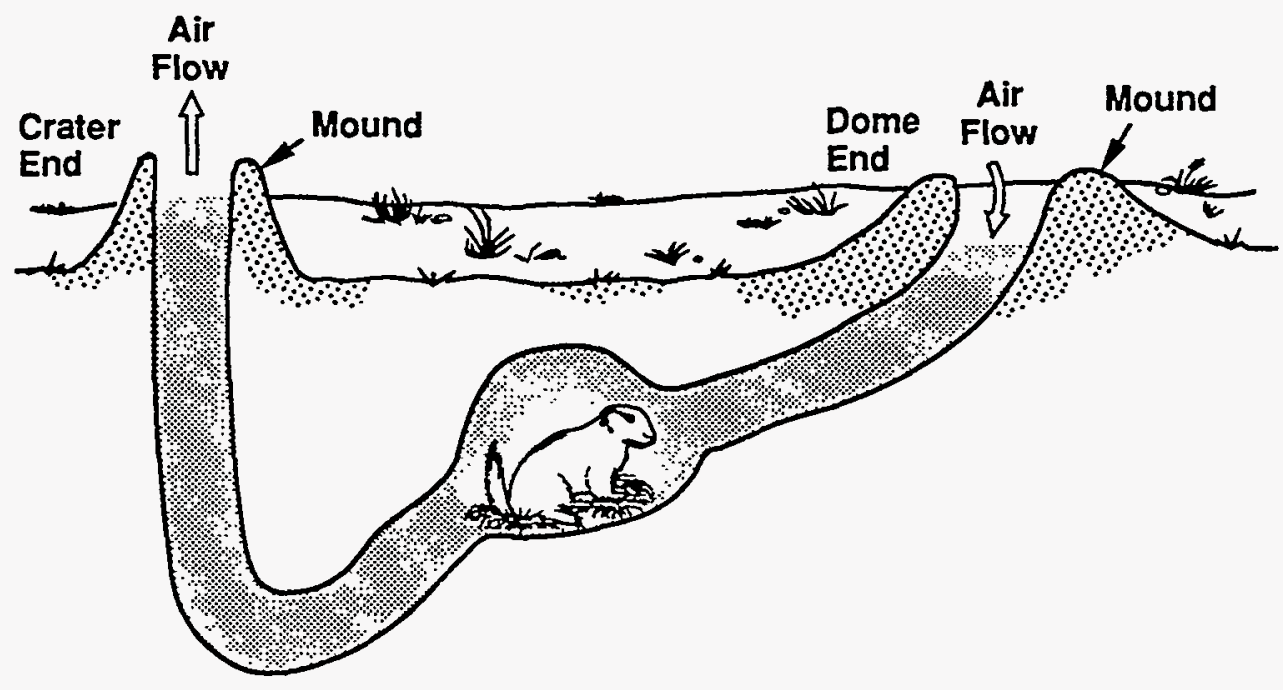

H9311023.14

Olszewski and Skozen (1965) also observed that, after heavy precipitation events, numerous ventilating openings turn up in the tunnel systems. This has the result of intensifying airflow in the burrows which probably warms and dries the burrows as quickly as possible. Winter temperature measurements of these burrow systems found that the walls of nest chambers were covered with hoarfrost in many cases, whereas the tunnels were warm and dry.

\subsection{Burrow Humidity}

Burrow systems must be constructed in such a way that desert rodents optimize the expenditure of water through excretion and evaporation from the lungs. Schmidt-Nielsen and Schmidt-Nielsen (1950) investigated the burrow microclimate in burrow systems of two species of kangaroo rats in Arizona at the driest and hottest time of the year. Their data showed that definite ventilation effects existed that kept tunnels dry and that the amount of water vapor in the burrows was two to five times higher than the outside air (Figure 6). Their investigations showed that even during the driest season the soil contains enough water to keep a closed air space in the ground at $30 \mathrm{~cm}$ saturated with water vapor. They also noted that, after one rainfall of $4 \mathrm{~mm}$ during the study, a marked influence on burrow air humidity existed. 
WHC-EP-0730

Figure 6. Humidity Measurements Inside and Outside a Kangaroo Rat Burrow.

Humidity Measurements Kangaroo Rat

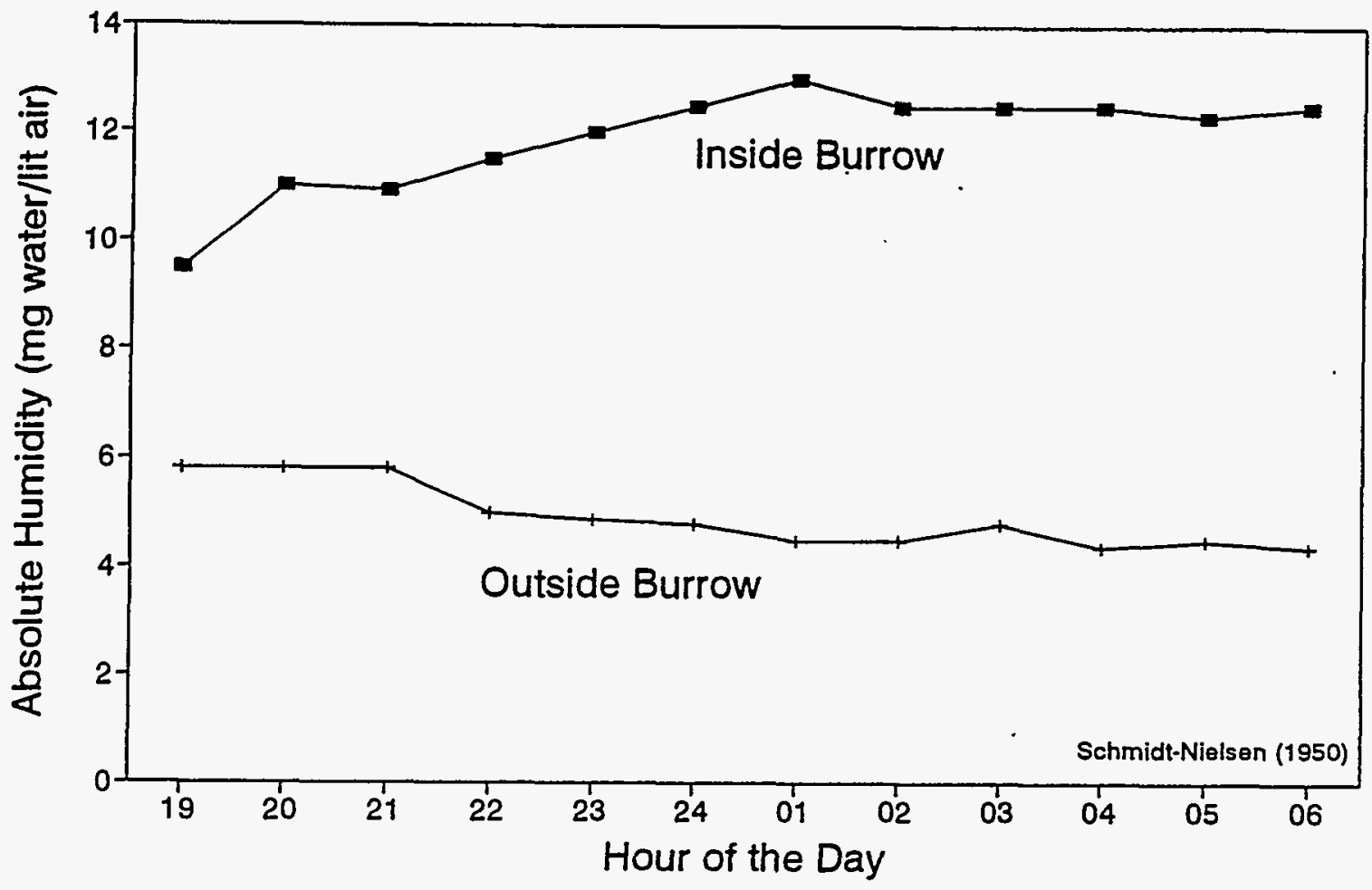

\subsection{Soil Microtopography}

\subsubsection{Mounding}

Several species of burrowing animals are known to significantly alter the surface soil topography and soil structure (Johnson et al., 1987), which can cause patchy soil moisture distributions. Studies of burrowing behavior by pocket gophers have suggested that these animals are instrumental in forming many of the Mima mounds that are widespread west of the Mississippi River, from southern British Columbia to northern Mexico (Arkley and Brown, 1954; Cox and Hunt, 1990). Much of the Columbia Plateau of eastern Washington, northeastern Oregon, and southwestern Idaho is covered by Mima-mounded grassland. Over time the formation of these mounds can create a swale and hummock effect, which creates patchy soil moisture conditions away from the mounds where burrow entrances are located.

Arkley and Brown (1954) excavated pocket gopher burrows as part of Mima mound investigations and noted that the nests were located just below the crest of the dome (Figure 19). The method by which the gopher accumulates soil into a mound is explained by (1) the tendency to place the nest in a well-drained spot where the soil is the deepest, thus, generation after generation of gophers may keep building nests near the crest of any high spot in the land surface, or over a window in a hardpan; and 
(2) gophers when tunneling move soil beneath the body and force the soil backward to a surface opening. Thus, over a long period of time, the gopher, by digging outward to form a nest, tends to move the soil toward the opening, which allows the mound to rise gradually. Arkley and Brown (1954) also documented areas in Oregon where mound areas grew 12 in. $(30.48 \mathrm{~cm})$ in $22 \mathrm{yr}$.

In some areas of California, ground squirrels are so abundant that they have an enormous effect on soil morphology and also create Mima moundlike surface microtopography (Borst, 1968). Earth material excavated by the squirrels form mounds up to several meters in diameter and $0.75 \mathrm{~m}$ high. The mounds range in particle size from clay to cobbles up to $15 \mathrm{~cm}$ in diameter. These animals are the dominant pedogenic agents in the soils of this area. Water distribution is affected when patchy soil moisture conditions are created from the uneven microtopography.

Studies of moles in pasture areas of Poland (Skoczen et al., 1976) indicated that the number of mole hills per hectare ranged from 4,107 to 21,063 . The percent of the occupied surface by the molehills fluctuated between 4.3 and $11.2 \%$. Their study on the influence of mole tunnels on soil moisture distribution after natural precipitation events showed that the presence of mole tunnels had a drying influence on the adherent soil layers both in the post-dry period and after rainfalls. The study also observed that a moisture increase existed at tunnel ends immediately after a rainfall, suggesting that soil layers may be humidified by water running along and seeping from tunnels. They concluded that there is a general tendency towards drying.

\subsubsection{Surface Sealing (Mounds)}

Mounds formed by the Great Basin pocket mouse and northern pocket gopher evolve gradually from mounds that are characterized as moist loose excavated puffs of soil to older mounds that become sealed and harder as a result of fine soil particles that fill in the micropores. In the initial stages these mounds serve as a sponge during rainfall events. In the latter stages, as these mounds undergo settling, they become relatively impervious to water penetration and facilitate runoff away from burrow entrances (Photos 2 and 3).

In an evaluation of surface factors affecting the rate of intake of water by soils, Duley (1939) observed that the rapid reduction in the rate of intake by cultivated soils (as rain falls on the surface) was accompanied by the formation of a thin, compact layer at the soil surface, and the water was able to pass through this layer only slowly. Duley (1939) postulated that this thin, compact surface layer was caused by a structural disturbance, caused in part by the beating of rain and the sorting action of wind and water, which allows fine soil particles to be fitted around the larger ones to form a relatively nonpervious seal. Duley's data showed that the thin, compact layer that forms at the soil surface of cultivated soils during rains had a greater effect on intake of water than did the soil type, slope, moisture content, or profile characteristics. 
Photo 2. Example of a Fresh Pocket Gopher Mound (1 day old) Excavated by Same Animal as Shown in Photo 3.

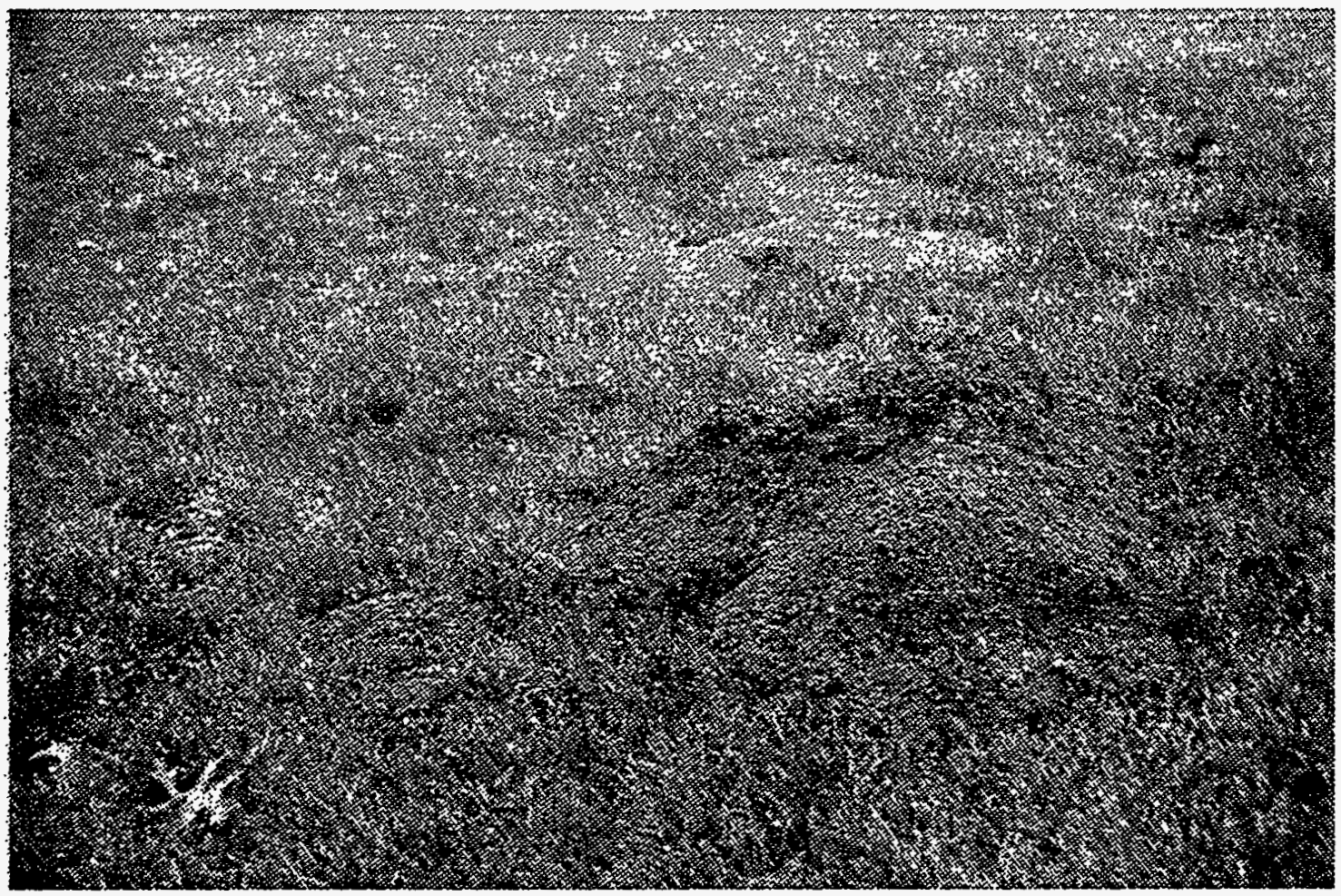

Photo 3. Example of an Older Mound (1 month old) Excavated by Same Animal. (The old mound has settled and so sheds water more easily.)

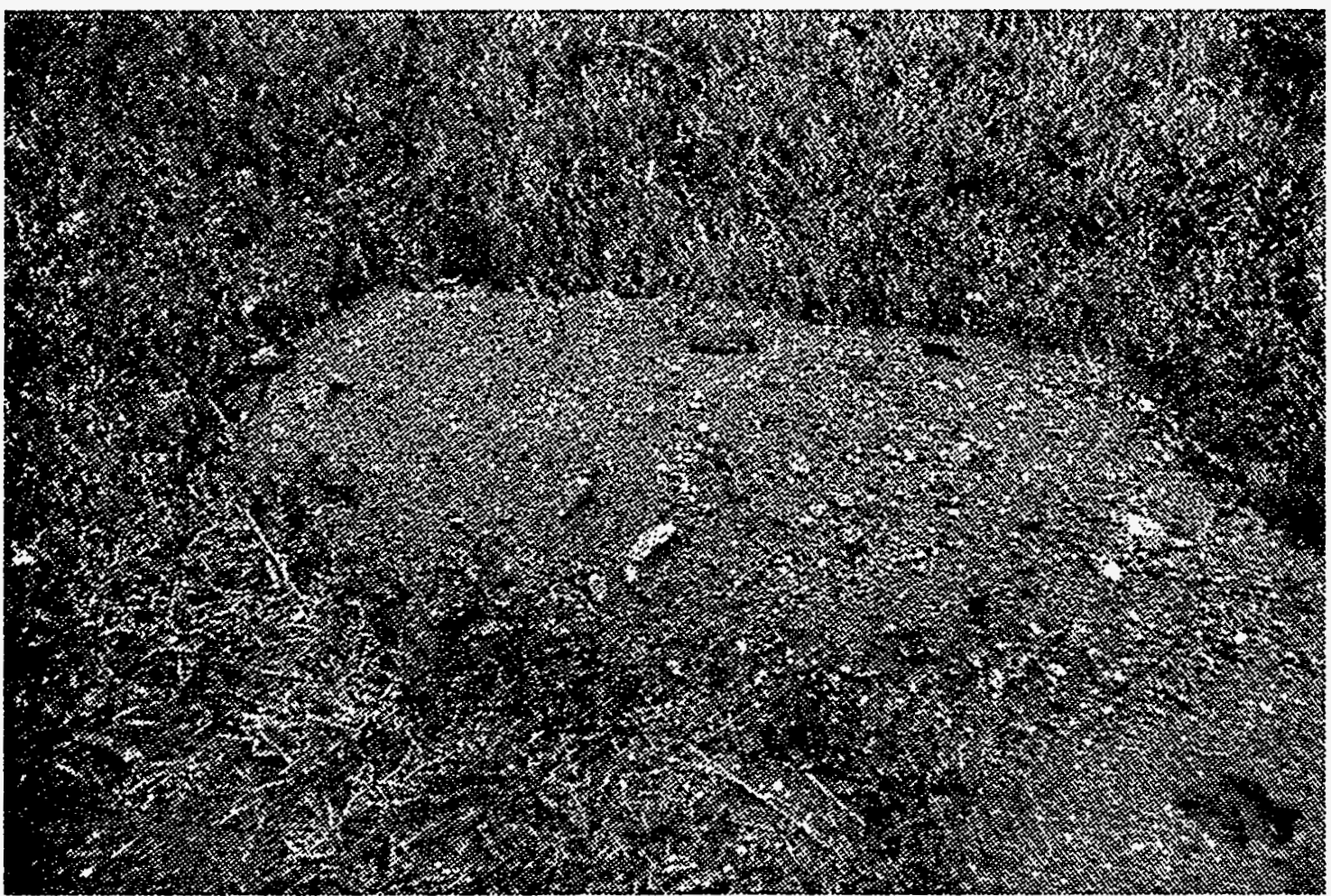




\subsubsection{Hummock/Swale Effects}

Many studies have indicated that the availability of soil moisture, which is mostly determined by topography, is a major factor in controlling species distributions (Barnes and Harrison, 1982). As mentioned previously, burrowing animals have been documented to cause hummock/swale effects. Patchy soil moisture conditions, which are caused by hummock/swale topography, were investigated at the Hanford Site (Cadwell, 1991; Link et al., 1994). The objective of the study was to determine if relationships exist between hummock/swale topography and soil water dynamics under normal and enhanced precipitation regimes. Three conditions were tested in the study: (1) hummocks dominated by spiny hopsage, (2) bare swales, and (3) swales dominated by sagebrush. The data indicated that coppice dune topography and related vegetational patterns caused patterns in soil water storage and soil water content with depth. Bare swales were wetter than either hopsage hummocks or sagebrush swales, while hopsage hummocks and sagebrush swales were not significantly different (Figure 7). The effect of adding supplemental precipitation on end-of-season soil water storage. and profile patterns in the study was negligible. The Hanford Site semi-arid ecosystem can recycle to the atmosphere at least twice the normal precipitation, given that additional water comes in the spring. This study indicated that all supplemental precipitation that was added had been recycled to the atmosphere within 215 days.

Figure 7. Soil Water Storage Dynamics in Bare Swales, Irrigated Bare Swales, Spiny Hopsage Hummocks, and Irrigated Spiny Hopsage Hummocks (Cadwell, 1991).

\section{Soil Water Dynamics in Hummock/Swale}

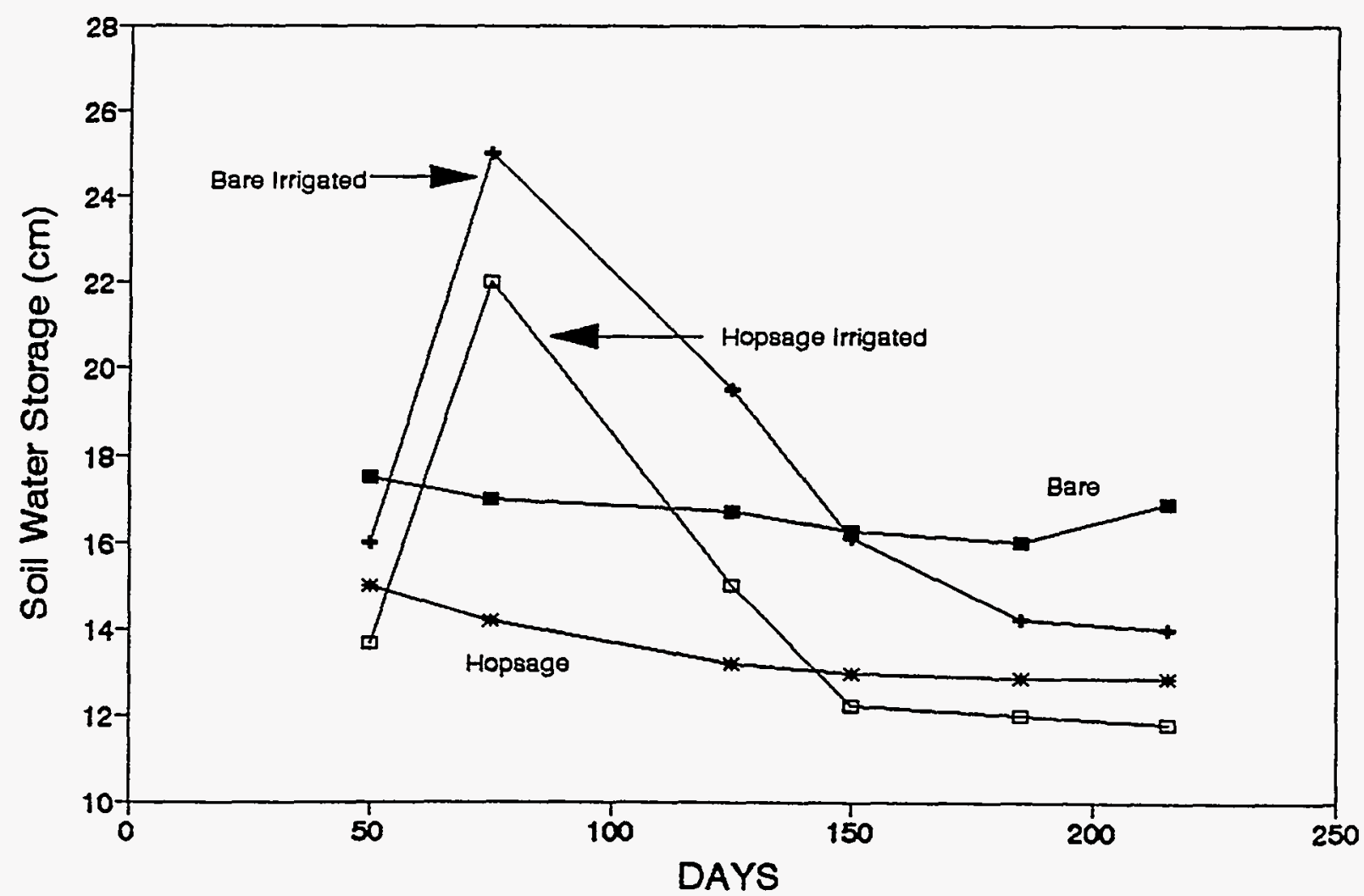


Other studies at the Hanford Site have shown a seasonal effect regarding the addition of supplemental precipitation (Wildung and Garland, 1988). They found no effect of supplemental precipitation on soil water contents in coppice dunes and swales when irrigated in the spring. However, they observed increased soil water levels in irrigated hummocks in the fall and winter, which was maintained after subsequent irrigation in the spring.

\subsection{Climate}

Climatic conditions can have profound effects on soil water dynamics. The Hanford Site study discussed below was conducted in an area of Washington State that is hot from the end of March to October. The average annual precipitation received at the Hanford Site does not exceed 6 in. $(15 \mathrm{~cm})$. The summers are warm with low humidity and a high percentage of clear days. The high daily temperatures, the considerable sunshine, and the long days favor rapid plant growth when supplemental precipitation is added.

Data from the Irrigated Research and Extension Center (IREC) near Prosser, Washington indicate that the total evaporation from April to October, inclusive, is 49.9 in. $(127 \mathrm{~cm})$ (Kleingartner, 1977). On the basis of the data from IREC, the average evaporation is 5.78 in. $(15 \mathrm{~cm})$ in April, increases to 10.09 in. $(26 \mathrm{~cm})$ in July, and decreases in August $8.5 \mathrm{in} .(21.5 \mathrm{~cm})$. Further decreases in September and October are sharp. The evaporation correlates with the average maximum and minimum temperatures (Figure 8). In many water-deficient areas, such as the Great Plains, $60 \%$ of the precipitation is estimated to be evaporated back to the atmosphere (Hanks et al., 1967).

Campbell and Harris (1977) studied water losses from a sagebrush community in eastern Washington during a drought year (1973) and a higher-than-normal-precipitation year (1974). During 1973 the total precipitation was $14.6 \mathrm{~cm}$. Evaporation was estimated to be $6.5 \mathrm{~cm}$ ( $45 \%$ of precipitation). In 1974 precipitation was $35.7 \mathrm{~cm}$ and $8.2 \mathrm{~cm}$ or $23 \%$ was estimated to be lost to evaporation. These observations can be used to infer the effect on desert ecosystem production of increasing or decreasing annual precipitation. At the beginning of the 1974 growing season the soil was filled to $100 \%$ field capacity so additional early spring precipitation would not have changed transpiration or production significantly. The excess moisture could only have gone to deep drainage or evaporation.

Campbell and Harris (1977) concluded that reduced precipitation would decrease water available for transpiration in two ways: the input would be less, and smaller rains would result in a larger fraction of the moisture being lost to evaporation. The result would be a greater decrease in production than proportionate to the decrease in precipitation. 
Figure 8. Monthly Average Maximum and Minimum temperatures, 1924-1976, Inclusive; and Evaporation from a Free Water Surface, 1967-1976,

Inclusive, at IREC (Kleingartner 1977).

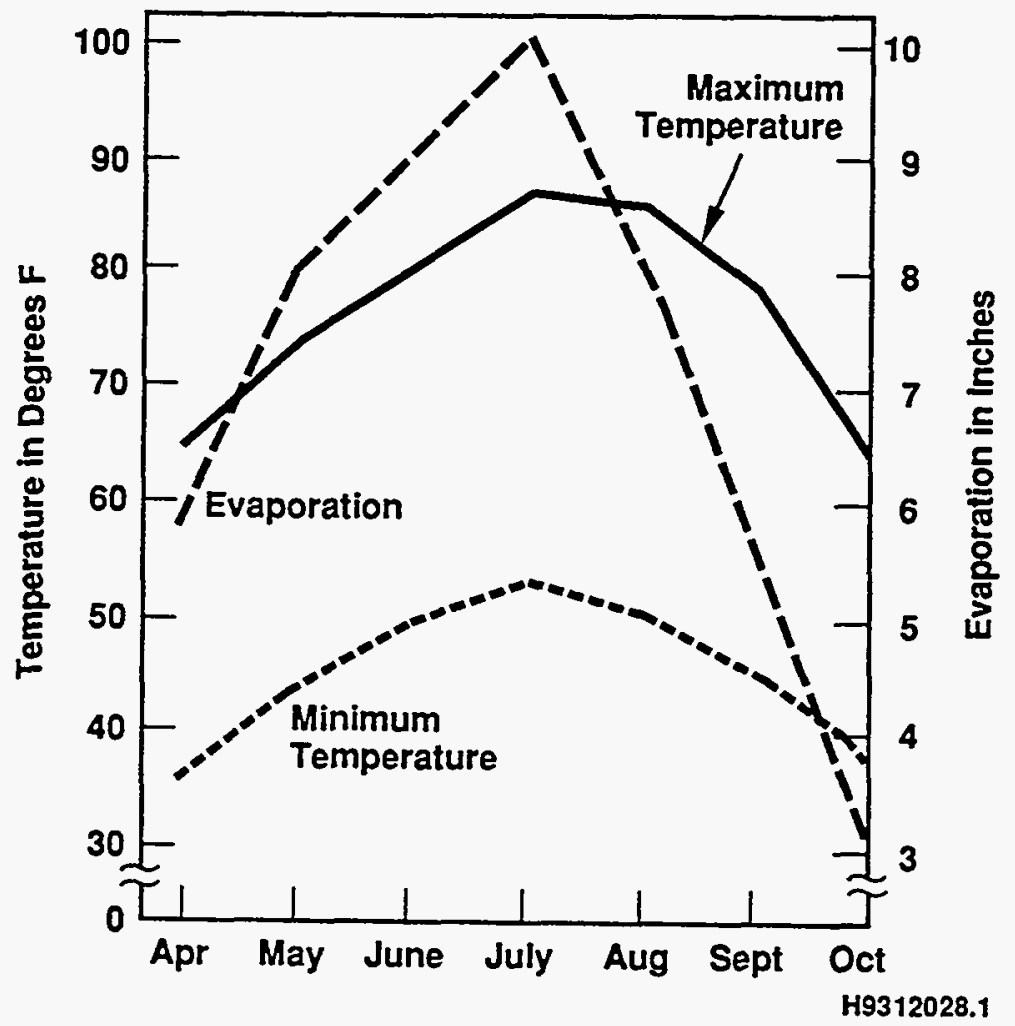

\subsection{Small-Mammal Burrow Systems and Configurations}

The configuration of small-mammal burrows is such that the six-channel system states described by Dixon and Peterson (1971) are probably represented at one time or another in many burrow systems by many different burrowing animals. Depending on the species, burrows can be relatively simple with few entrances or complex with many entrances and exits (Reynolds and Laundre, 1988). The particular kind of burrow system can affect water distribution as illustrated in the channel system states previously discussed (Figure 4).

\subsubsection{Great Basin Pocket Mice}

Scheffer (1938) excavated burrow systems of Great Basin pocket mice in eastern Washington and found complex and extensive burrow systems, reaching depths of 1.0 to $1.5 \mathrm{~m}$, including nest chambers, seed caches, and several branches from 3.0 to $4.5 \mathrm{~m}$ long.

Complex burrow systems for the Great Basin pocket mouse also were verified at the Hanford Site by Kritzman (1974) and Landeen and Mitchell (1981). Landeen and Mitchell (1981) also indicated how pocket mice construct distinctive mounds, which often are part of a larger mound system that may be elevated above the normal 
landscape. These mounds form slopes that can facilitate runoff away from burrow entrances, located on these mounds.

Burrow systems excavated by the Great Basin pocket mouse, which is the most common small burrowing mammal found on the Hanford Site (Fitzner and Gray, 1991), probably most closely correspond to channel system states C, B, and A (in that order). Channel system $C$ is one where channel ports are completely closed. Like many desert rodents, the Great Basin pocket mouse plugs the entrances and exits to the burrow system, effectively isolating the burrow from any surface contact (Scheffer, 1938). An example of a Great Basin pocket mouse burrow system excavated and mapped at the Hanford Site is presented in Figure 9. Appendix E shows other Great Basin pocket mouse burrow systems excavated at the Hanford Site.

\subsubsection{Pocket Gophers}

Pocket gopher burrow systems also closely resemble channel system $C$ described above (Figure 4). Pocket gophers are prolific burrowers and, like the Great Basin pocket mouse, plug burrow entrances and also backfill tunnels that are no longer wanted (Cameron et al., 1988). Thorne and Anderson (1990) followed a single adult pocket gopher for 158 days and recorded $112 \mathrm{~m}$ of tunnel length. Soil excavated during the tunnel construction was deposited in 134 mounds, 68 plugs, and $77 \mathrm{~m}$ of backfilled tunnels.

Ross et al. (1968) suggested that pocket gopher mounds are, in effect, "puffs" of soil formed by animals disturbing and mixing the soil in a particular spot. Mounds created by pocket gophers in Minnesota were compared to the surrounding undisturbed soil (Ross et al., 1968). The mounds were characterized as having lower bulk densities and lacking a definite soil structure, which resulted in increased water permeability. During precipitation events, mounds act as water buffers because initially more water infiltrates into the mound than the surrounding soil. However, within a short time the water is removed through evaporation and mounds actually become drier than the underlying soil. The increased water permeability observed in mounds is more pronounced when the mounds are relatively young. After the soil has been exposed to the environment, mounds sometimes become somewhat hardened as pore spaces are filled by fine soil particles and, in many cases, facilitate runoff from the mound.

Grant et al. (1980) measured water infiltration rates and volumetric water contents in pocket gopher mounds in Colorado and verified the conclusions stated previously by Ross et al. (1968). Rates of infiltration of rainfall and evaporation of soil water were measured on five mounds and on five undisturbed areas with a rainfall simulator for 15 minutes after a simulated rainfall event. Soil cores were taken at 6-hour intervals up to 72 hours, and they were analyzed for percent of moisture. 
Figure 9. Example of a Great Basin Pocket Mouse Burrow System Excavated at the Hanford Site.

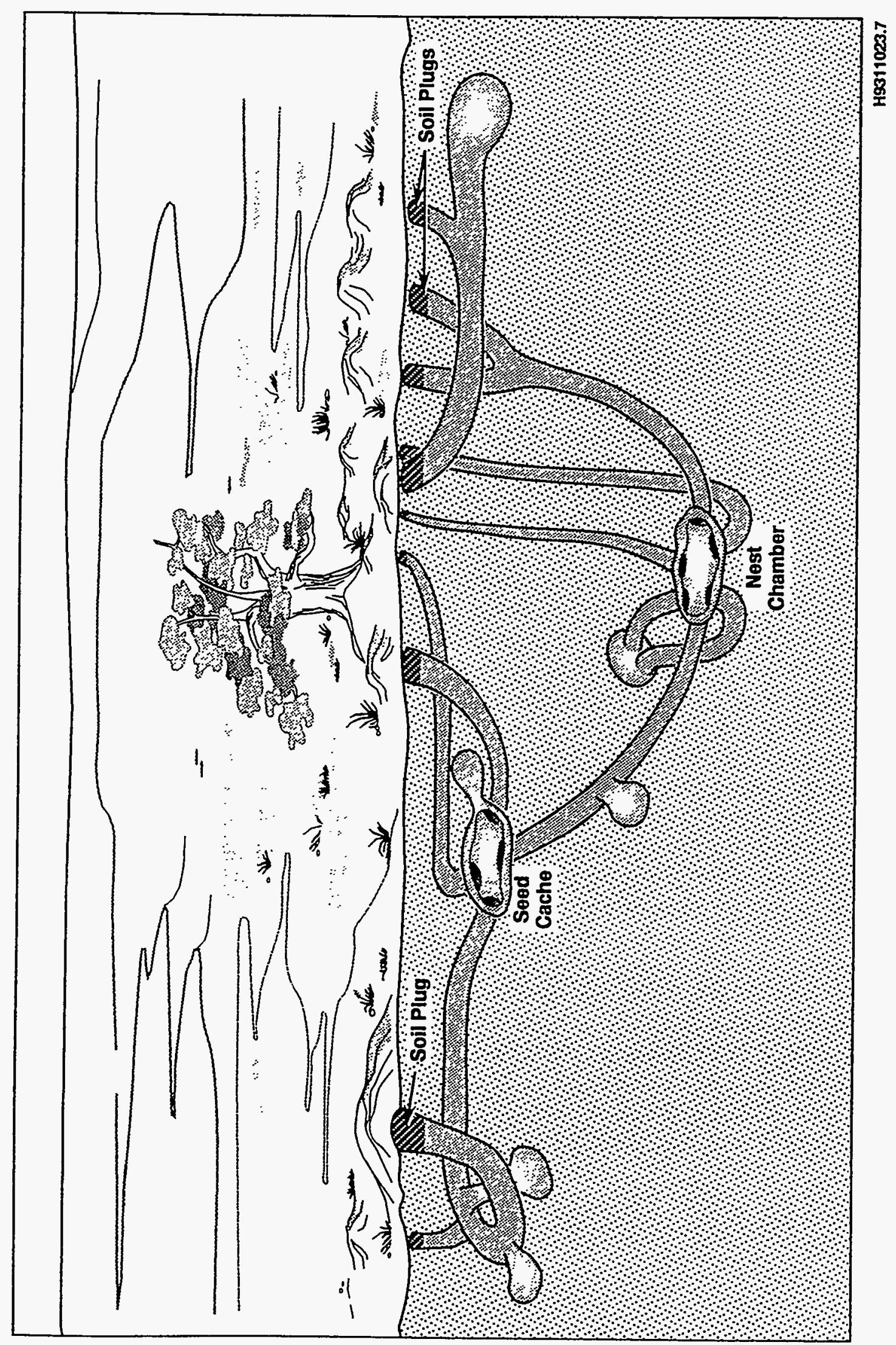


The data of Grant et al. (1980) (Figure 10) indicated that infiltration rates were significantly higher on mounds than on undisturbed areas $(p<0.05)$. Figure 11 , which shows the average volumetric soil water content versus time for mounds and undisturbed areas indicates that essentially all evaporation (and percolation) occurred within 24 hours after the simulated rainfall events. The marked drop in soil water that occurred during the first 6 hours (Figure 11) was caused primarily by evaporation. The slight rise in soil water content between 54 and 66 hours was from natural rainfall. Overall, they found the average volumetric soil water content for mounds and undisturbed areas was not significantly different.

Grant et al. (1980) also reported that the density of vegetation immediately adjacent to the pocket gopher mounds was significantly higher than vegetation density $50 \mathrm{~cm}$ from the edge of mounds. This increase did not appear to be caused by the increased soil water content. While infiltration rates are significantly higher on mounds than on undisturbed prairie, the resulting differences in soil water content are neither large nor persistent (Figure 11). Grant et al. (1980) surmised that the increased plant density was a response to increased nutrient availability. This difference in soil chemistry also has been observed in harvester ant mounds (Rogers and Lavigne, 1974) and in prairie dog mounds (Carlson and White, 1987).

Ellison and Aldous (1952) observed that vegetation production was greater when pocket gophers were present, which reduced water infiltration in the soil from transpiration. McDonough (1974) also noted that mound building and soil turnover activities by pocket gophers favored the maintenance of aggressive perennials at high densities.

\subsubsection{Townsend Ground Squirrel Burrow Systems}

Townsend ground squirrel burrow systems are more similar to prairie dog burrow systems than the other two rodent species evaluated in this study. Townsend ground squirrels are larger than pocket mice and pocket gophers and often create large mounds of excavated soil around areas with entrance and exit holes similar to prairie dogs. There are no studies that have documented burrow ventilation effects in Townsend ground squirrel burrows, but there probably is airflow in Townsend ground squirrel burrow systems. These entrances and exits are seldom plugged and maintain continuous contact with the surface.

Water entry into these burrow systems does not appear to cause stress or harm to these species. Two things these species do that mitigate the effects of intense precipitation events are found in the burrow configuration: (1) burrow systems are complex and branch in many different upward and sideward directions (Manville, 1959; Shaw, 1925), so during extreme precipitation events, waterflow is probably diverted into many side channels before it can reach storage sites and nesting areas; and (2) mounds can act as dikes to divert water from the burrow. 
Figure 10. Average Rate of Infiltration for Pocket Gopher Mounds and Undisturbed Prairie Plots (time zero represents the beginning of the experiment).

\section{Average Rates of Infiltration Pocket Gopher Mounds}

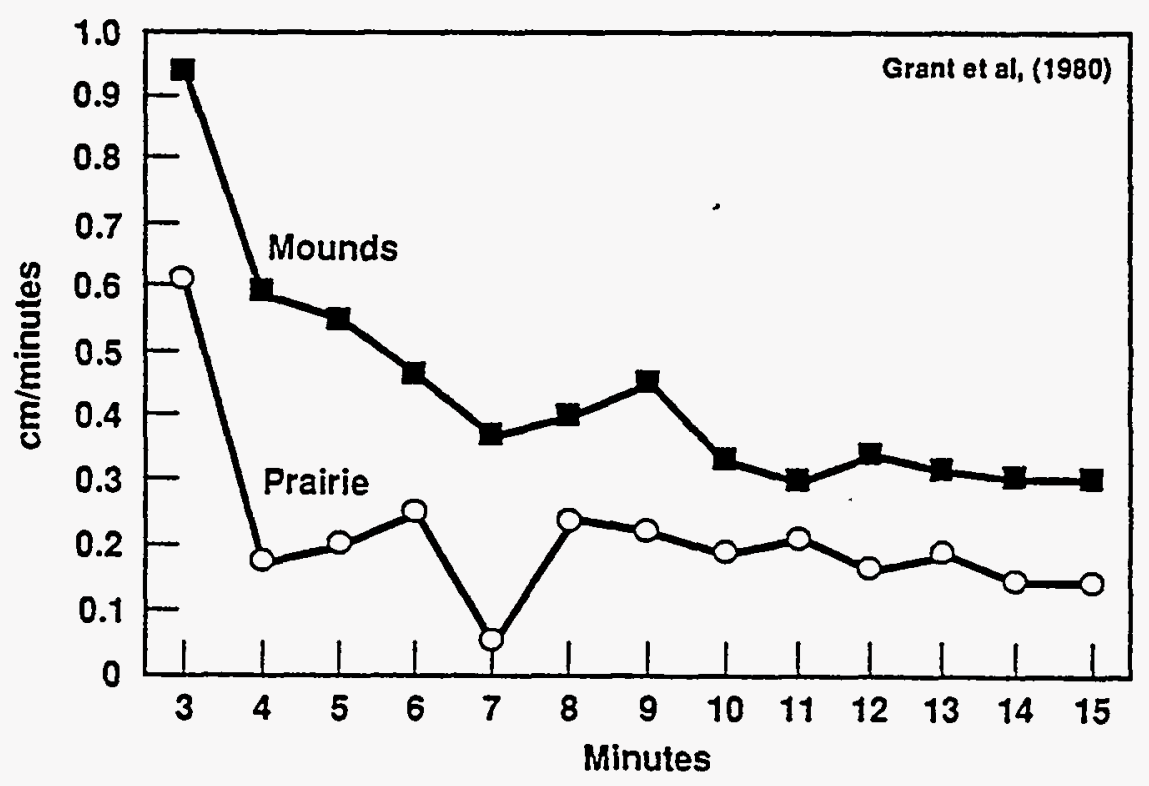

Figure 11. Average Volumetric Soil Water Contents for Pocket Gopher Mounds and Undisturbed Prairie Plots (time zero represents the termination of the experiment).

\section{Volumetric Soil Water Content Pocket Gopher Mounds}

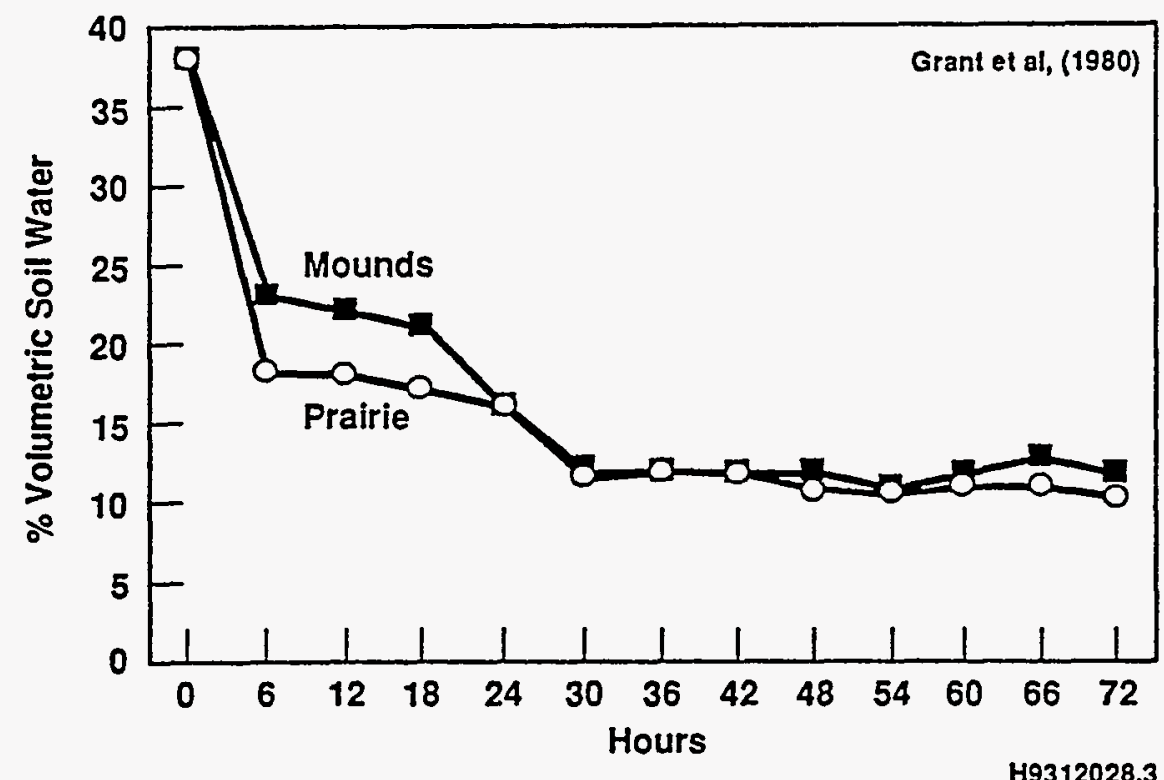




\subsection{HANFORD STUDY}

As previously mentioned, burrowing mammals will reside on any kind of protective barrier constructed. To address questions concerning the potential effects of burrowing mammals relative to water storage at the Hanford Site, an animal intrusion facility was constructed at the Hanford Meteorological Station (Figure 12). The objective of the study was to determine the degree that small mammal burrow systems affect the loss or retention of water at the Hanford Site.

\subsection{Construction}

Six animal lysimeters [ $5 \mathrm{ft}$ by $5 \mathrm{ft}$ by $6 \mathrm{ft}(1.5 \mathrm{~m}$ by $1.5 \mathrm{~m}$ by $1.8 \mathrm{~m})$ deep] and two outer boxes big enough to hold three lysimeters each were constructed in 1987 (Figure 12). The six individual animal lysimeters were designed so they could be disassembled and reused at the end of each test period (Photo 4). The outer boxes were installed in the ground at grade and buried approximately $100 \mathrm{ft}(92 \mathrm{~m})$ apart. At the beginning of each test the lysimeters were lined with a 28-mil plastic liner and filled with. McGee Ranch soil. The McGee Ranch is a fine-soil site that has been identified for protective barrier use (Last et al., 1987), near the intersection of State Highways 24 and 240 (Figure 13).

In tests 1 and 2, each lysimeter was filled with 6 to 8 in. $(15$ to $20 \mathrm{~cm}$ ) of pea gravel, with a geotextile material on top of the gravel. Four feet $(1.2 \mathrm{~m})$ of McGee Ranch soil was then added. In tests 3 through 5, the pea gravel and geotextile materials were not used. The soil was wet down and mixed before being placed in the lysimeters, allowing the soil to be compacted to facilitate animal burrowing. After the lysimeters were filled with soil, conductance probes (test 1 only) and two hydroprobe ports were installed in each lysimeter (tests 2 through 5). Soil core samples were collected at 6 -in. $(15-\mathrm{cm})$ intervals at the beginning and end of each test, and they were analyzed for soil

moisture content. Soil-moisture measurements also were collected at this time and during the test period with a neutron probe at 6 -in. $(15-\mathrm{cm})$ intervals in all lysimeters.

\subsection{Animals}

Small burrowing mammals common to the Hanford Site environs were selected for the study. The species selected are prolific burrowers and are common at the Hanford Site and throughout the Great Basin region of the western United States. These species will probably always reside at the Site. Even if the climate were to change drastically, there would always be small burrowing mammals at the Hanford Site similar to the species used in this study. 


\section{Animal Intrusion Lysimeter Facility}

\section{Experimental Design}

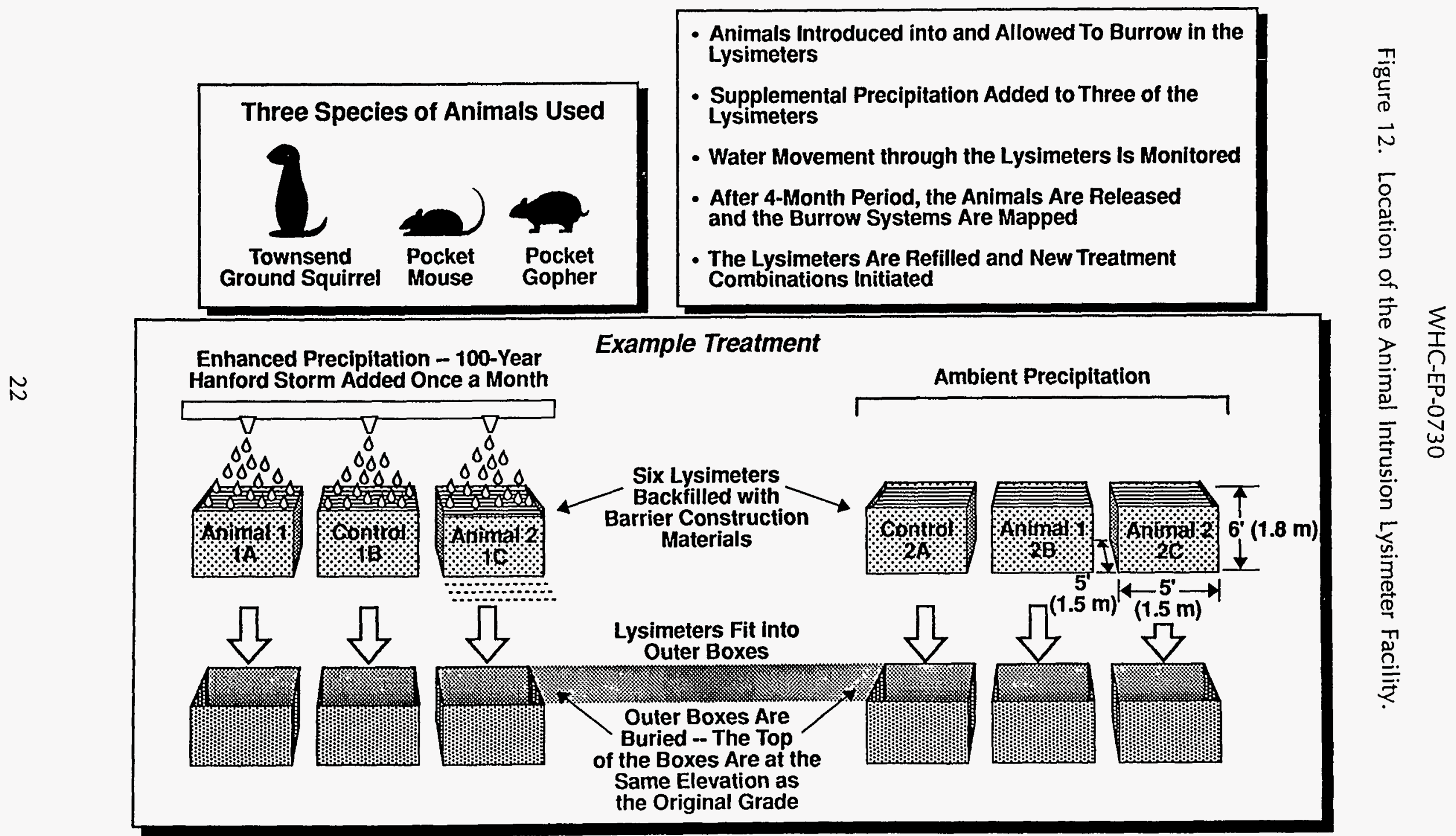

H9008010.20A 
Photo 4. Installation of an Animal Lysimeter.

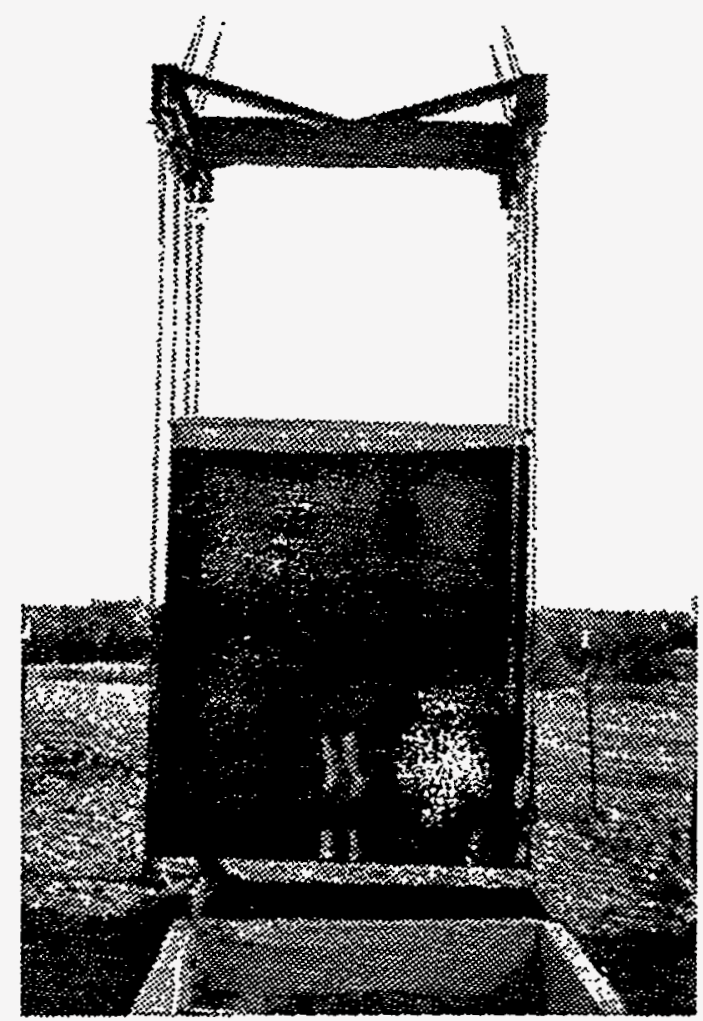

Photo 5. Townsend Ground Squirrel in Native Habitat at the Hanford Site.

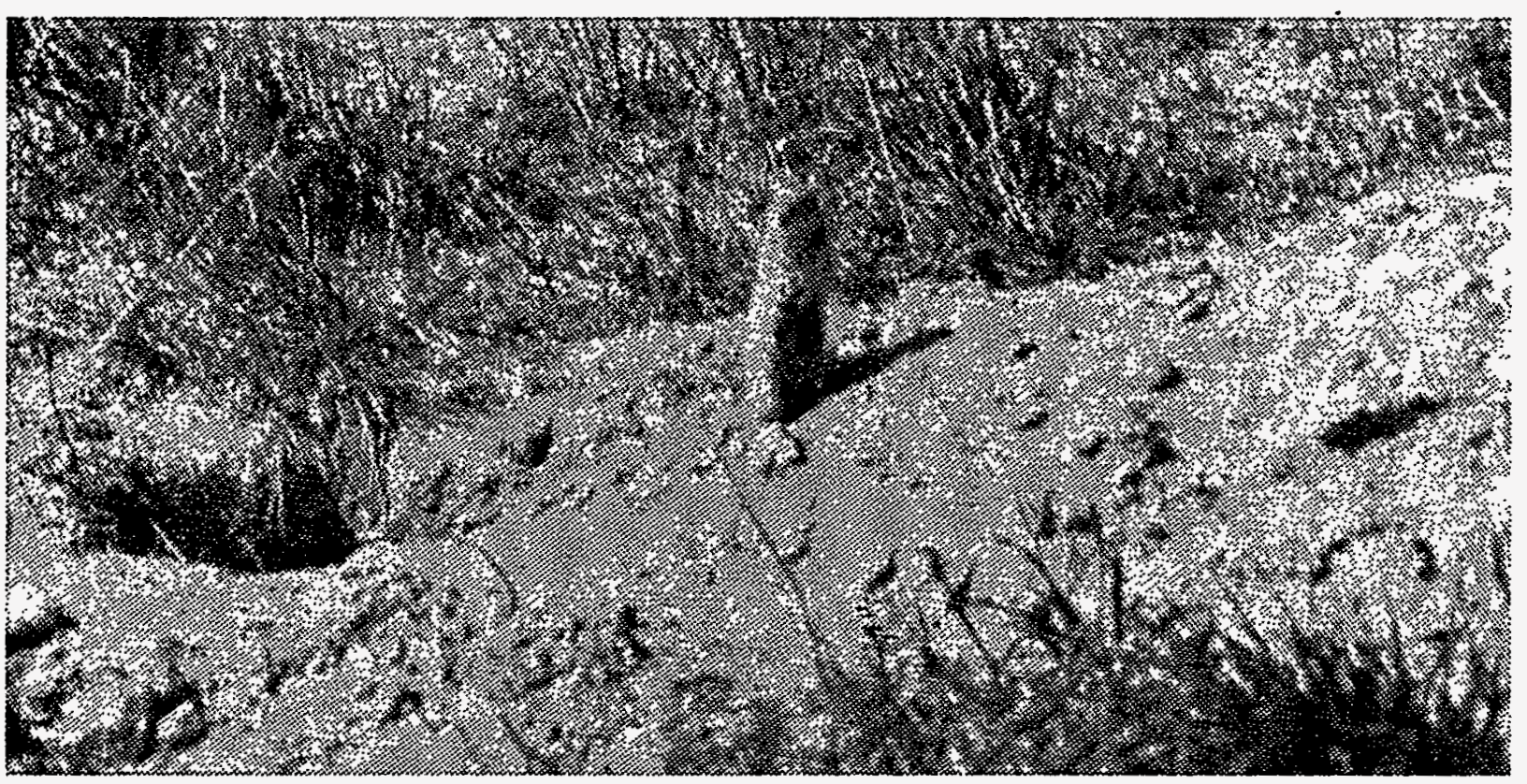


WHC-EP-0730

Figure 13. Experimental Design of the Small-Mammal Water Infiltration Study.

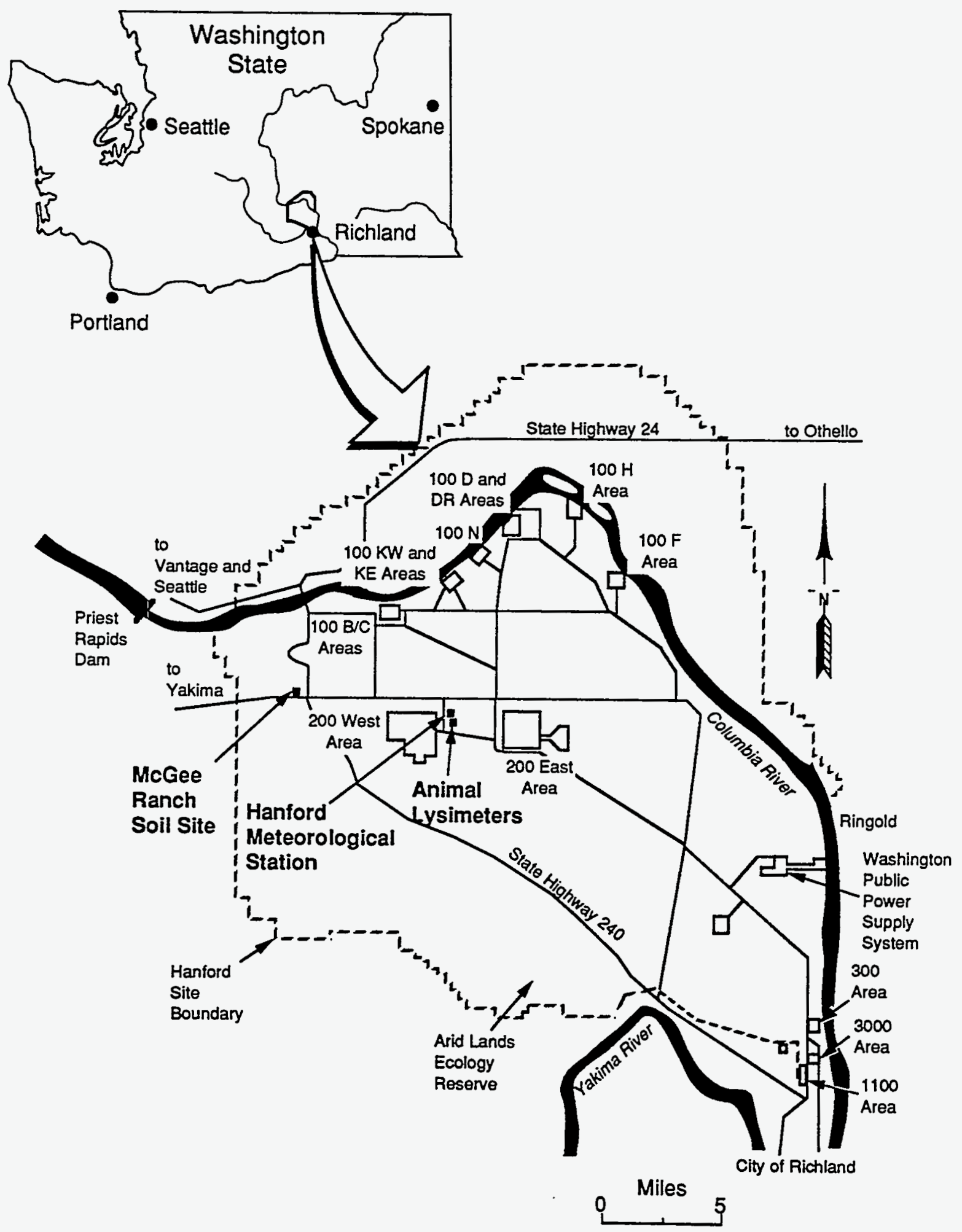

H9007012.1a 
Animals were live trapped with Sherman traps and placed in the lysimeters within 3 to 5 days of when the hydroprobe ports were installed. Test periods lasted 3 to 4 months. The three small mammals used in this study were the Great Basin pocket mouse (Perognathus parvus), the Northern pocket gopher (Thomomys talpoides), and the Townsend ground squirrel (Spermophilus townsendii).

Two species of animals were used per test, with one animal in each lysimeter. Two of the lysimeters served as controls during each test period (containing no animals). Small depressions were excavated with a trowel before the animals were placed into the lysimeter to encourage them to begin burrowing. Food and water were added liberally to each animal lysimeter throughout the course of the study. All lysimeters were covered with a hardware cloth screen to prevent the animals from escaping and to provide protection from predators. At the end of each test period, the animals were removed, and the lysimeters were removed and disassembled. When possible, burrow systems were excavated and mapped.

\subsubsection{Townsend Ground Squirrel}

Townsend ground squirrels are 180 to $240 \mathrm{~mm}$ long, weigh 160 to $252 \mathrm{~g}$, and reside in the sagebrush and grassland areas of southeastern Washington. They have short tails, and their bodies are smoke-gray washed with pinkish buff. Townsend ground squirrels are considered pests by the agricultural community because the squirrels feed on green vegetation. These squirrels are colonial and the burrow usually has a rim of dirt 4 to 6 in. (10 to $15 \mathrm{~cm}$ ) high around the burrow entrance (Photo 5). They become dormant in May/June, and they emerge January to March (Burt and Grossenheider, 1980).

\subsubsection{Great Basin Pocket Mouse}

Great Basin pocket mice are 140 to $176 \mathrm{~mm}$ long, including the tail. Adults weigh from 18 to $30 \mathrm{~g}$ and are olive-gray, usually washed with fulvous on the belly. Great Basin pocket mice can be found in the sagebrush, chaparral, pinon, and yellow pine habitats of Washington, Oregon, Idaho, Nevada, and California. They are the most common small burrowing mammal in sagebrush habitats of southeastern Washington (Photo 6). Generally this species is inactive in winter, when it survives on seed caches stored in the burrow and elsewhere (Burt and Grossenheider, 1980).

\subsubsection{Northern Pocket Gopher}

The northern pocket gopher is 127 to $165 \mathrm{~mm}$ long and weighs 75 to $130 \mathrm{gm}$. This gopher is grayish, sometimes washed with brown; the nose is brown or blackish (Photo 7). Northern pocket gophers are widespread in all the western states and many parts of Canada. Pocket gophers are active day and night throughout the year. In winter, they tunnel through snow and push loose dirt into tunnels. When snow melts, long ropelike cores of dirt settle to the surface (Photo 8). They are considered harmful wherever they appear in cultivated areas, especially alfalfa fields (Burt and Grossenheider, 1980). 
Photo 6. Great Basin Pocket Mouse in Native Habitat at the Hanford Site.

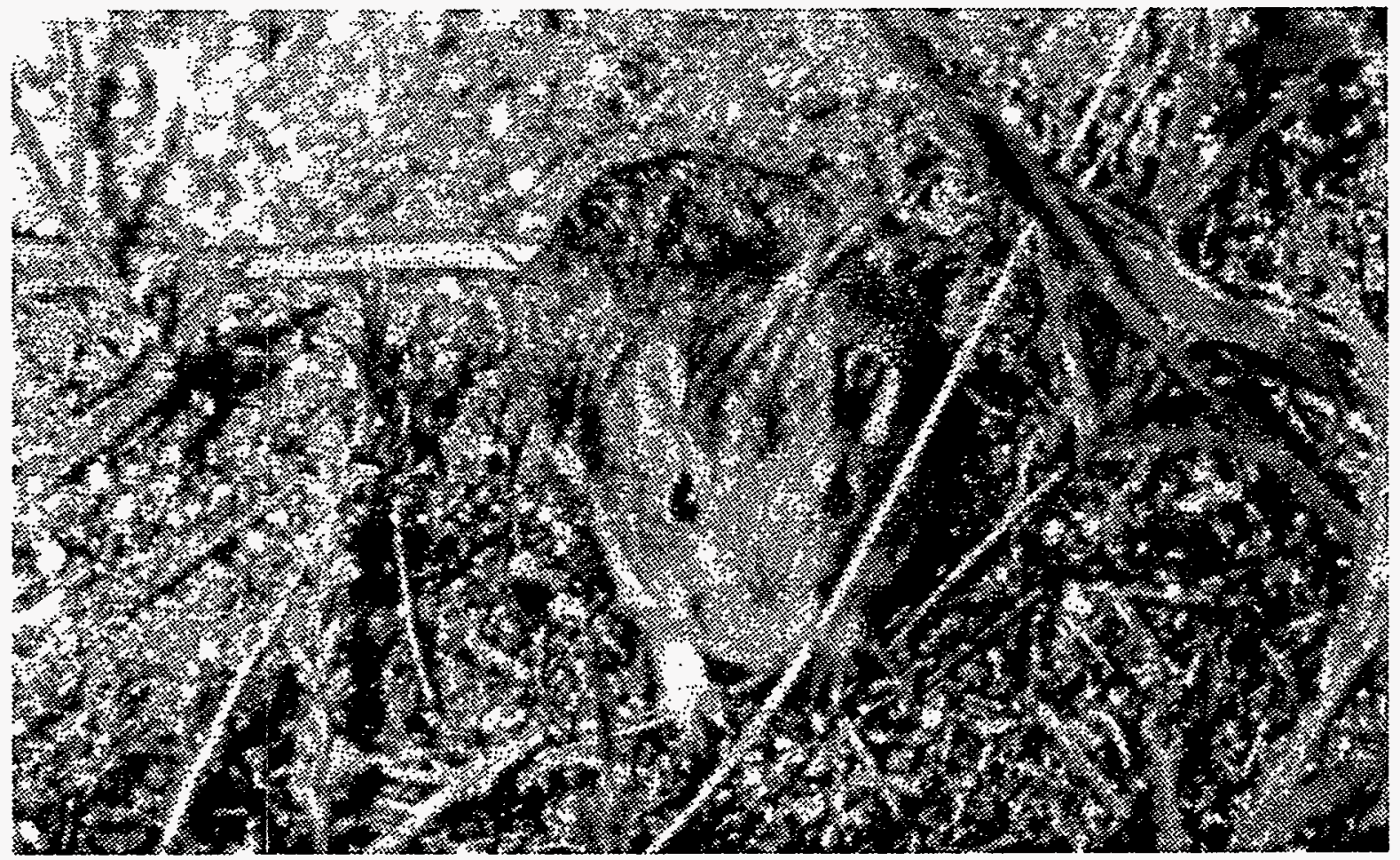

Photo 7. Northern Pocket Gopher Excavating a Burrow in a Lysimeter.

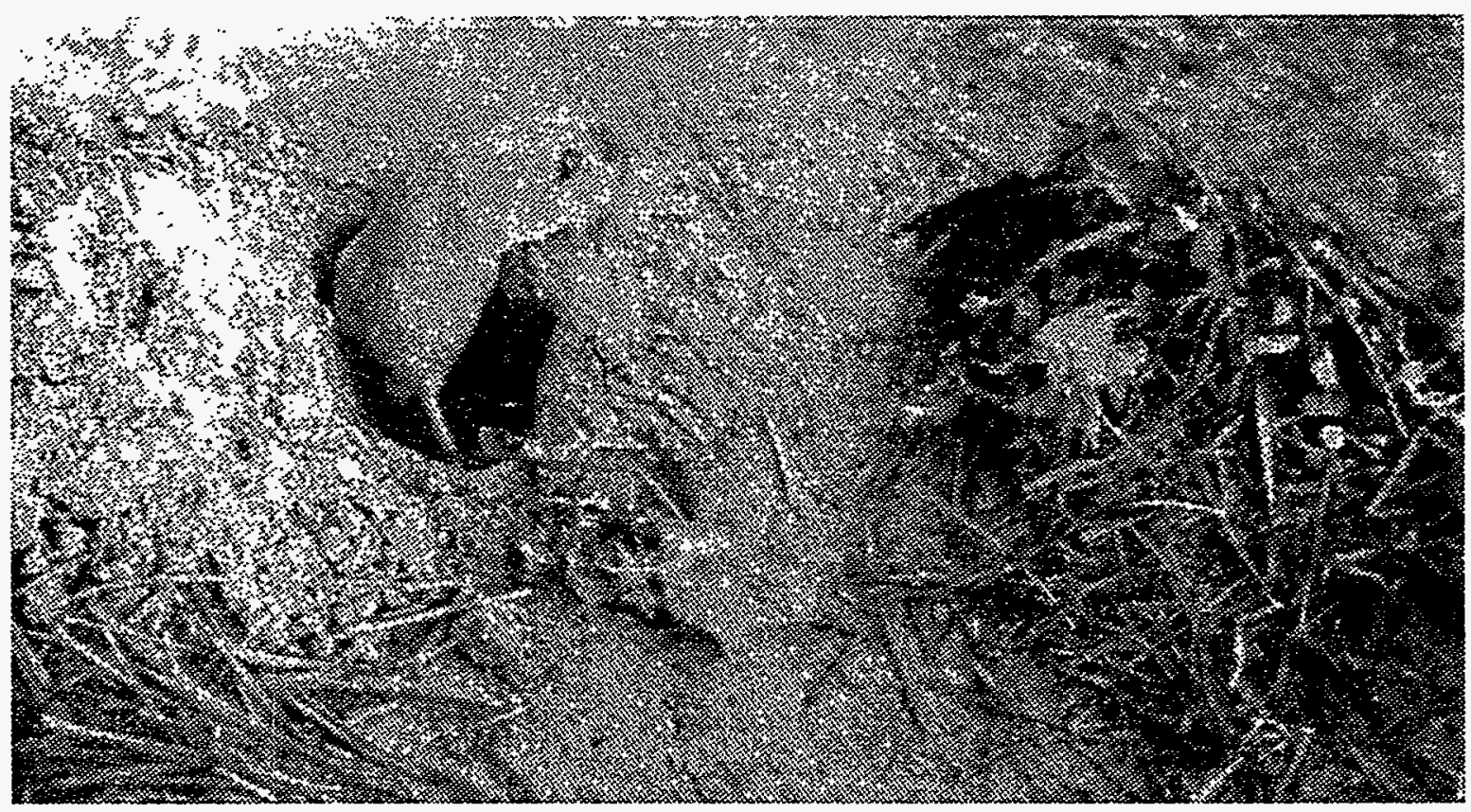




\subsection{Rainfall Simulator}

A rotating-boom rainfall simulator (i.e., rainulator), modified after Swanson (1965), was used to apply supplemental precipitation to boxes $1 \mathrm{~A}, 1 \mathrm{~B}$, and $1 \mathrm{C}$ on a monthly basis during each test period (Photo 9). Water was applied at an intensity of $2.5 \mathrm{in} . /$ hour $(6 \mathrm{~cm} / \mathrm{hour}$ ) for 13 minutes, which is the equivalent of the Hanford Site 100-yr storm (Stone et al., 1983). This adds $0.55 \mathrm{in} .(1.3 \mathrm{~cm})$ of water in 13 minutes. Applying supplemental precipitation at this rate several times during each test probably has not happened previously at the Hanford Site. To simulate overland flow and ponding effects, as much water as possible was applied during one precipitation event. Ponding and runoff effects were accomplished at the application rates mentioned previously.

\subsection{Soil Moisture Measurements}

In test 1, a method for soil moisture measurements was used that consisted of a conductivity probe (Gardner, 1986) fashioned with many electrodes evenly spaced along a wooden dowel, which was inserted into the soil. An alternating-current bridge was used to detect changes in electrical resistance of the soil beneath paired electrodes. Based on the results of test 1 , and concurrent studies by Cadwell et al. (1989), too many inconsistencies were noted in the conductance probe data and so, in all subsequent tests, neutron probes were used instead.

A neutron probe consists of a fast-neutron source, a slow-neutron detector, and a scaler (Campbell et al., 1990). The scaler counts the slow neutrons that have been slowed down and reflected back to the detector by the water in the soil. The number of slow neutrons measured is related to the amount of water present in the soil. Some inherent problems exist in interpreting the hydroprobe results and correlating those results to animal burrowing. The animals can create void spaces around the hydroprobe ports during burrowing activity, which can affect the integrity of the hydroprobe readings. Because of this potential problem, the hydroprobe data was only reviewed to indicate overall trends in soil moisture conditions (i.e., wetter or drier). 
Photo 8. Soil Cast From Pocket Gopher Burrowing Activity in the Winter.

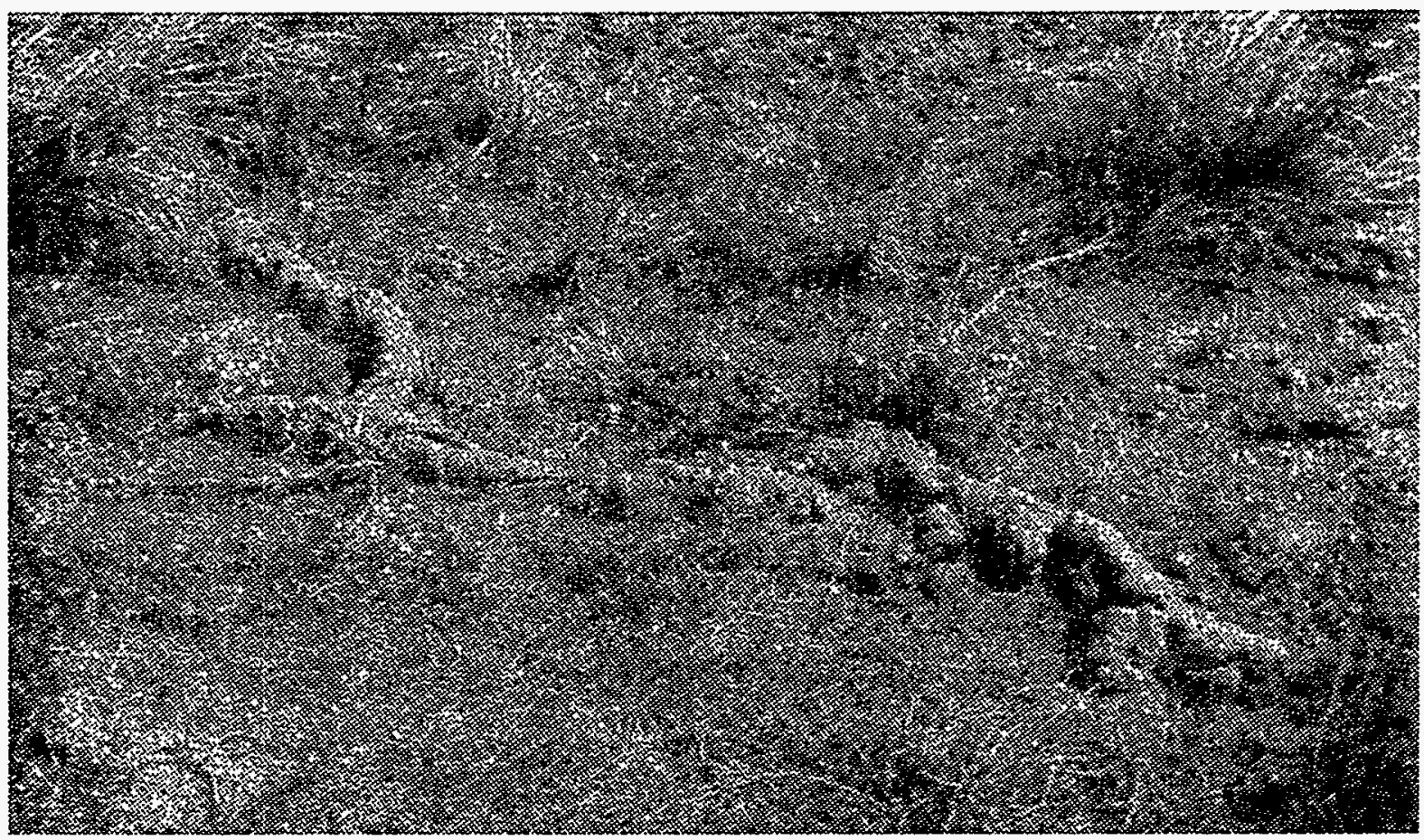

Photo 9. Rainfall Simulator Applying Precipitation to Three Lysimeters.

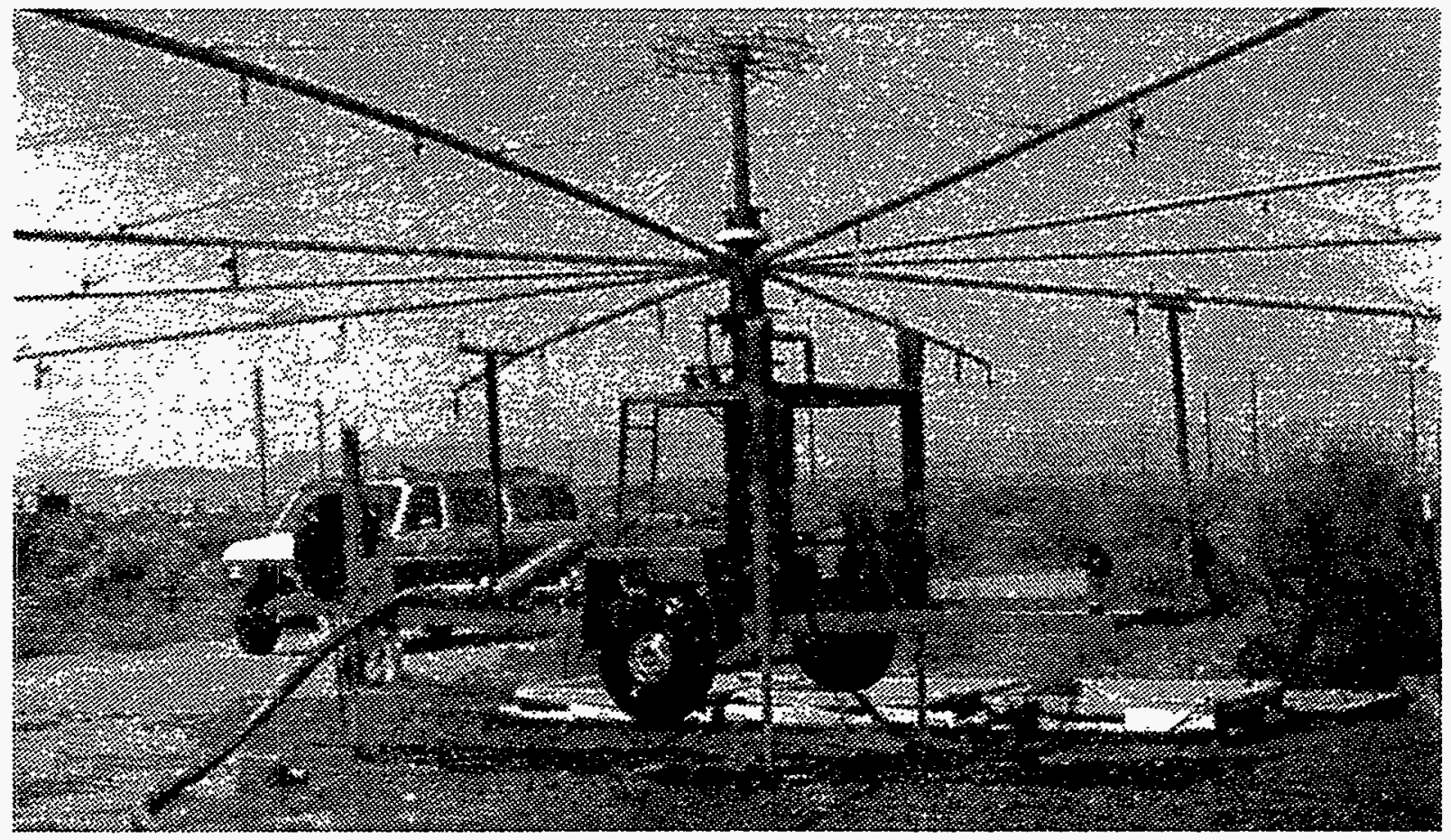




\subsection{RESULTS}

Appendices $A$ and $B$ contain the results of the soil moisture profile changes calculated from the gravimetric soil samples for all tests and the complete set of soil conductance and neutron probe readings. Graphs of soil moisture changes throughout each test were generated from the gravimetric soil sampling and are presented in Appendix C. Appendix D presents graphs that were generated using the neutron probe data.

\subsection{Test 1 (Summer Treatment)}

Test 1 was conducted from April 1988 to October 1988 with Great Basin pocket mice and Townsend ground squirrels (Table 1). Table 2 shows the soil moisture profile changes that were measured in test 1 and all other tests. Supplemental precipitation was applied three times during test 1 .

All of the lysimeters, including the two controls (which contain no animals), lost water in this test. Information from test 1 indicated that the $1.65 \mathrm{in} .(4.2 \mathrm{~cm})$ of supplemental precipitation applied with the rainulator to the lysimeters with animals was removed. The water in the soils of the lysimeters (even those lysimeters receiving supplemental precipitation) was not being stored, but was evaporating. The data did not indicate a significant difference in the water contents of the soils at depth in the lysimeters with animal burrows, compared with the water content of soils at depth in the control lysimeters, which did not have animal burrows.

Figure 14 compares a pocket mouse and a control lysimeter that had both received supplemental precipitation. The pocket mouse plot started with $19.84 \%$ moisture and ended up with $9.64 \%$ moisture (a net loss of $11.27 \%$ ). The control plot started with $17.36 \%$ moisture and ended up with $10.92 \%$ (a net loss of $6.44 \%$ ). The pocket mouse plot lost $4.8 \%$ more moisture than the control. No difference existed between the control (no animal) lysimeter and a Townsend ground squirrel lysimeter that had both received supplemental precipitation. Both of these lysimeters had a net moisture loss of $6.44 \%$. The three lysimeters, including the control (containing no animal) that did not receive supplemental precipitation, had ending soil moisture values between 8 and $8.5 \%$. This indicates that the data did not show any obvious effects on water storage as a result of animal burrowing.

The pocket mouse in lysimeter $1 \mathrm{~A}$ penetrated the geotextile layer without any problem and some of the pea gravel had been removed to some of the upper tunnels. Soil moisture measurements were not taken in the pea gravel. There was no visible evidence of water in the pea gravel in any of the lysimeters. 
Table 1. Individual Lysimeters and Species Assignments Presented for all Five Tests.

\begin{tabular}{|c|c|c|c|}
\hline $\begin{array}{c}\text { Test } \\
\text { Number }\end{array}$ & Description & Lysimeter & Species \\
\hline One & \begin{tabular}{|c|} 
Summer \\
April 88 - Oct. 88
\end{tabular} & $\begin{array}{l}1 A^{*} \\
1 B^{*} \\
1 C^{*} \\
2 A \\
2 B \\
2 C\end{array}$ & $\begin{array}{c}\text { Pocket Mouse } \\
\text { Control } \\
\text { Townsend Ground Squirrel } \\
\text { Control } \\
\text { Townsend Ground Squirrel } \\
\text { Pocket Mouse }\end{array}$ \\
\hline Two & $\begin{array}{c}\text { Winter } \\
\text { Nov } 88 \text { - April } 89\end{array}$ & $\begin{array}{l}1 A \\
1 C \\
2 A \\
2 B \\
2 C\end{array}$ & $\begin{array}{l}\text { Pocket Gopher } \\
\text { Control } \\
\text { Pocket Mouse } \\
\text { Pocket Gopher } \\
\text { Control } \\
\text { Pocket Gopher }\end{array}$ \\
\hline Three & \begin{tabular}{|c|} 
Summer \\
May $89-$ Aug 89
\end{tabular} & $\begin{array}{l}1 A^{*} \\
1 B^{*} \\
1 C^{*} \\
2 A \\
2 B \\
2 C\end{array}$ & $\begin{array}{l}\text { Townsend Ground Squirrel } \\
\text { Pocket Gopher } \\
\text { Control } \\
\text { Townsend Ground Squirrel } \\
\text { Pocket Gopher } \\
\text { Control }\end{array}$ \\
\hline Four & $\begin{array}{c}\text { Winter } \\
\text { Oct } 89-\text { Feb } 90\end{array}$ & $\begin{array}{l}1 A^{*} \\
1 B^{*} \\
1 C^{*} \\
2 A \\
2 B \\
2 C\end{array}$ & $\begin{array}{l}\text { Pocket Gopher } \\
\text { Pocket Mouse } \\
\text { Control } \\
\text { Pocket Mouse } \\
\text { Pocket Gopher } \\
\text { Control }\end{array}$ \\
\hline Five & $\begin{array}{c}\text { Summer } \\
\text { April } 90 \text { - Aug } 90\end{array}$ & $\begin{array}{l}1 A^{*} \\
1 B^{2} \\
1 C^{*} \\
2 A \\
2 B \\
2 C\end{array}$ & $\begin{array}{c}\text { Townsend Ground Squirrel } \\
\text { Pocket Mouse } \\
\text { Control } \\
\text { Townsend Ground Squirrel } \\
\text { Pocket Mouse } \\
\text { Control }\end{array}$ \\
\hline
\end{tabular}

"Supplemental precipitation added with rainulator 
Table 2. Summary of Overall Soil Moisture Changes Calculated from Soil Sample Collected at the Beginning and End of Each Test Period.

\begin{tabular}{|c|c|c|c|c|c|c|}
\hline $\begin{array}{c}\text { Test } \\
\text { Number }\end{array}$ & $\begin{array}{l}\text { Box ID } \\
\text { Number }\end{array}$ & Species & $\begin{array}{l}\text { Rainulator } \\
\text { (Yes or No) }\end{array}$ & $\begin{array}{c}\text { Initial } \\
\text { Moisture \% }\end{array}$ & $\begin{array}{c}\text { Ending } \\
\text { Moisture } \\
\%^{\mathrm{a}}\end{array}$ & Change \% \\
\hline \multicolumn{7}{|c|}{ Summer, April 88 - October 88} \\
\hline 1 & $\overline{1 A}$ & P. mouse & Yes & 16.55 & 8.85 & -7.70 \\
\hline 1 & TB & Control & Yes & 14.78 & -4.94 & -4.94 \\
\hline 1 & $1 \mathrm{C}$ & Townsend & Yes & 14.77 & 9.83 & -4.94 \\
\hline 1 & $2 \mathrm{~A}$ & Control & No & 13.90 & -5.55 & -5.55 \\
\hline 1 & $2 B$ & Townsend & No & 13.51 & 8.33 & -5.18 \\
\hline 1 & $2 \mathrm{C}$ & P. mouse & No & 11.97 & -3.53 & -3.53 \\
\hline \multicolumn{7}{|c|}{ Winter, November 88 - April 89} \\
\hline 2 & $1 \mathrm{~A}$ & P. gopher & No & 8.99 & 10.44 & +1.55 \\
\hline 2 & 1B & Control & No & 8.68 & 10.04 & +1.39 \\
\hline 2 & $1 C$ & P. mouse & No & 8.82 & 11.02 & +2.20 \\
\hline 2 & $2 \mathrm{~A}$ & P. gopher & No & 7.85 & 10.93 & +3.08 \\
\hline 2 & $2 B$ & Control & No & 9.04 & 10.48 & +1.44 \\
\hline 2 & $2 C$ & P. gopher & No & 8.11 & 10.71 & +2.60 \\
\hline \multicolumn{7}{|c|}{ Summer, May 89 - August 89} \\
\hline 3 & $\overline{1 A}$ & Townsend & Yes & 14.25 & 10.59 & -3.67 \\
\hline 3 & 1B & P. gopher & Yes & 13.85 & 10.65 & -3.19 \\
\hline 3 & $1 \mathrm{C}$ & Control & Yes & 14.73 & 10.92 & -3.81 \\
\hline 3 & $2 A$ & Townsend & No & 13.86 & 8.60 & -5.26 \\
\hline 3 & $2 B$ & P. gopher & No & 14.42 & 8.40 & -6.03 \\
\hline 3 & $2 C$ & Control & No & 14.37 & 9.52 & -4.85 \\
\hline \multicolumn{7}{|c|}{ Winter, October 89 - February 90} \\
\hline 4 & $\overline{1 A}$ & P. gopher & Yes & 9.14 & 10.25 & +1.11 \\
\hline 4 & 1B & P. mouse & Yes & 8.59 & 10.17 & +1.58 \\
\hline 4 & $1 \mathrm{C}$ & Control & Yes & 10.92 & 12.58 & +1.66 \\
\hline 4 & $2 A$ & P. gopher & No & 11.05 & 10.64 & +0.41 \\
\hline 4 & $2 B$ & P. gopher & No & 9.99 & 10.95 & +0.96 \\
\hline 4 & $2 \mathrm{C}$ & Control & No & 9.52 & 11.41 & +1.89 \\
\hline \multicolumn{7}{|c|}{ Summer, April 90 - August 90} \\
\hline 5 & $\overline{1 A}$ & Townsend & Yes & 13.17 & 9.02 & -2.89 \\
\hline 5 & 1B & P. mouse & Yes & 12.83 & 9.03 & -3.80 \\
\hline 5 & $1 C$ & Control & Yes & 13.68 & 9.26 & -4.42 \\
\hline 5 & $2 A$ & Townsend & No & 11.88 & 6.76 & -5.12 \\
\hline 5 & $2 B$ & P. mouse & No & 12.01 & 8.42 & -3.59 \\
\hline 5 & $2 C$ & Control & No & 12.13 & 8.18 & -3.59 \\
\hline
\end{tabular}

${ }^{a}$ Average soil moisture from core samples in soil only, initial water contents are averages of 2 samples' depth; ending moisture contents are single samples 
Figure 14. Soil Moisture Profile Changes Measured in Test 1 (a lysimeter containing a pocket mouse and a control lysimeter with added supplemental precipitation).

\section{Soil Moisture Profile Changes (Test 1) With Supplemental Precipitation}

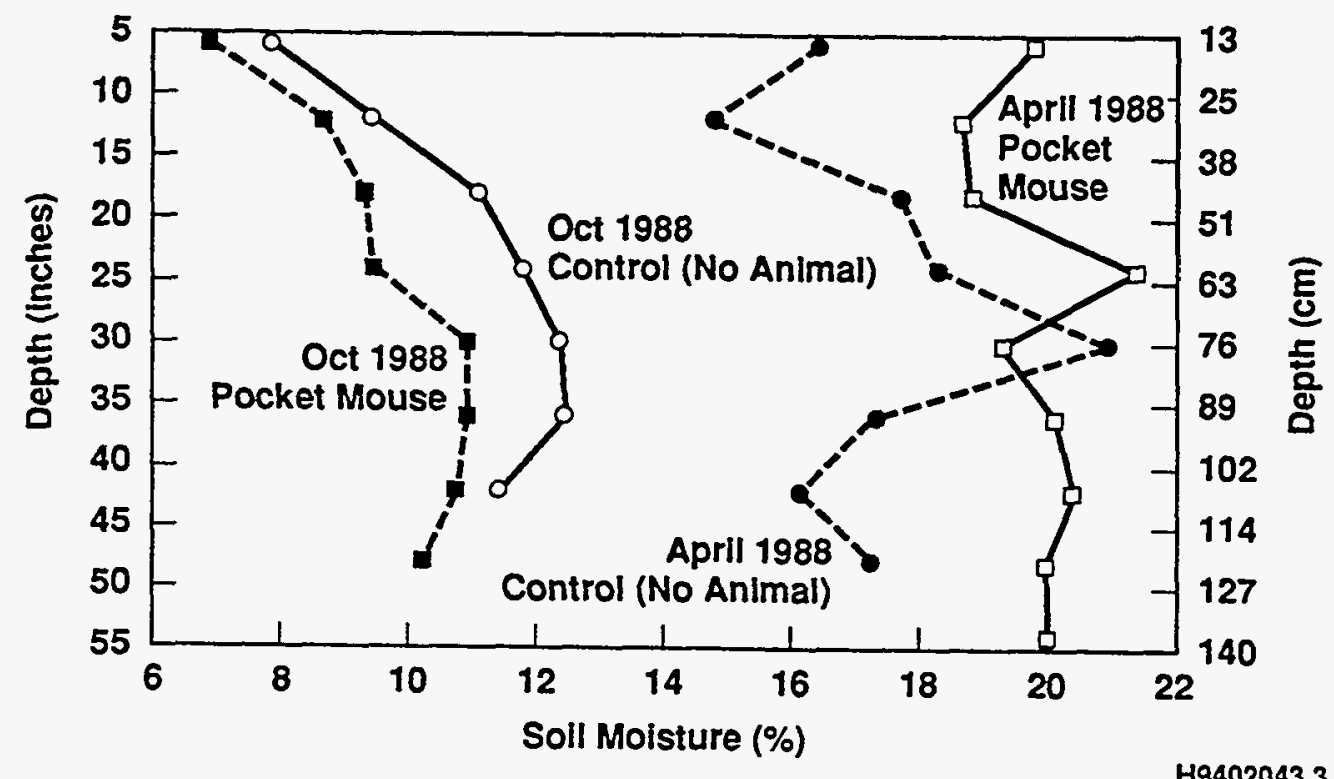

\subsection{Test 2 (Winter Treatment)}

Test 2 was conducted from November 1988 to April 1989 using Great Basin pocket mice and pocket gophers (Table 1). Table 2 shows the soil moisture profile changes measured in test 2 .

Frozen soil conditions and frozen water lines during test 2 prevented the addition of supplemental precipitation. However, 4.14 in. $(10.5 \mathrm{~cm})$ of supplemental precipitation was added in the form of natural precipitation (rain and snow) that, according to the Hanford Meteorological Station, was $178 \%$ of normal by the end of March.

Test 2 provided a good comparison of soil moisture conditions under natural precipitation conditions during the winter season. All six lysimeters had a net increase in soil moisture (Table 1). The largest increases in soil moisture in all the lysimeters occurred from 18 to 30 in. $(46$ to $76 \mathrm{~cm})$ with the 18 in. $(46 \mathrm{~cm})$ depth showing the most change. The least amount of change in soil moisture occurred from the 42- to 48-in. (107- to 122-cm) depth. This is illustrated in Figure 15, which shows initial soil moisture conditions at the beginning and at the end of test 2 in a pocket mouse lysimeter and a control lysimeter. 
Figure 15. Soil Moisture Profile Changes Measured in Test 2

(a lysimeter containing a pocket mouse and a control lysimeter with ambient precipitation).

\section{Soil Moisture Profile Changes (Test 2) Ambient Precipitation (Winter)}

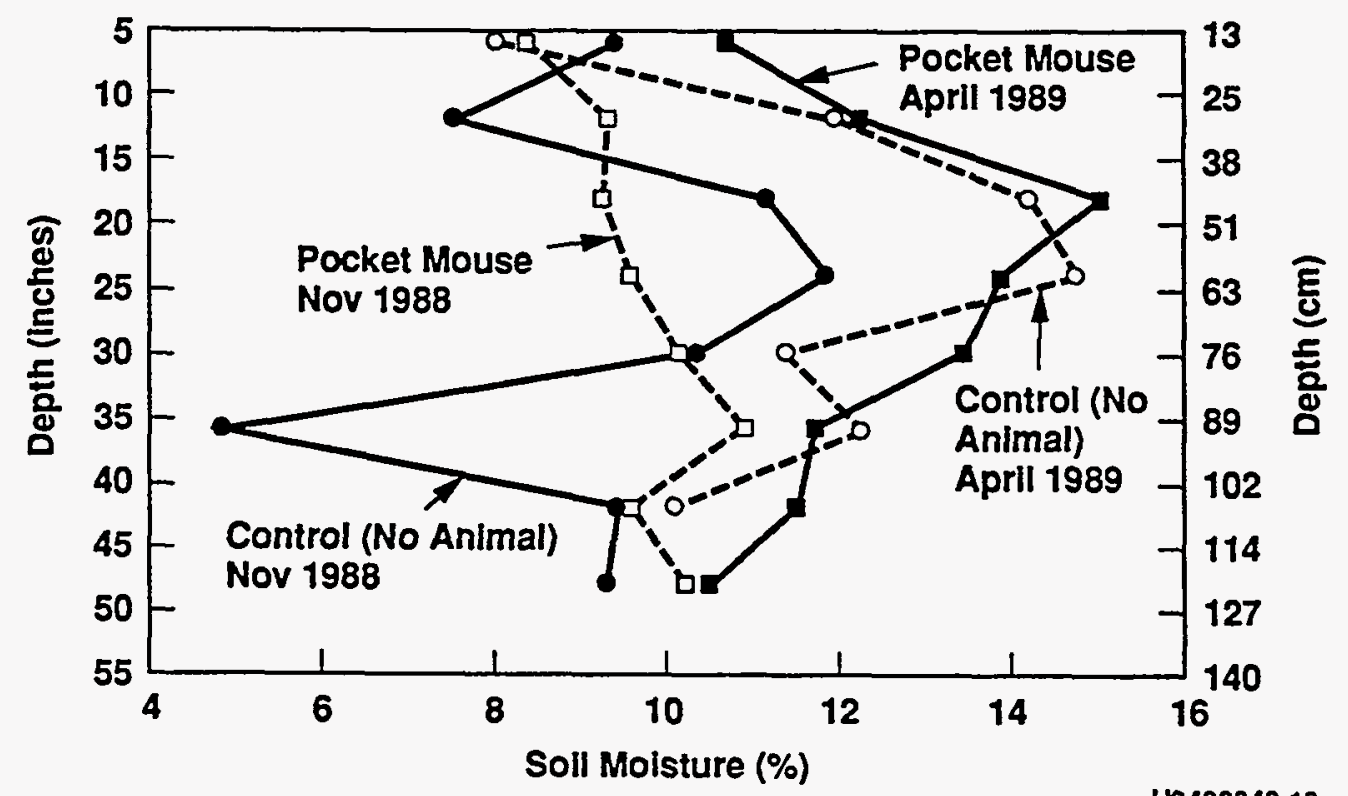

19402043.18

Hydroprobe readings from test 2 also confirm increasing soil moisture conditions in all six lysimeters during the test period. Figures 16 and 17 show this trend for a pocket gopher and a control lysimeter. The hydroprobe readings also indicate little change in soil moisture conditions below 30 in. $(76 \mathrm{~cm})$.

The pocket mouse in lysimeter $1 \mathrm{~A}$ and the pocket gophers in lysimeters $2 \mathrm{~A}$ and $2 \mathrm{C}$ penetrated the geotextile layer without any problem and some of the pea gravel had been removed to some of the upper tunnels. Soil moisture measurements were not taken in the pea gravel. There was no visible evidence of water in the pea gravel. Pea gravel and the geotextile material were placed in the lysimeters to see if these materials would act as a barrier to burrowing. The results from the first two tests showed that the geotextile material was not a deterrent to burrowing, so the pea gravel and geotextile material were not used in subsequent tests.

\subsection{Test 3 (Summer Treatment)}

Test 3 was conducted from May 1989 to August 1989 using Townsend ground squirrels and pocket gophers (Table 1). Table 2 presents the soil moisture profile changes that occurred during test 3 . Supplemental precipitation was added with the rainulator three times during test 3 . 
Figure 16. Hydroprobe Measurements Observed in Test 2

(a lysimeter containing a pocket gopher and no supplemental precipitation).

\section{Hydroprobe Readings (Test 2) \\ Pocket Gopher (No Supplemental Precipitation)}

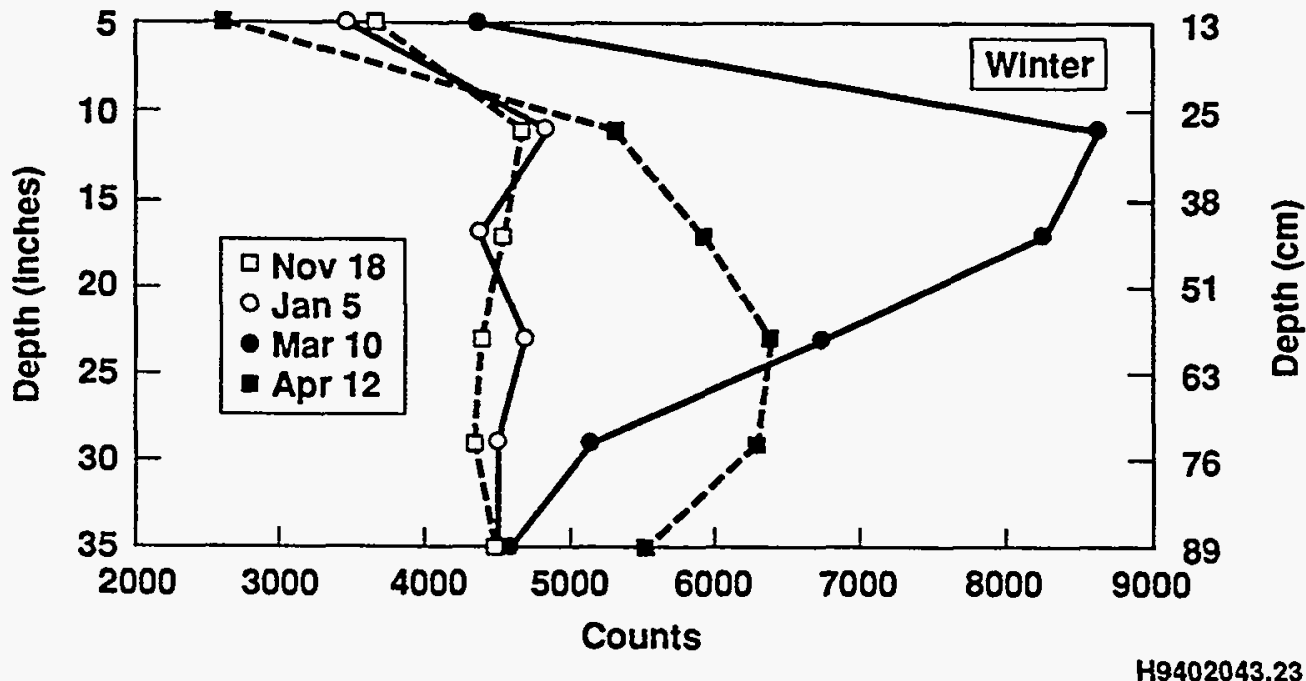

Figure 17. Hydroprobe Measurements Observed in Test 2

(a control lysimeter and no supplemental precipitation).

Hydroprobe Readings (Test 2) Control (No Animal) No Supplemental Precipitation

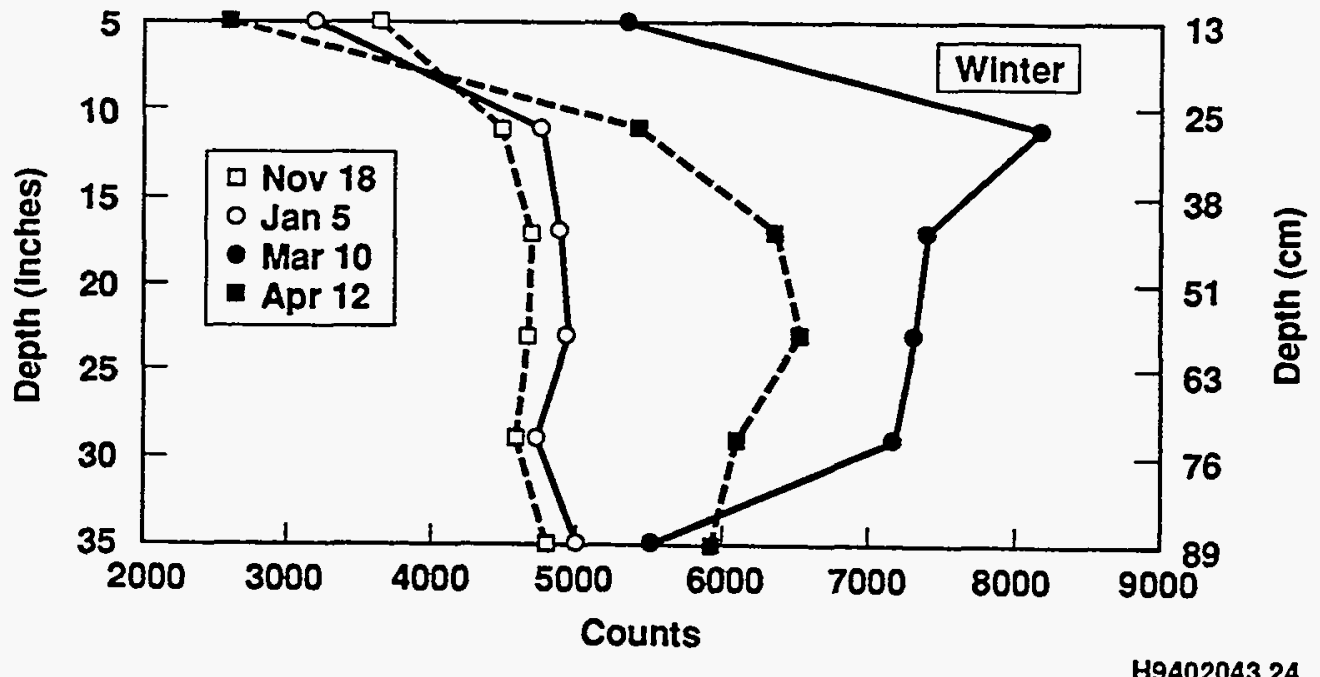


Data collected from test 3 indicated that all of the lysimeters lost water. As in test 1 , the 1.65 in. $(4.2 \mathrm{~cm})$ of supplemental precipitation, which was applied with the rainulator to three of the lysimeters, was removed. An example of this is shown in Figure 18 with the three lysimeters that received supplemental precipitation. The soil moisture graphs (Appendix C) do not indicate which lysimeters contained animals and which lysimeters served as the controls (containing no animals). As in test 1, any obvious effects of water storage in regards to animal burrowing was not observed.

The hydroprobe readings that were observed during test 3 also show the same overall trend of moisture loss. Figure 19 illustrates this point with a lysimeter that contained a pocket gopher and supplemental precipitation. The overall trend depicted in Figure 6 is less water accounted for at all depths during the test.

\subsection{Test 4 (Winter Treatment)}

Test 4, using pocket gophers and pocket mice, was started in October 1989 and ended in February 1990 (Table 1). Table 2 presents the soil moisture profile changes recorded during test 4 . Supplemental precipitation [1.10 in. $(2.8 \mathrm{~cm})]$ was added with the rainulator two times during test 4 . This was in addition to the $2.63 \mathrm{in} .(6.7 \mathrm{~cm})$ of natural precipitation (rain and snow) that was recorded during the test period.

According to the gravimetric soil moisture data calculated from soil cores, all of the lysimeters, except $2 \mathrm{~A}$, gained water. Lysimeter $2 \mathrm{~A}$, which contained a pocket gopher with no supplemental precipitation added, lost $0.61 \%$ overall moisture during test 4 . However, the hydroprobe data from lysimeter $2 \mathrm{~A}$ and all other lysimeters indicated a

Figure 18. Soil Moisture Profile Changes Measured in Test 3 (a lysimeter with added supplemental precipitation).

\section{Soil Moisture Profile Changes (Test 3) With Supplemental Precipitation}

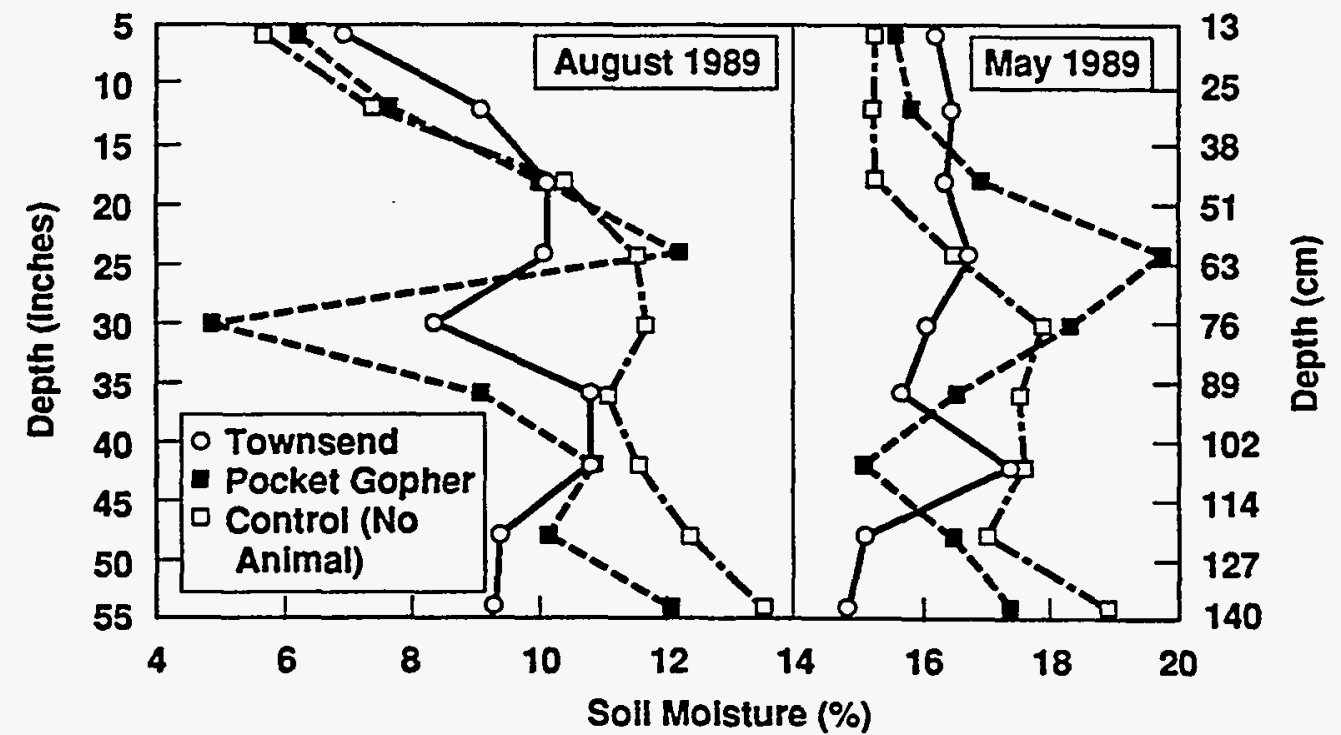

H9402043.61 
Figure 19. Hydroprobe Measurements Observed in Test 3

(a lysimeter containing a pocket gopher and added supplemental precipitation).

\section{Hydroprobe Readings (Test 3) Pocket Gopher (With Supplemental Precipitation)}

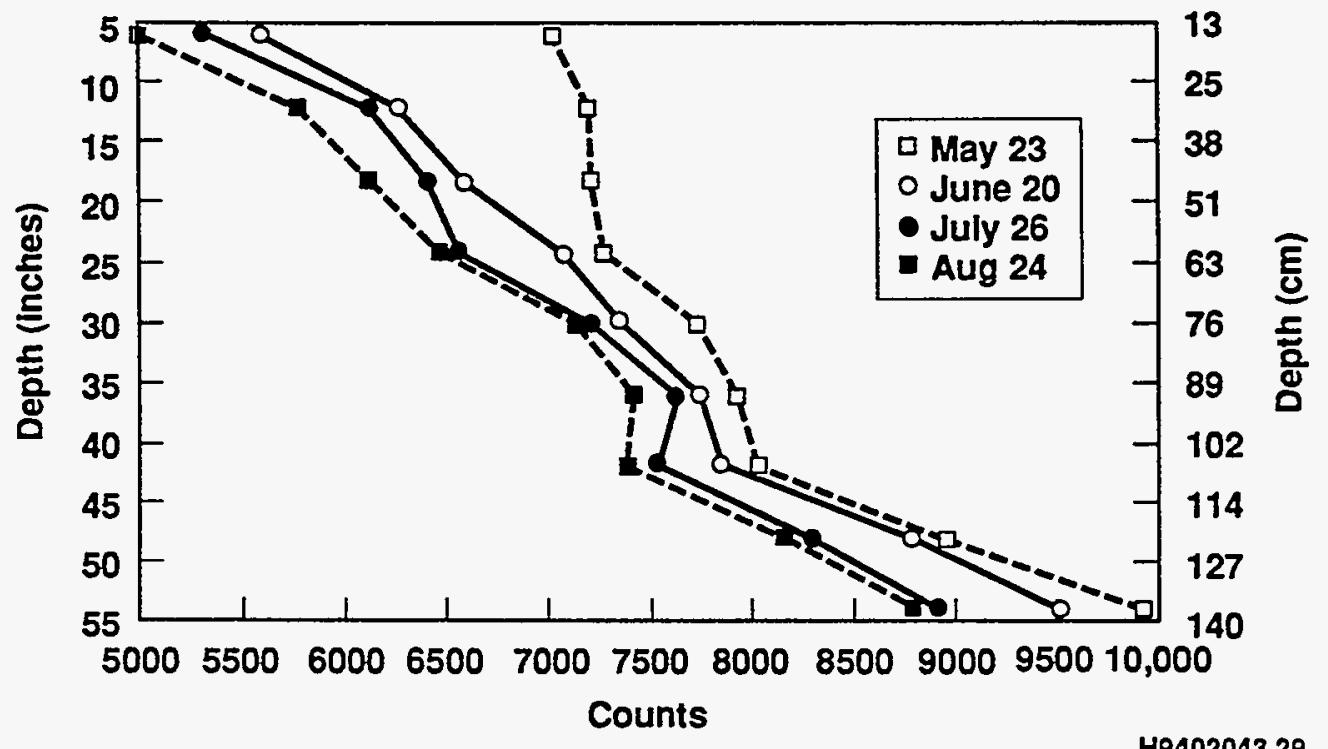

gain in soil moisture during test 4 . For some unexplained reason, the gravimetric soil moisture results from lysimeter $2 \mathrm{~A}$ are not consistent with the gravimetric results from the other five lysimeters in test 4 nor the gravimetric results from test 2 , which also was conducted in the winter.

An example of the overall increase in soil moisture observed during test 4 is shown in Figure 20 (a lysimeter with pocket gopher and supplemental precipitation). The two control plots, $1 \mathrm{C}$ (supplemental precipitation added) and $2 \mathrm{C}$ (no water added), gained the most water (Figures 5, 21, and 22, respectively).

The hydroprobe readings from all six lysimeters in test 4 also show the trend of increasing soil moisture conditions. An example of this is shown in Figures 21 and 22 [lysimeters containing a pocket mouse and supplemental precipitation (1B) and a pocket mouse and no supplemental precipitation (2B)]. Both graphs show increasing moisture conditions over time and that very little change in soil moisture occurred below 18 in. $(46 \mathrm{~cm})$. 
Figure 20. Soil Moisture Profile Changes Measured in Test 4 (a lysimeter containing a pocket gopher and added supplemental precipitation).

\section{Soil Moisture Profile Changes (Test 4) Pocket Gopher (With Supplemental Precipitation)}

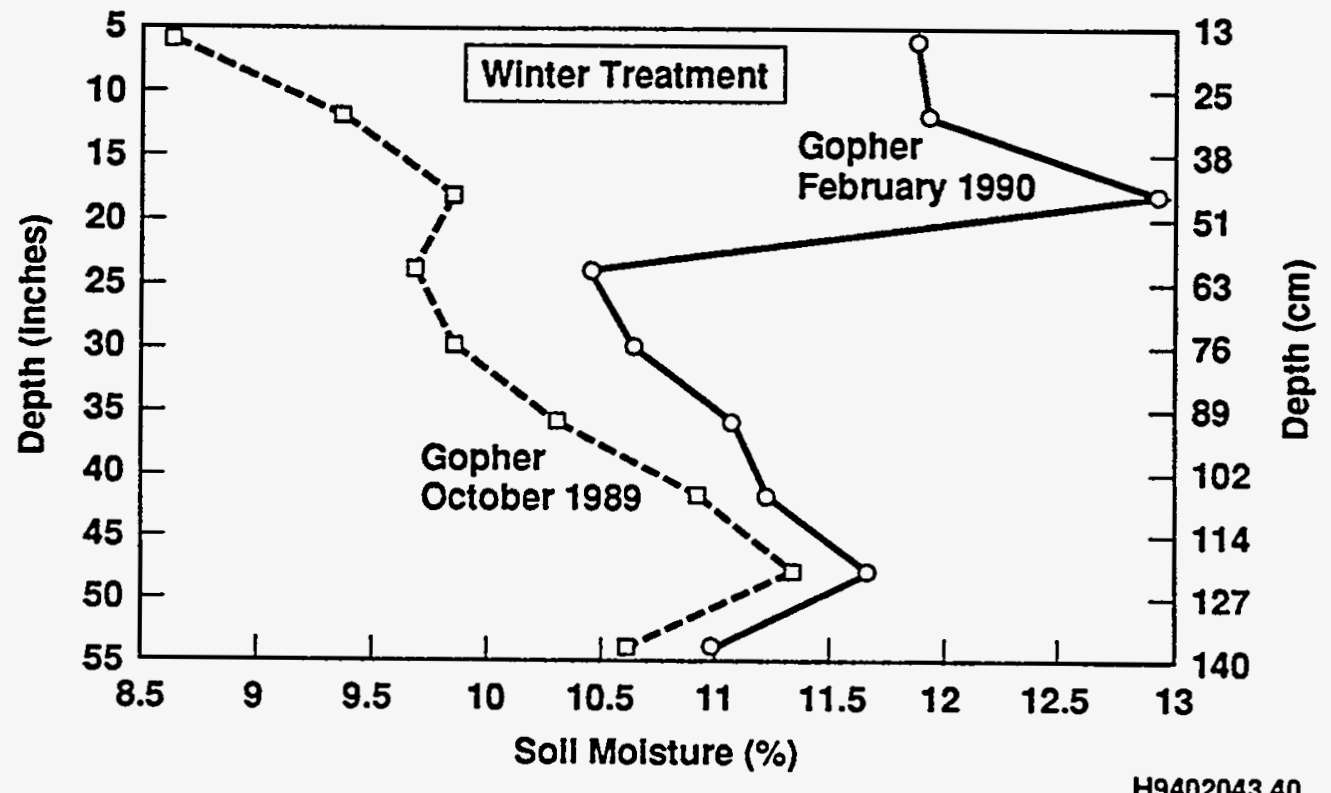

Figure 21. Hydroprobe Measurements Observed in Test 4

(a lysimeter containing a pocket mouse and added supplemental precipitation).

Hydroprobe Readings (Test 4) Pocket Mouse (With Supplemental Precipitation)

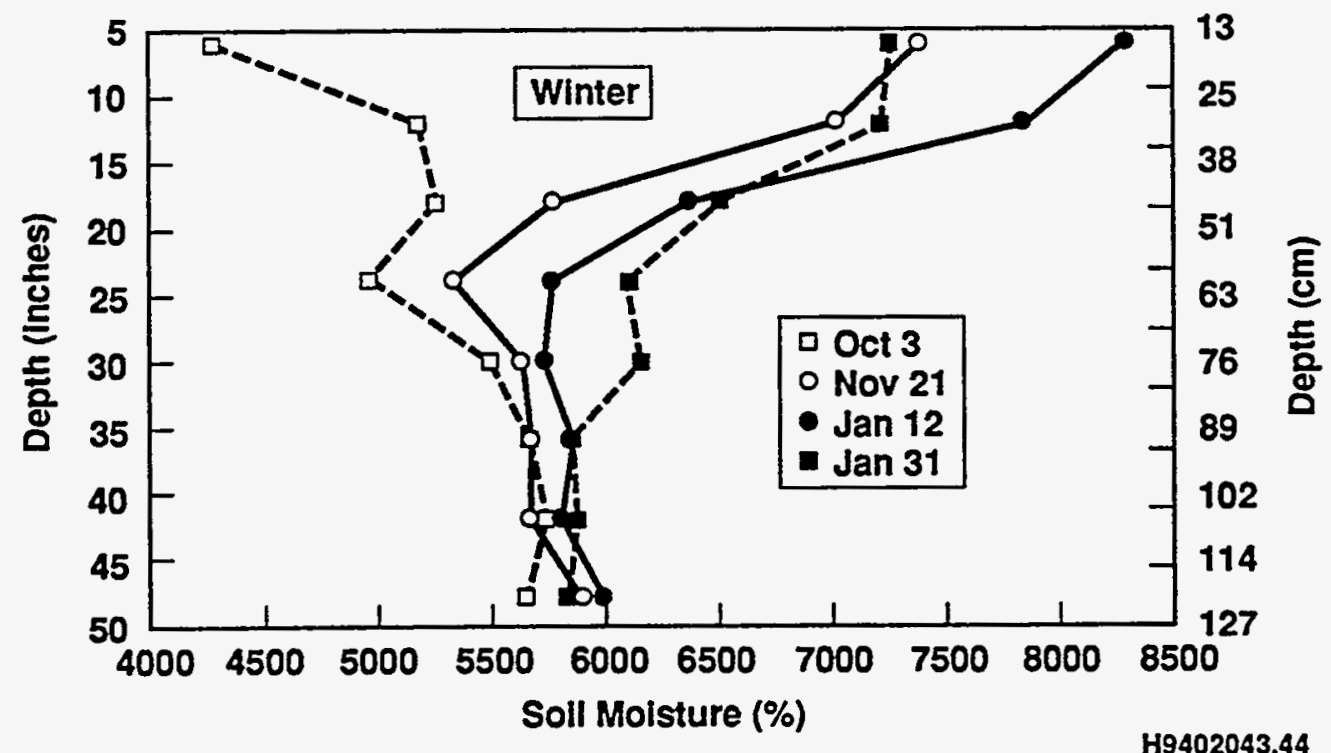


Figure 22. Hydroprobe Measurements Observed in Test 4 (a lysimeter containing a pocket mouse and no supplemental precipitation).

\section{Hydroprobe Readings (Test 4) Pocket Mouse (With No Supplemental Precipitation)}

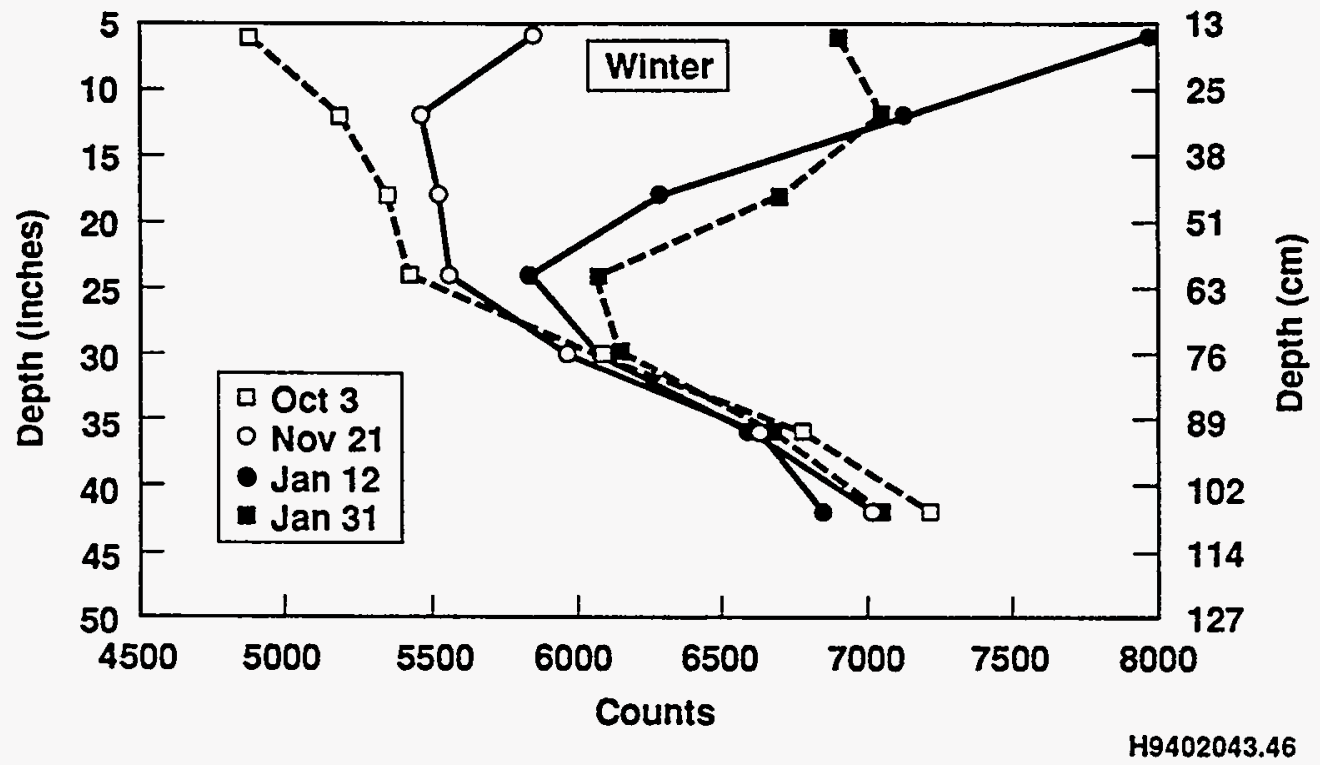

\subsection{Test 5 (Summer Treatment)}

Test 5 was conducted from April 1990 to August 1990 using Townsend ground squirrels and pocket mice (Table 1). Table 2 presents the soil moisture profile changes recorded during test 5 . Supplemental precipitation was added three times during the test period.

Test 5 followed the same trends as the previous summer treatments in that all the lysimeters lost water. The amount of water lost was similar among those lysimeters that received supplemental precipitation (Table 2). Figures 23 and 24 show the overall water loss for lysimeters containing Great Basin pocket mice, with supplemental precipitation added (1B) and without supplemental precipitation (2B). No effects caused by adding supplemental precipitation could be detected.

The hydroprobe readings from the two lysimeters that contained Great Basin pocket mice (1B, 2B) also show the same trend described above (Figures 25 and 26). These two graphs are similar in appearance; the data depicted in these figures do not indicate a noticeable difference between the lysimeter that received the supplemental precipitation the lysimeter that did not. 
Figure 23. Soil Moisture Profile Changes Measured in Test 5 (a lysimeter containing a pocket mouse and added supplemental precipitation).

Soil Moisture Profile Changes (Test 5)

Pocket Mouse (With Supplemental Precipitation)

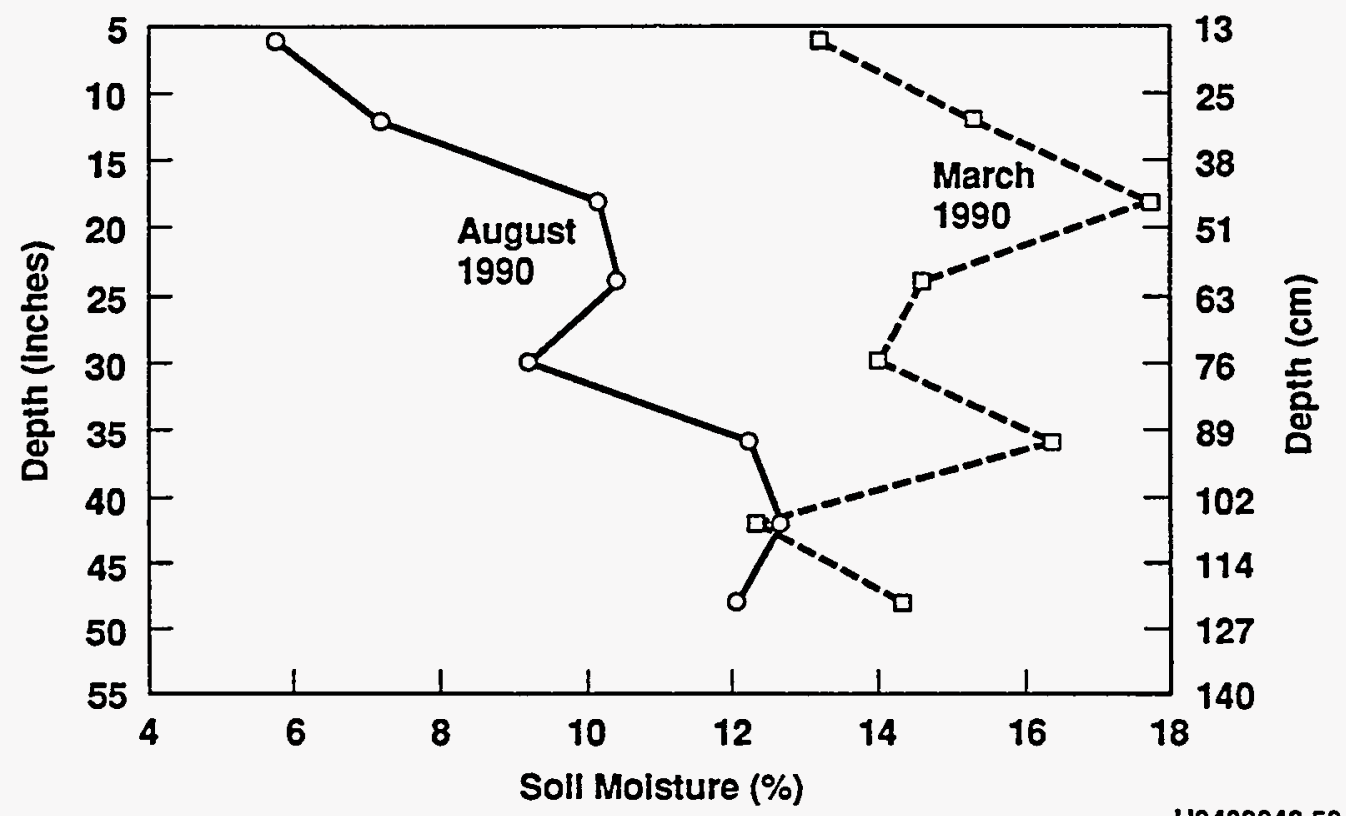

Figure 24. Soil Moisture Profile Changes Measured in Test 5

(a lysimeter containing a pocket mouse and no supplemental precipitation).

Soil Moisture Profile Changes (Test 5) Pocket Mouse (With No Supplemental Precipitation)

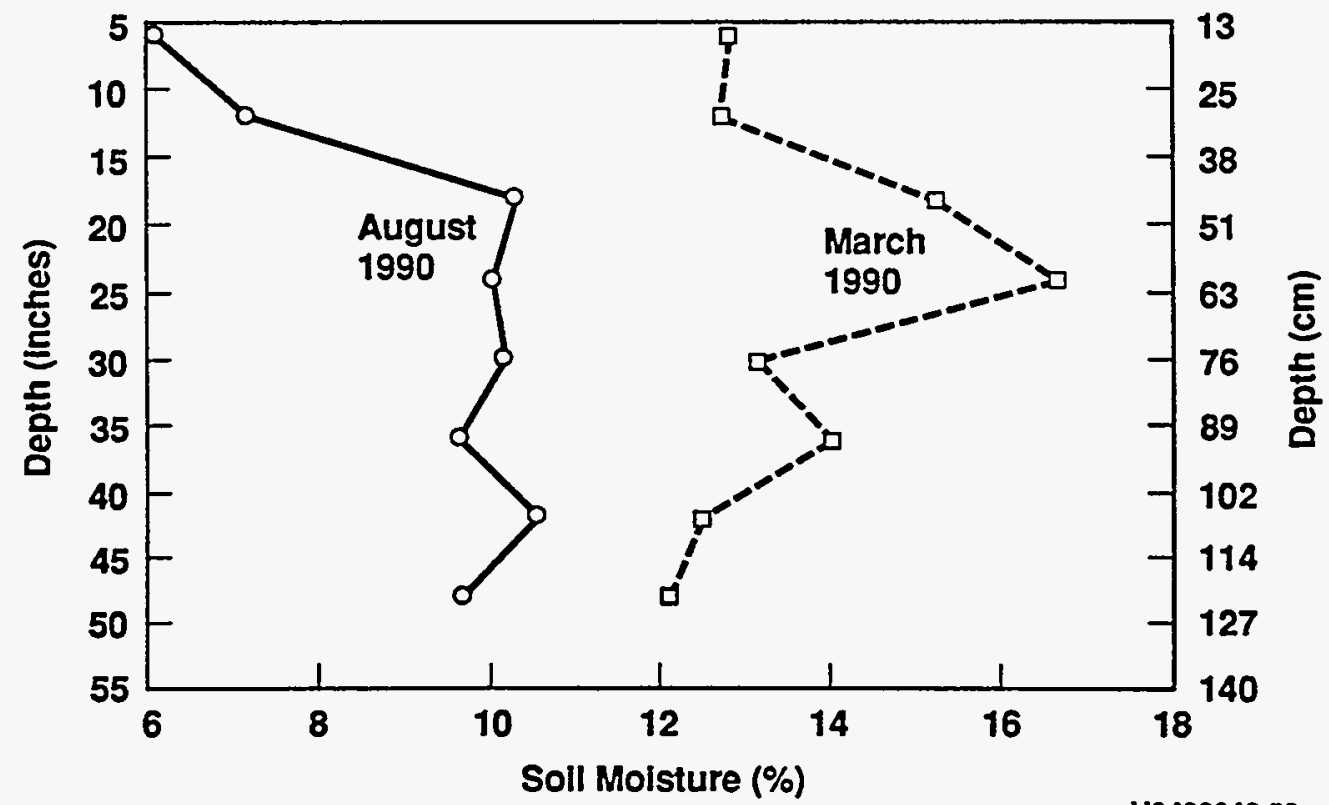

H9402043.53 
Figure 25. Hydroprobe Measurements Observed in Test 5

(a lysimeter containing a pocket mouse and added supplemental precipitation).

\section{Hydroprobe Readings (Test 5)}

Pocket Mouse (With Supplemental Precipitation)

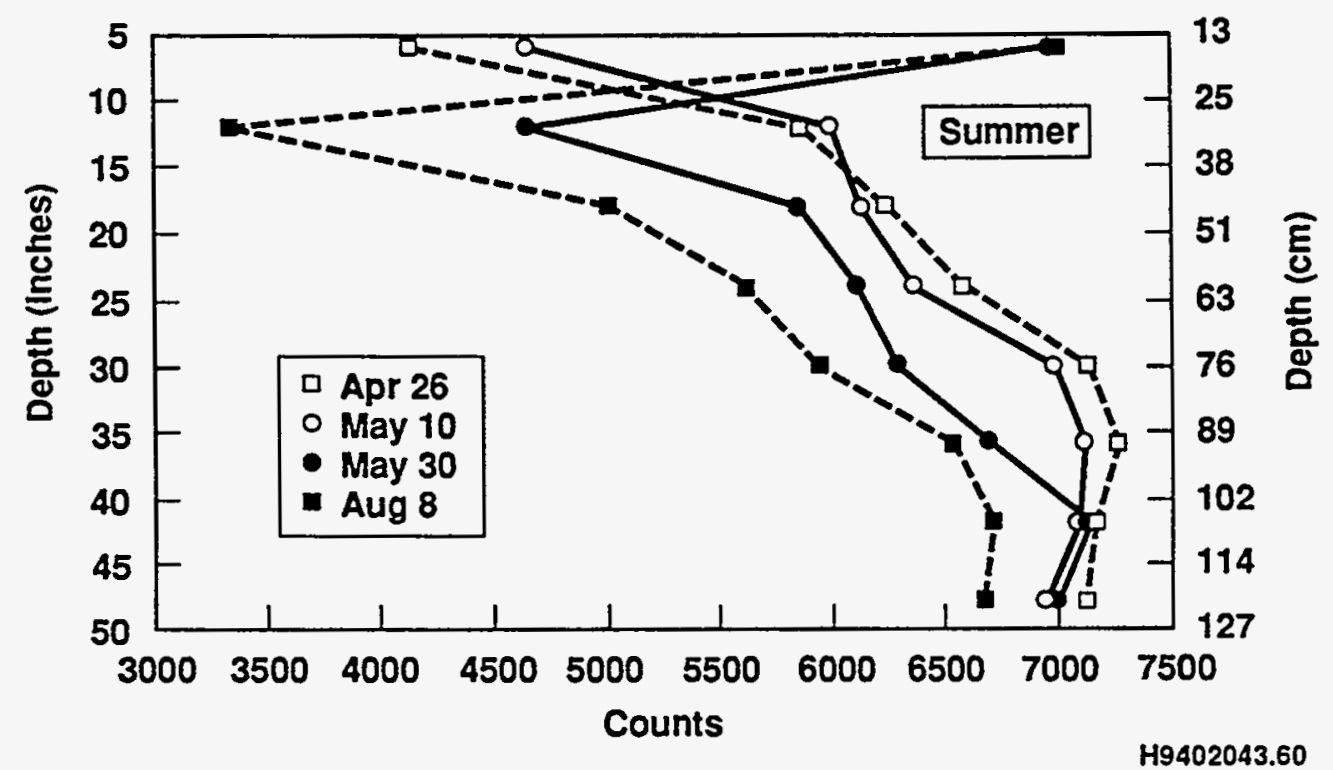

Figure 26. Hydroprobe Measurements Observed in Test 5

(a lysimeter containing a pocket mouse and no supplemental precipitation).

\section{Hydroprobe Readings (Test 5)}

Pocket Mouse (With No Supplemental Precipitation)

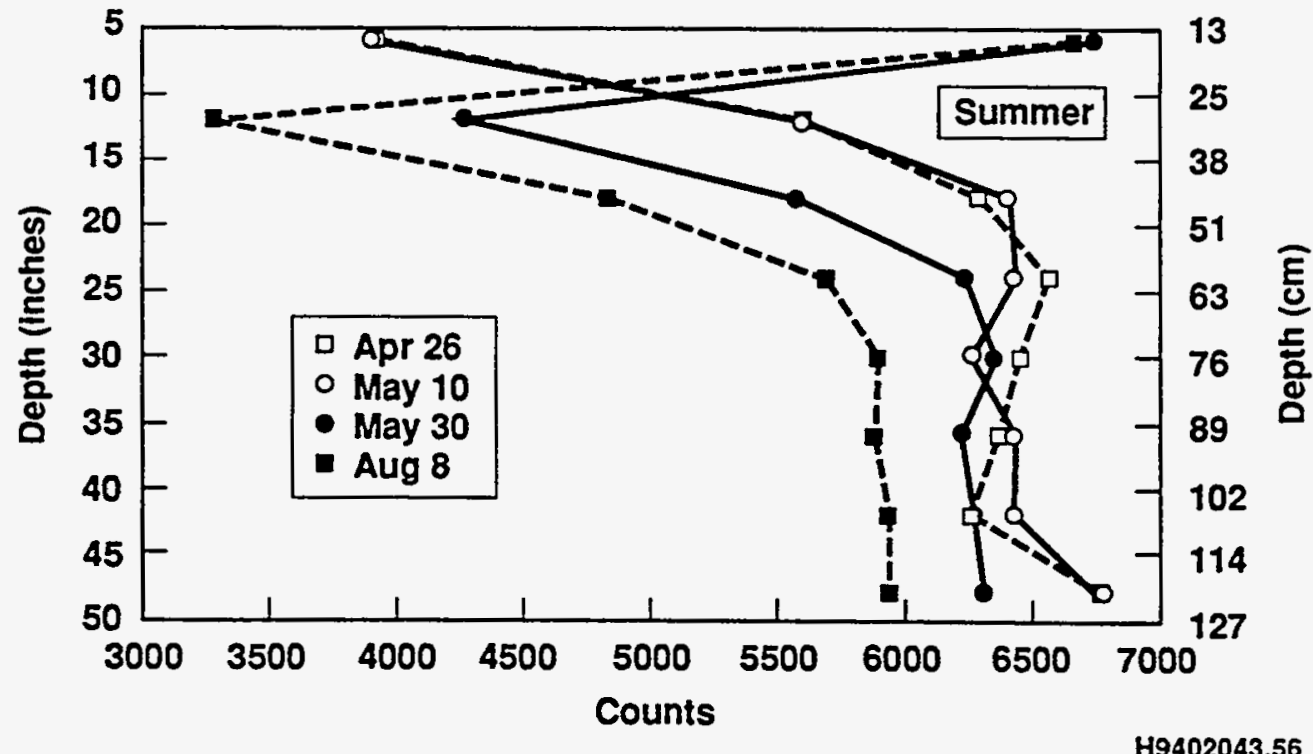




\subsection{Burrow Configurations}

Table 3 presents the results of the burrow excavations that were conducted for tests 1 through 4 . Burrows were unable to be excavated for test 5 because of soil sloughing and collapse, which occurred when the lysimeters were removed. Pocket gophers were the most prolific burrowers, followed by pocket mice and Townsend ground squirrels (Photo 10). The average depth of burrows was the same for pocket mice and pocket gophers (48 in.). Except to show the amount of burrowing in each lysimeter, this data cannot be extrapolated to pertain to natural conditions. The experimental design imposed on this study had a major effect on the amount of burrowing activity (Figure 12).

There are not enough data points to make meaningful comparisons of burrowing behavior among species or seasons. However, these burrow excavations did verify the plugging of burrow entrances and tunnels by pocket gophers and pocket mice, which is well documented. The constant burrowing and soil turnover exhibited by these small mammals did have the effect of altering the microtopography of the soil surface. Small depressions, holes, and mounds were created as a result of burrowing activities.

\subsection{Evaluation of Hanford Data}

The present study, which was conducted in an arid environment (the Hanford Site), did not indicate that small mammal burrows were allowing any significant water storage at depth and what water might be gained during the winter or high precipitation events would be removed during the spring and summer months, even when supplemental precipitation was added. This is especially significant because the experimental design imposed conditions on the lysimeters that should have contributed to increased water storage at depth. These conditions were caused by lack of vegetative cover, no water runoff, high animal and burrow densities, supplemental precipitation added at rates that do not occur normally, and burrows that extended to the bottom of the lysimeters.

\subsubsection{Transpiration}

During the study, vegetation was not allowed to become established. This eliminated any water loss from transpiration, which can be profound. Campbell and Gee (1990) and Gee et al. (1993) (lysimeter studies at the Hanford Site) showed that vegetation was the most important factor in preventing drainage. Vegetated treatments completely masked the three-times-average precipitation treatments on an annual basis by removing all available water from both the ambient and three-times-average treatments to a common water content and potential. The minimum water storage for vegetated treatments was about half that for nonvegetated treatments. Gee et al. (1993) concluded after $6 \mathrm{yr}$ of testing with no drainage occurring in vegetated treatments that surface isolation barrier designs with vegetated capillary barriers, will be successful in preventing recharge at the Hanford Site waste sites. 
Photo 10. Cross-Section of Pocket Gopher Burrow and Food Cache in One Lysimeter.

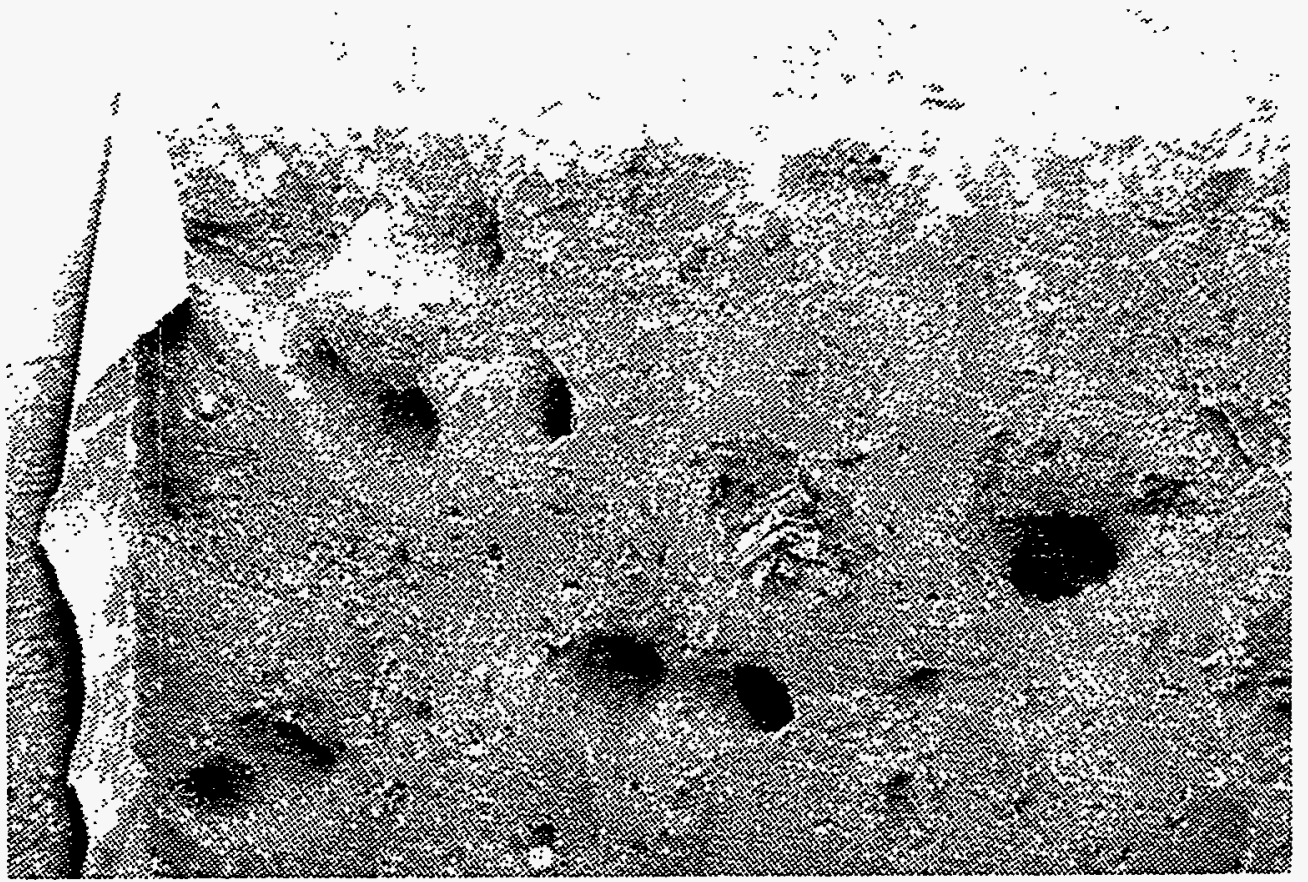

Photo 11. Holes and Depressions Created by the Townsend Ground Squirrel Fill Up Rapidly During High-Precipitation Events.

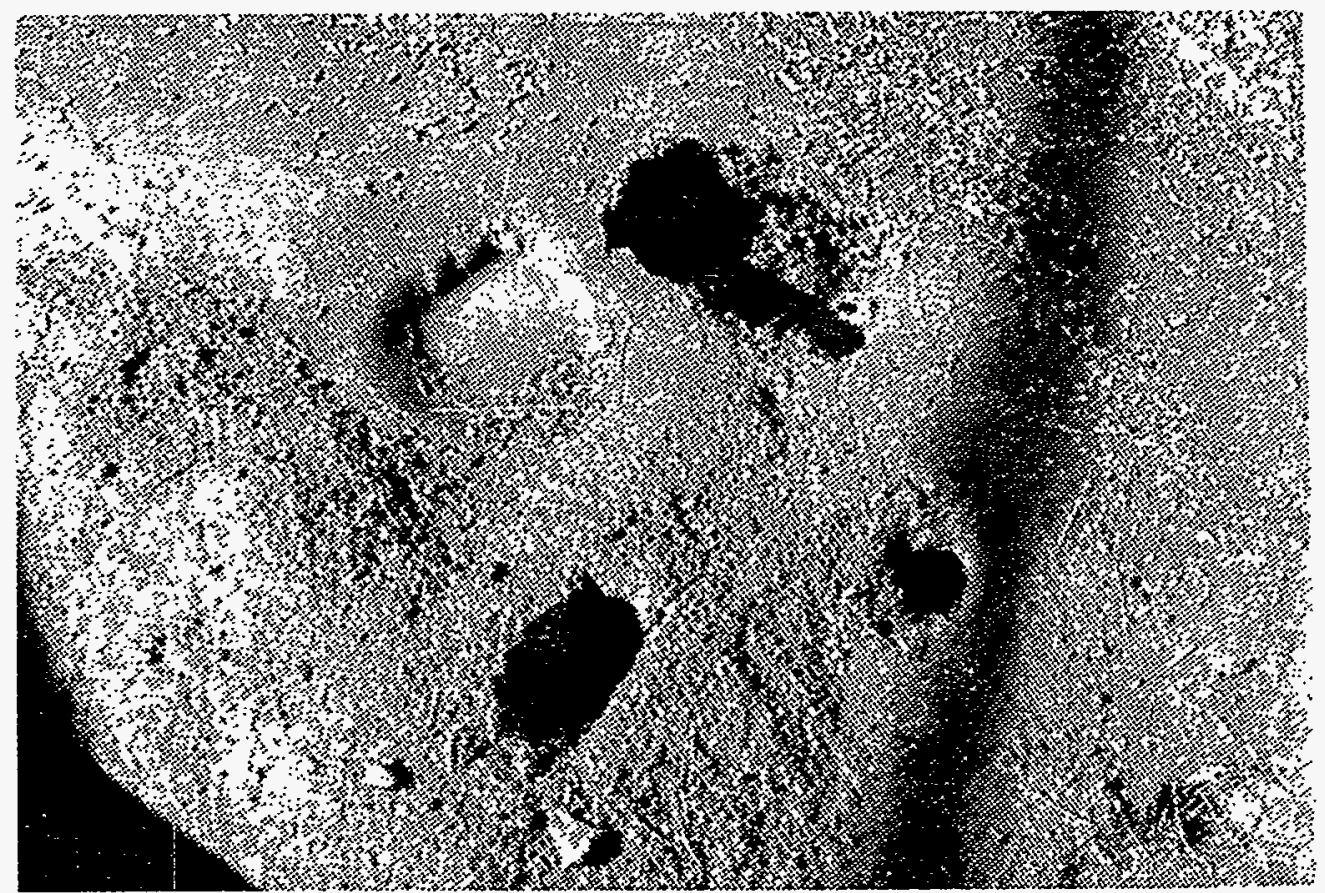


Table 3. Total Length (inches) and Maximum Depth of Burrow Systems for Tests 1-4.

\begin{tabular}{|c|c|c|c|c|}
\hline Test Number & $\begin{array}{l}\text { Lysimeter } \\
\text { number }\end{array}$ & Species & Total length & Maximum depth \\
\hline \multicolumn{5}{|c|}{ Summer treatment } \\
\hline $\begin{array}{l}\text { One } \\
\text { One } \\
\text { One } \\
\text { One }\end{array}$ & $\begin{array}{l}1 A^{a} \\
1 C^{a} \\
2 B \\
2 C\end{array}$ & $\begin{array}{l}\text { Pocket mouse } \\
\text { Townsend } \\
\text { Townsend } \\
\text { Pocket mouse }\end{array}$ & $\begin{array}{r}201 \\
54 \\
32 \\
321\end{array}$ & $\begin{array}{l}48 \\
24 \\
16 \\
40\end{array}$ \\
\hline \multicolumn{5}{|c|}{ Winter treatment } \\
\hline $\begin{array}{l}\text { Two } \\
\text { Two } \\
\text { Two } \\
\text { Two }\end{array}$ & $\begin{array}{l}1 \mathrm{~A} \\
1 \mathrm{C} \\
2 \mathrm{~A} \\
2 \mathrm{C}\end{array}$ & $\begin{array}{l}\text { Pocket gopher } \\
\text { Pocket mouse } \\
\text { Pocket gopher } \\
\text { Pocket gopher }\end{array}$ & $\begin{array}{l}384 \\
192 \\
444 \\
570\end{array}$ & $\begin{array}{l}44 \\
42 \\
52 \\
52\end{array}$ \\
\hline \multicolumn{5}{|c|}{ Summer treatment } \\
\hline $\begin{array}{l}\text { Three } \\
\text { Three } \\
\text { Three } \\
\text { Three }\end{array}$ & $\begin{array}{l}1 A^{a} \\
1 B^{a} \\
2 A \\
2 B\end{array}$ & $\begin{array}{l}\text { Townsend } \\
\text { Pocket gopher } \\
\text { Townsend } \\
\text { Pocket gopher }\end{array}$ & $\begin{array}{r}186 \\
213 \\
54 \\
420\end{array}$ & $\begin{array}{l}45 \\
57 \\
26 \\
54\end{array}$ \\
\hline \multicolumn{5}{|c|}{ Winter treatment } \\
\hline $\begin{array}{l}\text { Four } \\
\text { Four } \\
\text { Four } \\
\text { Four }\end{array}$ & $\begin{array}{l}1 A^{b} \\
1 B^{b} \\
2 A \\
2 B\end{array}$ & $\begin{array}{l}\text { Pocket gopher } \\
\text { Pocket mouse } \\
\text { Pocket gopher } \\
\text { Pocket mouse }\end{array}$ & $\begin{array}{l}318 \\
156 \\
102 \\
261\end{array}$ & $\begin{array}{l}58 \\
55 \\
12 \\
55\end{array}$ \\
\hline
\end{tabular}

${ }^{3} 1.65$ in. added water

b1.10 in. added water

The animal intrusion data reported here essentially show the same effects (water being removed) even without vegetation present. If vegetation had been allowed to grow in the animal-intrusion lysimeters, the overall water loss would have been greater and occurred at an even faster rate. Plant densities are usually greater in the vicinity of animal burrows.

\subsubsection{Water Runoff}

The design of the lysimeters ensured that no water runoff occurred during precipitation events, all water was contained. Even though the Hanford Site is considered to be a semi-arid environment, and water inputs are small, runoff can occur even though it is small and localized, occurring with infrequent heavy rains (Campbell and Harris, 1981).

During this study, the water infiltration rate was faster than the other two lysimeters, when supplemental precipitation was added to those lysimeters containing 
Townsend ground squirrels. The water had penetrated the soil matrix faster and deeper in the short term compared to lysimeters containing Great Basin pocket mice and pocket gophers. This was because there were usually several open holes and depressions that had been excavated by the ground squirrels, which facilitated the entry of water into the soil matrix (Photo 11). These burrow systems closely resemble channel system $A$, described previously by Dixon and Peterson (1971), which is characterized by numerous stable open channel ports exposed to free water and open to the atmosphere. Under this system, water is rapidly transferred to subsurface borders of the capillary system and readily exhausts displaced soil air.

\subsubsection{Burrow Density}

Burrow and animal densities were much higher than normal. Home range sizes were significantly less than would be found in a natural shrub steppe environment. By limiting animals to a small confined area and increasing the burrow densities, any burrow effects on water storage should have been observed.

\subsubsection{Supplemental Precipitation}

The supplemental precipitation, added by the rainulator in amounts equivalent to a $100-y r$ storm on a monthly basis, greatly exceeds any amount of water that could be expected to occur naturally, especially when these were applied two or three times during the test periods.

\subsubsection{Burrow Depths}

Because the animals usually burrowed to the bottom of the lysimeters, channels were created by which water could potentially reach the bottom of the lysimeter. Despite these conditions, the data did not indicate that animal burrows were contributing to water storage at depth.

\subsection{Water Loss in Burrows}

Water loss in our study probably resulted from a combination of at least three factors: (1) high ambient temperatures, which resulted in soil evaporation, (2) soil turnover and subsequent drying, and (3) burrow ventilation effects. All of the small mammals in this study were constantly turning the soil over (i.e., burrowing). Commonly, soil was excavated by the small mammals and brought to the surface during the night, and the soil was wetter than the surrounding surface soil. Usually within a few hours (or less) this excavated soil had dried out and looked like the surface soil.

Open and closed burrows allow air to enter, which has dries out the soil (King, 1984). This has been documented in many of the studies with moles, prairie dogs, and bank voles, which are discussed in previous sections. This same phenomenon

undoubtedly occurs with the species used in this study. 
The results from our study support the literature cited previously, especially concerning water infiltration and large pores connected to the surface. This study indicated that during high-precipitation events, open burrows made by Townsend ground squirrels and connected to the surface allowed water to penetrate deeper and faster than normal. However, this excess water was removed relatively quickly and actually made the burrow systems and surrounding soil drier than in nonburrow areas (Figure 27). This suggests that these burrow systems will actually enhance the long-term removal of water from the barrier, concerning especially those systems made by burrowing animals such as ground squirrels, which have open-burrow systems.

Burrow systems formed by Great Basin pocket mice and pocket gophers that are not connected to the surface reduce water infiltration because of burrow air pressures and mounding effects, which inhibit water penetration into a burrow by acting as a buffer or by diverting excess water away from the burrow system (Figure 27). These burrow systems also effectively slow down water infiltration by nature of the general burrow configuration (i.e., branching, mounding, and upturns).

\subsubsection{Soil Water Evaporation}

The data suggests that the high ambient temperature that results in soil water evaporation is probably the overriding factor contributing to the water losses observed in the present study. The two winter treatments were the only treatments that gained water during that time of the year when ambient temperatures were low. 

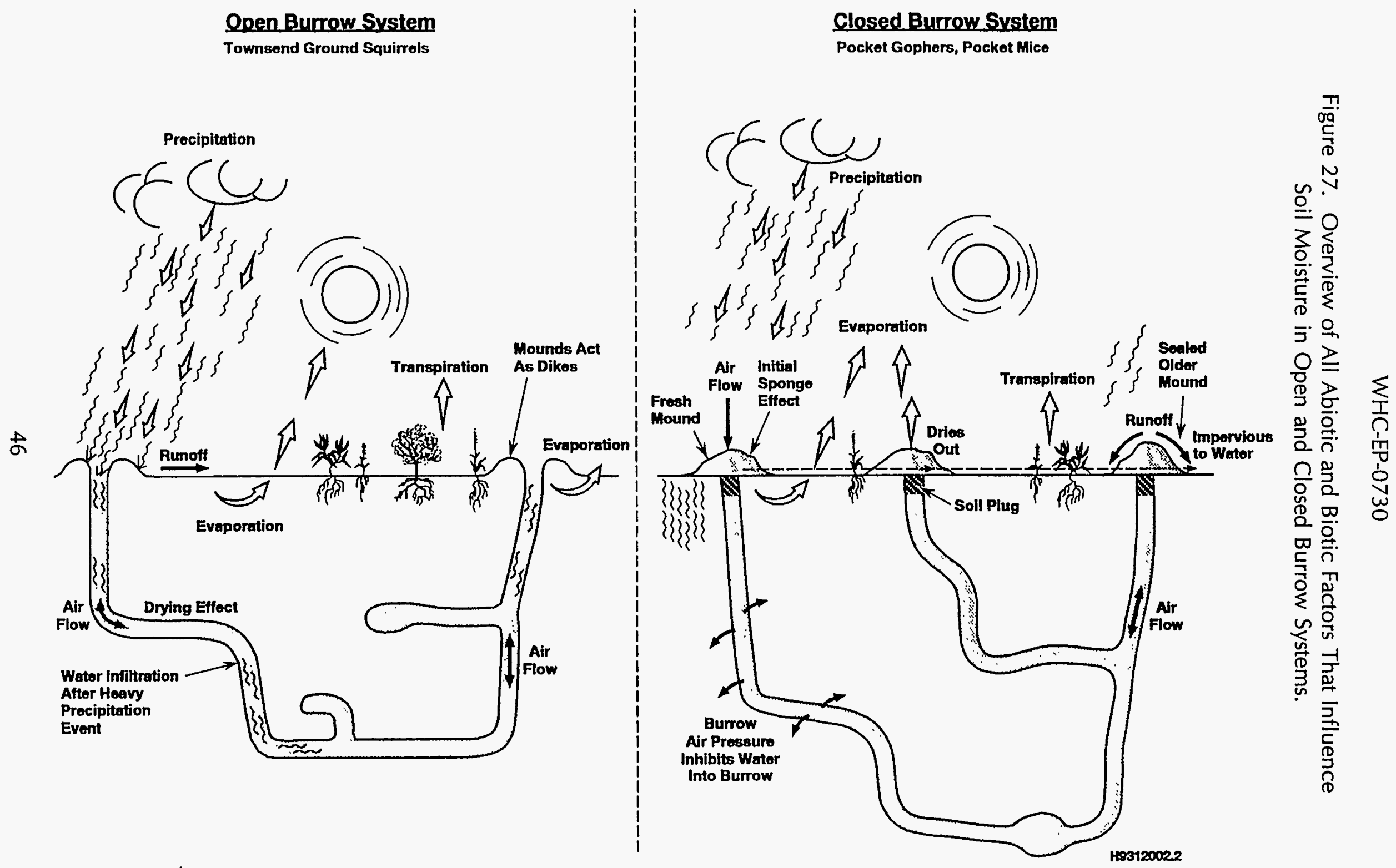


\subsection{SUMMARY}

Five animal intrusion tests were completed as part of this study. Information collected from these five tests indicated the following.

- During the summer months, a net water loss exited in all the lysimeters, including the controls and those lysimeters that received supplemental precipitation.

- During the winter months, all lysimeters gained water. This is probably a seasonal effect during a time when precipitation is greater and evaporation is low and may not be related to burrowing impacts on moisture.

- The data did not indicate that any long-term water storage had occurred as a direct result of animal burrowing activity. The soil moisture profile graphs generated from all five tests [lysimeters containing animals and lysimeters serving as controls (no animals)] were similar. This study did not indicate that animal burrows at the Hanford Site facilitate the retention of water at depth.

The lack of any significant water storage at depth and the overall water loss in the lysimeters occurred despite conditions that could be considered worst-case scenarios, which were imposed on the lysimeters. These conditions included no vegetative cover (no plant transpiration); no water runoff (all water contained); higher-than-normal animal and burrow densities; supplemental precipitation added at rates not expected to occur normally; and animals burrowed to the bottom of the lysimeters. The overall water loss appears to be caused primarily by soil evaporation, which is caused by high ambient temperatures in the spring and summer. Other causes of water loss are probably a combination of (1) constant soil turnover and subsequent drying, and (2) burrow ventilation effects.

This study did not address all potential climate changes, runoff events, and potential effects of other burrowing animals. However, increased water storage at the Hanford Site under the present climatic conditions appear to be negligible, considering that a protective barrier will allow for runoff, have a vegetative cover, experience normal animal densities and normal precipitation events. Studies conducted elsewhere in environments that receive more natural precipitation and have lower ambient temperatures may not observe results as pronounced as those observed at the Hanford Site. 


\subsection{REFERENCES}

Abaturov, B.C., 1972, "The Role of Burrowing Animals in the Transport of Mineral Substances in the Soil," Pedobiologia 12:261-266.

Arkley, R.J. and H.C. Brown, 1954, The Origin of Mima Mound (Hogwallow) Microrelief in the Far Western States, Soil Sci. Soc. Proc.

Arthur, W.J., O.D. Markham, C.R Groves, B.L. Keller, and D.K. Halford, 1986, "Radiation Dose to Small Mammals Inhabiting a Solid Radioactive Waste Disposal Area," J. Applied Ecol, 23:13-26.

Barnes, P.W. and A.T. Harrison, 1982, "Species Distribution and Community Organization in a Nebraska Sandhills Mixed Prairie as Influenced by Plant/Soil-Water Relationships," Oecologia 52:192-201.

Borst, G., 1968, "The Occurrence of Crotovinas in Some Southern California Soils. Trans. 9th Int. Congress Soil Sci.," Adelaide 2:19-22.

Burt, W.H. and R.P. Grossenheider, 1980, A Field Cuide to the Mammals North America north of Mexico, Third Edition, Houghton Mifflin Company, Boston, Massachusetts.

Cadwell, L.L., L.E. Eberhardt, and M.A. Simmons, 1989, Animal Intrusion Studies for Protective Barriers: Status Report for FY 1988, PNL-6869, Pacific Northwest Laboratory, Richland, Washington.

Cadwell, L.L., 1991, Hanford Site Protective Barrier Development Program: Fiscal Year 1990 Highlights, PNL-7831, Pacific Northwest Laboratory, Richland, Washington.

Cameron, G.N., S.R. Spencer, B.D. Eshelman, L.R. Williams and M.J. Gregory, 1988, "Activity and Burrow Structure of Attwater's Pocket Gopher (Ceomys attwateri)," Jour. of Mammalogy 69:667-669.

Campbell, G.S. and G.A. Harris, 1977, "Water Relations and Water Use Patterns for Artemisia tridentata Nutt. in Wet and Dry Years," Ecology 58:652-659.

Campbell, G.S. and G.A. Harris, 1981, "Modeling soil-water-plant-atmosphere systems of desert," in D.D. Evans and J.L. Thames, eds., Water in Desert Ecosystems, Dowden, Hutchinson and Ross, Stroudsburg, Pennsylvania.

Campbell, M.D. and G.W. Gee, 1990, Field Lysimeter Test Facility: Protective Barrier Test Results (FY 1990, the Third Year), PNL-7558, Pacific Northwest Laboratory, Richland, Washington. 
Campbell, M.D., G.W. Gee, M.J. Kanyid, and M.L. Rockhold, 1990, Field Lysimeter Test Facility: Second Year (FY 1989) Test Results, PNL-7209, Pacific Northwest Laboratory, Richland, Washington.

Carlson, D.C. and E.M. White, 1987, "Effects of Prairie Dogs on Mound Soils," Soil Sci. Soc. Am. J. 51:389-393.

Chichester, F.W. and S.J. Smith, 1978, "Disposition of N-labeled Fertilizer Nitrate Applied During Corn Culture in Field Lysimeters," I. Environ. Quality 7:227-232.

Cox, G.W. and J. Hunt, 1990, "Form of Mima Mounds in Relation to Occupancy by Pocket Gophers," Journ. of Mamm. 71:1:91-94.

Day, A.M., 1931, "Soil Erosion is often caused by burrowing rodents," U.S. Dept. Agr., Yearbook 1931:481-484.

Dixon, R.M. and A.E. Peterson, 1971, "Water Infiltration Control: A Channel System Concept," Soil Science Soc. Amer. Proc. 35:968-973.

Duley, F.L, 1939, Soil Science Soc. Am. Proc. 4:60-64.

Ehlers, W., 1975, "Observations on Earthworm Channels and Infiltration on Tilled and Untilled Loess Soil," Soil Science 119:3:242-249.

Ellison, L., 1946, "The Pocket Gopher in Relation to Soil Erosion on Mountain Range," Ecology 27:101-112.

Ellison, L. and C.M. Aldous, 1952, "Influence of Pocket Gophers on Vegetation of Subalpine Grassland in Central Utah," Ecology 33:2:177-186.

Fitzner, R.E. and R.H. Gray, 1991, "The Status, Distribution and Ecology of Wildlife on the U.S. DOE Hanford Site: A Historical Overview of Research Activities," Envir. Monitoring and Assessment 18:173-202.

Gano, K.A., 1979, Analysis of Small Mammal Populations Inhabiting the Environs of a Low-Level Radioactive Waste Pond, PNL-2479, Pacific Northwest Laboratory Richland, Washington.

Gardner, W.H., 1986, "Water Content," Methods of Soil Analysis 493-544, American Soc. of Agronomy, Inc, Madison, Wisconsin.

Garten, C.T., Jr., 1980, "Field Determination of Cs-137 Assimilation Efficiencies in Wild Cotton Rats (Sigmodon hispidus)," Health Physics 38:80-83. 
Gee, G.W., D.G. Felmy, J.C. Ritter, M.D. Campbell, J.L. Downs, M.J. Fayer, R.R. Kirkham, S.O. Link, 1993, Field Lysimeter Test Facility Status Report IV: FY 1993, PNL-8911, Pacific Northwest Laboratory, Richland, Washington.

Grant, W.E., N.R. French, and L.J. Folse, Jr., 1980, "Effects of Pocket Gopher Mounds on Plant Production in Shortgrass Prairie Ecosystems," The Southwestern Naturalist (25) 2:215-224.

Grinnell, J., 1933, "Native California Rodents in Relation to Water Supply," Jour. Mammalogy 14:293-298.

Hakonson, T.E., J.L. Martinez, and G.C. White, 1982, "Disturbance of a Low-level Waste Burial Site Cover by Pocket Gophers," Health Physics 42:6:871-873.

Hanks, R.J., H.R. Gardner, and M.L. Fairbourn, 1967, "Evaporation of Water from Soils as Influenced by Drying With Wind or Radiation," Soil Sci America Proc. 31:5.

Hopp, H. and C.S. Slater, 1948, Soil Sci. 66:421-428.

Horton, R.E., 1940, "An Approach Toward a Physical Interpretation of Infiltration Capacity," Soil Sci. Soc. Amer. Proc. 5:399-417.

Johnson, D.L., D.W. Stegner, D.N. Johnson, and R.J. Schaetzl, 1987, "Proisotropic and Proanisotropic Processes of Pedoturbation," Soil Science 143:4.

King, J.A., 1984, "Historical Ventilations on a Prairie Dog Town," The Biology of Ground-Dwelling Squirrels 20:447-456, Univ. of Nebraska Press, Lincoln, Nebraska.

Kleingartner, L.G., 1977, "Data on Weather From 1924-1976 Irrigated Agriculture Research and Extension Center Near Prosser, Washington," Bulletin 858, College of Agriculture Research Center, Washington State University.

Krebs, J.R. and N.B. Davies, 1981, An Introduction to Behavioral Ecology, p. 494, Sinauer Associates, Sunderland, Massachusetts.

Landeen, D.S. and R.M. Mitchell, 1981, Intrusion of Radioactive Waste Burial Sites by the Great Basin Pocket Mouse (Perognathus parvus), RHO-SA-211, Rockwell Hanford Operations, Richland, Washington.

Landeen, D.S. and R.M. Mitchell, 1982, The Role of Burrowing Activities of the Great Basin Pocket Mouse (Perognathus parvus) in the Dispersal of Radionuclides on a Decommissioned Pond, RHO-HS-SA-1OP, Rockwell Hanford Operations, Richland, Washington. 
Landeen, D.S., L.L. Cadwell, L.E. Eberhardt, R.E. Fitzner, M.A. Simmons, 1990, Animal Intrusion Field Test Plan, WHC-EP-0253, Westinghouse Hanford Company, Richland, Washington.

Last, G.V., M.A. Glennon, M.A. Young, and G.W. Gee, 1987, Protective Barrier Materials Analysis: Fine Soil Site Characterization, PNL-6314, Pacific Northwest Laboratory, Richland, Washington.

Link, S.O., W.J. Waugh, J.L. Downs, M.E. Thiede, J.C. Chatters, and G.W. Gee, 1994, "Effects of Coppice Dune Topography and Vegetation on Soil Water Dynamics in a Cold-Desert Ecosystem," Journal of Arid Environments (in press).

Manville, R.H., 1959, "The Columbian Ground Squirrel in Northwestern Montana," Journal of Mammalogy, 40:1:26-45.

McDonough, W.T., 1974, "Revegetation of Gopher Mounds on Aspen Range in Utah," Great Basin Naturalist, 34:4:267-275.

Olszewski, J.L. and S. Skoczen, 1965, "The Airing of Burrows of the Mole, Talpa europae Linnaeus, 1758," Acta Theriologica, 11:181-193.

Popova, N.N., 1962, "The Effect of the Digging Activity of Small Size Mammals on the Distribution of Soil Moisture in Areas Covered with Coniferous and Broad Leaved Woods," Biull. Mosk. Obsc. Ispit. Prir., Otd. Biol., 67:5:29-35 (in Russian with English Summary).

Reynolds, T.D. and J.W. Laundre, 1988, "Vertical Distribution of Soil Removed by Four Species of Burrowing Rodents in Disturbed and Undisturbed Soils," Health Physics, 54:4:445-450.

Rogers, L.E. and R.J. Lavigne, 1974, "Environmental Effects of Western Harvester Ants on the Shortgrass Plains Ecosystem," Environ. Entomol. 3:994-997.

Ross, B.A., J.R. Tester, and W.J. Breckenridge, 1968, "Ecology of Mima-Type Mounds in Northwestern Minnesota," Ecology 49:1.

Scheffer, T.H., 1938, "Pocket Mice of Washington and Oregon in Relation to Agriculture," USDA Bulletin No. 608, Washington, D.C.

Schmidt-Nielsen, B. and K. Schmidt-Nielsen, 1950, "Evaporative Water Loss in Desert Rodents in Their Natural Habitat," Ecology 31:75-85.

Skoczen, S., H. Nagawiecka, K. Boron, and A. Galka, 1976, "The Influence of Mole Tunnels on Soil Moisture in Pastures," Acta Theriologica 21:543-548. 
Shaw, W.T., 1925, "Duration of the Aestivation and Hibernation of the Columbia Ground Squirrel," Ecology 6:75-81.

Sheets, R.G., R.L. Linder, and R.B. Dahlgren, 1971, "Burrow Systems of Prairie Dogs in South Dakota," J. Mamm. 52:451-453.

Stone, W.A., J.M. Thorp, O.P. Gifford, and D.J. Hoitink, 1983, Climatological Summary for the Hanford Area, PNL-4622, Pacific Northwest Laboratory, Richland, Washington.

Swanson, N.P., 1965, "Rotating-boom Rainfall Simulator," Trans ASAE, 8(1):71-72.

Taylor, W.P., 1935, "Some Animal Relations to Soils," Ecology 16:127-136.

Thorne, D.H. and D.C. Andersen, 1990, "Long-term Soil-Disturbance Pattern by a Pocket Gopher, Geomys bursarius," Jour. of Mammalogy 71:1:84-89.

Turner, G.T., R.M. Hansen, V.H. Reid, H.P. Tietjen, and A.L. Ward, 1973, "Pocket Gophers and Colorado Mountain Rangeland," Colorado State University Exp. Station Bulletin 544S.

Ursic, S.J. and R.J. Esher, 1988, "Influence of Small Mammals on Stormflow Responses of Pine-Covered Catchments," Water Resources Bulletin 24(1), American Water Resources Association.

Vogel, S., C.P. Ellington, and D.L. Kilgore, 1973, "Wind-induced Ventilation of the Burrows of the Prairie Dog, Cynomys ludovicianus," J. Comp. Physiol. 85:1-14.

Wilson, L.G. and J.N. Luthin, 1963, "Effect of Air Flow Ahead of Wetting Front on Infiltration," Soil Sci. 96:136-143.

Wildung, R.E. and T.R. Garland, 1988, Soils: Carbon and mineral cycling processes in Shrub-steppe Balance and Change in a Semi-Arid Terrestrial Ecosystem, (W.H. Rickard, L.E. Rogers, B.E. Vaughan, and S.R. Liebetrau, Eds.), 23-59, Elsevier, Amsterdam.

Wing, N.R., 1993, Permanent Isolation Surface Barrier Development Plan, WHC-EP-0673, Westinghouse Hanford Company, Richland, Washington.

Winsor, T.F. and F.W. Whicker, 1980, "Pocket Gophers and Redistribution of Plutonium in the Soil," Health Physics 39:257-262. 
WHC-EP-0730

\section{DISTRIBUTION}

Number of copies

OFFSITE

3

U.S. Environmental Protection

Agency

Richland, Washington 99352

D. R. Einan

B5-01

P. S. Innis

B5-01

D. R. Sherwood

3

Washington Department of Ecology

Mail Stop PV-11,

Olympia, Washington 98504-8711

C. Cline

S. F. Cross

L. Goldstein

1

Washington Department of Wildlife Lower River Road

Benton City, Washington 99320

L. Fitzner

1

Washington Department of Wildlife 2802 Fruitvale Blvd.

Yakima, Washington 98902

3 Golder Associates, Inc.

4104 148th Ave. NE

Redmond, Washington 98052

Library

L. Swenson

W. Wright 
WHC-EP-0730

\section{DISTRIBUTION (cont.)}

Number of copies

$5 \quad$ Washington Natural Heritage Program

Department of Natural Resources

P.O. Box 47047

Olympia, Washington 98504-7047

J. Gammon

R. Shuler

M. Sheehan (3)

$2 \quad$ The Nature Conservancy

Washington Field Office

217 Pine St. Suite 1100

Seattle, Washington 98101

Curt Soper

ONSITE

$83 \quad$ U.S. Department of Energy

Richland Operations Office

J. Erickson

A5-19

J. D. Goodenough

A5-19

E. D. Goller

A5-19

J. M. Hennig

A5-21

Public Reading Room (2)

A $1-65$

L. L. Cadwell *

K6-63

M. D. Campbell

K6-77

S. A. Carver

P8-55

C. E. Cushing

K6-54

M. J. Fayer *

G. W. Gee *

K6-77

M. W. Ligotke

K6-77

S. Link

P7-59

D. E. Robertson

K6-63

K. L. Petersen *

P8-01

M. R. Sackschewsky *

K6-60

Technical Files

K6-63

$\mathrm{K} 1-11$ 


\section{DISTRIBUTION (cont.)}

Number of copies

ONSITE

M. R. Adams

H6-01

D. L. Crockford

$\mathrm{H} 4-14$

D. H. Deford

H6-07

D. A. Duranceau

$\mathrm{H} 4-14$

K. R. Fecht

H6-06

T. W. Ferns

A5-19

R. D. Fox

H6-07

K. A. Gano

$\mathrm{X} 0-21$

C. J. Geier

R2-54

E. W. Gerber

R3-36

C. E. Heiden

H6-01

R. P. Henckel

H6-02

S. J. Hope

H4-79

A. R. Johnson

H6-30

C. J. Kemp

H4-14

D. S. Landeen (35)

H4-14

T. D. Lefrancois

H4-79

J. G. Lucas

H6-01

R. M. Mitchell

H6-01

D. R. Myers

R. Ovink

T4-01

F. V. Roeck

H4-79

H6-01

R. C. Roos

H6-01

F. A. Ruck III

H6-23

J. W. Schmidt

H6-30

J. C. Sonnichsen

$\mathrm{H} 4-14$

J. A. Stegan

H6-03

S. G. Weiss

$\mathrm{H} 6-02$

W. P. Whiting

B3-25

N. R. Wing *

H4-14

Central Files *

L8-04

I R A * (3)

L8-07

* Receives appendix 
APPENDIX A

SOIL MOISTURE PROFILE CHANGES CALCULATED FROM THE GRAVIMETRIC SOIL SAMPLING AT THE BEGINNING AND END OF EACH TEST 
Table A-1. Soil Moisture Profile Changes During First Test Conducted April 88 to October 88 . (sheet 1 of 2)

\begin{tabular}{|c|c|c|c|c|}
\hline Box number & Depth (in.) & $\begin{array}{c}\text { Initial } \\
\text { moisture }(\%)\end{array}$ & $\begin{array}{c}\text { Ending } \\
\text { moisture }(\%)\end{array}$ & $\begin{array}{l}\text { Percent } \\
\text { change }\end{array}$ \\
\hline \multicolumn{5}{|c|}{ Species: Pocket Mouse } \\
\hline $1 \mathrm{~A}$ & 6 & 19.82 & 6.89 & -12.93 \\
\hline $1 \mathrm{~A}$ & 12 & 18.66 & 8.67 & -9.99 \\
\hline $1 \mathrm{~A}$ & 18 & 18.82 & 9.31 & -9.51 \\
\hline $1 \mathrm{~A}$ & 24 & 21.38 & 9.46 & -11.92 \\
\hline $1 \mathrm{~A}$ & 30 & 19.31 & 10.90 & -8.41 \\
\hline $1 \mathrm{~A}$ & 36 & 20.14 & 10.92 & -9.22 \\
\hline $1 \mathrm{~A}$ & 42 & 20.42 & 10.74 & -9.68 \\
\hline $1 \mathrm{~A}$ & 48 & 19.99 & 10.23 & -9.76 \\
\hline $1 \mathrm{~A}$ & 54 & 20.01 & & -20.01 \\
\hline Average & & 19.84 & 9.64 & -11.27 \\
\hline \multicolumn{5}{|c|}{ Species: Control } \\
\hline $1 \mathrm{~B}$ & 6 & 16.48 & 7.87 & -8.61 \\
\hline 1B & 12 & 14.74 & 9.45 & -5.29 \\
\hline $1 \mathrm{~B}$ & 18 & 17.74 & 11.10 & -6.64 \\
\hline $1 \mathrm{~B}$ & 24 & 18.25 & 11.78 & -6.47 \\
\hline 1B & 30 & 20.94 & 12.38 & -8.56 \\
\hline $1 \mathrm{~B}$ & 36 & 17.28 & 12.46 & -4.82 \\
\hline $1 \mathrm{~B}$ & 42 & 16.11 & 11.42 & -4.69 \\
\hline $1 \mathrm{~B}$ & 48 & 17.34 & & \\
\hline Average & & 17.36 & 10.92 & -6.44 \\
\hline \multicolumn{5}{|c|}{ Species: Townsend } \\
\hline $1 \mathrm{C}$ & 6 & 14.76 & 8.57 & -6.19 \\
\hline $1 C$ & 12 & 14.66 & 9.90 & -4.76 \\
\hline $1 \mathrm{C}$ & 18 & 16.02 & 10.42 & -5.60 \\
\hline $1 C$ & 24 & 17.51 & 11.45 & -6.06 \\
\hline $1 \mathrm{C}$ & 30 & 18.86 & 12.22 & -6.64 \\
\hline $1 \mathrm{C}$ & 36 & 18.90 & 12.28 & -6.62 \\
\hline $1 C$ & 42 & 19.99 & 11.68 & -8.31 \\
\hline $1 \mathrm{C}$ & 48 & 18.18 & 10.81 & -7.37 \\
\hline Average & & 17.36 & 10.92 & -6.44 \\
\hline
\end{tabular}


Table A-1. Soil Moisture Profile Changes During First Test Conducted April 88 to October 88 . (sheet 2 of 2)

\begin{tabular}{|c|c|c|c|c|}
\hline Box number & Depth (in.) & $\begin{array}{c}\text { Initial } \\
\text { moisture (\%) }\end{array}$ & $\begin{array}{c}\text { Ending } \\
\text { moisture }(\%)\end{array}$ & $\begin{array}{l}\text { Percent } \\
\text { change }\end{array}$ \\
\hline \multicolumn{5}{|c|}{ Species: Control } \\
\hline $2 A$ & 6 & 18.70 & 5.68 & -13.02 \\
\hline $2 A$ & 12 & 15.97 & 8.30 & -7.67 \\
\hline $2 \mathrm{~A}$ & 18 & 18.58 & 9.44 & -9.14 \\
\hline $2 \mathrm{~A}$ & 24 & 16.16 & 9.93 & -6.23 \\
\hline $2 \mathrm{~A}$ & 30 & 16.95 & 10.68 & -6.27 \\
\hline $2 \mathrm{~A}$ & 36 & 12.95 & 10.30 & -2.65 \\
\hline $2 \mathrm{~A}$ & 42 & 13.92 & 9.59 & -4.33 \\
\hline Average & & 16.18 & 8.09 & -7.04 \\
\hline \multicolumn{5}{|c|}{ Species: Townsend } \\
\hline $2 \mathrm{~B}$ & 6 & 17.34 & 6.12 & -11.22 \\
\hline $2 \mathrm{~B}$ & 12 & 17.34 & 8.15 & -9.19 \\
\hline $2 B$ & 18 & 17.03 & 9.75 & -7.28 \\
\hline $2 \mathrm{~B}$ & 24 & 14.90 & 10.39 & -4.51 \\
\hline $2 \mathrm{~B}$ & 30 & 15.41 & 10.30 & -5.11 \\
\hline $2 \mathrm{~B}$ & 36 & 13.34 & 9.15 & -4.19 \\
\hline $2 \mathrm{~B}$ & 42 & 14.16 & 9.88 & -4.28 \\
\hline Average & & 15.65 & 8.31 & -6.54 \\
\hline \multicolumn{5}{|c|}{ Species: Pocket Mouse } \\
\hline $2 \mathrm{C}$ & 6 & 13.01 & 8.49 & -4.52 \\
\hline $2 C$ & 12 & 11.85 & 4.87 & -6.98 \\
\hline $2 \mathrm{C}$ & 18 & 14.56 & 9.18 & -5.38 \\
\hline $2 \mathrm{C}$ & 24 & 13.63 & 10.12 & -3.51 \\
\hline $2 C$ & 30 & 13.86 & 10.61 & -3.25 \\
\hline $2 C$ & 36 & 13.71 & 10.84 & -2.87 \\
\hline $2 C$ & 42 & 14.94 & 10.66 & -4.28 \\
\hline Average & & 13.65 & 8.46 & -4.40 \\
\hline
\end{tabular}


Table A-2. Soil Moisture Profile Changes During Second Test. (sheet 1 of 2)

\begin{tabular}{|c|c|c|c|c|}
\hline Box number & Depth (in.) & $\begin{array}{c}\text { Initial } \\
\text { moisture }(\%)\end{array}$ & $\begin{array}{c}\text { Ending } \\
\text { moisture (\%) }\end{array}$ & $\begin{array}{l}\text { Percent } \\
\text { change }\end{array}$ \\
\hline \multicolumn{5}{|c|}{ Species: Pocket Gopher } \\
\hline $1 \mathrm{~A}$ & 6 & 10.69 & & \\
\hline $1 \mathrm{~A}$ & 12 & 11.03 & 12.37 & 1.34 \\
\hline $1 \mathrm{~A}$ & 18 & 10.05 & 12.78 & 2.73 \\
\hline $1 \mathrm{~A}$ & 24 & 9.53 & 11.55 & 2.02 \\
\hline $1 \mathrm{~A}$ & 30 & 8.72 & 13.53 & 4.81 \\
\hline $1 \mathrm{~A}$ & 36 & 9.63 & 11.99 & 2.36 \\
\hline $1 \mathrm{~A}$ & $\dot{4} 2$ & 10.11 & 9.88 & -0.23 \\
\hline $1 \mathrm{~A}$ & 48 & 9.28 & 9.64 & 0.36 \\
\hline Average & & 9.88 & 11.68 & 1.91 \\
\hline \multicolumn{5}{|c|}{ Species: Control } \\
\hline $1 \mathrm{~B}$ & 6 & 9.39 & 9.73 & 0.34 \\
\hline 1B & 12 & 9.64 & 11.23 & 1.59 \\
\hline 1B & 18 & 9.94 & 13.06 & 3.13 \\
\hline $1 \mathrm{~B}$ & 24 & 9.72 & 12.04 & 2.33 \\
\hline $1 \mathrm{~B}$ & 30 & 8.66 & 11.91 & 3.24 \\
\hline 1B & 36 & 9.49 & 9.06 & -0.44 \\
\hline 1B & 42 & 9.45 & & \\
\hline 1B & 48 & 9.80 & & \\
\hline Average & & 9.51 & 11.17 & 1.70 \\
\hline \multicolumn{5}{|c|}{ Species: Pocket Mouse } \\
\hline $1 \mathrm{C}$ & 6 & 8.40 & 10.73 & 2.33 \\
\hline $1 \mathrm{C}$ & 12 & 9.34 & 12.24 & 2.90 \\
\hline $1 \mathrm{C}$ & 18 & 9.28 & 15.08 & 5.81 \\
\hline $1 \mathrm{C}$ & 24 & 9.60 & 13.90 & 4.31 \\
\hline $1 \mathrm{C}$ & 30 & 10.15 & 13.47 & 3.32 \\
\hline $1 \mathrm{C}$ & 36 & 10.90 & 11.74 & 0.84 \\
\hline $1 \mathrm{C}$ & 42 & 9.60 & 11.53 & 1.93 \\
\hline $1 \mathrm{C}$ & 48 & 10.22 & 10.54 & 0.32 \\
\hline Average & & 9.68 & 12.40 & 2.72 \\
\hline
\end{tabular}


Table A-2. Soil Moisture Profile Changes During Second Test. (sheet 2 of 2)

\begin{tabular}{|c|c|c|c|c|}
\hline Box number & Depth (in.) & $\begin{array}{c}\text { Initial } \\
\text { moisture (\%) }\end{array}$ & $\begin{array}{c}\text { Ending } \\
\text { moisture }(\%)\end{array}$ & $\begin{array}{l}\text { Percent } \\
\text { change }\end{array}$ \\
\hline \multicolumn{5}{|c|}{ Species: Pocket Gopher } \\
\hline $2 A$ & 6 & 8.22 & 10.47 & 2.25 \\
\hline $2 \mathrm{~A}$ & 12 & 7.71 & 11.57 & 3.85 \\
\hline $2 A$ & 18 & 6.34 & 13.86 & 7.52 \\
\hline $2 \mathrm{~A}$ & 24 & 9.49 & 16.06 & 6.57 \\
\hline $2 \mathrm{~A}$ & 30 & 9.73 & 13.86 & 4.13 \\
\hline $2 \mathrm{~A}$ & 36 & & 12.76 & 4.81 \\
\hline $2 \mathrm{~A}$ & 42 & 9.64 & 10.52 & 0.88 \\
\hline $2 \mathrm{~A}$ & 48 & 9.38 & 9.34 & -0.04 \\
\hline Average & & 8.56 & 12.30 & 3.75 \\
\hline \multicolumn{5}{|c|}{ Species: Control } \\
\hline $2 \mathrm{~B}$ & 6 & 9.42 & 8.07 & -1.35 \\
\hline $2 B$ & 12 & 7.56 & 11.98 & 4.41 \\
\hline $2 B$ & 18 & 11.18 & 14.23 & 3.05 \\
\hline $2 B$ & 24 & 11.85 & 14.78 & 2.93 \\
\hline 2B & 30 & 10.37 & 11.38 & 1.01 \\
\hline $2 \mathrm{~B}$ & 36 & 4.87 & 12.29 & \\
\hline $2 \mathrm{~B}$ & 42 & 9.49 & 10.08 & 0.59 \\
\hline $2 \mathrm{~B}$ & 48 & 9.31 & & \\
\hline Average & & 9.26 & 11.83 & 1.77 \\
\hline \multicolumn{5}{|c|}{ Species: Pocket Gopher } \\
\hline $2 \mathrm{C}$ & 6 & 6.92 & 9.49 & 2.57 \\
\hline $2 \mathrm{C}$ & 12 & 8.01 & 13.91 & 5.90 \\
\hline $2 \mathrm{C}$ & 18 & 9.08 & 14.83 & 5.76 \\
\hline $2 \mathrm{C}$ & 24 & 9.60 & 14.56 & 4.96 \\
\hline $2 C$ & 30 & 8.23 & 11.36 & 3.13 \\
\hline $2 C$ & 36 & 9.66 & & 1.77 \\
\hline $2 \mathrm{C}$ & 42 & 10.01 & 10.37 & 0.36 \\
\hline $2 C$ & 48 & 9.27 & 10.30 & 1.03 \\
\hline Average & & 8.85 & 12.03 & 3.18 \\
\hline
\end{tabular}


Table A-3. Soil Moisture Profile Changes During Third Test. (sheet 1 of 2)

\begin{tabular}{|c|c|c|c|c|}
\hline Box number & Depth (in.) & $\begin{array}{c}\text { Initial } \\
\text { moisture } \\
(\%) \\
\end{array}$ & $\begin{array}{c}\text { Ending } \\
\text { moisture } \\
(\%)\end{array}$ & $\begin{array}{l}\text { Percent } \\
\text { change }\end{array}$ \\
\hline \multicolumn{5}{|c|}{ Species: Townsend Ground Squirrel } \\
\hline $1 \mathrm{~A}$ & 6 & 15.38 & 7.47 & -7.91 \\
\hline $1 \mathrm{~A}$ & 12 & 14.25 & 9.79 & -4.46 \\
\hline$\overline{1 \mathrm{~A}}$ & 18 & 15.78 & 11.72 & -4.05 \\
\hline $1 \mathrm{~A}$ & 24 & 15.64 & 12.17 & -3.47 \\
\hline$\overline{1 A}$ & 30 & 16.62 & 12.93 & -3.70 \\
\hline $1 \mathrm{~A}$ & 36 & 17.52 & 13.73 & -3.79 \\
\hline $1 \mathrm{~A}$ & 42 & 17.20 & 13.02 & -4.18 \\
\hline $1 \mathrm{~A}$ & 48 & 18.39 & 13.65 & -4.74 \\
\hline $1 \mathrm{~A}$ & 54 & 18.95 & 12.35 & -6.60 \\
\hline Average & & 16.64 & 11.87 & -4.77 \\
\hline \multicolumn{5}{|c|}{ Species: Pocket Gopher } \\
\hline 1B & 6 & 17.01 & 8.74 & -8.27 \\
\hline $1 \mathrm{~B}$ & 12 & 14.04 & 9.57 & -4.47 \\
\hline $1 \mathrm{~B}$ & 18 & 14.24 & 10.57 & -3.67 \\
\hline $1 \mathrm{~B}$ & 24 & 15.11 & 12.13 & -2.98 \\
\hline $1 \mathrm{~B}$ & 30 & 15.38 & 12.43 & -2.94 \\
\hline $1 \mathrm{~B}$ & 36 & 16.65 & 13.82 & -2.83 \\
\hline $1 \mathrm{~B}$ & 42 & 16.85 & 13.70 & -3.15 \\
\hline $1 \mathrm{~B}$ & 48 & 17.32 & 12.26 & -5.06 \\
\hline 1B & 54 & 17.98 & 14.36 & -3.62 \\
\hline Average & & 16.07 & 11.96 & -4.11 \\
\hline \multicolumn{5}{|c|}{ Species: Control } \\
\hline $1 \mathrm{C}$ & 6 & 17.99 & 7.28 & -10.71 \\
\hline $1 \mathrm{C}$ & 12 & 15.97 & 10.53 & -5.44 \\
\hline $1 \mathrm{C}$ & 18 & 15.66 & 11.50 & -4.15 \\
\hline $1 \mathrm{C}$ & 24 & 16.46 & 12.40 & -4.06 \\
\hline $1 \mathrm{C}$ & 30 & 17.33 & 12.67 & -4.66 \\
\hline $1 \mathrm{C}$ & 36 & 17.80 & 12.66 & -5.14 \\
\hline $1 \mathrm{C}$ & 42 & 17.82 & 14.64 & -3.17 \\
\hline $1 \mathrm{C}$ & 48 & 18.69 & 13.67 & -5.02 \\
\hline $1 \mathrm{C}$ & 54 & 17.87 & 15.27 & -2.60 \\
\hline Average & & 17.29 & 12.29 & -5.00 \\
\hline
\end{tabular}


Table A-3. Soil Moisture Profile Changes During Third Test. (sheet 2 of 2)

\begin{tabular}{|c|c|c|c|c|}
\hline Box number & Depth (in.) & $\begin{array}{c}\text { Initial } \\
\text { moisture } \\
(\%)\end{array}$ & $\begin{array}{l}\text { Ending } \\
\text { moisture } \\
(\%)\end{array}$ & $\begin{array}{l}\text { Percent } \\
\text { change }\end{array}$ \\
\hline \multicolumn{5}{|c|}{ Species: Townsend Ground Squirrel } \\
\hline $2 A$ & 6 & 16.20 & 6.90 & -9.30 \\
\hline $2 \mathrm{~A}$ & 12 & 16.49 & 9.08 & -7.40 \\
\hline $2 \mathrm{~A}$ & 18 & 16.35 & 10.09 & -6.26 \\
\hline $2 \mathrm{~A}$ & 24 & 16.72 & 10.10 & -6.62 \\
\hline $2 A$ & 30 & 16.09 & 8.36 & -7.72 \\
\hline $2 \mathrm{~A}$ & 36 & 15.67 & 10.80 & -4.87 \\
\hline $2 \mathrm{~A}$ & 42 & 17.41 & 10.80 & -6.61 \\
\hline $2 A$ & 48 & 15.09 & 9.33 & -5.76 \\
\hline $2 \mathrm{~A}$ & 54 & 14.83 & 9.28 & -5.55 \\
\hline Average & & 16.09 & 9.42 & -6.68 \\
\hline \multicolumn{5}{|c|}{ Species: Pocket Gopher } \\
\hline $2 \mathrm{~B}$ & 6 & 15.56 & 6.19 & -9.37 \\
\hline $2 \mathrm{~B}$ & 12 & 15.83 & 7.64 & -8.19 \\
\hline $2 \mathrm{~B}$ & 18 & 16.91 & 9.99 & -6.91 \\
\hline $2 \mathrm{~B}$ & 24 & 19.73 & 12.19 & -7.54 \\
\hline $2 \mathrm{~B}$ & 30 & 18.32 & 4.87 & -13.45 \\
\hline $2 B$ & 36 & 16.55 & 9.07 & -7.48 \\
\hline $2 B$ & 42 & 15.05 & 10.83 & -4.22 \\
\hline $2 B$ & 48 & 16.46 & 10.12 & -6.34 \\
\hline $2 B$ & 54 & 17.36 & 12.05 & -5.31 \\
\hline Average & & 16.86 & 9.22 & -7.65 \\
\hline \multicolumn{5}{|c|}{ Species: Control } \\
\hline $2 \mathrm{C}$ & 6 & 15.28 & 5.69 & -9.58 \\
\hline $2 \mathrm{C}$ & 12 & 15.22 & 7.40 & -7.82 \\
\hline $2 \mathrm{C}$ & 18 & 15.26 & 10.41 & -4.85 \\
\hline $2 \mathrm{C}$ & 24 & 16.48 & 11.55 & -4.94 \\
\hline $2 \mathrm{C}$ & 30 & 17.88 & 11.67 & -6.21 \\
\hline $2 \mathrm{C}$ & 36 & 17.53 & 11.07 & -6.46 \\
\hline $2 \mathrm{C}$ & 42 & 17.58 & 11.53 & -6.05 \\
\hline $2 \mathrm{C}$ & 48 & 17.02 & 12.35 & -4.66 \\
\hline $2 \mathrm{C}$ & 54 & 18.90 & 13.50 & -5.40 \\
\hline Average & & 16.79 & 10.57 & -6.22 \\
\hline
\end{tabular}


Table A-4. Soil Moisture Profile Changes During Fourth Test. (sheet 1 of 2)

\begin{tabular}{|c|c|c|c|c|}
\hline Box number & Depth (in.) & $\begin{array}{c}\text { Initial } \\
\text { moisture } \\
(\%)\end{array}$ & $\begin{array}{c}\text { Ending } \\
\text { moisture } \\
(\%)\end{array}$ & $\begin{array}{l}\text { Percent } \\
\text { change }\end{array}$ \\
\hline \multicolumn{5}{|c|}{ Species: Gopher } \\
\hline $1 \mathrm{~A}$ & 6 & 8.64 & 11.89 & 3.24 \\
\hline $1 \mathrm{~A}$ & 12 & 9.38 & 11.92 & 2.54 \\
\hline $1 \mathrm{~A}$ & 18 & 9.86 & 12.93 & 3.07 \\
\hline $1 \mathrm{~A}$ & 24 & 9.69 & 10.45 & 0.76 \\
\hline $1 \mathrm{~A}$ & 30 & 9.86 & 10.64 & 0.78 \\
\hline $1 \mathrm{~A}$ & 36 & 10.31 & 11.08 & 0.77 \\
\hline $1 \mathrm{~A}$ & 42 & 10.93 & 11.23 & 0.30 \\
\hline $1 \mathrm{~A}$ & 48 & 11.34 & 11.67 & 0.33 \\
\hline $1 \mathrm{~A}$ & 54 & 10.62 & 10.99 & 0.37 \\
\hline Average & & 10.07 & 11.42 & 1.35 \\
\hline \multicolumn{5}{|c|}{ Species: Pocket Mouse } \\
\hline 1B & 6 & 7.52 & 14.12 & 6.59 \\
\hline 1B & 12 & 9.37 & 12.38 & 3.01 \\
\hline 1B & 18 & 9.11 & 11.79 & 2.68 \\
\hline 1B & 24 & 8.33 & 11.61 & 3.28 \\
\hline 1B & 30 & 9.63 & 11.63 & 2.00 \\
\hline 1B & 36 & 10.37 & 12.10 & 1.73 \\
\hline $1 \mathrm{~B}$ & 42 & 10.65 & 7.46 & -3.19 \\
\hline 1B & 48 & 9.57 & 10.34 & 0.77 \\
\hline 1B & 54 & 10.08 & 10.66 & 0.58 \\
\hline Average & & 9.41 & 11.34 & 1.94 \\
\hline \multicolumn{5}{|c|}{ Species: Control } \\
\hline $1 \mathrm{C}$ & 6 & 7.28 & 13.15 & 5.87 \\
\hline $1 \mathrm{C}$ & 12 & 10.53 & 13.42 & 2.88 \\
\hline $1 \mathrm{C}$ & 18 & 11.50 & 13.96 & 2.45 \\
\hline $1 \mathrm{C}$ & 24 & 12.40 & 13.95 & 1.55 \\
\hline $1 \mathrm{C}$ & 30 & 12.67 & 15.18 & 2.51 \\
\hline $1 \mathrm{C}$ & 36 & 12.66 & 15.42 & 2.76 \\
\hline $1 \mathrm{C}$ & 42 & 14.64 & 13.63 & -1.02 \\
\hline $1 \mathrm{C}$ & 48 & 13.67 & 15.06 & 1.39 \\
\hline $1 \mathrm{C}$ & 54 & 15.27 & 15.84 & 0.57 \\
\hline Average & & 12.29 & 14.40 & 2.11 \\
\hline
\end{tabular}


Table A-4. Soil Moisture Profile Changes During Fourth Test. (sheet 2 of 2)

\begin{tabular}{|c|c|c|c|c|}
\hline Box number & Depth (in.) & $\begin{array}{c}\text { Initial } \\
\text { moisture } \\
(\%)\end{array}$ & $\begin{array}{c}\text { Ending } \\
\text { moisture } \\
(\%)\end{array}$ & $\begin{array}{l}\text { Percent } \\
\text { change }\end{array}$ \\
\hline \multicolumn{5}{|c|}{ Species: Gopher } \\
\hline $2 \mathrm{~A}$ & 6 & 7.97 & 11.62 & 3.65 \\
\hline $2 \mathrm{~A}$ & 12 & 9.72 & 11.92 & 2.20 \\
\hline $2 \mathrm{~A}$ & 18 & 10.06 & 10.90 & 0.84 \\
\hline $2 \mathrm{~A}$ & 24 & 14.68 & 12.78 & -1.91 \\
\hline $2 \mathrm{~A}$ & 30 & 13.99 & 10.75 & -3.24 \\
\hline $2 \mathrm{~A}$ & 36 & 15.46 & 12.86 & -2.60 \\
\hline $2 \mathrm{~A}$ & 42 & 14.53 & 12.31 & -2.23 \\
\hline $2 \mathrm{~A}$ & 48 & 13.75 & 12.14 & -1.61 \\
\hline $2 \mathrm{~A}$ & 54 & 12.25 & & \\
\hline Average & & 12.49 & 11.91 & -0.61 \\
\hline \multicolumn{5}{|c|}{ Species: Pocket Mouse } \\
\hline $2 B$ & 6 & 8.99 & 12.09 & 3.09 \\
\hline $2 B$ & 12 & 10.21 & 12.90 & 2.70 \\
\hline $2 B$ & 18 & 9.32 & 12.10 & 2.78 \\
\hline $2 B$ & 24 & 10.35 & 12.42 & 2.07 \\
\hline $2 B$ & 30 & 11.24 & 12.33 & 1.09 \\
\hline $2 B$ & 36 & 12.37 & 12.11 & -0.25 \\
\hline $2 B$ & 42 & 12.82 & 12.55 & -0.27 \\
\hline $2 \mathrm{~B}$ & 48 & 12.69 & 11.87 & -0.82 \\
\hline $2 B$ & 54 & 12.06 & & \\
\hline Average & & 11.12 & 12.30 & 1.30 \\
\hline \multicolumn{5}{|c|}{ Species: Control } \\
\hline $2 \mathrm{C}$ & 6 & 5.69 & 10.94 & 5.24 \\
\hline $2 \mathrm{C}$ & 12 & 7.40 & 10.78 & 3.38 \\
\hline $2 \mathrm{C}$ & 18 & 10.41 & 12.87 & 2.47 \\
\hline $2 \mathrm{C}$ & 24 & 11.55 & 13.09 & 1.54 \\
\hline $2 \mathrm{C}$ & 30 & 11.67 & 13.27 & 1.60 \\
\hline $2 \mathrm{C}$ & 36 & 11.07 & 14.98 & 3.91 \\
\hline $2 \mathrm{C}$ & 42 & 11.53 & 11.27 & -0.25 \\
\hline $2 \mathrm{C}$ & 48 & 12.35 & 14.37 & 2.02 \\
\hline $2 \mathrm{C}$ & 54 & 13.50 & 14.47 & 0.98 \\
\hline Average & & 10.57 & 12.89 & 2.32 \\
\hline
\end{tabular}


Table A-5. Soil Moisture Profile Changes During Fifth Test. (sheet 1 of 2)

\begin{tabular}{|c|c|c|c|c|}
\hline Box number & Depth (in.) & $\begin{array}{c}\text { Initial } \\
\text { moisture } \\
(\%)\end{array}$ & $\begin{array}{c}\text { Ending } \\
\text { moisture } \\
(\%)\end{array}$ & $\begin{array}{l}\text { Percent } \\
\text { change }\end{array}$ \\
\hline \multicolumn{5}{|c|}{ Species: Townsend } \\
\hline $1 \mathrm{~A}$ & 6 & 15.08 & 5.62 & -9.45 \\
\hline $1 A$ & 12 & 14.70 & 7.40 & -7.31 \\
\hline $1 \mathrm{~A}$ & 18 & 16.90 & 9.37 & -7.54 \\
\hline $1 \mathrm{~A}$ & 24 & 14.56 & 10.37 & -4.20 \\
\hline $1 A$ & 30 & 14.68 & 12.16 & -2.52 \\
\hline $1 \mathrm{~A}$ & 36 & 15.98 & 12.37 & -3.61 \\
\hline $1 \mathrm{~A}$ & 42 & 15.28 & 11.83 & -3.44 \\
\hline $1 \mathrm{~A}$ & 48 & 14.24 & 10.60 & -3.64 \\
\hline Average & & 14.69 & 9.98 & -5.21 \\
\hline \multicolumn{5}{|c|}{ Species: Pocket Mouse } \\
\hline $1 B$ & 6 & 13.22 & 5.78 & -7.44 \\
\hline $1 \mathrm{~B}$ & 12 & 15.32 & 7.22 & -8.10 \\
\hline 1B & 18 & 17.71 & 10.15 & -7.56 \\
\hline $1 \mathrm{~B}$ & 24 & 14.63 & 10.45 & -4.18 \\
\hline $1 \mathrm{~B}$ & 30 & 14.00 & 9.23 & -4.77 \\
\hline $1 \mathrm{~B}$ & 36 & 16.37 & 12.22 & -4.15 \\
\hline $1 B$ & 42 & 12.31 & 12.67 & 0.36 \\
\hline $1 \mathrm{~B}$ & 48 & 14.34 & 12.06 & -2.28 \\
\hline Average & & 14.78 & 9.97 & -4.77 \\
\hline \multicolumn{5}{|c|}{ Species: Control } \\
\hline $1 C$ & 6 & 16.04 & 6.96 & -9.08 \\
\hline $1 \mathrm{C}$ & 12 & 16.69 & 8.61 & -8.09 \\
\hline $1 C$ & 78 & 15.24 & 10.59 & -4.65 \\
\hline $1 C$ & 24 & 17.08 & 10.63 & -6.45 \\
\hline $1 \mathrm{C}$ & 30 & 16.89 & 11.69 & -5.20 \\
\hline $1 C$ & 36 & & 10.42 & \\
\hline $1 C$ & 42 & 15.64 & 11.08 & -4.56 \\
\hline $1 C$ & 48 & 13.44 & 12.05 & -1.39 \\
\hline Average & & 12.29 & 14.40 & 2.11 \\
\hline
\end{tabular}


Table A-5. Soil Moisture Profile Changes During Fifth Test.

(sheet 2 of 2)

\begin{tabular}{|c|c|c|c|c|}
\hline Box number & Depth (in.) & $\begin{array}{c}\text { Initial } \\
\text { moisture } \\
(\%)\end{array}$ & $\begin{array}{l}\text { Ending } \\
\text { moisture } \\
(\%)\end{array}$ & $\begin{array}{l}\text { Percent } \\
\text { change }\end{array}$ \\
\hline \multicolumn{5}{|c|}{ Species: Townsend } \\
\hline $2 \mathrm{~A}$ & 6 & 12.62 & 4.66 & -7.96 \\
\hline $2 A$ & 12 & 13.32 & 4.43 & -8.89 \\
\hline $2 A$ & 18 & 13.86 & 7.27 & -6.59 \\
\hline $2 \mathrm{~A}$ & 24 & 13.42 & 8.31 & -5.11 \\
\hline $2 A$ & 30 & 13.80 & 9.62 & -4.18 \\
\hline $2 \mathrm{~A}$ & 36 & 14.51 & 9.31 & -5.20 \\
\hline $2 A$ & 42 & 13.84 & 6.94 & -6.90 \\
\hline $2 A$ & 48 & 12.52 & 7.72 & -4.80 \\
\hline Average & & 12.49 & 11.91 & -0.61 \\
\hline \multicolumn{5}{|c|}{ Species: Pocket Mouse } \\
\hline $2 \mathrm{~B}$ & 6 & 12.83 & 6.09 & -6.74 \\
\hline $2 B$ & 12 & 12.72 & 7.19 & -5.54 \\
\hline $2 B$ & 18 & 15.25 & 10.33 & -4.92 \\
\hline $2 B$ & 24 & 16.67 & 10.04 & -6.63 \\
\hline $2 B$ & 30 & 13.18 & 10.18 & -3.00 \\
\hline $2 B$ & 36 & 14.05 & 9.65 & -4.40 \\
\hline $2 B$ & 42 & 12.52 & 10.57 & -1.95 \\
\hline $2 \mathrm{~B}$ & 48 & 12.15 & 9.69 & -2.46 \\
\hline Average & & 13.59 & 9.22 & -4.45 \\
\hline \multicolumn{5}{|c|}{ Species: Control } \\
\hline $2 C$ & 6 & 15.74 & 5.46 & -10.28 \\
\hline $2 \mathrm{C}$ & 12 & 15.99 & 8.08 & -7.91 \\
\hline $2 C$ & 18 & 15.37 & 8.48 & -6.89 \\
\hline $2 C$ & 24 & 13.91 & 10.32 & -3.59 \\
\hline $2 C$ & 30 & 13.07 & 9.69 & -3.38 \\
\hline $2 \mathrm{C}$ & 36 & 12.17 & 9.42 & -2.75 \\
\hline $2 \mathrm{C}$ & 42 & 12.79 & 10.02 & -2.77 \\
\hline $2 C$ & 48 & 11.60 & 10.12 & -1.49 \\
\hline Average & & 13.73 & 8.95 & -4.88 \\
\hline
\end{tabular}


APPENDIX B

CONDUCTANCE AND HYDROPROBE DATA (COLLECTED FOR TESTS 1 THROUGH 5) 
Table B-2. Hydroprobe Readings Observed During Test Two. (sheet 1 of 6)

\begin{tabular}{|c|c|c|c|c|c|c|c|c|c|c|}
\hline Nov $88-A p$ & & NOV 18 & DEC8 & JAN5 & JAN31 & MAR10 & MAR20 & MAR28 & APR7 & APR12 \\
\hline BOX 1A PG & DEPTH & & & & & & & & & \\
\hline \multirow[t]{6}{*}{ PROBE 11} & 5 & 3591 & 3243 & 3195 & 2158 & 3531 & 2969 & 2943 & 2003 & 2467 \\
\hline & 11 & 4782 & 4091 & 4896 & 4283 & 8223 & 7529 & 6668 & 5394 & 5127 \\
\hline & 17 & 4589 & 4194 & 4467 & 4447 & 7692 & 7428 & 7110 & 5750 & 5358 \\
\hline & 23 & 4556 & 4537 & 4942 & 4519 & 6101 & 7363 & 7070 & 6406 & 6181 \\
\hline & 29 & 4622 & 4371 & 4647 & 4465 & 4598 & 5940 & 6193 & 6097 & 6338 \\
\hline & 35 & 4704 & 4421 & 4719 & 4594 & 4689 & 4878 & 5207 & 5365 & 5625 \\
\hline $\mathrm{BOX} 1 \mathrm{~A} P G$ & DEPTH & & & & & & & & & \\
\hline \multirow[t]{6}{*}{ PROBE 12} & 5 & 3750 & 2185 & 3730 & 1764 & 5172 & 2857 & 3746 & 2740 & 2780 \\
\hline & 11 & 4550 & 4365 & 4766 & 4326 & 9032 & 8034 & 7010 & 5942 & 5490 \\
\hline & 17 & 4486 & 4314 & 4291 & 4348 & 8826 & 8379 & 7542 & 6896 & 6462 \\
\hline & 23 & 4208 & 4254 & 4456 & 4331 & 7379 & 7669 & 7505 & 7001 & 6601 \\
\hline & 29 & 4050 & 4155 & 4327 & 4318 & 5672 & 6236 & 6213 & 6246 & 6234 \\
\hline & 35 & 4229 & 4412 & 4285 & 4179 & 4468 & 4731 & 4996 & 5209 & 5403 \\
\hline $\mathrm{BOX} 1 \mathrm{~A} P G$ & DEPTH & & & & & & & & & \\
\hline \multirow[t]{6}{*}{ AVERAGE } & 5 & 3671 & 2714 & 3463 & 1961 & 4352 & 2913 & 3345 & 2372 & 2624 \\
\hline & 11 & 4666 & 4228 & 4831 & 4305 & 8628 & 7782 & 6839 & 5668 & 5309 \\
\hline & 17 & 4538 & 4254 & 4379 & 4398 & 8259 & 7904 & 7326 & 6323 & 5910 \\
\hline & 23 & 4382 & 4396 & 4699 & 4425 & 6740 & 7516 & 7288 & 6704 & 6391 \\
\hline & 29 & 4336 & 4263 & 4487 & 4392 & 5135 & 6088 & 6203 & 6172 & 6286 \\
\hline & 35 & 4467 & 4417 & 4502 & 4387 & 4579 & 4805 & 5102 & 5287 & 5514 \\
\hline
\end{tabular}


Table B-2. Hydroprobe Readings Observed During Test Two. (sheet 2 of 6)

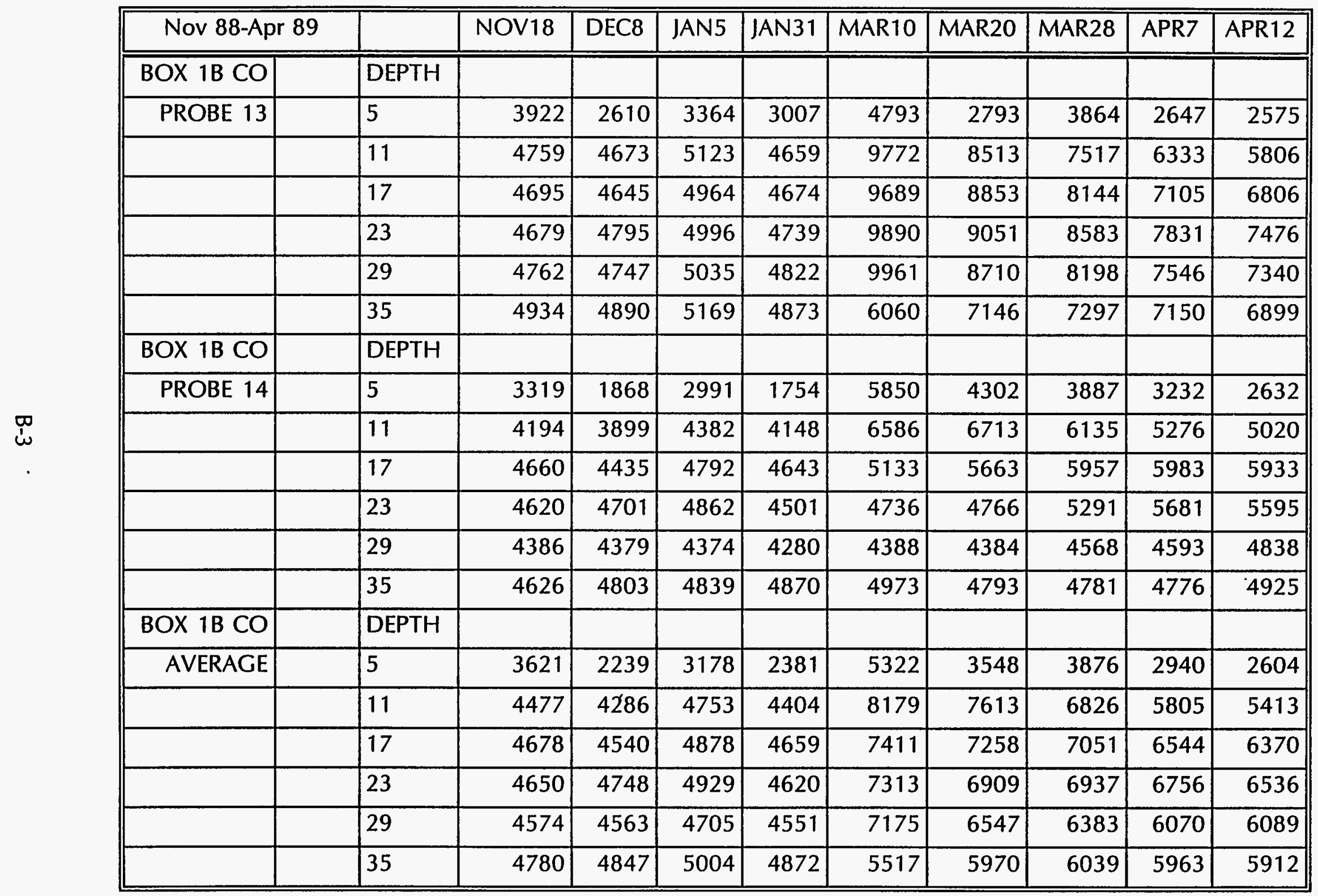


Table B-2. Hydroprobe Readings Observed During Test Two. (sheet 3 of 6)

\begin{tabular}{|c|c|c|c|c|c|c|c|c|c|c|}
\hline Nov 88-Ap & & NOV18 & DEC8 & JAN5 & JAN31 & MAR10 & MAR20 & MAR28 & APR7 & APR12 \\
\hline $\mathrm{BOX} 1 \mathrm{CPM}$ & DEPTH & & & & & & & & & \\
\hline \multirow[t]{6}{*}{ PROBE 15 } & 5 & 2858 & 3513 & 3348 & 2641 & 5987 & 3874 & 4718 & 3321 & 1678 \\
\hline & 11 & 4424 & 4537 & 4670 & 4581 & 9148 & 8141 & 7477 & 6077 & 5208 \\
\hline & 17 & 4271 & 4298 & 4510 & 4492 & 8339 & 8239 & 7468 & 6616 & 6258 \\
\hline & 23 & 4652 & 4362 & 4404 & 4383 & 5369 & 7059 & 7060 & 6561 & 6444 \\
\hline & 29 & 4442 & 4562 & 4604 & 4503 & 4696 & 6142 & 6563 & 6220 & 6196 \\
\hline & 35 & 4772 & 4920 & 4987 & 4680 & 5009 & 5091 & 5595 & 5683 & 5716 \\
\hline $\mathrm{BOX} 1 \mathrm{C} \mathrm{PM}$ & DEPTH & & & & & & & & & \\
\hline \multirow[t]{6}{*}{ PROBE 16} & 5 & 3019 & 3163 & 3194 & 2674 & 6740 & 3601 & 3288 & 2593 & 2862 \\
\hline & 11 & 4257 & 4204 & 4190 & 4041 & 8184 & 7442 & 6622 & 5920 & 5690 \\
\hline & 17 & 4685 & 4648 & 4610 & 4448 & 7895 & 8130 & 7558 & 7257 & 7036 \\
\hline & 23 & 4657 & 4597 & 4702 & 4698 & 5446 & 7030 & 7113 & 6775 & 6600 \\
\hline & 29 & 4569 & 4555 & 4722 & 4557 & 4586 & 5352 & 5711 & 5939 & 6080 \\
\hline & 35 & 4753 & 4808 & 4589 & 4642 & 4739 & 4567 & 4836 & 5188 & 5313 \\
\hline $\mathrm{BOX} 1 \mathrm{C} \mathrm{PM}$ & DEPTH & & & & & & & & & \\
\hline \multirow[t]{7}{*}{ AVERAGE } & 5 & 2939 & 3338 & 3271 & 2658 & 6364 & 3738 & 4003 & 2957 & 2270 \\
\hline & 11 & 4341 & 4371 & 4430 & 4311 & 8666 & 7792 & 7050 & 5999 & 5449 \\
\hline & 17 & 4478 & 4473 & 4560 & 4470 & 8117 & 8185 & 7513 & 6937 & 6647 \\
\hline & 23 & 4655 & 4480 & 4553 & 4541 & 5408 & 7045 & 7087 & 6668 & 6522 \\
\hline & 29 & 4506 & 4559 & 4663 & 4530 & 4641 & 5747 & 6137 & 6080 & 6138 \\
\hline & 35 & 4763 & 4864 & 4788 & 4661 & 4874 & 4829 & 5216 & 5436 & 5515 \\
\hline & & NOV18 & DEC8 & JAN5 & JAN31 & MAR10 & MAR20 & MAR28 & APR7 & APR12 \\
\hline
\end{tabular}


Table B-2. Hydroprobe Readings Observed During Test Two. (sheet 4 of 6)

\begin{tabular}{|c|c|c|c|c|c|c|c|c|c|c|}
\hline Nov 88-Ap & & NOV18 & DEC8 & JAN5 & JAN31 & MAR10 & MAR20 & MAR 28 & APR7 & APR12 \\
\hline BOX 2A PG & DEPTH & & & & & & & & & \\
\hline PROBE 21 & 5 & 2363 & 3208 & 4357 & 2141 & 4798 & 3349 & 3397 & 3176 & 1742 \\
\hline & 11 & 4178 & 4058 & 4183 & 4150 & 8238 & 7379 & 6586 & 5744 & 4845 \\
\hline & 17 & 4351 & 4454 & 4394 & 4326 & 7526 & 7562 & 7122 & 6458 & 6316 \\
\hline & 23 & 4690 & 4575 & 4375 & 4561 & 5271 & 6874 & 6758 & 6547 & 6643 \\
\hline & 29 & 4614 & 4491 & 4101 & 4401 & 4778 & 5462 & 5976 & 6114 & 6187 \\
\hline & 35 & 4337 & 4412 & 4234 & 4496 & 4730 & 4690 & 4990 & 5362 & 5413 \\
\hline BOX 2A PG & DEPTH & & & & & & & & & \\
\hline PROBE 22 & 5 & 2952 & 1879 & 2769 & 2524 & 8133 & 5963 & 5366 & 3683 & 3763 \\
\hline & 11 & 3250 & 2803 & 2945 & 2975 & 8225 & 7315 & 6291 & 5435 & 4935 \\
\hline & 17 & 3213 & 2984 & 2896 & 3022 & 6120 & 6215 & 5724 & 5354 & 5190 \\
\hline & 23 & 4076 & 3963 & 3973 & 4000 & 4392 & 4773 & 5049 & 5437 & 5499 \\
\hline & 29 & 4631 & 4212 & 4465 & 4409 & 4520 & 4525 & 5047 & 5298 & 5454 \\
\hline & 35 & 4386 & 3961 & 4094 & 4112 & 4231 & 4425 & 4382 & 4529 & 4686 \\
\hline $\mathrm{BOX} 2 \mathrm{~A}$ PG & DEPTH & & & & & & & & & \\
\hline AVERAGE & 5 & 2658 & 2544 & 3563 & 2333 & 6466 & 4656 & 4382 & 3430 & 2753 \\
\hline & 11 & 3714 & 3431 & 3564 & 3563 & 8232 & 7347 & 6439 & 5590 & 4890 \\
\hline & 17 & 3782 & 3719 & 3645 & 3674 & 6823 & 6889 & 6423 & 5906 & 5753 \\
\hline & 23 & 4383 & 4269 & 4174 & 4281 & 4832 & 5824 & 5904 & 5992 & 6071 \\
\hline & 29 & 4623 & 4352 & 4283 & 4405 & 4649 & 4994 & 5512 & 5706 & 5821 \\
\hline & 35 & 4362 & 4187 & 4164 & 4304 & 4481 & 4558 & 4686 & 4946 & 5050 \\
\hline
\end{tabular}


Table B-2. Hydroprobe Readings Observed During Test Two. (sheet 5 of 6)

\begin{tabular}{|c|c|c|c|c|c|c|c|c|c|c|c|}
\hline Nov 88-Ap & 89 & & NOV 18 & DEC8 & JAN5 & JAN31 & MAR10 & MAR20 & MAR 28 & APR7 & APR12 \\
\hline $\mathrm{BOX} 2 \mathrm{~B} \mathrm{CO}$ & & DEPTH & & & & & & & & & \\
\hline PROBE 23 & & 5 & 4085 & 4195 & 4360 & 4040 & 5440 & 4452 & 5612 & 4096 & 3696 \\
\hline & & 11 & 4862 & 5065 & 5595 & 5388 & 9590 & 8484 & 7733 & 6825 & 6526 \\
\hline & & 17 & 5220 & 5133 & 5549 & 5291 & 8767 & 8442 & 8002 & 7366 & 7002 \\
\hline & & 23 & 5109 & 5028 & 5169 & 5046 & 6288 & 7744 & 7408 & 7126 & 6858 \\
\hline & & 29 & 4747 & 4999 & 5002 & 4947 & 5322 & 6813 & 7038 & 6912 & 6793 \\
\hline & & 35 & 5140 & 5275 & 5121 & 5047 & 5199 & 5976 & 6697 & 6708 & 6820 \\
\hline $\mathrm{BOX} 2 \mathrm{~B} \mathrm{CO}$ & & DEPTH & & & & & & & & & \\
\hline PROBE 24 & & 5 & 3691 & 3652 & 3301 & 2679 & 7177 & 3520 & 5206 & 3329 & 3218 \\
\hline & & 11 & 4007 & 4148 & 4479 & 4349 & 10351 & 8843 & 7633 & 6811 & 6556 \\
\hline & & 17 & 4847 & 4750 & 4831 & 4704 & 11419 & 9418 & 8466 & 7950 & 7596 \\
\hline & & 23 & 5014 & 5140 & 5430 & 5010 & 8301 & 8502 & 8054 & 7707 & 7620 \\
\hline & & 29 & 4612 & 4694 & 4669 & 4752 & 6336 & 6600 & 6739 & 6673 & 6615 \\
\hline & & 35 & 4932 & 4897 & 4696 & 4748 & 5394 & 5101 & 5369 & 5913 & 5886 \\
\hline $\mathrm{BOX} 2 \mathrm{~B} \mathrm{CO}$ & & DEPTH & & & & & & & & & \\
\hline AVERAGE & & 5 & 3888 & 3924 & 3831 & 3360 & 6309 & 3986 & 5409 & 3713 & 3457 \\
\hline & & 11 & 4435 & 4607 & 5037 & 4869 & 9971 & 8664 & 7683 & 6818 & 6541 \\
\hline & & 17 & 5034 & 4942 & 5190 & 4998 & 10093 & 8930 & 8234 & 7658 & 7299 \\
\hline & & 23 & 5062 & 5084 & 5300 & 5028 & 7295 & 8123 & 7731 & 7417 & 7239 \\
\hline & & 29 & 4680 & 4847 & 4836 & 4850 & 5829 & 6707 & 6889 & 6793 & 6704 \\
\hline & & 35 & 5036 & 5086 & 4909 & 4898 & 5297 & 5539 & 6033 & 6311 & 6353 \\
\hline
\end{tabular}




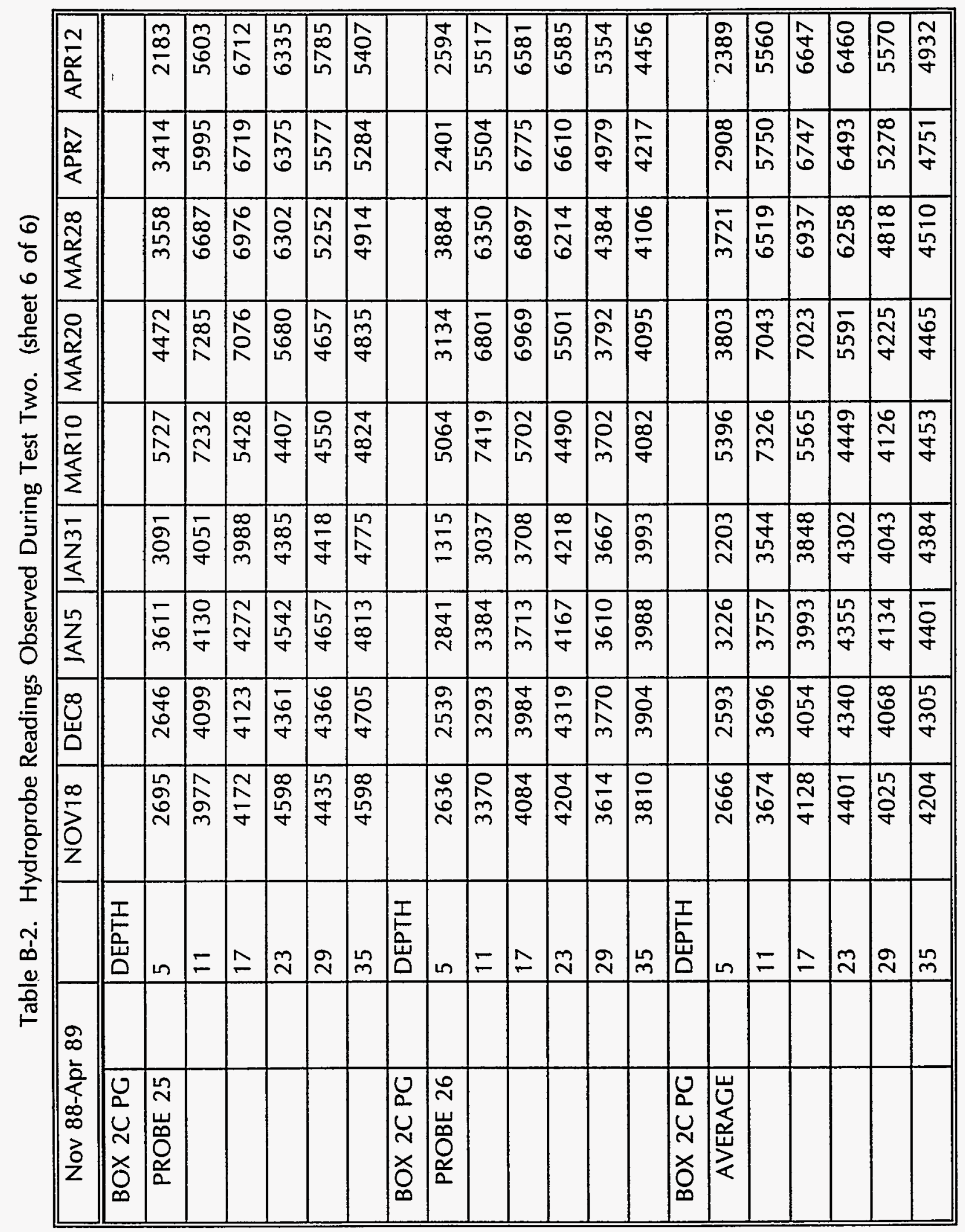


Table B-3. Hydroprobe Readings Observed During Test Three. (sheet 1 of 9)

\begin{tabular}{|c|c|c|c|c|c|c|c|c|c|c|c|}
\hline MAY23 & JUN12 & JUN18 & JUN20 & JUN28 & JULY5 & JUL19 & JUL26 & AUG16 & AUG18 & AUG24 & \\
\hline & & & & & & & & & & & \\
\hline 6881 & 5100 & 5322 & 5684 & 5246 & 5235 & 5320 & 5071 & 4629 & 5591 & 5048 & \\
\hline 7545 & 6619 & 6682 & 6699 & 6522 & 6506 & 6776 & 6612 & 6045 & 6052 & 6368 & \\
\hline 7464 & 6968 & 7078 & 6886 & 6963 & 6728 & 7195 & 6551 & 6321 & 6272 & 6509 & \\
\hline 7751 & 7575 & 7637 & 7451 & 7397 & 7483 & 7836 & 7318 & 6912 & 7031 & 7055 & \\
\hline 8596 & 8297 & 8459 & 8234 & 8191 & 8326 & 8720 & 8150 & 7666 & 7730 & 7944 & \\
\hline 8613 & 8417 & 8160 & 8283 & 8119 & 8106 & 8515 & 7846 & 7639 & 7523 & 7582 & \\
\hline 9049 & 8850 & 8833 & 8634 & 8806 & 8849 & 9449 & 8421 & 7994 & 7841 & 7987 & \\
\hline 10321 & 9798 & 9814 & 9686 & 9780 & 9939 & 10305 & 9445 & 9160 & 9266 & 9207 & \\
\hline 11305 & 11063 & 10804 & 10961 & 10886 & 10809 & 11301 & 11509 & 9842 & 10113 & 9828 & \\
\hline & & & & & & & & & & & \\
\hline 6411 & 4490 & 4946 & 4588 & 4030 & 3406 & 3142 & 3221 & 2706 & 3642 & 3171 & \\
\hline 6822 & 6104 & 5958 & 5879 & 5283 & 5014 & 5114 & 4947 & 4499 & 5115 & 4989 & \\
\hline 6803 & 6391 & 6377 & 6213 & 6198 & 6020 & 6351 & 5982 & 5604 & 5881 & 5719 & \\
\hline 6630 & 6528 & 6478 & 6341 & 6396 & 6402 & 6483 & 6085 & 5942 & 5970 & 6027 & \\
\hline 7712 & 7428 & 7344 & 7341 & 7319 & 7290 & 7501 & 7167 & 6654 & 6747 & 6796 & \\
\hline 7618 & 7717 & 7677 & 7622 & 7469 & 7425 & 7076 & 6683 & 6294 & 6363 & 6149 & \\
\hline 7912 & 7631 & 7699 & 7744 & 7711 & 7423 & 7618 & 7226 & 6752 & 6817 & 6762 & \\
\hline 8893 & 8680 & 8746 & 8743 & 8618 & 8644 & 8732 & 8300 & 7952 & 7959 & 7972 & \\
\hline 9504 & 9494 & 9222 & 9235 & 9041 & 9083 & 9349 & 8923 & 8341 & 8467 & 8421 & \\
\hline
\end{tabular}




\begin{tabular}{|c|c|c|c|c|c|c|c|c|c|c|c|c|c|c|c|c|c|c|c|c|}
\hline & & 0 & 0 & 0 & 0 & 0 & 0 & 0 & 0 & 0 & & & & & & & & & & \\
\hline 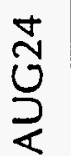 & & $\frac{0}{\frac{7}{7}}$ & 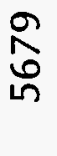 & $\frac{\sigma}{6}$ & $\underset{5}{5}$ & 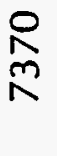 & $\begin{array}{l}0 \\
0 \\
\infty \\
0\end{array}$ & $\stackrel{n}{n}$ & $\begin{array}{l}8 \\
\text { 을 } \\
\infty\end{array}$ & $\frac{n}{\sigma}$ & & 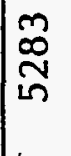 & $\begin{array}{l}\hat{\sigma} \\
\text { రु }\end{array}$ & $\frac{0}{0}$ & $\mid \begin{array}{c}0 \\
0 \\
0\end{array}$ & $\underset{N}{\stackrel{m}{N}}$ & $\begin{array}{l}n \\
\tilde{n} \\
\end{array}$ & $\begin{array}{l}\infty \\
m \\
m\end{array}$ & $\frac{1}{\infty}$ & $\stackrel{10}{\infty}$ \\
\hline$\frac{\infty}{\varrho}$ & & $\frac{N}{0}$ & 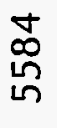 & Nô & 윰 & 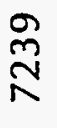 & $\underset{\mathscr{J}}{\tilde{\sigma}}$ & $\underset{N}{\stackrel{D}{N}}$ & $\frac{m}{\infty}$ & $\begin{array}{l}\text { নू } \\
\text { ুิ }\end{array}$ & & 自 & $\frac{5}{6}$ & 竎 & 号 & $\begin{array}{l}\text { 은 } \\
\text { N̦}\end{array}$ & 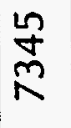 & $\stackrel{\stackrel{N}{N}}{N}$ & $\frac{N}{\infty}$ & 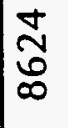 \\
\hline$\frac{0}{3}$ & & 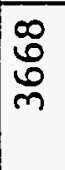 & $\begin{array}{c}N \\
\text { Nิ } \\
\text { กิ }\end{array}$ & mo & ปิ & $\begin{array}{l}\frac{0}{6} \\
\frac{1}{1}\end{array}$ & ڤ్ & $\stackrel{m}{n}$ & $\begin{array}{l}\mathfrak{L}_{1} \\
1 \\
\infty\end{array}$ & ๙ั) & & $\hat{m}$ & $\begin{array}{l}\infty \\
\text { In } \\
0 \\
0\end{array}$ & 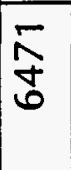 & 告 & $\begin{array}{l}\infty \\
\stackrel{\infty}{n} \\
\end{array}$ & $\frac{N}{\pi}$ & 䍃 & $\underset{\infty}{\stackrel{్}{\infty}}$ & $\begin{array}{l}0 \\
\infty \\
+ \\
\infty\end{array}$ \\
\hline 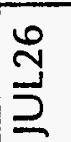 & & $\frac{6}{8}$ & $\begin{array}{l}\stackrel{8}{\infty} \\
\text { 年 }\end{array}$ & 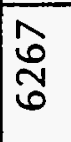 & フู & 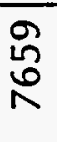 & $\begin{array}{l}\text { in } \\
\stackrel{0}{N} \\
N\end{array}$ & $\underset{\sim}{ \pm}$ & $\underset{\substack{\infty \\
\infty}}{m}$. & $\frac{0}{\grave{N}}$ & & $\begin{array}{l}0 \\
\text { ஸூ } \\
\text { ம้ }\end{array}$ & $\begin{array}{l}\mathcal{N} \\
\text { \%ె } \\
\tilde{\sigma}\end{array}$ & $\begin{array}{l}J \\
0 \\
0 \\
0\end{array}$ & 志 & 总 & $\begin{array}{l} \\
\text { 告 } \\
\end{array}$ & $\stackrel{m}{\stackrel{N}{N}}$ & న̂̀ & б్ \\
\hline$\stackrel{a}{\Xi}$ & & $\stackrel{\check{m}}{\stackrel{\sim}{\forall}}$ & 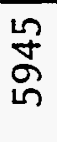 & $\frac{n}{\hat{n}}$ & $\frac{8}{1}$ & $\frac{\bar{\sigma}}{\infty}$ & مू & 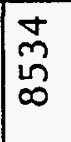 & $\frac{\sigma}{6}$ & 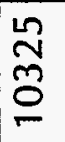 & & N & ช్ & $\begin{array}{l}\hat{N} \\
\infty \\
0\end{array}$ & $\begin{array}{l}\mathscr{\sigma} \\
\infty \\
\sigma \\
\sigma\end{array}$ & $\frac{\infty}{\pi}$ & $\begin{array}{l}m \\
\infty \\
\infty \\
N\end{array}$ & $\begin{array}{l}\mathcal{N} \\
N\end{array}$ & $\underset{\infty}{\bar{j}}$ & $\frac{\pi}{\sigma}$ \\
\hline$\frac{10}{2}$ & & $\underset{\tilde{n}}{\tilde{v}}$ & 号 & 雍 & ஜூ & 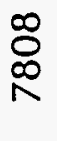 & $\frac{0}{N}$ & $\frac{m}{\infty}$ & $\begin{array}{l}\text { ปั } \\
\text { ลั }\end{array}$ & $\begin{array}{l}\text { o } \\
\text { ò }\end{array}$ & & $\begin{array}{l}\infty \\
\\
\text { in }\end{array}$ & 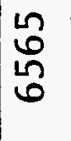 & $\begin{array}{l}\bar{\infty} \\
\infty \\
\infty \\
0\end{array}$ & m & 渠 & $\stackrel{N}{N}$ & $\begin{array}{l}\hat{\sigma} \\
\stackrel{N}{N}\end{array}$ & $\tilde{m}_{\infty}$ & $\begin{array}{l}\infty \\
0 \\
0\end{array}$ \\
\hline 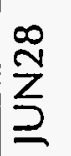 & & $\begin{array}{l}\infty \\
m \\
0 \\
+\end{array}$ & 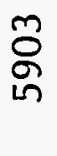 & $\begin{array}{l}\bar{\infty} \\
\tilde{\omega}\end{array}$ & 今్ & $\stackrel{\sim}{N}$ & 玄 & 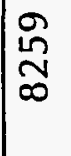 & $\frac{\sigma}{\sigma}$ & $\begin{array}{l}\text { பே } \\
\text { Бे }\end{array}$ & & $\underset{m}{\tilde{m}}$ & $\begin{array}{l}0 \\
\text { ஸึ } \\
0\end{array}$ & $\begin{array}{l}\infty \\
\infty \\
\infty\end{array}$ & $\begin{array}{l}n \\
\text { \% } \\
\text { g }\end{array}$ & $\stackrel{m}{\sim}$ & $\frac{N}{\infty}$ & $\bar{\kappa}$ & $\begin{array}{l}\forall \\
\stackrel{్}{\circ} \\
\infty\end{array}$ & O \\
\hline 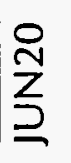 & & $\frac{0}{n}$ & 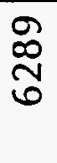 & $\begin{array}{l}0 \\
12 \\
102 \\
0\end{array}$ & $\begin{array}{l}0 \\
8 \\
0 \\
0\end{array}$ & $\begin{array}{l}\infty \\
\infty \\
N\end{array}$ & $\begin{array}{l}m \\
\text { L } \\
N\end{array}$ & $\begin{array}{l}\infty \\
\infty \\
\infty\end{array}$ & $\frac{10}{\sigma}$ & $\begin{array}{l}\infty \\
\stackrel{\infty}{\circ} \\
8 \\
\end{array}$ & & $\frac{\overline{1}}{\infty}$ & 离 & $\begin{array}{l}\hat{\infty} \\
0 \\
0\end{array}$ & m & $\begin{array}{l}\infty \\
\infty \\
1 \\
\\
\wedge\end{array}$ & $\begin{array}{l}8 \\
N\end{array}$ & 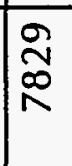 & $\frac{\text { ㄴ }}{\frac{8}{8}}$ & ñ \\
\hline$\stackrel{\infty}{\underset{Z}{Z}}$ & & $\frac{\dot{m}}{n}$ & 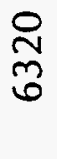 & 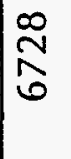 & $\begin{array}{l}\infty \\
\stackrel{0}{0} \\
0\end{array}$ & 용 & $\frac{\sigma}{\sigma}$ & $\begin{array}{l}\mathscr{0} \\
\stackrel{N}{\infty}\end{array}$ & 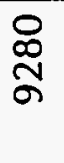 & $\frac{m}{8}$ & & \begin{tabular}{l}
$\infty$ \\
in \\
\multirow{1}{*}{}
\end{tabular} & $\frac{5}{6}$ & $\frac{0}{\tilde{y}}$ & $\begin{array}{l}0 \\
\text { m } \\
0\end{array}$ & ๙ั & $\frac{N}{N}$ & 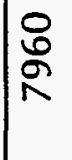 & 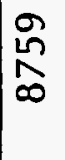 & $\begin{array}{l}0 \\
\text { in } \\
\text { ô }\end{array}$ \\
\hline$\frac{N}{z}$ & & $\stackrel{n}{\Omega}$ & $\begin{array}{r}\text { ֶै } \\
\text { ెु }\end{array}$ & $\begin{array}{l}0 \\
0 \\
0 \\
0\end{array}$ & $\begin{array}{l}\text { No } \\
\text { ํํㅇ } \\
\text { R }\end{array}$ & $\begin{array}{l}\text { ڤ్ } \\
\infty \\
\mathbb{N}\end{array}$ & $\begin{array}{l}1 \\
0 \\
0\end{array}$ & $\underset{\infty}{\bar{\Sigma}}$ & $\begin{array}{c}\text { ले } \\
\text { ू̆ }\end{array}$ & 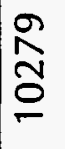 & & $\mid \begin{array}{l}0 \\
\\
10\end{array}$ & 占 & $\begin{array}{l}0 \\
\text { } \\
0 \\
0\end{array}$ & $\frac{\tilde{m}}{\bar{n}}$ & 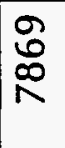 & $\begin{array}{l}0 \\
m \\
\infty\end{array}$ & $\begin{array}{l}0 \\
m \\
\infty \\
N\end{array}$ & $\frac{\bar{m}}{\sigma}$ & $\frac{m}{\sigma}$ \\
\hline$\frac{m}{j}$ & & ర̛⿱ & $\frac{⿱}{\infty}$ & $\frac{\dot{m}}{\pi}$ & $\frac{\pi}{\pi}$ & $\frac{\nabla}{\infty}$ & $\frac{0}{\infty}$ & $\begin{array}{l}\infty \\
+ \\
\infty\end{array}$ & ) & $\begin{array}{l}\text { 농 } \\
\text { fo } \\
0\end{array}$ & & $\underset{\delta}{\dot{\delta}}$ & N & $\begin{array}{l}\text { in } \\
\text { in } \\
N\end{array}$ & \begin{tabular}{l}
$n$ \\
$\infty$ \\
\multirow{N}{*}{}
\end{tabular} & $\frac{N}{n}$ & $\underset{\mathbb{J}}{ \pm}$ & 号 & 용 & 용 \\
\hline & $\frac{I}{\frac{I}{n}}$ & o. & $\stackrel{v}{-}$ & $\stackrel{\infty}{-}$ & $\stackrel{ \pm}{\sim}$ & in & $\stackrel{0}{m}$ & $\underset{f}{\mathscr{f}}$ & $\stackrel{\infty}{q}$ & in & $\frac{I}{\frac{I}{0}}$ & 0 & $\stackrel{v}{\sim}$ & $\stackrel{\infty}{\infty}$ & 芯 & 요 & m & $\stackrel{\sim}{\forall}$ & $\stackrel{\infty}{q}$ & เั \\
\hline $\begin{array}{l}\infty \\
\infty \\
20\end{array}$ & 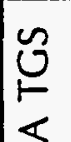 & 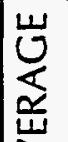 & & & & & & & & & $\begin{array}{l}\underline{Q} \\
\infty \\
\varrho\end{array}$ & $\frac{m}{m}$ & & & & & & & & \\
\hline$\sum_{\frac{1}{2}}^{\frac{1}{2}}$ & ○ & $1 \geq$ & & & & & & & & & 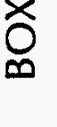 & $\frac{\alpha}{\alpha}$ & & & & & & & & \\
\hline
\end{tabular}


Table B-3. Hydroprobe Readings Observed During Test Three. (sheet 3 of 9)

\begin{tabular}{|c|c|c|c|c|c|c|c|c|c|c|c|c|c|}
\hline May-Aug 89 & & MAY23 & JUN12 & JUN18 & JUN20 & JUN28 & JULY5 & JUL19 & JUL26 & AUG16 & AUG 18 & AUG24 & \\
\hline $\mathrm{BOX} 1 \mathrm{~B} P \mathrm{PG}$ & DEPTH & & & & & & & & & & & & \\
\hline PROBE 14 & 6 & 7019 & 5357 & 5294 & 5385 & 5303 & 5163 & 5077 & 5006 & 4376 & 4874 & 4737 & \\
\hline & 12 & 6919 & 6248 & 6195 & 6029 & 5987 & 6035 & 6052 & 5866 & 5360 & 5430 & 5273 & \\
\hline & 18 & 7074 & 6522 & 6476 & 6480 & 6542 & 6433 & 6423 & 6026 & 5739 & 5767 & 5633 & \\
\hline & 24 & 7058 & 6981 & 6830 & 7056 & 6906 & 6821 & 6751 & 6187 & 6334 & 6414 & 6225 & \\
\hline & 30 & 7331 & 6910 & 7092 & 7134 & 6929 & 6899 & 6985 & 6853 & 6784 & 6702 & 6827 & \\
\hline & 36 & 7831 & 7917 & 7712 & 7746 & 7829 & 7645 & 7931 & 7706 & 7578 & 7508 & 7474 & \\
\hline & 42 & 7962 & 8042 & 7960 & 7881 & 8037 & 8007 & 7967 & 7871 & 7426 & 7516 & 7429 & \\
\hline & 48 & 8851 & 8720 & 8759 & 8570 & 8776 & 8647 & 8840 & 8525 & 8250 & 8407 & 8167 & \\
\hline & 54 & 9758 & 9572 & 9570 & 9460 & 9375 & 9375 & 9468 & 9148 & 8854 & 8886 & 8904 & \\
\hline $\mathrm{BOX} 1 \mathrm{~B}$ PG & DEPTH & & & & & & & & & & & & \\
\hline AVERAGE & 6 & 7030 & 5517 & 5376 & 5598 & 5323 & 5221 & 5500 & 5318 & 4657 & 5184 & 5010 & 0 \\
\hline & 12 & 7198 & 6447 & 6195 & 6262 & 6322 & 6300 & 6327 & 6129 & 5709 & 5771 & 5770 & 0 \\
\hline & 18 & 7215 & 6744 & 6476 & 6584 & 6712 & 6657 & 6650 & 6415 & 6105 & 6156 & 6122 & 0 \\
\hline & 24 & 7272 & 7057 & 6830 & 7075 & 6951 & 6862 & 6870 & 6571 & 6395 & 6530 & 6464 & 0 \\
\hline & 30 & 7742 & 7390 & 7092 & 7361 & 7181 & 7175 & 7352 & 7207 & 7071 & 6981 & 7150 & 0 \\
\hline & 36 & 7928 & 7877 & 7712 & 7753 & 7821 & 7689 & 7907 & 7630 & 7495 & 7427 & 7420 & 0 \\
\hline & 42 & 8029 & 7939 & 7960 & 7855 & 7979 & 7802 & 7795 & 7537 & 7499 & 7371 & 7384 & 0 \\
\hline & 48 & 8961 & 8926 & 8759 & 8793 & 8880 & 8492 & 8591 & 8301 & 8225 & 8290 & 8162 & 0 \\
\hline & 54 & 9925 & 9593 & 4785 & 9518 & 9412 & 9227 & 9303 & 8920 & 8670 & 8755 & 8790 & 0 \\
\hline
\end{tabular}


Table B-3. Hydroprobe Readings Observed During Test Three. (sheet 4 of 9)

\begin{tabular}{|r|l|l|r|r|r|r|r|r|r|r|r|r|r||}
\hline \hline May-Aug 89 & & MAY23 & JUN12 & JUN18 & JUN20 & JUN28 & JULY5 & JUL19 & JUL26 & AUG16 & AUG18 & AUG24 \\
\hline \hline BOX 1C CO & DEPTH & & & & & & & & & & & & \\
\hline PROBE 15 & 6 & 7261 & 5379 & 5361 & 5578 & 5305 & 5257 & 4981 & 5124 & 4549 & 6341 & 5177 \\
\hline & 12 & 7760 & 6914 & 6729 & 6934 & 6817 & 6541 & 6733 & 6480 & 5952 & 6330 & 6262 \\
\hline & & 18 & 7777 & 7411 & 7335 & 7259 & 7295 & 7137 & 7293 & 7025 & 6658 & 6736 & 6600 \\
\hline & 24 & 8437 & 8159 & 8135 & 8004 & 8058 & 7718 & 7851 & 7901 & 7494 & 7505 & 7396 & 773 \\
\hline & & 30 & 8954 & 8527 & 8621 & 8167 & 8602 & 8241 & 8346 & 8194 & 7730 & 7930 & 7733 \\
\hline & 36 & 9064 & 8704 & 8783 & 8803 & 8847 & 8509 & 8712 & 8258 & 8138 & 7932 & 8138 \\
\hline & & 42 & 9720 & 9717 & 9429 & 9408 & 9294 & 9288 & 9282 & 9023 & 8730 & 8719 & 8559 \\
\hline
\end{tabular}


Table B-3. Hydroprobe Readings Observed During Test Three. (sheet 5 of 9)

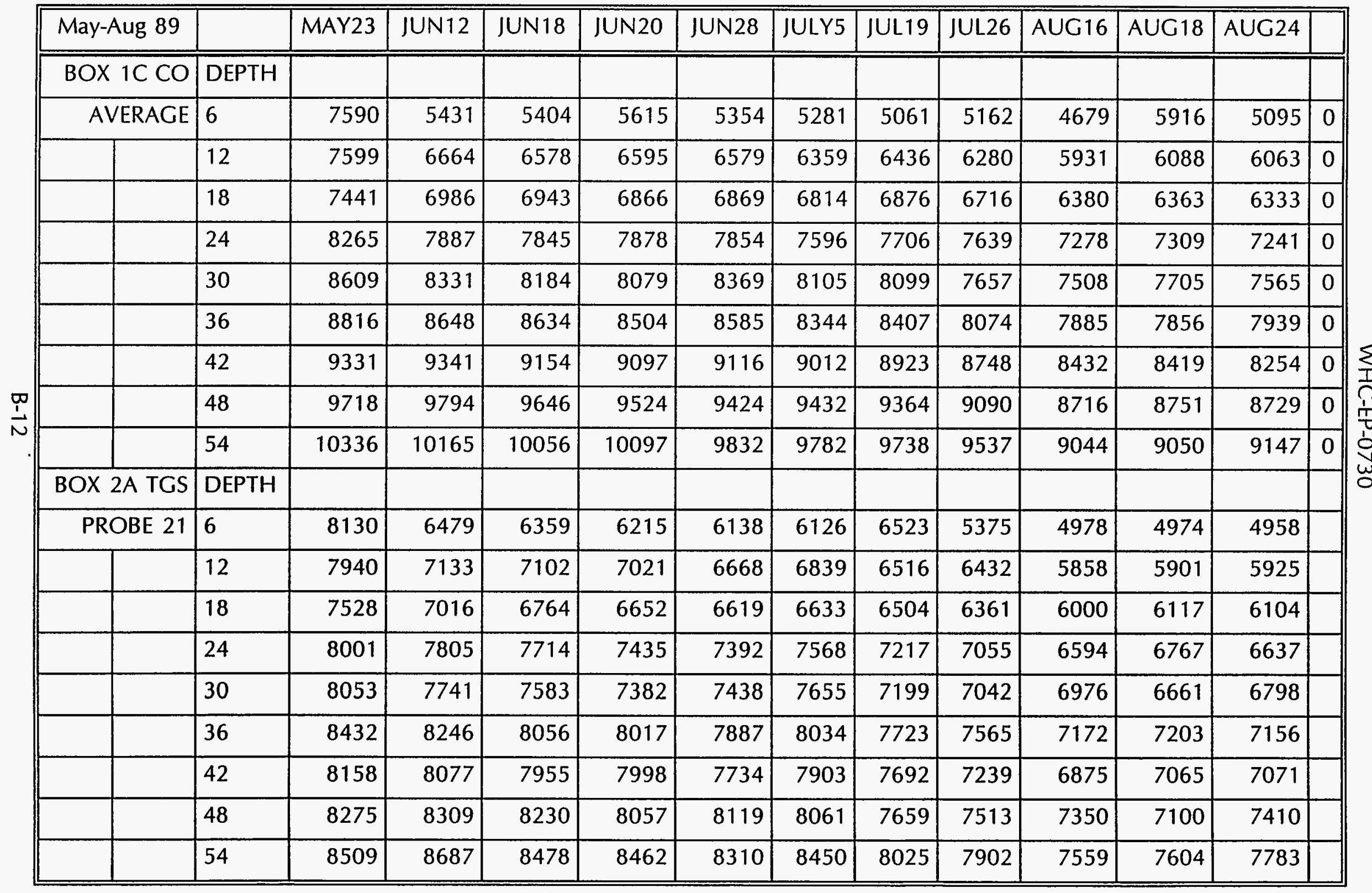


Table B-3. Hydroprobe Readings Observed During Test Three. (sheet 6 of 9)

\begin{tabular}{|c|c|c|c|c|c|c|c|c|c|c|c|c|c|}
\hline May-Aug 89 & & MAY23 & JUN12 & JUN18 & JUN20 & JUN28 & JULY5 & JUL19 & JUL26 & AUG16 & AUG18 & AUG24 & \\
\hline $\mathrm{BOX} 2 \mathrm{~A}$ TGS & DEPTH & & & & & & & & & & & & \\
\hline PROBE 22 & 6 & 7686 & 5677 & 5999 & 5487 & 5420 & 5069 & 5009 & 4786 & 4652 & 4537 & 4468 & \\
\hline & 12 & 7792 & 6962 & 6674 & 6665 & 6479 & 6391 & 6192 & 6069 & 5677 & 5811 & 5766 & \\
\hline & 18 & 7661 & 7005 & 6945 & 6965 & 6705 & 6796 & 6441 & 6372 & 6108 & 6045 & 6007 & \\
\hline & 24 & 8582 & 8121 & 7871 & 7726 & 7706 & 7650 & 7392 & 7365 & 6942 & 6972 & 6982 & \\
\hline & 30 & 7280 & 7277 & 6953 & 6850 & 6800 & 6866 & 6519 & 6530 & 6387 & 6191 & 6215 & \\
\hline & 36 & 8484 & 8200 & 8058 & 7927 & 7894 & 7896 & 7889 & 7766 & 7265 & 7331 & 7312 & \\
\hline & 42 & 8579 & 8487 & 8462 & 8467 & 8233 & 8229 & 8084 & 7891 & 7575 & 7573 & 7590 & \\
\hline & 48 & 8181 & 7957 & 7893 & 7793 & 7835 & 7760 & 7576 & 7285 & 7085 & 7003 & 7084 & \\
\hline & 54 & 8444 & 8583 & 8344 & 8055 & 8199 & 8233 & 8002 & 7806 & 7418 & 7286 & 7305 & \\
\hline BOX 2A TGS & DEPTH & & & & & & & & & & & & \\
\hline AVERAGE & 6 & 7908 & 6078 & 6179 & 5851 & 5779 & 5598 & 5766 & 5081 & 4815 & 4756 & 4713 & 0 \\
\hline & 12 & 7866 & 7048 & 6888 & 6843 & 6574 & 6615 & 6354 & 6251 & 5768 & 5856 & 5846 & 0 \\
\hline & 18 & 7595 & 7011 & 6855 & 6809 & 6662 & 6715 & 6473 & 6367 & 6054 & 6081 & 6056 & $\overline{0}$ \\
\hline & 24 & 8292 & 7963 & 7793 & 7581 & 7549 & 7609 & 7305 & 7210 & 6768 & 6870 & 6810 & 0 \\
\hline & 30 & 7667 & 7509 & 7268 & 7116 & 7119 & 7261 & 6859 & 6786 & 6682 & 6426 & 6507 & 0 \\
\hline & 36 & 8458 & 8223 & 8057 & 7972 & 7891 & 7965 & 7806 & 7666 & 7219 & 7267 & 7234 & $\overline{0}$ \\
\hline & 42 & 8369 & 8282 & 8209 & 8233 & 7984 & 8066 & 7888 & 7565 & 7225 & 7319 & 7331 & 0 \\
\hline & 48 & 8228 & 8133 & 8062 & 7925 & 7977 & 7911 & 7618 & 7399 & 7218 & 7052 & 7247 & 0 \\
\hline & 54 & 8477 & 8635 & 8411 & 8259 & 8255 & 8342 & 8014 & 7854 & 7489 & 7445 & 7544 & 0 \\
\hline
\end{tabular}


Table B-3. Hydroprobe Readings Observed During Test Three. (sheet 7 of 9)

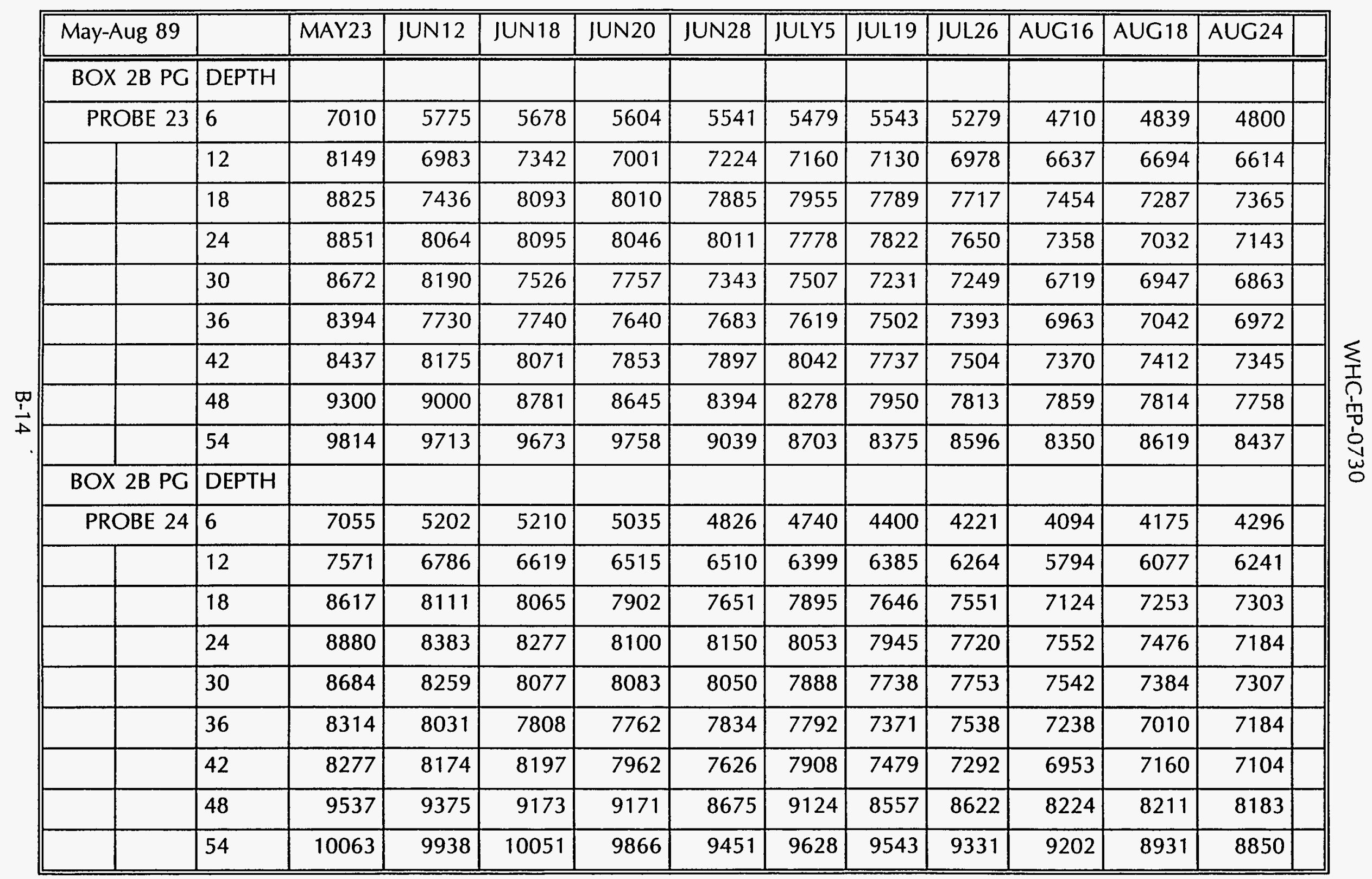


WHC-EP-0730

\begin{tabular}{|c|c|c|c|c|c|c|c|c|c|c|c|c|c|c|c|c|c|c|c|c|}
\hline & & 0 & 0 & 0 & 0 & 0 & 0 & 0 & 0 & 0 & & & & & & & & & & \\
\hline さ̇ & & \begin{tabular}{l}
$\infty$ \\
\multirow{f}{*}{} \\
$\stackrel{+}{+}$
\end{tabular} & 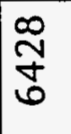 & $\stackrel{+}{m}$ & $\frac{t}{N}$ & $\begin{array}{l}10 \\
0 \\
0 \\
0\end{array}$ & $\begin{array}{l}\infty \\
i \\
0 \\
R\end{array}$ & $\stackrel{12}{\mathbb{N}}$ & 命 & $\underset{\infty}{5}$ & & $\begin{array}{l}\frac{8}{\sigma} \\
\frac{1}{8}\end{array}$ & 尽 & 옹 & $\underset{N}{N}$ & $\begin{array}{l}n \\
\infty \\
\infty\end{array}$ & $\begin{array}{l}m \\
\infty \\
\infty \\
\infty\end{array}$ & 尽 & 音 & $\begin{array}{l}0 \\
\text { 足 } \\
\infty\end{array}$ \\
\hline$\frac{\infty}{3}$ & & 官 & $\begin{array}{l}0 \\
\infty \\
m \\
0\end{array}$ & $\stackrel{0}{\stackrel{2}{N}}$ & 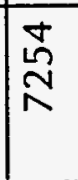 & $\frac{0}{n}$ & $\stackrel{0}{\stackrel{N}{O}}$ & $\begin{array}{l}0 \\
\infty \\
N\end{array}$ & $\frac{m}{\infty}$ & $\stackrel{1}{\infty}$ & & 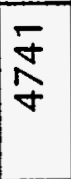 & 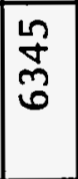 & $\begin{array}{l}\text { L } \\
\text { 10 } \\
0 \\
0\end{array}$ & $\begin{array}{l}m \\
0 \\
\tilde{n}\end{array}$ & $\hat{\tilde{O}}$ & $\frac{0}{n}$ & Nิ & $\begin{array}{l}\Omega \\
\\
0 \\
\infty\end{array}$ & $\begin{array}{l}n \\
\stackrel{N}{N} \\
\infty\end{array}$ \\
\hline$\frac{0}{3}$ & & O & $\frac{0}{\sqrt{0}}$ & $\begin{array}{l}\infty \\
\infty \\
\mathbb{N} \\
N\end{array}$ & in & $\frac{\bar{n}}{\bar{n}}$ & $\frac{5}{n}$ & $\frac{\tilde{O}}{\pi}$ & $\begin{array}{l}\mathcal{Y} \\
\stackrel{5}{\circ} \\
\infty\end{array}$ & $\begin{array}{l}0 \\
\\
\infty\end{array}$ & & $\begin{array}{l}\hat{y} \\
y \\
y\end{array}$ & $\begin{array}{l}\mathfrak{9} \\
\mathfrak{1} \\
\text { J }\end{array}$ & $\frac{\nabla}{N}$ & $\begin{array}{l}\bar{m} \\
n\end{array}$ & $\begin{array}{l}\infty \\
m \\
0 \\
\infty\end{array}$ & $\begin{array}{l}\nabla \\
\infty \\
\infty \\
\infty\end{array}$ & m & $\begin{array}{l}\infty \\
\infty \\
\infty \\
N\end{array}$ & $\underset{\infty}{\stackrel{ \pm}{N}}$ \\
\hline 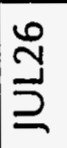 & & $\stackrel{0}{10}$ & $\overline{\tilde{v}}$ & 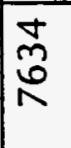 & $\begin{array}{l}n \\
\infty \\
0 \\
0\end{array}$ & $\begin{array}{l}5 \\
10 \\
\end{array}$ & 足 & $\begin{array}{l}\infty \\
\stackrel{\rho}{\circ} \\
\end{array}$ & $\underset{\infty}{\infty}$ & $\begin{array}{l}\text { J } \\
\text { ळ }\end{array}$ & & $\frac{\nabla}{\sigma}$ & $\frac{0}{6}$ & 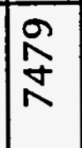 & 尔 & $\begin{array}{l}m \\
\text { N } \\
\text { in } \\
\infty\end{array}$ & $\underset{\sim}{\tilde{\infty}}$ & $\bar{\Sigma}$ & $\begin{array}{l}\infty \\
\infty \\
\infty \\
\infty\end{array}$ & $\bar{g}$ \\
\hline $\begin{array}{l}\frac{9}{5} \\
\Xi\end{array}$ & & 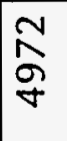 & 文 & $\frac{\infty}{N}$ & $\begin{array}{l}\forall \\
\Phi \\
\infty \\
N\end{array}$ & \begin{tabular}{l}
0 \\
$\infty$ \\
\multirow{N}{*}{}
\end{tabular} & 学 & $\begin{array}{l}\infty \\
0 \\
0 \\
\end{array}$ & $\underset{\infty}{+}$ & $\begin{array}{l}2 \\
12 \\
\infty \\
\infty\end{array}$ & & $\frac{8}{10}$ & సू & $\begin{array}{l}\Omega \\
\text { No } \\
\text { in }\end{array}$ & & 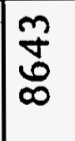 & $\underset{\infty}{\varpi}$ & $\begin{array}{l}\infty \\
\hat{0} \\
\infty\end{array}$ & $\begin{array}{l}\infty \\
0 \\
\infty \\
\infty\end{array}$ & \begin{tabular}{l}
\multirow{2}{\tilde{N}}{} \\
\multirow{\sigma}{\sigma}{}
\end{tabular} \\
\hline$\stackrel{\text { Ln }}{2}$ & & $\frac{0}{\frac{0}{6}}$ & $\begin{array}{l}0 \\
\infty \\
0 \\
0\end{array}$ & $\stackrel{10}{N}$ & $\frac{0}{\sigma}$ & $\begin{array}{l}\infty \\
0 \\
0 \\
1\end{array}$ & $\begin{array}{l}0 \\
\\
\end{array}$ & $\begin{array}{l}\text { L } \\
\hat{N} \\
\end{array}$ & $\underset{\infty}{\infty}$ & $\begin{array}{l}0 \\
0 \\
\sigma\end{array}$ & & \begin{tabular}{|} 
m \\
in \\
in
\end{tabular} & $\frac{N}{\infty}$ & $\frac{n}{\Re}$ & 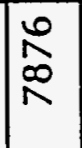 & $\underset{\infty}{\infty}$ & 齐 & $\begin{array}{l}\Omega \\
\\
\infty\end{array}$ & $\begin{array}{l}0 \\
10 \\
0 \\
\infty\end{array}$ & $\begin{array}{l}n \\
\text { బิ } \\
\sigma\end{array}$ \\
\hline 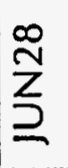 & & $\frac{5}{\infty}$ & $\begin{array}{l}0 \\
\infty \\
0\end{array}$ & $\stackrel{\infty}{N}$ & $\begin{array}{l}\infty \\
\infty \\
\infty\end{array}$ & م⿱ & 量 & No & $\begin{array}{l}n \\
n \\
10 \\
\infty \\
\infty\end{array}$ & $\begin{array}{l}\text { In } \\
\stackrel{\sim}{\sigma}\end{array}$ & & $\begin{array}{l}0 \\
1 \\
n \\
n \\
1\end{array}$ & $\mid \begin{array}{l}\Omega \\
\infty \\
0\end{array}$ & $\stackrel{n}{N}$ & $\underset{\substack{1 \\
\infty}}{\mathbb{\infty}}$ & $\begin{array}{l}\text { 용 } \\
\text { ᄋ }\end{array}$ & 舟 & 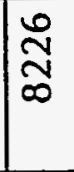 & 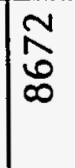 & $\begin{array}{l}\bar{z} \\
\sigma\end{array}$ \\
\hline 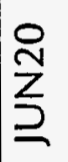 & & 오 & $\stackrel{\infty}{5}$ & $\begin{array}{l}0 \\
12 \\
0 \\
1\end{array}$ & $\stackrel{m}{\hat{0}}$ & O̊ & i & $\begin{array}{l} \\
\\
\\
\end{array}$ & $\begin{array}{l}\infty \\
8 \\
\infty \\
\infty\end{array}$ & $\frac{N}{\infty}$ & & $\begin{array}{l}9 \\
17 \\
15 \\
12\end{array}$ & $\begin{array}{l}10 \\
\infty \\
\infty \\
0 \\
0\end{array}$ & $\begin{array}{l}12 \\
\\
\end{array}$ & $\bar{\sigma}$ & $\mid \begin{array}{l}\infty \\
1 \\
\infty \\
\infty \\
\infty\end{array}$ & $\underset{\infty}{\stackrel{N}{N}}$ & $\begin{array}{l}\text { 尺 } \\
\text { N } \\
\infty\end{array}$ & $\mid \begin{array}{l}\infty \\
\tilde{b} \\
\infty\end{array}$ & $\begin{array}{l}\infty \\
\text { ஸू } \\
\sigma\end{array}$ \\
\hline$\frac{\infty}{z}$ & & 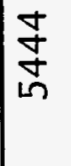 & $\bar{\infty}$ & 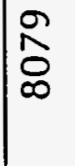 & $\frac{\infty}{\infty}$ & $\begin{array}{l}N \\
\delta \\
0 \\
N\end{array}$ & $\stackrel{\mathbb{R}}{\mathbb{N}}$ & $\frac{j}{\infty}$ & $\hat{N}$ & $\begin{array}{l}\text { } \\
\infty \\
\infty \\
\sigma\end{array}$ & & 怘 & $\mid \begin{array}{l}0 \\
\infty \\
0\end{array}$ & $\begin{array}{l}n \\
\infty \\
\infty\end{array}$ & $\frac{1}{\infty}$ & $\bar{\sigma}$ & 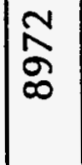 & $\begin{array}{l}n \\
\text { ñ } \\
\infty\end{array}$ & $\frac{\infty}{\infty}$ & $\begin{array}{l}\stackrel{n}{\sigma} \\
\Omega \\
\sigma\end{array}$ \\
\hline$\frac{\mathfrak{N}}{z}$ & & \begin{tabular}{l}
$\infty$ \\
$\infty$ \\
\multirow{+}{5}{} \\
n.
\end{tabular} & $\begin{array}{l}10 \\
\infty \\
\infty \\
0\end{array}$ & $\frac{\pi}{N}$ & $\begin{array}{l}\underset{N}{N} \\
\underset{\infty}{*}\end{array}$ & $\begin{array}{l}\stackrel{L}{N} \\
\underset{\infty}{\infty}\end{array}$ & $\begin{array}{l}\bar{\infty} \\
\infty \\
\infty\end{array}$ & $\frac{n}{\infty}$ & $\begin{array}{l}\infty \\
\infty \\
\sigma \\
\end{array}$ & $\begin{array}{l}0 \\
\text { N } \\
\text { o }\end{array}$ & & $\mid \begin{array}{c}9 \\
0 \\
0 \\
10\end{array}$ & مू & $\begin{array}{l}\text { I } \\
\text { I } \\
\infty\end{array}$ & $\frac{N}{\infty}$ & $\begin{array}{l}\dot{5} \\
\text { ᄋ }\end{array}$ & $\frac{1}{\infty}$ & $\begin{array}{l}8 \\
10 \\
\infty\end{array}$ & $\bar{\Xi}$ & $\begin{array}{l}0 \\
\tilde{J} \\
\sigma\end{array}$ \\
\hline$\frac{\infty}{\frac{n}{\delta}}$ & & $\stackrel{m}{m}$ & $\begin{array}{l}0 \\
\infty \\
\infty \\
N\end{array}$ & $\underset{\sim}{\pi}$ & $\begin{array}{l}0 \\
0 \\
\infty\end{array}$ & 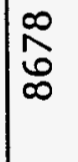 & $\begin{array}{l}\text { กิ } \\
\text { ભ }\end{array}$ & in & $\frac{\sigma}{\sigma}$ & 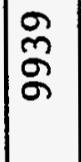 & & 恋 & $\begin{array}{l}\infty \\
\infty \\
\\
\end{array}$ & $\begin{array}{l}m \\
i \\
\infty \\
\infty\end{array}$ & $\begin{array}{l}\text { O } \\
\text { ஸै } \\
\varnothing \\
\infty\end{array}$ & 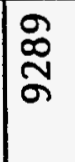 & 望 & $\begin{array}{l}\text { ชै } \\
\text { L } \\
\infty\end{array}$ & $\begin{array}{l}0 \\
0 \\
0 \\
\infty\end{array}$ & No \\
\hline & $\frac{I}{E}$ & 0 & $\simeq$ & $\infty$ & $\stackrel{ \pm}{ \pm}$ & 요 & m & $\mathscr{F}$ & $\mathscr{f}$ & 茫 & $\frac{I}{\frac{I}{U}}$ & 10 & $\stackrel{N}{=}$ & $\stackrel{\infty}{-}$ & $\stackrel{ \pm}{\sim}$ & in & m & F & $\stackrel{\infty}{+}$ & 品 \\
\hline $\begin{array}{l}0 \\
\infty \\
20 \\
3 \\
2\end{array}$ & $\frac{0}{n}$ & $\frac{\omega}{U}$ & & & & & & & & & $\begin{array}{l}O \\
U \\
U\end{array}$ & $\begin{array}{l}\stackrel{1}{2} \\
w \\
m \\
0\end{array}$ & & & & & & & & \\
\hline$\sum^{\grave{\delta}}$ & 10 & 18 & & & & & & & & & & & & & & & & & & \\
\hline
\end{tabular}


WHC-EP-0730

\begin{tabular}{|c|c|c|c|c|c|c|c|c|c|c|c|c|c|c|c|c|c|c|c|c|}
\hline & & & & & & & & & & & & 0 & 0 & 0 & 0 & 0 & 0 & 0 & 0 & 10 \\
\hline 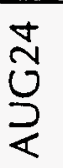 & & $\frac{0}{6}$ & $\begin{array}{l}n \\
\text { n } \\
0\end{array}$ & ฟֶ & $\begin{array}{l}\hat{m} \\
m\end{array}$ & $\begin{array}{l}\bar{\infty} \\
\infty \\
\infty\end{array}$ & $\frac{0}{\pi}$ & 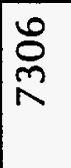 & $\frac{\bar{E}}{\infty}$ & $\begin{array}{l}\infty \\
\infty \\
\infty \\
\infty\end{array}$ & & $\underset{f}{\stackrel{\infty}{\rho}}$ & 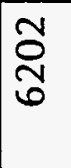 & $\begin{array}{c}\bar{N} \\
\infty \\
0\end{array}$ & $\begin{array}{c}\infty \\
m \\
n\end{array}$ & $\begin{array}{c}\infty \\
N \\
\infty \\
N\end{array}$ & $\begin{array}{l}0 \\
\text { 오 } \\
\end{array}$ & $\ddot{m}_{n}$ & $\begin{array}{l}\infty \\
\wp \\
\varnothing\end{array}$ & $\underset{\infty}{\stackrel{ \pm}{N}}$ \\
\hline$\frac{\infty}{2}$ & & $\bar{N}$ & $\hat{N}$ & 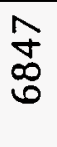 & $\begin{array}{l}\infty \\
N \\
N\end{array}$ & 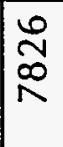 & $\begin{array}{l}\stackrel{ }{\text { V }} \\
\text { N }\end{array}$ & $\frac{\overline{ \pm}}{\pi}$ & $\underset{\infty}{\stackrel{\circ}{\mathscr{D}}}$ & 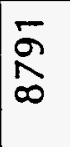 & & $\bar{m}$ & $\begin{array}{l}0 \\
0 \\
0 \\
0\end{array}$ & $\begin{array}{l}\overline{10} \\
\sigma \\
6\end{array}$ & $\frac{0}{n}$ & Ñ & $\begin{array}{l}\infty \\
\infty \\
\infty \\
1\end{array}$ & $\frac{N}{N}$ & $\frac{0}{\infty}$ & $\begin{array}{l}\widetilde{N} \\
\kappa\end{array}$ \\
\hline $\begin{array}{l}\frac{0}{3} \\
\frac{2}{\alpha}\end{array}$ & & 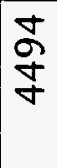 & $\stackrel{0}{R}$ & $\frac{\infty}{\infty}$ & $\frac{\hat{\sigma}}{\pi}$ & ஓু & $\underset{⿱}{\mathbb{N}}$ & No & $\frac{N}{\infty}$ & \begin{tabular}{l}
\multirow{\infty}{*}{} \\
$\infty$ \\
$\infty$
\end{tabular} & & $\frac{5}{5}$ & $\frac{12}{8}$ & $\frac{0}{0}$ & $\begin{array}{l}\text { Ju } \\
\text { N }\end{array}$ & $\frac{N}{\infty}$ & $\frac{9}{N}$ & 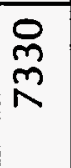 & $\begin{array}{l}0 \\
\text { p } \\
0\end{array}$ & $\begin{array}{l}0 \\
0 \\
\infty \\
\infty\end{array}$ \\
\hline$\stackrel{\stackrel{D}{\mathcal{J}}}{\supseteq}$ & & $\underset{m}{\tilde{m}}$ & $\begin{array}{l}\forall \\
\infty \\
\infty \\
\infty\end{array}$ & ํํํ & $\begin{array}{l}\infty \\
10 \\
10 \\
N\end{array}$ & $\begin{array}{l}\dot{m} \\
m \\
\infty\end{array}$ & $\frac{\sigma}{\sigma}$ & مै & $\begin{array}{l}0 \\
\infty \\
\infty \\
\infty \\
\infty\end{array}$ & $\begin{array}{l}\sigma \\
\infty \\
\tilde{\sigma}\end{array}$ & & $\stackrel{m}{\stackrel{m}{\gamma}}$ & ฮิ & $\begin{array}{l}0 \\
0 \\
N \\
N\end{array}$ & $\begin{array}{l}m \\
10 \\
0 \\
N\end{array}$ & 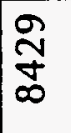 & $\frac{N}{\infty}$ & $\stackrel{8}{8}$ & $\begin{array}{l}\text { in } \\
1 \\
1 \\
\infty\end{array}$ & 导 \\
\hline$\stackrel{\sigma}{\Xi}$ & & \begin{tabular}{l}
$\mathfrak{N}$ \\
$\infty$ \\
$\infty$ \\
\multirow{+}{*}{}
\end{tabular} & $\begin{array}{l}\tilde{N} \\
\infty \\
\text { in }\end{array}$ & $\frac{\varrho}{1}$ & $\frac{\infty}{0}$ & \begin{tabular}{l}
+ \\
\multirow{2}{*}{} \\
$\infty$
\end{tabular} & $\begin{array}{l}\infty \\
\infty \\
\infty \\
\infty\end{array}$ & مי & $\underset{\infty}{\infty}$ & $\begin{array}{l}0 \\
\text { m }\end{array}$ & & 官 & in & $\stackrel{m}{\stackrel{m}{N}}$ & $\stackrel{0}{\stackrel{0}{人}}$ & $\begin{array}{l}8 \\
8 \\
0 \\
\infty\end{array}$ & $\frac{10}{\infty}$ & 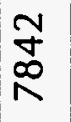 & $\begin{array}{l}\infty \\
0 \\
1 \\
\infty\end{array}$ & $\begin{array}{l}8 \\
\text { ñ }\end{array}$ \\
\hline$\stackrel{\text { in }}{ٍ}$ & & $\frac{N}{10}$ & $\frac{0}{\widetilde{v}}$ & 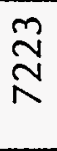 & $\begin{array}{l}\infty \\
\stackrel{\infty}{N}\end{array}$ & $\begin{array}{l}\infty \\
\infty \\
\infty\end{array}$ & $\frac{\hat{N}}{\infty}$ & م & $\begin{array}{l}\infty \\
\tilde{m} \\
\infty \\
\infty\end{array}$ & $\begin{array}{l}\tilde{v} \\
\text { ó } \\
\sigma\end{array}$ & & $\frac{\infty}{\infty}$ & $\frac{5}{50}$ & $\begin{array}{l}9 \\
8 \\
\end{array}$ & 尺̄ & $\begin{array}{l}\infty \\
0 \\
\infty \\
\infty\end{array}$ & $\begin{array}{c}\bar{\omega} \\
m \\
\infty\end{array}$ & $\frac{9}{\infty}$ & 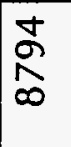 & $\begin{array}{l}m \\
\hat{\sigma} \\
\sigma\end{array}$ \\
\hline$\stackrel{\stackrel{\infty}{N}}{\stackrel{Z}{\supset}}$ & & $\frac{\infty}{m}$ & $\frac{0}{0}$ & $\stackrel{N}{\aleph}$ & 号 & $\underset{\infty}{\stackrel{N}{*}}$ & $\frac{0}{\infty}$ & $\begin{array}{l}\infty \\
\infty \\
0 \\
\infty\end{array}$ & $\frac{0}{\circ}$ & $\frac{\pi}{\operatorname{s}}$ & & ஸे & サ & $\frac{\pi}{2}$ & $\mid \begin{array}{l}0 \\
\infty \\
\infty \\
1 \\
1\end{array}$ & $\begin{array}{l}0 \\
\sim \\
\infty \\
\infty\end{array}$ & $\begin{array}{l}\infty \\
\infty \\
\infty \\
\infty\end{array}$ & $\frac{n}{\infty}$ & $\begin{array}{l} \pm \\
\infty \\
\infty \\
\infty\end{array}$ & 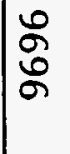 \\
\hline $\begin{array}{l}\stackrel{ }{Z} \\
\stackrel{Z}{ٍ}\end{array}$ & & $\begin{array}{l}\text { 足 } \\
\text { ஸn }\end{array}$ & $\bar{\sigma}$ & \begin{tabular}{l}
0 \\
\multirow{\sigma}{*}{}
\end{tabular} & $\frac{N}{N}$ & $\begin{array}{l}9 \\
1 \\
6 \\
\infty \\
\infty\end{array}$ & $\begin{array}{l}0 \\
\omega \\
\infty \\
\infty\end{array}$ & $\begin{array}{l}0 \\
\infty \\
\infty\end{array}$ & 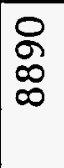 & 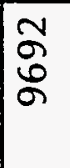 & & $\begin{array}{l}N \\
\infty \\
\text { in } \\
\text { ñ }\end{array}$ & $\begin{array}{l}\infty \\
m \\
0 \\
0\end{array}$ & $\frac{5}{12}$ & ڤ̊̊ & $\begin{array}{l}0 \\
10 \\
\infty \\
\infty\end{array}$ & $\begin{array}{l}0 \\
0 \\
\infty\end{array}$ & $\frac{m}{n}$ & 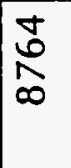 & ñ \\
\hline$\stackrel{\infty}{\underline{z}}$ & & $\frac{1}{\text { in }}$ & 告 & $\begin{array}{l}\stackrel{0}{L} \\
\stackrel{1}{N}\end{array}$ & $\frac{\infty}{\infty}$ & 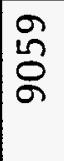 & 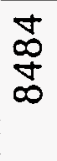 & $\underset{\sim}{\tilde{N}}$ & 市 & $\underline{\tilde{O}}$ & & m & 占 & ô & $\frac{N}{\infty}$ & $\begin{array}{l}8 \\
8 \\
8 \\
0\end{array}$ & $\underset{\infty}{\stackrel{\infty}{N}}$ & $\begin{array}{l}\infty \\
\infty \\
\infty \\
\infty\end{array}$ & $\begin{array}{l}0 \\
m \\
\infty\end{array}$ & $\frac{0}{\sigma}$ \\
\hline$\frac{N}{z}$ & & $\begin{array}{l}m \\
0 \\
0 \\
0\end{array}$ & $\underset{N}{\stackrel{O}{N}}$ & $\frac{\infty}{\infty}$ & $\frac{N}{8}$ & \begin{tabular}{l}
$\mathcal{O}$ \\
\multirow{+}{*}{}
\end{tabular} & $\overbrace{\infty}$ & $\begin{array}{l}\hat{m} \\
\tilde{\sigma}\end{array}$ & $\frac{\square}{8}$ & 兄. & & হু & in & Ŝ & $\begin{array}{l}10 \\
0 \\
0 \\
\infty\end{array}$ & $\frac{\infty}{\infty}$ & $\underset{\sim}{N}$ & $\underset{\infty}{\stackrel{m}{\infty}}$ & \begin{tabular}{l}
$\infty$ \\
\multirow{1}{\sigma}{} \\
$\sigma$
\end{tabular} & $\underline{m}$ \\
\hline$\frac{m}{i}$ & & $\underset{\sim}{\stackrel{N}{N}}$ & $\stackrel{Ð}{\stackrel{\overbrace{}}{N}}$ & $\underset{\infty}{\stackrel{m}{\sim}}$ & $\begin{array}{l}0 \\
10 \\
\infty\end{array}$ & \begin{tabular}{l}
0 \\
\multirow{\sigma}{\sigma}{} \\
$\sigma$
\end{tabular} & $\begin{array}{l}9 \\
0 \\
\infty \\
\infty\end{array}$ & $\begin{array}{l}1 \\
\infty \\
+\end{array}$ & $\frac{\sigma}{\sigma}$ & 용 & & $\frac{0}{n}$ & Oे & 舟 & $\begin{array}{l}m \\
0 \\
10 \\
\infty\end{array}$ & $\begin{array}{l}\infty \\
0 \\
\text { ma }\end{array}$ & 尚 & $\begin{array}{l}\tilde{1} \\
\text { in } \\
\infty\end{array}$ & $\frac{m}{a}$ & б \\
\hline & $\mid \begin{array}{c}I \\
\frac{F}{\Delta} \\
\text { 㟔 }\end{array}$ & 0 & $\stackrel{\sim}{\sim}$ & $\infty$ & $\stackrel{ \pm}{\sim}$ & 요 & ம) & $\stackrel{\mathscr{Y}}{\mathscr{V}}$ & $\stackrel{\infty}{\forall}$ & 芩 & $\frac{I}{\frac{I}{n}}$ & 0 & $\stackrel{2}{2}$ & $\stackrel{\infty}{\infty}$ & $\stackrel{ \pm}{\sim}$ & m & m & $\underset{f}{\mathscr{V}}$ & $\underset{+}{\infty}$ & 志 \\
\hline $\begin{array}{l}\infty \\
\infty \\
\infty 0 \\
2\end{array}$ & $\begin{array}{l}O \\
\cup \\
v\end{array}$ & $\begin{array}{l}0 \\
\sim \\
w \\
0 \\
0\end{array}$ & & & & & & & & & $\begin{array}{l}O \\
U \\
U\end{array}$ & 岁 & & & & & & & & \\
\hline$\stackrel{1}{\pi}^{\frac{1}{2}}$ & $\mid \begin{array}{l}x \\
0 \\
0\end{array}$ & $\frac{\alpha}{a}$ & & & & & & & & & 爻 & $1-$ & & & & & & & & \\
\hline
\end{tabular}


Table B-4. Hydroprobe Readings Observed During Test 4. (sheet 1 of 9)

\begin{tabular}{|c|c|c|c|c|c|c|c|c|c|c|c|c|c|}
\hline OCT 89-FEB 90 & & OCT3 & OC19 & OC25 & NOV2 & NO13 & $\mathrm{NO} 21$ & DEC4 & DE19 & JAN3 & JA12 & JA24 & JA31 \\
\hline BOX 1A PG & DEPTH & & & & & & & & & & & & \\
\hline PROBE 11 & 6 & 4221 & 3687 & 5275 & 5042 & 5050 & 7124 & 7066 & 6145 & 6741 & 7841 & 7150 & 5846 \\
\hline & 12 & 4651 & 4682 & 4904 & 4984 & 5080 & 5944 & 6280 & 6419 & 5867 & 6860 & 6868 & 5835 \\
\hline & 18 & 4817 & 4947 & 8966 & 4890 & 5072 & 4977 & 5359 & 5481 & 5480 & 5778 & 5921. & 5848 \\
\hline & 24 & 5921 & 5503 & 5966 & 5653 & 5449 & 5477 & 5633 & 5921 & 5671 & 5842 & 5950 & 5814 \\
\hline & 30 & 5610 & 5606 & 5537 & 5536 & 5690 & 5514 & 5519 & 5428 & 5696 & 5620 & 5569 & 5847 \\
\hline & 36 & 5927 & 5795 & 5723 & 5774 & 5745 & 5746 & 5649 & 5843 & 5887 & 5877 & $\overline{5972}$ & 6063 \\
\hline & 42 & 6219 & 5982 & 6003 & 6055 & 6106 & 6098 & 6042 & 5999 & 6104 & 6124 & 5969 & 5709 \\
\hline & 48 & 6212 & 6118 & 6194 & 6215 & 6164 & 6295 & 6255 & 6160 & 6184 & 5975 & 6053 & \\
\hline & 54 & 6516 & 6418 & & & & & & & & & & \\
\hline BOX 1A PG & DEPTH & & & & & & & & & & & & \\
\hline PROBE 12 & 6 & 4271 & 3635 & 5529 & 4950 & 5231 & 6223 & 6480 & 5791 & 6652 & 6979 & 6419 & 5880 \\
\hline & 12 & 5339 & 4741 & 4962 & 5027 & 5201 & 5718 & 5950 & 6086 & 6244 & 6781 & 6660 & 6423 \\
\hline & 18 & 5334 & 5095 & 5068 & 5020 & 5329 & 5312 & 5647 & 5887 & 6514 & 6307 & 6614 & 6557 \\
\hline & 24 & 4860 & 5004 & 5024 & 5012 & 5175 & 5057 & 5181 & 5227 & 5674 & 5547 & 5773 & 5766 \\
\hline & 30 & 5759 & 5730 & 5611 & 5722 & 5711 & 5691 & 5691 & 5707 & 5703 & 5970 & 5837 & 5830 \\
\hline & 36 & 6087 & 6088 & 5906 & 5866 & 5871 & 5934 & 5887 & 6083 & 5969 & 6012 & 5903 & 5932 \\
\hline & 42 & 6411 & 6035 & 5837 & 5824 & 5960 & 5801 & 5797 & 5963 & 5887 & 5940 & 5931 & 5862 \\
\hline & 48 & 6592 & 5909 & 6104 & 5982 & 6124 & 6089 & 6056 & 6054 & 6108 & 6024 & 5953 & 5832 \\
\hline & 54 & & 6189 & & & & & & & & & & \\
\hline
\end{tabular}


Table B-4. Hydroprobe Readings Observed During Test 4. (sheet 2 of 9)

\begin{tabular}{|c|c|c|c|c|c|c|c|c|c|c|c|c|c|}
\hline OCT 89-FEB 90 & & OCT3 & OC19 & OC25 & NOV2 & NO13 & NO21 & DEC4 & DE19 & JAN3 & JA12 & JA24 & JA31 \\
\hline BOX 1A PG & DEPTH & & & & & & & & & & & & \\
\hline \multirow[t]{9}{*}{ AVERAGE } & 6 & 4246 & 3661 & 5402 & 4996 & 5141 & 6674 & 6773 & 5968 & 6697 & 7410 & 6785 & 5863 \\
\hline & 12 & 4995 & 4712 & 4933 & 5006 & 5141 & 5831 & 6115 & 6253 & 6056 & 6821 & 6764 & 6129 \\
\hline & 18 & 5076 & 5021 & 7017 & 4955 & 5201 & 5145 & 5503 & 5684 & 5997 & 6043 & 6268 & 6203 \\
\hline & 24 & 5391 & 5254 & 5495 & 5333 & 5312 & 5267 & 5407 & 5574 & 5673 & 5695 & 5862 & 5790 \\
\hline & 30 & 5685 & 5668 & 5574 & 5629 & 5701 & 5603 & 5605 & 5568 & 5700 & 5795 & 5703 & 5839 \\
\hline & 36 & 6007 & 5942 & 5815 & 5820 & 5808 & 5840 & 5768 & 5963 & 5928 & 5945 & 5938 & 5998 \\
\hline & 42 & 6315 & 6009 & 5920 & 5940 & 6033 & 5950 & 5920 & 5981 & 5996 & 6032 & 5950 & 5786 \\
\hline & 48 & 6402 & 6014 & 6149 & 6099 & 6144 & 6192 & 6156 & 6107 & 6146 & 6000 & 6003 & 5771 \\
\hline & 54 & & 6304 & & & 0 & 0 & 0 & 0 & 0 & & & \\
\hline $\mathrm{BOX} 1 \mathrm{~B} \mathrm{PM}$ & DEPTH & & & & & & & & & & & & \\
\hline \multirow[t]{9}{*}{ PROBE 13 } & 6 & 4184 & 4067 & 5831 & 5800 & 5906 & 7813 & 7955 & 6747 & 7229 & 8541 & 7872 & 7415 \\
\hline & 12 & 5060 & 4967 & 5377 & 5549 & 5408 & 7680 & 7409 & 6672 & 6229 & 8146 & 7586 & 7378 \\
\hline & 18 & 5041 & 4944 & 5307 & 5104 & 5150 & 6082 & 6258 & 6215 & 5613 & 6325 & 6510 & 6363 \\
\hline & 24 & 5211 & 5324 & 5326 & 5483 & 5385 & 5531 & 5849 & 6120 & 6068 & 6085 & 6354 & 6408 \\
\hline & 30 & 5549 & 5622 & 5651 & 5694 & 5689 & 5698 & 5816 & 6156 & 6075 & 5856 & 6277 & 6329 \\
\hline & 36 & 5805 & 5741 & 5890 & 5961 & 5841 & 5801 & 5827 & 5920 & 5920 & 6110 & 6089 & 6099 \\
\hline & 42 & 6488 & 6295 & 6441 & 6331 & 6468 & 6342 & 6499 & 6347 & 6501 & 6668 & 6671 & 6678 \\
\hline & 48 & 6361 & 6381 & 6351 & 6372 & 6479 & 6518 & 6322 & 6371 & 6376 & 6433 & 6286 & 6363 \\
\hline & 54 & 6454 & 6354 & & & & & & & & & & \\
\hline
\end{tabular}


Table B-4. Hydroprobe Readings Observed During Test 4. (sheet 3 of 9)

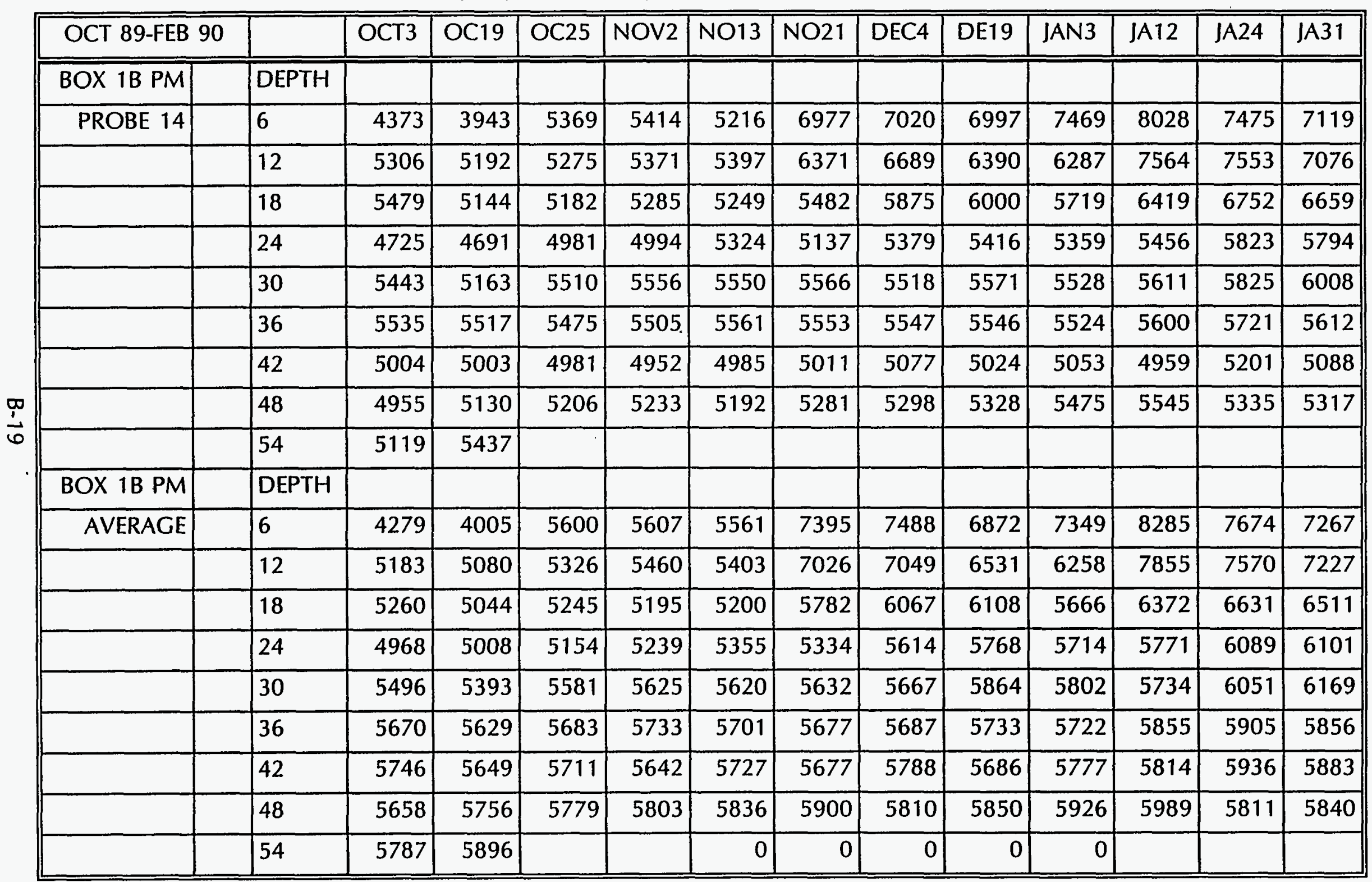


Table B-4. Hydroprobe Readings Observed During Test 4. (sheet 4 of 9)

\begin{tabular}{|c|c|c|c|c|c|c|c|c|c|c|c|c|c|}
\hline OCT 89-FEB 90 & & OCT3 & OC19 & OC25 & NOV2 & NO13 & NO21 & DEC4 & DE19 & JAN3 & JA12 & JA24 & JA31 \\
\hline $\mathrm{BOX} 1 \mathrm{C} \mathrm{CO}$ & DEPTH & & & & & & & & & & & & \\
\hline PROBE 15 & 6 & 4593 & 4750 & 6726 & 6213 & 6591 & 7877 & 7866 & 6786 & 7245 & 8529 & 7925 & 7432 \\
\hline & 12 & 5994 & 5906 & 6532 & 6583 & 6260 & 7601 & 7481 & 7014 & 6646 & 8135 & 7820 & 7755 \\
\hline & 18 & 6401 & 6479 & 6463 & 6609 & 6636 & 7137 & 7157 & 7099 & 6840 & 7539 & 7466 & 7681 \\
\hline & 24 & 6959 & 6873 & 7134 & 6917 & 7001 & 7152 & 7361 & 7466 & 7104 & 7411 & 7659 & 7698 \\
\hline & 30 & 7376 & 7268 & 7279 & 7340 & 7453 & 7429 & 7455 & 7781 & 7524 & 7618 & 7891 & 7697 \\
\hline & 36 & 7704 & 7537 & 7497 & 7652 & 7475 & 7391 & 7574 & 7601 & 7674 & 7674 & 7864 & 7887 \\
\hline & 42 & 8141 & 8052 & 8172 & 8135 & 8052 & 8112 & 7939 & 8029 & 8153 & 8013 & 8365 & 8242 \\
\hline & 48 & 8282 & 8133 & 8074 & 8180 & 7960 & 8208 & 8171 & 8219 & 8162 & 8197 & 8137 & 8315 \\
\hline & 54 & 8497 & 8392 & & & & & & & & & & \\
\hline $\mathrm{BOX} 1 \mathrm{C} \mathrm{CO}$ & DEPTH & & & & & & & & & & & & \\
\hline PROBE 16 & 6 & 4793 & 4827 & 5967 & 5929 & 6214 & 7446 & 7541 & 6987 & 7334 & 8299 & 7637 & 7292 \\
\hline & 12 & 5669 & 5552 & 6020 & 6083 & 5894 & 6855 & 7052 & 6471 & 6351 & 7515 & 7575 & 7218 \\
\hline & 18 & 5890 & 5900 & 6038 & 6127 & 5959 & 6197 & 6645 & 6582 & 6086 & 6899 & 6935 & 7095 \\
\hline & 24 & 6917 & 6755 & 6829 & 6728 & 6742 & 6796 & 7002 & 6908 & 6943 & 7155 & 7284 & 7389 \\
\hline & 30 & 7111 & 6960 & 7056 & 6794 & 6946 & 7100 & 7110 & 7132 & 7102 & 7151 & 7349 & 7358 \\
\hline & 36 & 7252 & 7216 & 7182 & 7282 & 7225 & 7137 & 7283 & 7304 & 7352 & 7453 & 7477 & 7524 \\
\hline & 42 & 7551 & 7689 & 7701 & 7602 & 7363 & 7539 & 7583 & 7677 & 7618 & 7566 & 7877 & 7811 \\
\hline & 48 & 8231 & 8140 & 8075 & 8032 & 8235 & 7930 & 8025 & 8080 & 8640 & 8262 & 8161 & 8353 \\
\hline & 54 & 8669 & 8616 & & & & & & & & & & \\
\hline
\end{tabular}




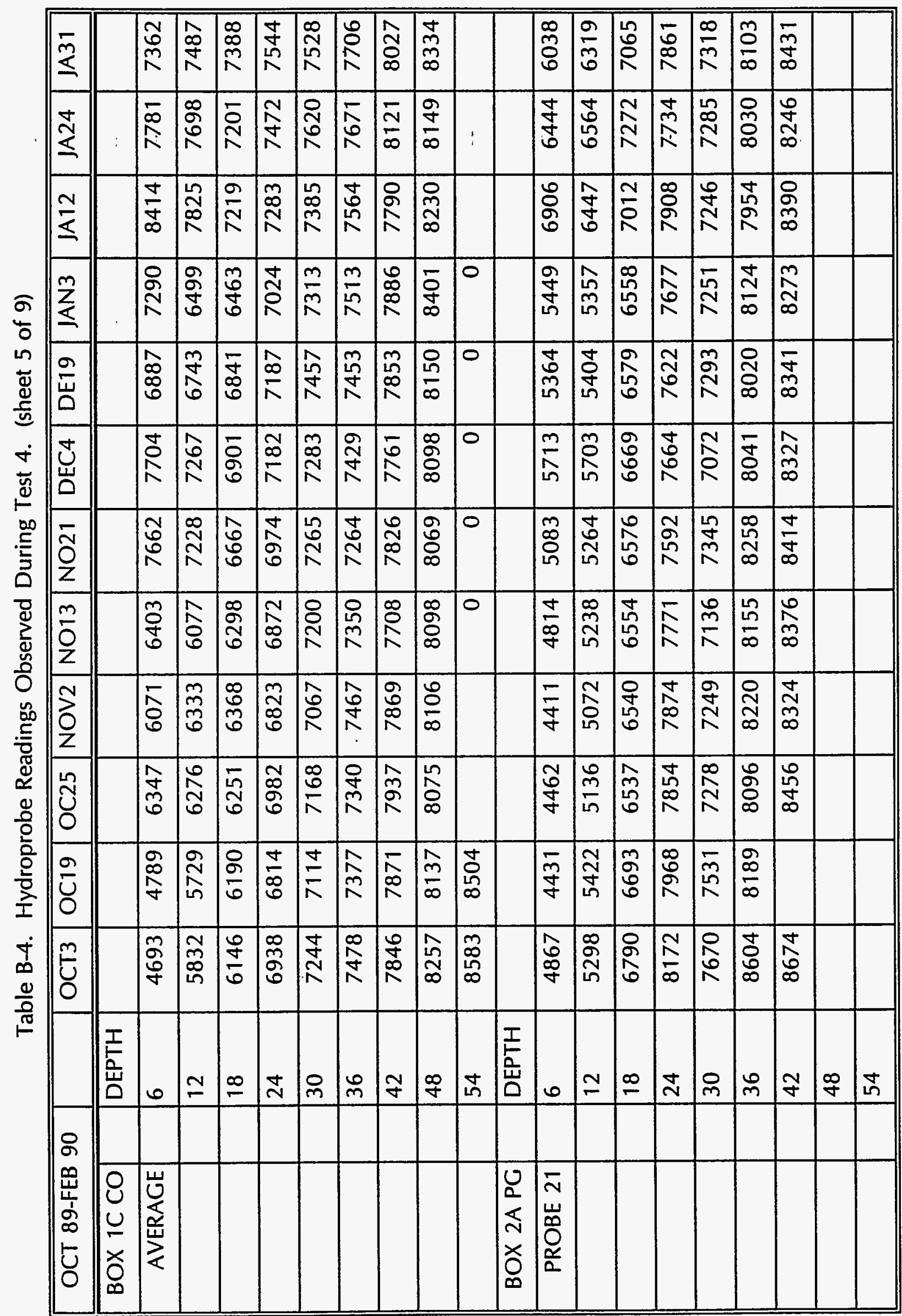




\begin{tabular}{|c|c|c|c|c|c|c|c|c|c|c|c|c|c|c|c|c|c|c|c|c|}
\hline$\underset{m}{m}$ & & $\stackrel{\text { m}}{\tilde{\delta}}$ & $\begin{array}{l}0 \\
0 \\
0 \\
0\end{array}$ & $\frac{0}{t}$ & $\overline{\check{\infty}}$ & 今్ & $\stackrel{8}{8}$ & $\begin{array}{l}n \\
\infty \\
0\end{array}$ & $\begin{array}{l}5 \\
\text { S } \\
10 \\
0\end{array}$ & & & $\overline{\tilde{m}}$ & $\frac{m}{n}$ & ○̊ & $\begin{array}{l}\bar{\sigma} \\
\delta\end{array}$ & $\begin{array}{l}\infty \\
0 \\
0\end{array}$ & $\frac{N}{N}$ & 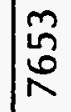 & $\begin{array}{l}8 \\
\text { m } \\
m\end{array}$ & \\
\hline$\underset{⿱ 亠 乂}{\mathbb{2}}$ & & $\begin{array}{l}n \\
\infty \\
\tilde{n}\end{array}$ & $\begin{array}{l}\overline{0} \\
\tilde{6}\end{array}$ & $\frac{m}{\tilde{T}}$ & ఫ্ঠ & ふ্ & $\stackrel{\sim}{\sim}$ & 京 & 点 & & & $\frac{1}{8}$ & $\begin{array}{l}n \\
0 \\
10 \\
0\end{array}$ & 足 & $\mid \begin{array}{l}\infty \\
\infty \\
\infty \\
\infty \\
1\end{array}$ & $\frac{0}{1}$ & $\mid \begin{array}{l}\infty \\
\infty \\
0\end{array}$ & 命 & $\hat{m}$ & \\
\hline$\frac{N}{\leq}$ & & $\begin{array}{l}m \\
8 \\
0 \\
0\end{array}$ & O̊ & $\frac{\nabla}{\operatorname{Ln}}$ & $\stackrel{m}{N}$ & 离 & $\stackrel{\infty}{\stackrel{\infty}{n}} \underset{N}{N}$ & $\begin{array}{l}8 \\
\frac{8}{2} \\
6\end{array}$ & $\begin{array}{l}1 \\
0 \\
0 \\
0\end{array}$ & & & $\begin{array}{l}12 \\
12 \\
0 \\
0\end{array}$ & $\underset{\stackrel{10}{y}}{\stackrel{y}{\sigma}}$ & mo & $\underset{N}{N}$ & $\begin{array}{l}8 \\
\text { 읏 } \\
\end{array}$ & 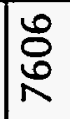 & $\begin{array}{l}\Omega \\
\text { in } \\
\text { In }\end{array}$ & $\begin{array}{l}\dot{J} \\
\dot{m} \\
m\end{array}$ & \\
\hline$\underset{z}{z}$ & & $\begin{array}{l}\stackrel{g}{ \pm} \\
\underset{\sigma}{ }\end{array}$ & $\underset{\text { in }}{\stackrel{m}{+}}$ & $\begin{array}{l}\tilde{m} \\
\tilde{\omega} \\
\sigma\end{array}$ & $\begin{array}{l}\stackrel{\infty}{\sim} \\
\stackrel{\infty}{N}\end{array}$ & $\begin{array}{l}\tilde{n} \\
\infty \\
\infty\end{array}$ & $\frac{m}{n}$ & $\begin{array}{l}9 \\
+ \\
6 \\
\end{array}$ & $\begin{array}{l}10 \\
6 \\
12 \\
6\end{array}$ & & & $\begin{array}{l}0 \\
0 \\
\infty \\
10\end{array}$ & $\begin{array}{l}\text { 은 } \\
10 \\
\text { in }\end{array}$ & ○ீ & $\stackrel{n}{i}$ & $\stackrel{\underset{y}{N}}{\stackrel{N}{N}}$ & $\begin{array}{l}0 \\
\text { in } \\
0 \\
1\end{array}$ & $\frac{n}{n}$ & $\begin{array}{l}m \\
\infty \\
\sim \\
m\end{array}$ & 0 \\
\hline$\frac{\sigma}{\frac{\sigma}{0}}$ & & $\begin{array}{l}n \\
\text { in } \\
\text { in }\end{array}$ & $\begin{array}{l}0 \\
0 \\
0 \\
10 \\
10\end{array}$ & ๙ั & $\begin{array}{l}\text { 용 } \\
0 \\
0 \\
1\end{array}$ & $\frac{0}{\infty}$ & $\begin{array}{l}\infty \\
\infty \\
\mathbb{N}\end{array}$ & $\begin{array}{l}10 \\
10 \\
0\end{array}$ & 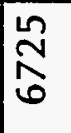 & & & $\frac{\bar{m}}{\mathrm{~m}}$ & $\begin{array}{l}12 \\
n \\
1 \\
1 \\
\text { nd }\end{array}$ & $\begin{array}{l}1 \\
\infty \\
10 \\
0\end{array}$ & $\frac{\nabla}{\lambda}$ & 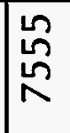 & $\begin{array}{l}n \\
\text { in } \\
0\end{array}$ & 文 & $\begin{array}{l}m \\
\tilde{m} \\
m\end{array}$ & 0 \\
\hline 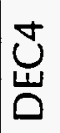 & & $\begin{array}{l}\text { in } \\
\text { In } \\
\text { Ln }\end{array}$ & $\begin{array}{l}\overline{1} \\
\text { in } \\
\text { in }\end{array}$ & $\frac{6}{6}$ & $\frac{n}{\infty}$ & 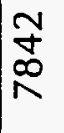 & $\frac{m}{n}$ & $\begin{array}{l}0 \\
0 \\
0 \\
0\end{array}$ & 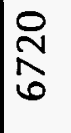 & & & $\begin{array}{l}10 \\
\infty \\
10 \\
12\end{array}$ & $\begin{array}{l}\hat{y} \\
\tilde{o} \\
\text { เ }\end{array}$ & m & $\begin{array}{l}\stackrel{P}{\mathbb{2}} \\
\text { 尺े }\end{array}$ & in & 용 & $\begin{array}{l}\text { 昌 } \\
\text { 㖞 } \\
\end{array}$ & $\begin{array}{l}0 \\
\text { m } \\
\text { m }\end{array}$ & 10 \\
\hline 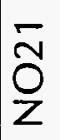 & & $\begin{array}{l}10 \\
\infty \\
10 \\
+\end{array}$ & 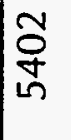 & $\underset{f}{\tilde{t}}$ & 용 & 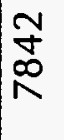 & $\frac{N}{n}$ & $\begin{array}{l}\tilde{f} \\
0 \\
0\end{array}$ & \begin{tabular}{l}
$\infty$ \\
\multirow{N}{*}{} \\
0 \\
0
\end{tabular} & & & $\begin{array}{l}+ \\
\infty \\
\infty \\
+\end{array}$ & $\begin{array}{l}m \\
m \\
m \\
n\end{array}$ & \begin{tabular}{l} 
\pm \\
\multirow{2}{*}{} \\
$\sigma$
\end{tabular} & $\frac{\sigma}{\mathbb{2}}$ & \begin{tabular}{l}
\multirow{2}{*}{} \\
In \\
\end{tabular} & $\begin{array}{l}\infty \\
\infty \\
N\end{array}$ & $\begin{array}{l}n \\
\text { in } \\
N\end{array}$ & $\frac{\dot{v}}{m}$ & 0 \\
\hline$\frac{m}{\varrho}$ & & 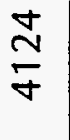 & 吉 & $\frac{\sigma}{6}$ & $\underset{\substack{\infty\\
}}{\bar{\infty}}$ & $\frac{N}{\infty}$ & 농 & 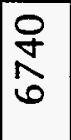 & $\begin{array}{l}m \\
\hat{\sigma}\end{array}$ & & & $\begin{array}{l}9 \\
0 \\
\\
+\end{array}$ & $\begin{array}{l}\bar{b} \\
\tilde{n} \\
\text { in }\end{array}$ & $\begin{array}{l}m \\
\infty \\
1 \\
0\end{array}$ & $\begin{array}{l}\overline{0} \\
\infty \\
1\end{array}$ & 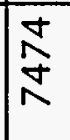 & $\stackrel{P}{R}$ & $\begin{array}{l}\infty \\
10 \\
10 \\
1\end{array}$ & $\begin{array}{l}\tilde{J} \\
m\end{array}$ & 0 \\
\hline$\stackrel{\Upsilon}{Z}$ & & $\begin{array}{l}\infty \\
\infty \\
m \\
m\end{array}$ & $\begin{array}{l}\mathcal{N} \\
\tilde{n} \\
\tilde{n}\end{array}$ & $\begin{array}{l}\text { 응 } \\
\text { ำ }\end{array}$ & 今̊ & $\begin{array}{l}\mathscr{2} \\
\stackrel{\infty}{1} \\
1\end{array}$ & $\underset{\sim}{\stackrel{\infty}{N}}$ & 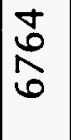 & $\begin{array}{l}\mathcal{N} \\
\infty \\
\infty \\
0\end{array}$ & & & $\begin{array}{l}\text { g } \\
\text { ले }\end{array}$ & $\frac{N}{\tilde{N}}$ & $\begin{array}{l} \pm \\
\text { ป } \\
\text { हु }\end{array}$ & $\begin{array}{l}\sigma \\
\infty \\
\infty\end{array}$ & $\stackrel{m}{N}$ & $\begin{array}{l}\Omega \\
\text { in } \\
N\end{array}$ & 离 & & \\
\hline$\stackrel{\sim}{U}$ & & $\frac{0}{2}$ & $\frac{\hat{\sigma}}{i n}$ & $\begin{array}{l}\text { W } \\
\text { ఫ̛ } \\
0\end{array}$ & 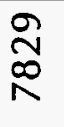 & $\begin{array}{l}\sim \\
\infty \\
\infty \\
\infty\end{array}$ & $\bar{\kappa}$ & $\begin{array}{l}\bar{\sigma} \\
\hat{\sigma}\end{array}$ & 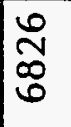 & & & $\frac{0}{8}$ & กิ & $\mid \begin{array}{l}0 \\
6 \\
6 \\
6\end{array}$ & $\underset{\mathcal{J}}{\stackrel{\mathcal{D}}{\mathcal{N}}}$ & $\begin{array}{l}0 \\
\infty \\
1 \\
N\end{array}$ & 竎 & $\underset{\sim}{\sim}$ & $\frac{m}{\dot{m}}$ & \\
\hline$\frac{a}{\tilde{U}}$ & & $\begin{array}{l}0 \\
\infty \\
0 \\
\text { లి }\end{array}$ & 竎 & 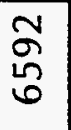 & 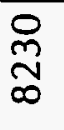 & 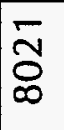 & 守 & $\begin{array}{l}0 \\
\infty \\
\hat{N} \\
0\end{array}$ & $\begin{array}{l}5 \\
10 \\
6\end{array}$ & 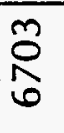 & & $\begin{array}{l}0 \\
\\
\end{array}$ & $\begin{array}{l}\text { m } \\
\text { in } \\
\text { in }\end{array}$ & m & \% & $\stackrel{N}{N}$ & $\frac{n}{\infty}$ & $\begin{array}{l}m \\
\tilde{m} \\
m\end{array}$ & $\frac{0}{N}$ & $\begin{array}{l}\tilde{N} \\
\tilde{m} \\
m\end{array}$ \\
\hline$\stackrel{m}{\underline{U}}$ & & $\frac{\sigma}{N}$ & $\frac{0}{6}$ & \begin{tabular}{l}
0 \\
Ln \\
\multirow{2}{*}{}
\end{tabular} & $\frac{\infty}{\infty}$ & 今ે & $\stackrel{m}{\stackrel{m}{n}}$ & $\frac{1 n}{\infty}$ & 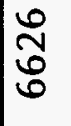 & 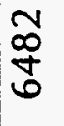 & & $\begin{array}{l}m \\
\tilde{w} \\
\tilde{v}\end{array}$ & N & 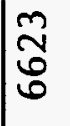 & $\frac{10}{\infty}$ & $\begin{array}{l}\Omega \\
\text { m } \\
\wp\end{array}$ & 同 & $\frac{n}{N}$ & & \\
\hline & $\frac{I}{5}$ & 0 & $\because$ & $\infty$ & $\sim$ & $\bar{m}$ & $m$ & $\mathscr{V}$ & $\underset{+}{\infty}$ & in & $\frac{I}{5}$ & 0 & $1-$ & $1-$ & $\stackrel{ \pm}{\sim}$ & m & $m$ & $\mathcal{F}$ & $\stackrel{\infty}{+}$ & เก \\
\hline
\end{tabular}

8

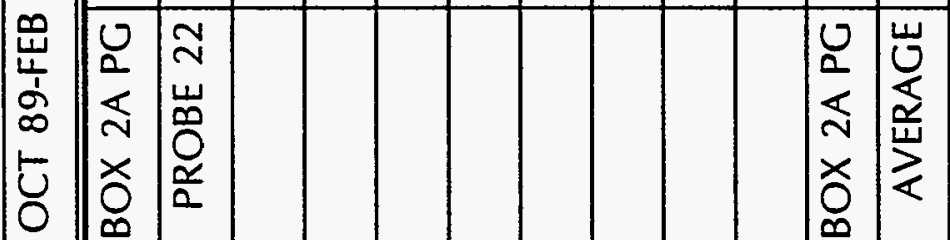


Table B-4. Hydroprobe Readings Observed During Test 4. (sheet 7 of 9)

\begin{tabular}{|c|c|c|c|c|c|c|c|c|c|c|c|c|c|}
\hline OCT 89-FEB & & OCT3 & OC19 & OC25 & NOV2 & NO13 & $\mathrm{NO} 21$ & DEC4 & DE19 & JAN3 & JA12 & JA24 & JA31 \\
\hline $\mathrm{BOX} 2 \mathrm{~B} \mathrm{PM}$ & DEPTH & & & & & & & & & & & & \\
\hline \multirow[t]{9}{*}{ PROBE 23} & 6 & 4616 & 4214 & 4615 & 4740 & 5402 & 6153 & 6925 & 6446 & 6746 & 8298 & 7463 & 7420 \\
\hline & 12 & 5404 & 5455 & 5434 & 5549 & 5483 & 5852 & 6465 & 6450 & 6052 & 7836 & 7561 & 7538 \\
\hline & 18 & 5430 & 5597 & 5694 & 5656 & 5643 & 5589 & 5988 & 6065 & 5836 & 6678 & 7050 & 6974 \\
\hline & 24 & 5431 & 5726 & 5646 & 5630 & 5674 & 5632 & 5672 & 5786 & 5839 & $\overline{6046}$ & 6310 & 6282 \\
\hline & 30 & 6163 & 6032 & 6178 & 6122 & 6172 & 6068 & 6079 & 5999 & 5991 & 6092 & 6335 & 6171 \\
\hline & 36 & 7046 & 7021 & 6987 & 6904 & 6841 & 6887 & 6914 & 6799 & 6760 & 6762 & 6929 & 6931 \\
\hline & 42 & 7749 & 7721 & 7579 & 7424 & 7500 & 7269 & 7534 & 7457 & 7521 & 7515 & 7562 & 7453 \\
\hline & 48 & 7394 & 7157 & 7105 & 7046 & 7105 & 7024 & 6999 & 6954 & 7094 & 7022 & 7018 & 7071 \\
\hline & 54 & 7422 & 7331 & & & & & & & & & & \\
\hline $\mathrm{BOX} 2 \mathrm{~B} \mathrm{PM}$ & DEPTH & & & & & & & & & & & & \\
\hline \multirow[t]{9}{*}{ PROBE 24} & 6 & 5136 & 4751 & 4730 & 4663 & 5190 & 5554 & 6033 & 6081 & 6410 & 7638 & 6813 & 6399 \\
\hline & 12 & 4968 & 5053 & 5074 & 5118 & 4995 & 5086 & 5642 & 5637 & 5534 & 6440 & 6744 & 6573 \\
\hline & 18 & 5264 & 5278 & 5428 & 5296 & 5380 & 5465 & 5530 & 5763 & $\overline{5643}$ & 5903 & 6477 & 6428 \\
\hline & 24 & 5412 & 5403 & 5413 & 5490 & 5521 & 5491 & 5442 & 5598 & 5479 & 5638 & 5823 & 5867 \\
\hline & 30 & 5990 & 5800 & 5921 & 5867 & 5889 & 5879 & 5925 & 5870 & 5873 & 6049 & 5998 & 6124 \\
\hline & 36 & 6516 & 6478 & 6491 & 6348 & 6323 & 6384 & 6280 & 6401 & 6355 & 6462 & 6619 & 6427 \\
\hline & 42 & 6679 & 6626 & 6614 & 6607 & 6491 & 6416 & 6519 & 6359 & 6482 & 6542 & 6579 & 6651 \\
\hline & 48 & & & & & & & & & & & & \\
\hline & 54 & & & & & & & & & & & & \\
\hline
\end{tabular}


Table B-4. Hydroprobe Readings Observed During Test 4. (sheet 8 of 9)

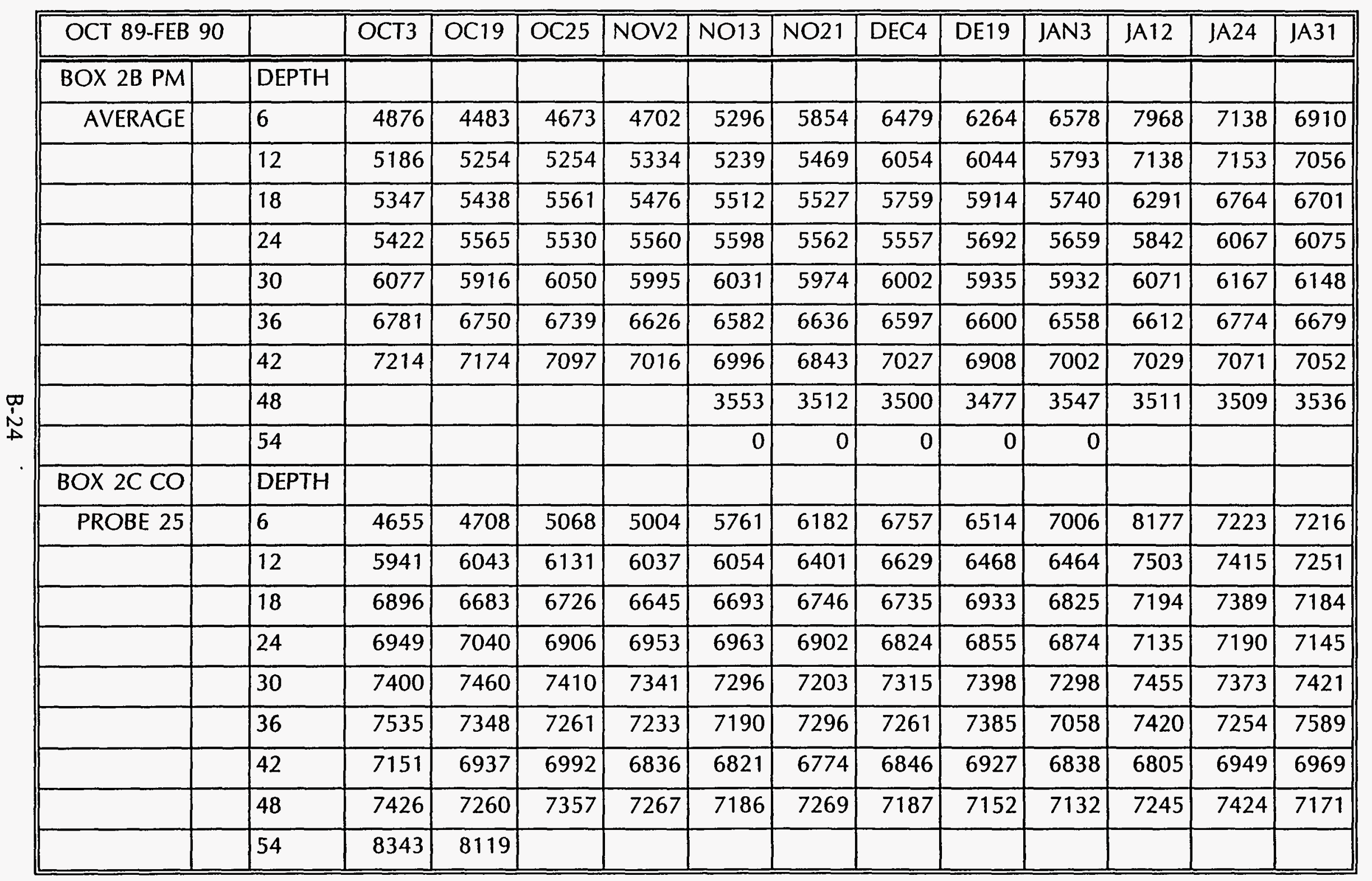


Table B-4. Hydroprobe Readings Observed During Test 4. (sheet 9 of 9)

\begin{tabular}{|c|c|c|c|c|c|c|c|c|c|c|c|c|c|}
\hline OCT 89-FEB 90 & & OCT3 & OC19 & OC25 & NOV2 & NO13 & $\mathrm{NO} 21$ & DEC4 & DE19 & JAN3 & JA12 & JA24 & JA31 \\
\hline & 12 & 5618 & 5521 & 6131 & 5636 & 5761 & 5867 & 6094 & 5949 & 5975 & 6605 & 6564 & 6397 \\
\hline & 18 & 6541 & 6380 & 6726 & 6407 & 6353 & 6384 & 6607 & 6450 & 6482 & 6931 & 7036 & 6870 \\
\hline & 24 & 6976 & 6847 & 6906 & 6912 & 6764 & 6876 & \begin{tabular}{ll|}
6843 \\
\end{tabular} & 6845 & 6859 & 6771 & 7130 & 6984 \\
\hline & 30 & 7387 & 7386 & 7410 & 7403 & 7357 & 7466 & 7352 & 7275 & 7442 & 7468 & 7349 & 7421 \\
\hline & 36 & 7289 & 6973 & 7261 & 6969 & 7064 & 6905 & 6851 & 6846 & 7016 & 7042 & 6974 & 7022 \\
\hline & 42 & 6867 & 6883 & 6992 & 6601 & 6547 & 6786 & 6694 & 6797 & 6736 & 6717 & 6811 & 7004 \\
\hline & $\longdiv { 4 8 }$ & 7845 & 7720 & 7357 & 7630 & 7533 & 7506 & 7401 & 7414 & 7378 & 7466 & 7588 & 7512 \\
\hline & 54 & 8353 & 8229 & & & & & & & & & & \\
\hline $\mathrm{BOX} 2 \mathrm{CCO}$ & DEPTH & & & & & & & & & & & & \\
\hline AVERAGE & 6 & 4613 & 4672 & 5068 & 4978 & 5578 & 6045 & 6550 & 6245 & 6780 & 7732 & 6974 & 6861 \\
\hline & 12 & 5780 & 5782 & 6131 & 5837 & 5908 & 6134 & 6362 & 6209 & 6220 & 7054 & 6990 & 6824 \\
\hline & 18 & 6719 & 6532 & 6726 & 6526 & 6523 & 6565 & 6671 & 6692 & 6654 & 7063 & 7213 & 7027 \\
\hline & 24 & 6963 & 6944 & 6906 & 6933 & 6864 & 6889 & 6834 & 6850 & 6867 & 6953 & 7160 & 7065 \\
\hline & 30 & 7394 & 7423 & 7410 & 7372 & 7327 & 7335 & 7334 & 7337 & 7370 & 7462 & 7361 & 7421 \\
\hline & 36 & 7412 & 7161 & 7261 & 7101 & 7127 & 7101 & 7056 & 7116 & 7037 & 7231 & 7114 & 7306 \\
\hline & 42 & 7009 & 6910 & 6992 & 6719 & 6684 & 6780 & 6770 & 6862 & 6787 & 6761 & 6880 & 6987 \\
\hline & 48 & 7636 & 7490 & 7357 & 7449 & 7360 & 7388 & 7294 & 7283 & 7255 & 7356 & 7506 & 7342 \\
\hline & 54 & 8348 & 8174 & & & 0 & $\overline{0}$ & 0 & 0 & 0 & & & \\
\hline
\end{tabular}


Table B-5. Hydroprobe Readings Observed During Test 5. (sheet 1 of 9)

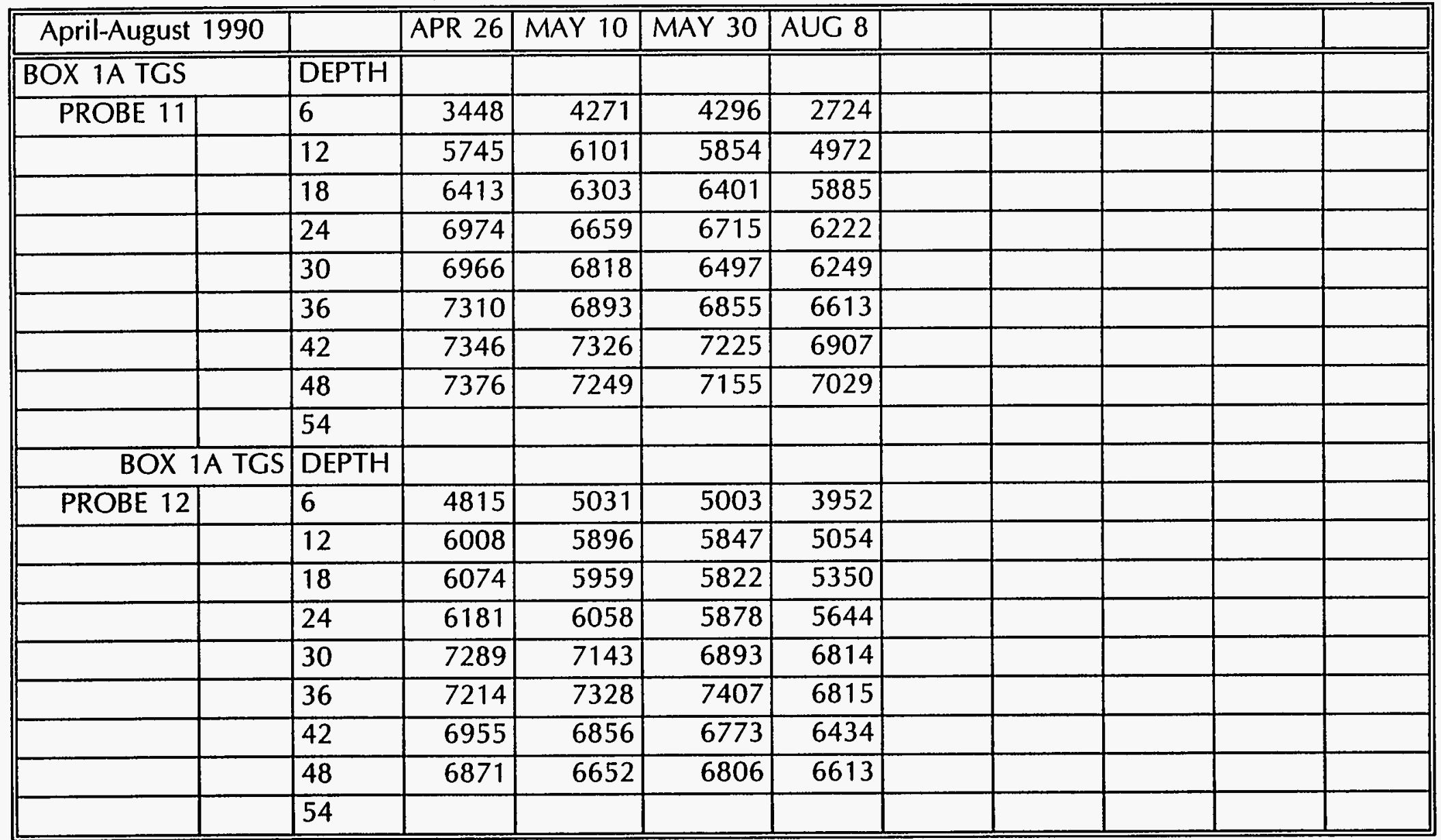


Table B-5. Hydroprobe Readings Observed During Test 5. (sheet 2 of 9)

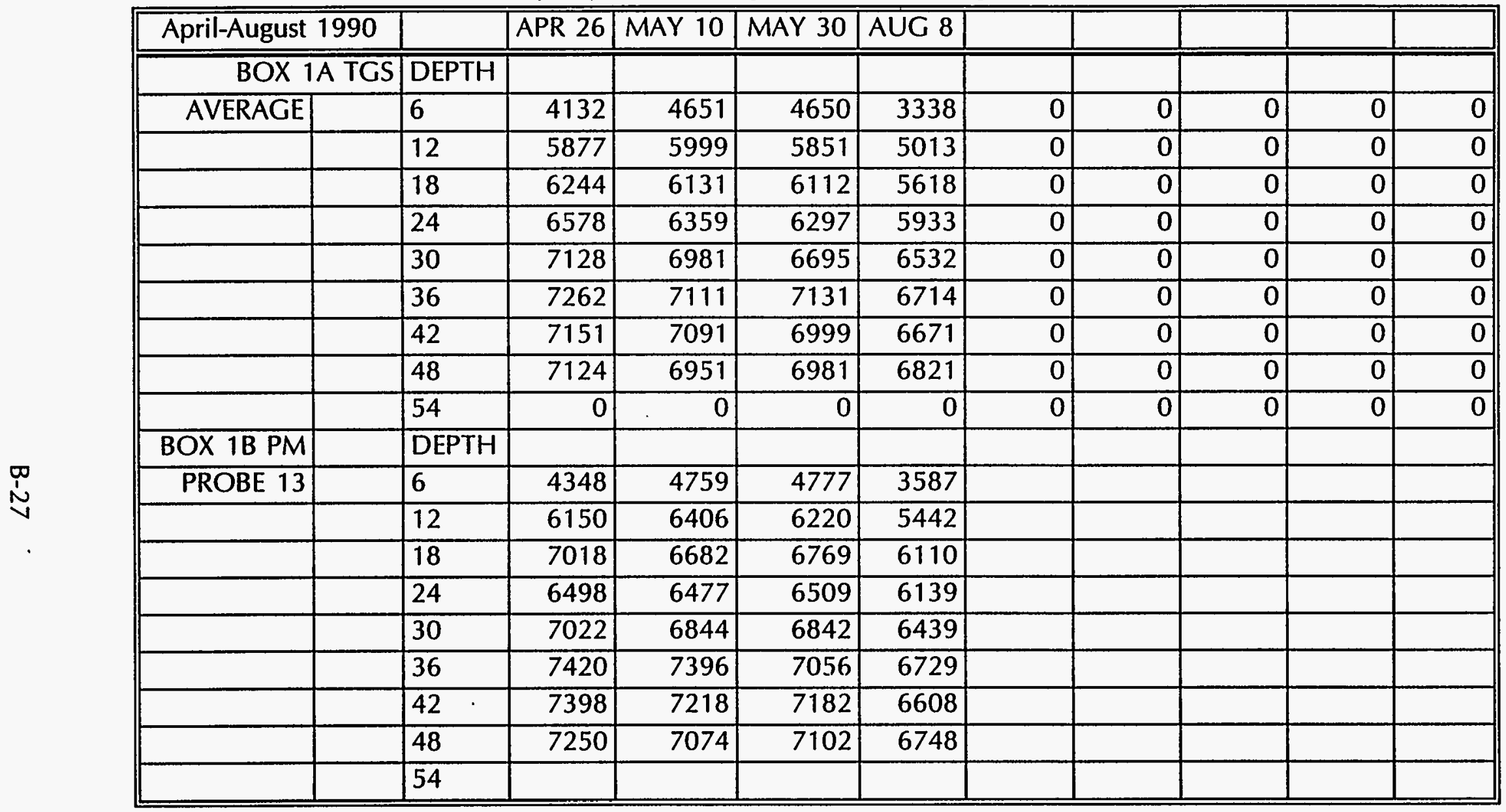


Table B-5. Hydroprobe Readings Observed During Test 5. (sheet 3 of 9)

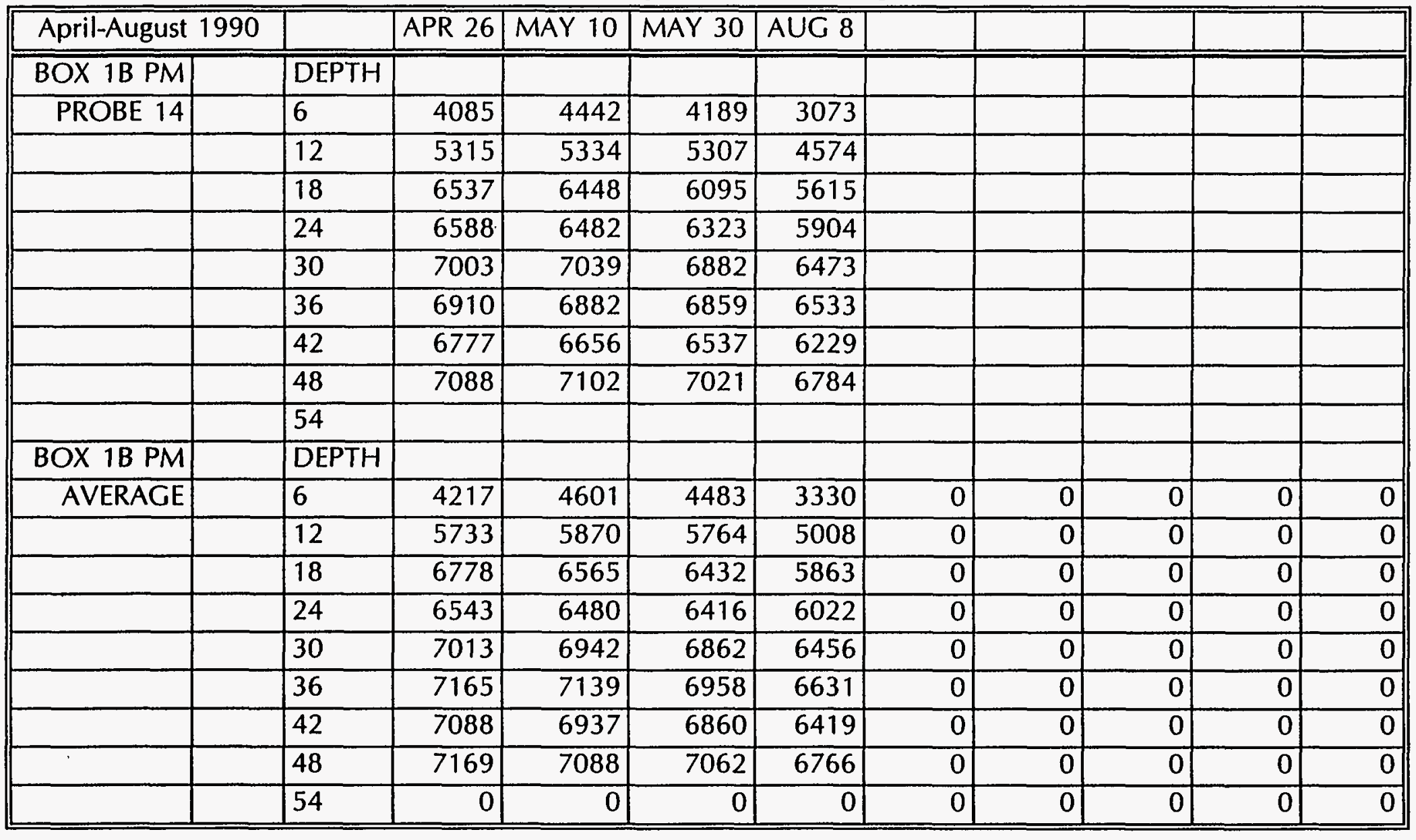


Table B-5. Hydroprobe Readings Observed During Test 5. (sheet 4 of 9)

\begin{tabular}{|r|l|l|r|r|r|r|l|l|l|l|l||}
\hline April-August 1990 & & APR 26 & MAY 10 & MAY 30 & AUG 8 & & & & & \\
\hline \hline BOX 1C CO & & DEPTH & & & & & & & & & \\
\hline PROBE 15 & & 6 & 3538 & 3982 & 3935 & 3009 & & & & & \\
\hline & & 12 & 6022 & 6295 & 5984 & 5145 & & & & & \\
\hline & & 18 & 6875 & 6837 & 6867 & 6127 & & & & & \\
\hline & & 24 & 7585 & 7356 & 7393 & 6695 & & & & & \\
\hline & & 30 & 7645 & 7536 & 7413 & 6738 & & & & & \\
\hline & & 36 & 7314 & 7229 & 7262 & 6464 & & & & & \\
\hline & & 42 & 8490 & 8305 & 7979 & 7425 & & & & & \\
\hline & & 48 & 8466 & 8399 & 8125 & 7617 & & & & & \\
\hline & & 54 & & & & & & & & & \\
\hline BOX 1C CO & & DEPTH & & & & & & & & & \\
\hline PROBE 16 & & 6 & 3820 & 4254 & 4287 & 3536 & & & & & \\
\hline & & 12 & 6113 & 6201 & 6028 & 5243 & & & & & \\
\hline & & 18 & 6637 & 6619 & 6610 & 6070 & & & & & \\
\hline & & 24 & 7676 & 7656 & 7638 & 7020 & & & & & \\
\hline & & 30 & 8242 & 8287 & 8164 & 7327 & & & & & \\
\hline & & 36 & 7840 & 7825 & 7465 & 7056 & & & & & \\
\hline & & 42 & 6976 & 6729 & 6787 & 6241 & & & & & \\
\hline & & 48 & 7087 & 6953 & 7025 & 6538 & & & & & \\
\hline & & 54 & & & & & & & & & \\
\hline
\end{tabular}


Table B-5. Hydroprobe Readings Observed During Test 5. (sheet 5 of 9)

\begin{tabular}{|c|c|c|c|c|c|c|c|c|c|c|}
\hline April-August & & APR 26 & MAY 10 & MAY 30 & AUG 8 & & & & & \\
\hline $\mathrm{BOX} 1 \mathrm{C} \mathrm{CO}$ & DEPTH & & & & & & & & & \\
\hline AVERAGE & 6 & 3679 & 4118 & 4111 & 3273 & 0 & 0 & 0 & 0 & 0 \\
\hline & 12 & 6068 & 6248 & 6006 & 5194 & 0 & 0 & 0 & 0 & 0 \\
\hline & 18 & 6756 & 6728 & 6739 & 6099 & 0 & 0 & 0 & 0 & 0 \\
\hline & 24 & 7631 & 7506 & 7516 & 6858 & 0 & 0 & 0 & 0 & 0 \\
\hline & 30 & 7944 & 7912 & 7789 & 7033 & 0 & 0 & 0 & 0 & 0 \\
\hline & 36 & 7577 & 7527 & 7364 & 6760 & 0 & 0 & 0 & 0 & 0 \\
\hline & 42 & 7733 & 7517 & 7383 & 6833 & 0 & 0 & 0 & 0 & 0 \\
\hline & 48 & 7777 & 7676 & 7575 & 7078 & 0 & 0 & 0 & 0 & 0 \\
\hline & 54 & 0 & 0 & 0 & 0 & 0 & 0 & 0 & 0 & 0 \\
\hline $\mathrm{BOX} 2$ & DEPTH & & & & & & & & & \\
\hline PROBE 21 & 6 & 2398 & 2269 & 2856 & 1523 & & & & & \\
\hline & 12 & 4714 & 4536 & 4645 & 3489 & & & & & \\
\hline & 18 & 5412 & 5163 & 4949 & 4204 & & & & & \\
\hline & 24 & 5607 & 5279 & 5141 & 4484 & & & & & \\
\hline & 30 & 5976 & 5755 & 5604 & 5400 & & & & & \\
\hline & 36 & 6702 & 6805 & 6757 & 6361 & & & & & \\
\hline & 42 & 7475 & 7599 & 7430 & 6975 & & & & & \\
\hline & 48 & 7647 & 7518 & 7454 & 7049 & & & & & \\
\hline & 54 & & & & & & & & & \\
\hline
\end{tabular}


Table B-5. Hydroprobe Readings Observed During Test 5. (sheet 6 of 9)

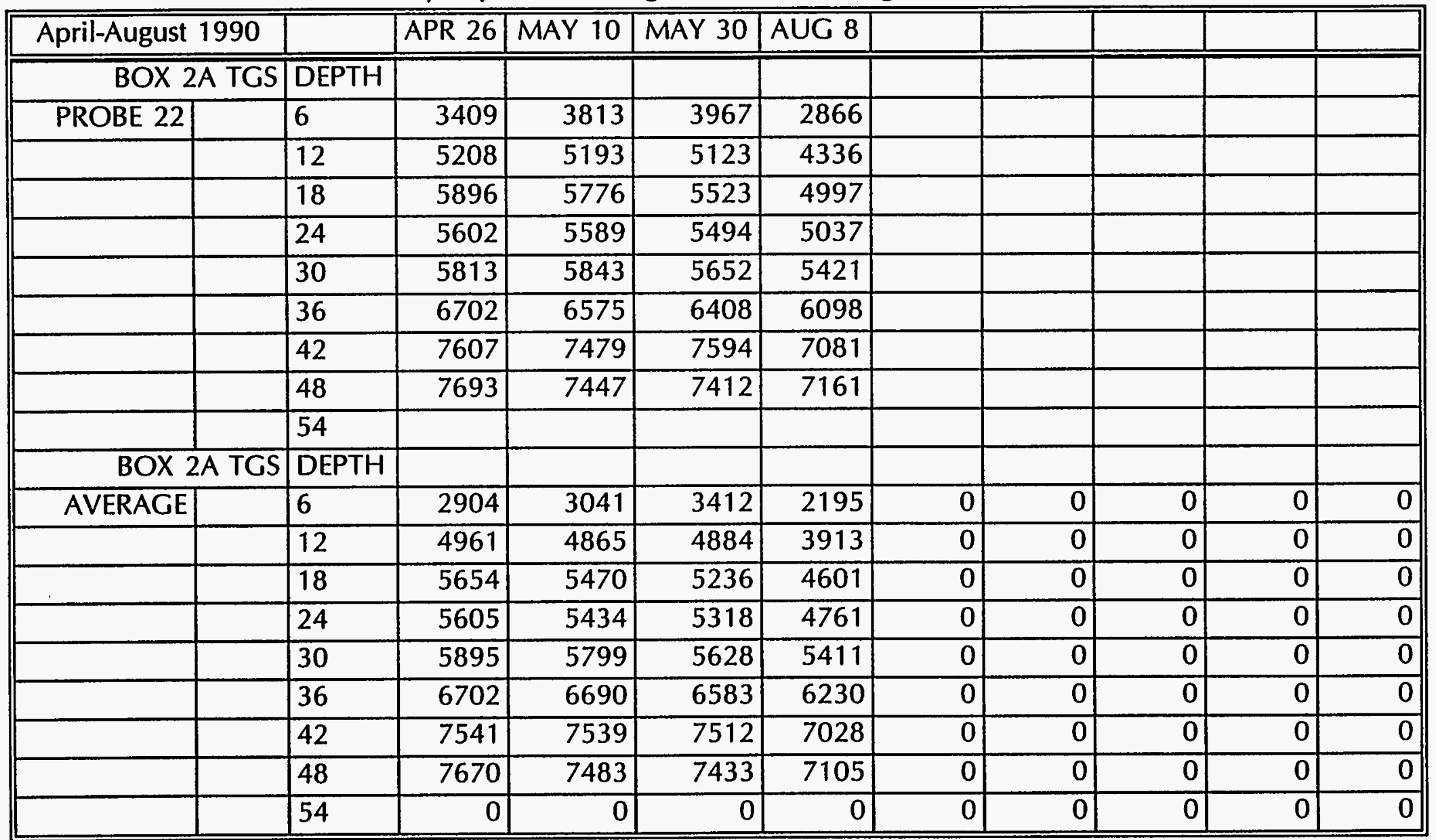


Table B-5. Hydroprobe Readings Observed During Test 5. (sheet 7 of 9)

\begin{tabular}{|c|c|c|c|c|c|c|c|c|c|c|}
\hline April-August & & APR 26 & MAY 10 & MAY 30 & AUG 8 & & & & & \\
\hline $\mathrm{BOX} 2 \mathrm{~B}$ PM & $\overline{\text { DEPTH }}$ & & & & & & & & & \\
\hline PROBE 23 & 6 & 3556 & 3779 & 4174 & 3007 & & & & & \\
\hline & 12 & 5555 & 5474 & 5457 & 4826 & & & & & \\
\hline & 18 & 6275 & 6407 & 6215 & 5727 & & & & & \\
\hline & 24 & 6585 & 6491 & 6394 & 5935 & & & & & \\
\hline & 30 & 6384 & 6172 & 6191 & 5831 & & & & & \\
\hline & 36 & 5994 & 6102 & 5877 & 5637 & & & & & \\
\hline & 42 & 5962 & 6239 & 6172 & 5863 & & & & & \\
\hline & 48 & 6897 & 6868 & 6875 & 6595 & & & & & \\
\hline & 54 & & & & & & & & & \\
\hline BOX 2B PM & DEPTH & & & & & & & & & \\
\hline PROBE 24 & 6 & 4292 & 4028 & 4364 & 3565 & & & & & \\
\hline & 12 & 5647 & 5681 & 5704 & 4835 & & & & & \\
\hline & 18 & 6317 & 6412 & 6253 & 5661 & & & & & \\
\hline & 24 & 6547 & 6376 & 6309 & 5862 & & & & & \\
\hline & 30 & 6503 & 6355 & 6254 & 5931 & & & & & \\
\hline & 36 & 6738 & 6764 & 6664 & 6241 & & & & & \\
\hline & 42 & 6538 & 6602 & 6438 & 6017 & & & & & \\
\hline & 48 & 6643 & 6611 & 6457 & 6402 & & & & & \\
\hline & 54 & & & & & & & & & \\
\hline
\end{tabular}


Table B-5. Hydroprobe Readings Observed During Test 5. (sheet 8 of 9)

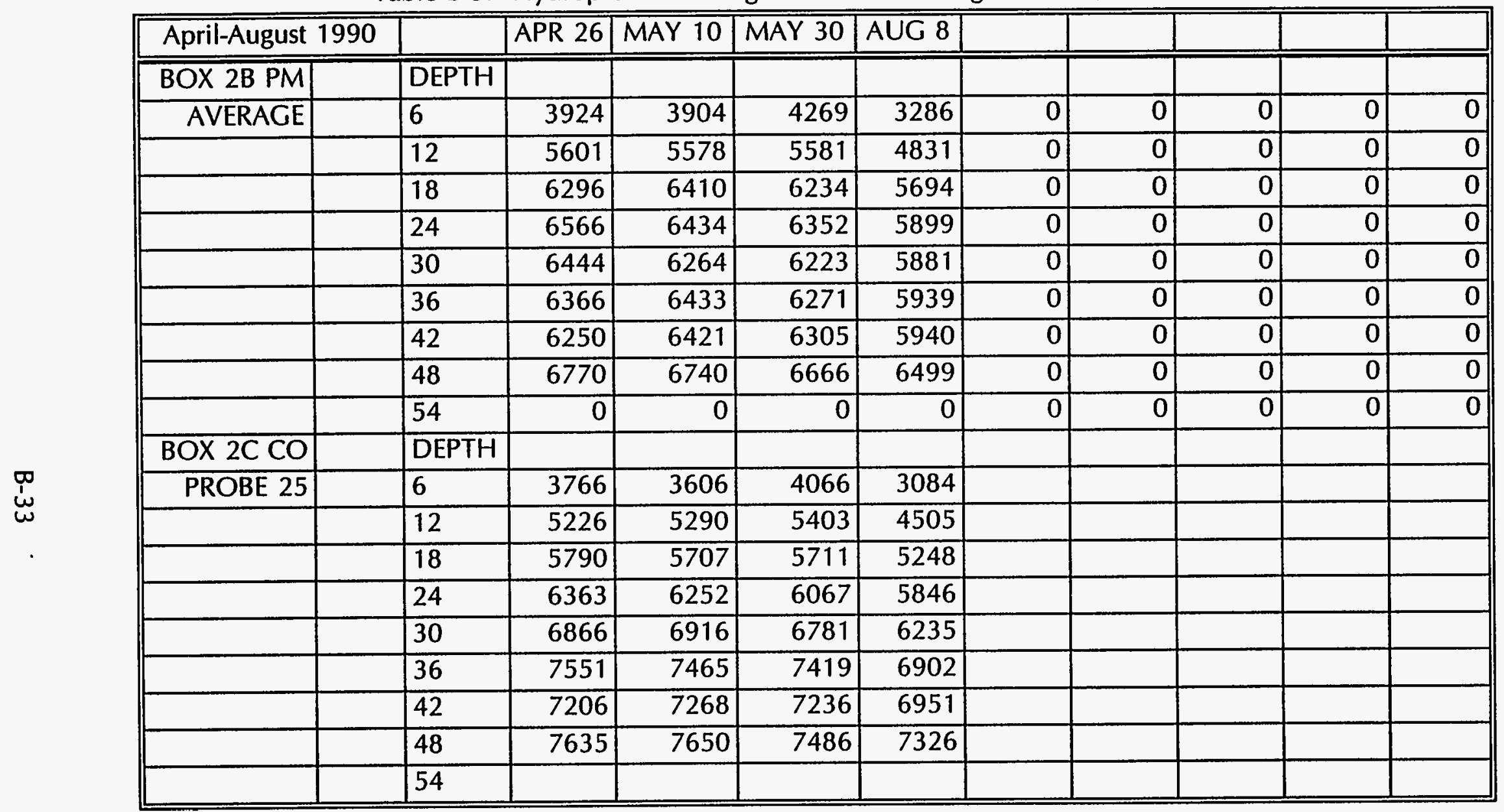


Table B-5. Hydroprobe Readings Observed During Test 5. (sheet 9 of 9)

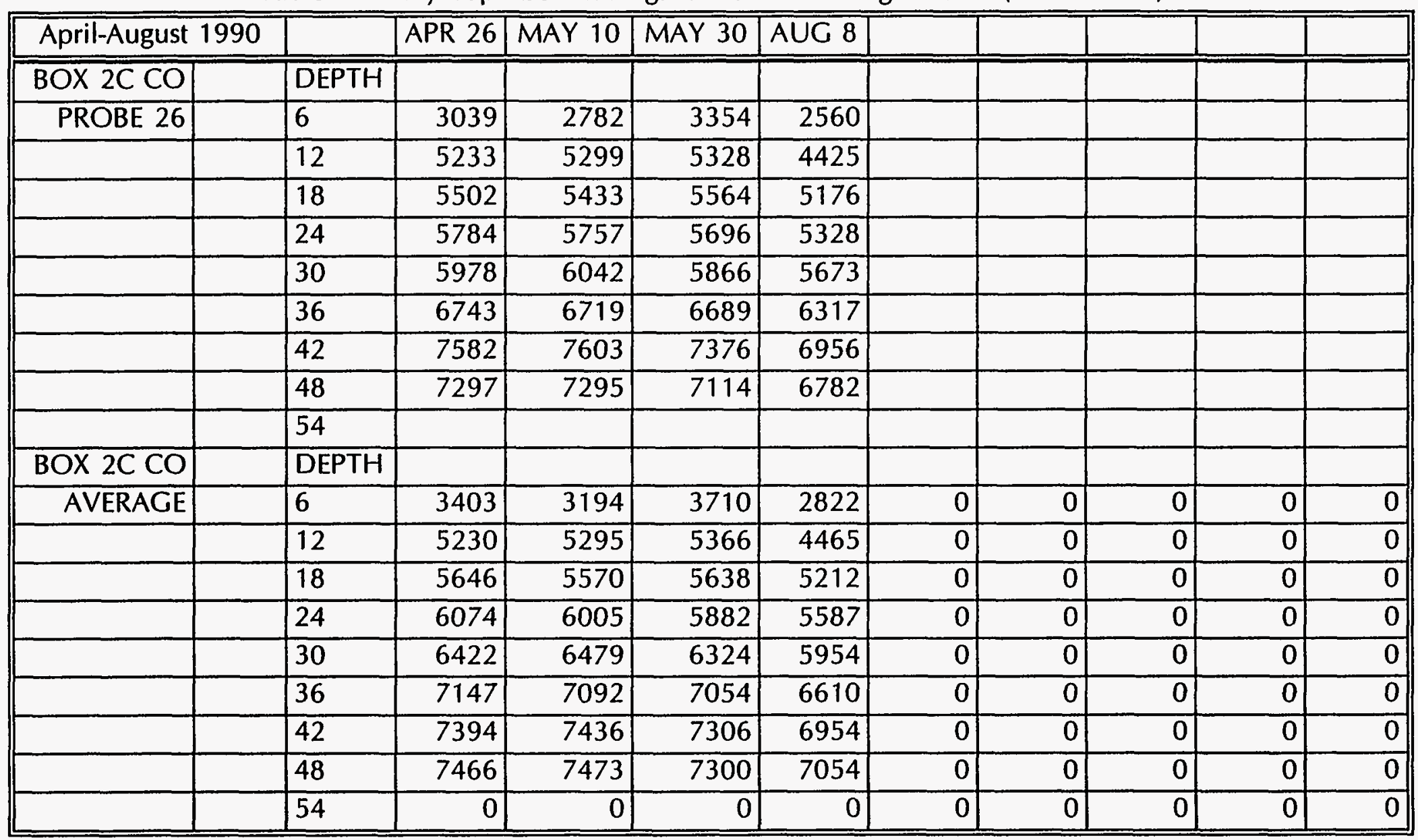




\section{APPENDIX C}

\section{SOIL MOISTURE GRAPHS GENERATED FROM GRAVIMETRIC} SOIL SAMPLING FOR TESTS

C-1 
Figure C-1. Soil Moisture Profile Changes (Test 1) (Pocket Mouse with No Supplemental Precipitation).

\section{Soil Moisture Profile Changes (Test 1)}

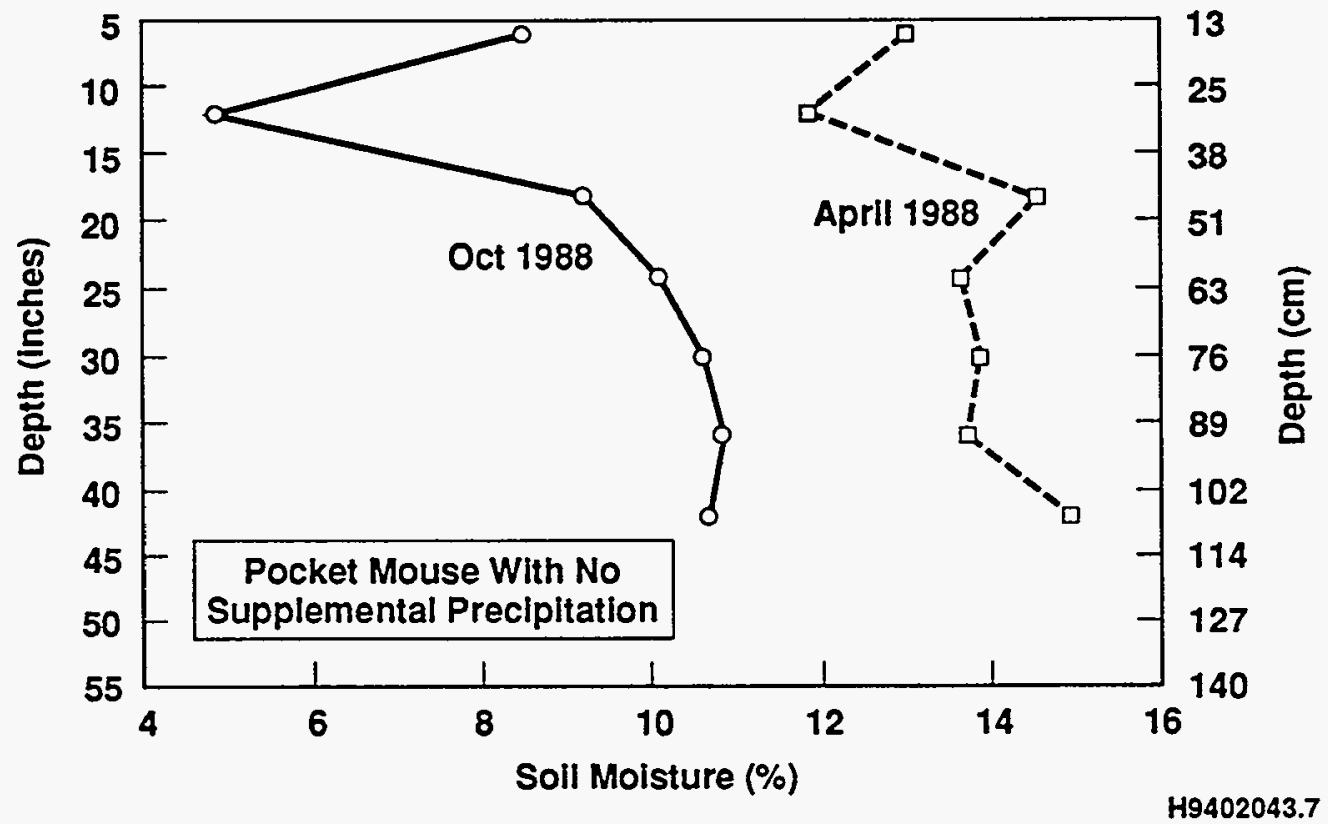

Figure C-2. Soil Moisture Profile Changes (Test 1)

[Control (No Animal) with No Supplemental Precipitation].

\section{Soil Moisture Profile Changes (Test 1)}

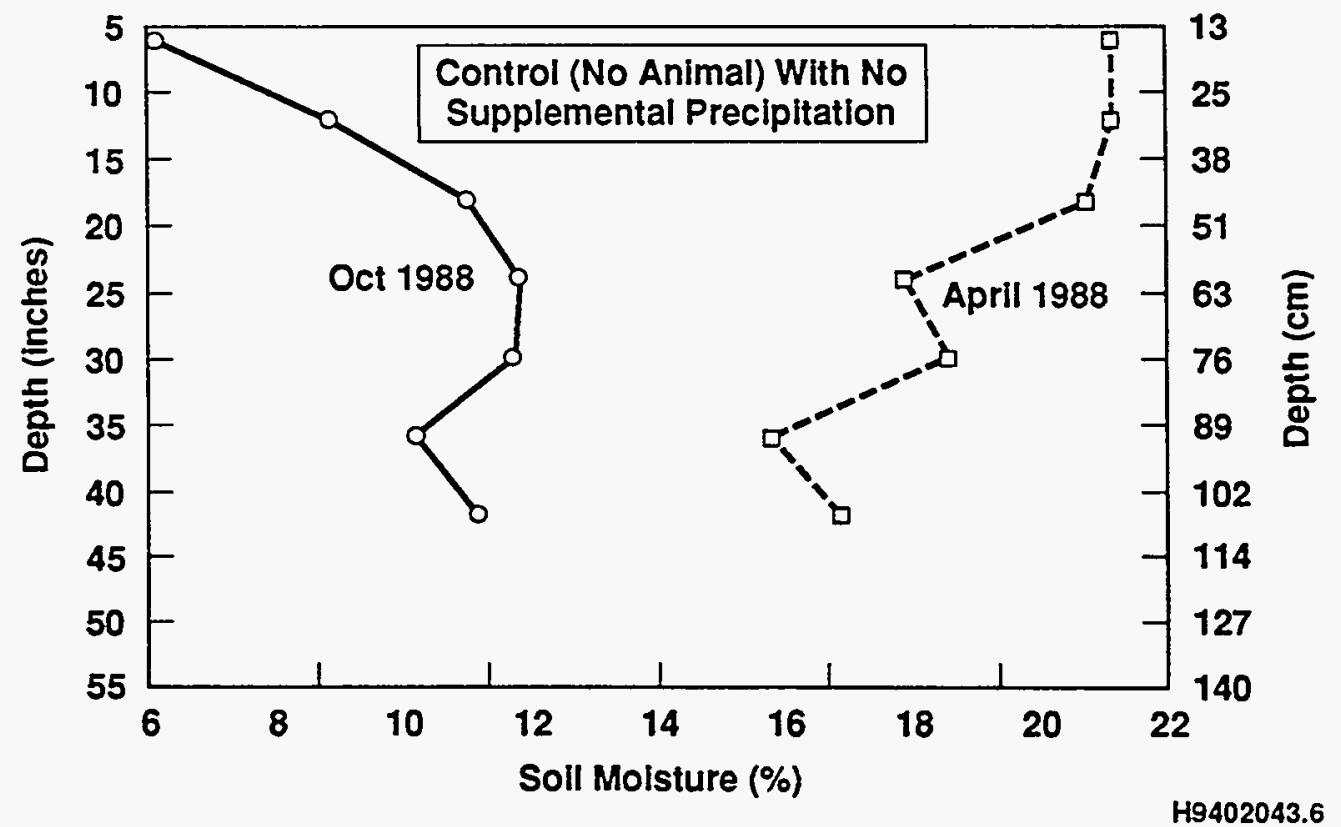


Figure C-3. Soil Moisture Profile Changes (Test 1)

[Control (No Animal) with No Supplemental Precipitation].

\section{Soil Moisture Profile Changes (Test 1)}

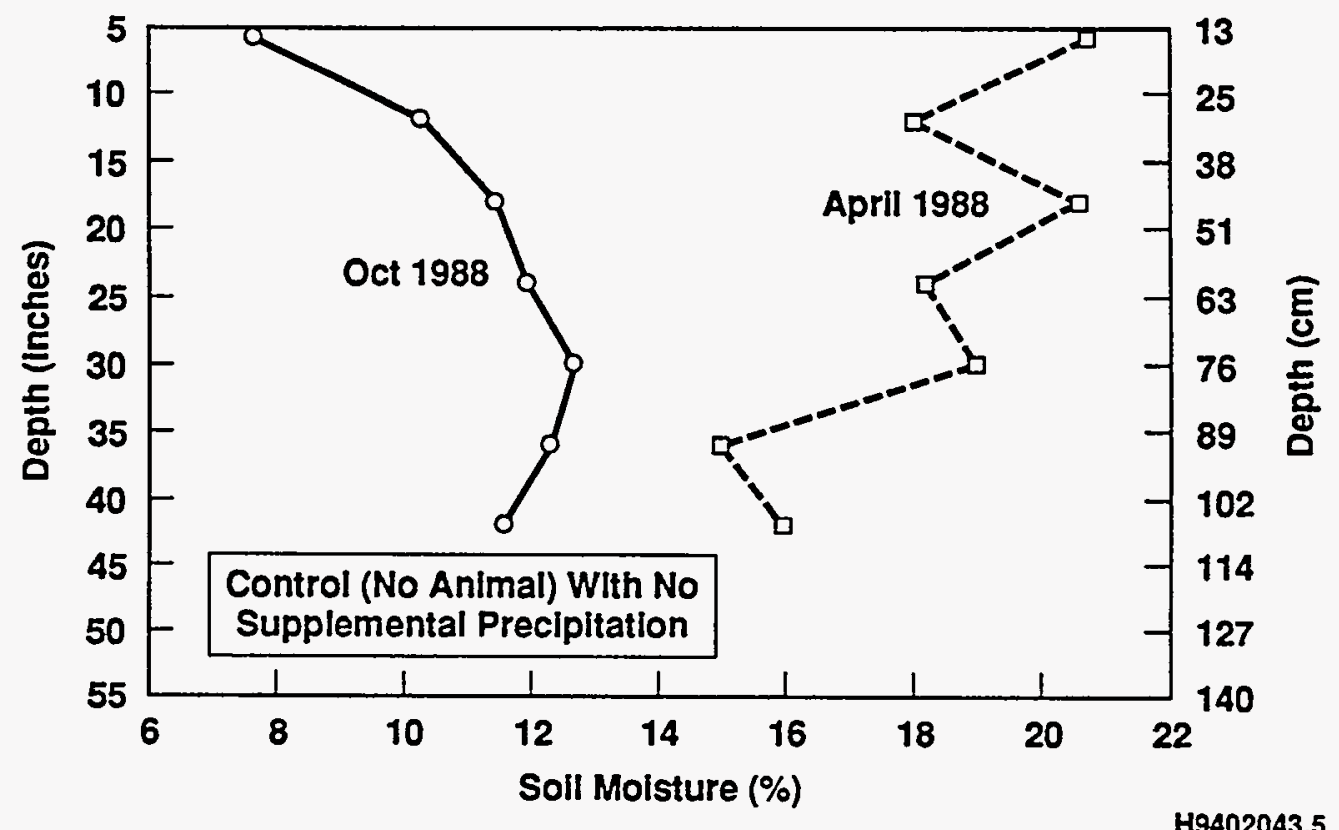

Figure C-4. Soil Moisture Profile Changes (Test 1)

(Townsend with Supplemental Precipitation).

\section{Soil Moisture Profile Changes (Test 1)}

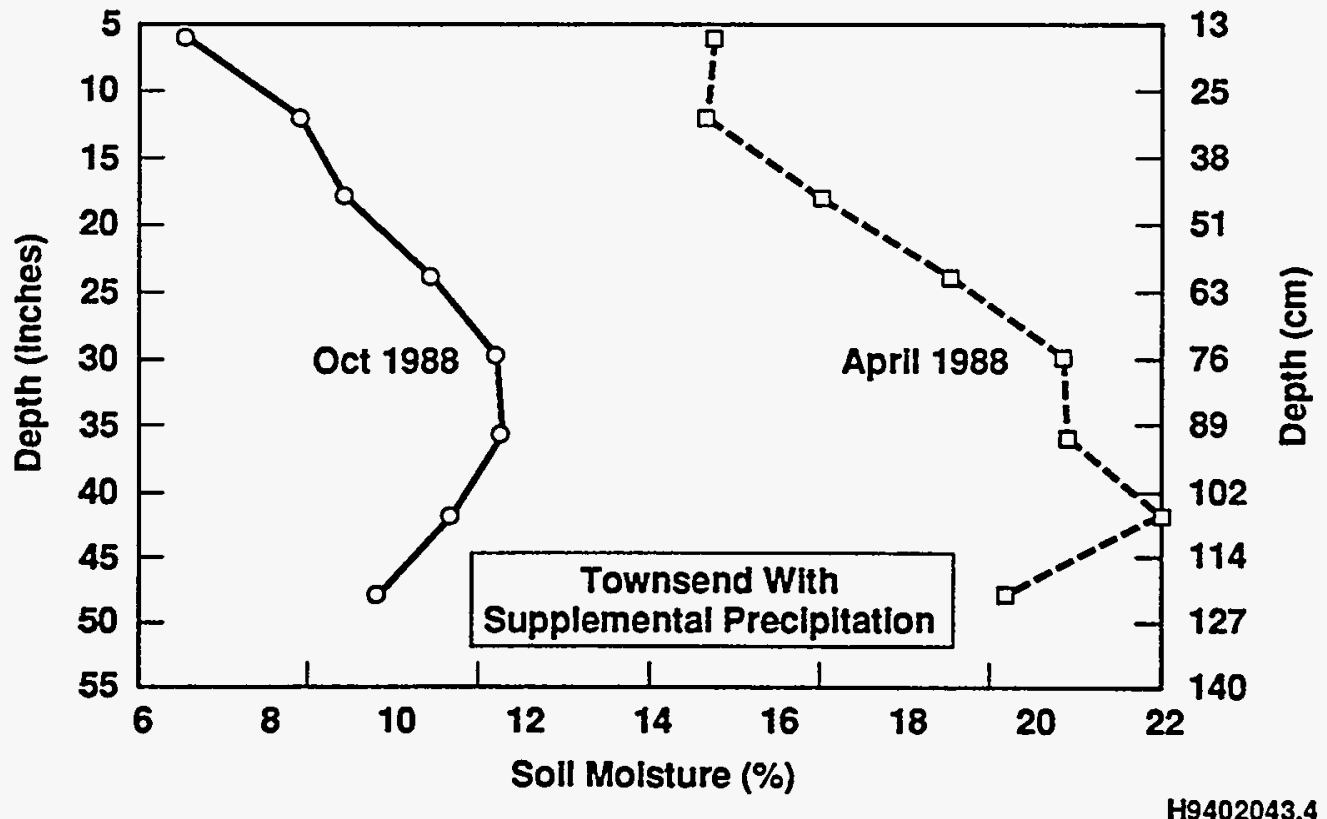


WHC-EP-0730

Figure C-5. Soil Moisture Profile Changes (Test 1)

[Control (No Animal) with Supplemental Precipitation].

Soil Moisture Profile Changes (Test 1)

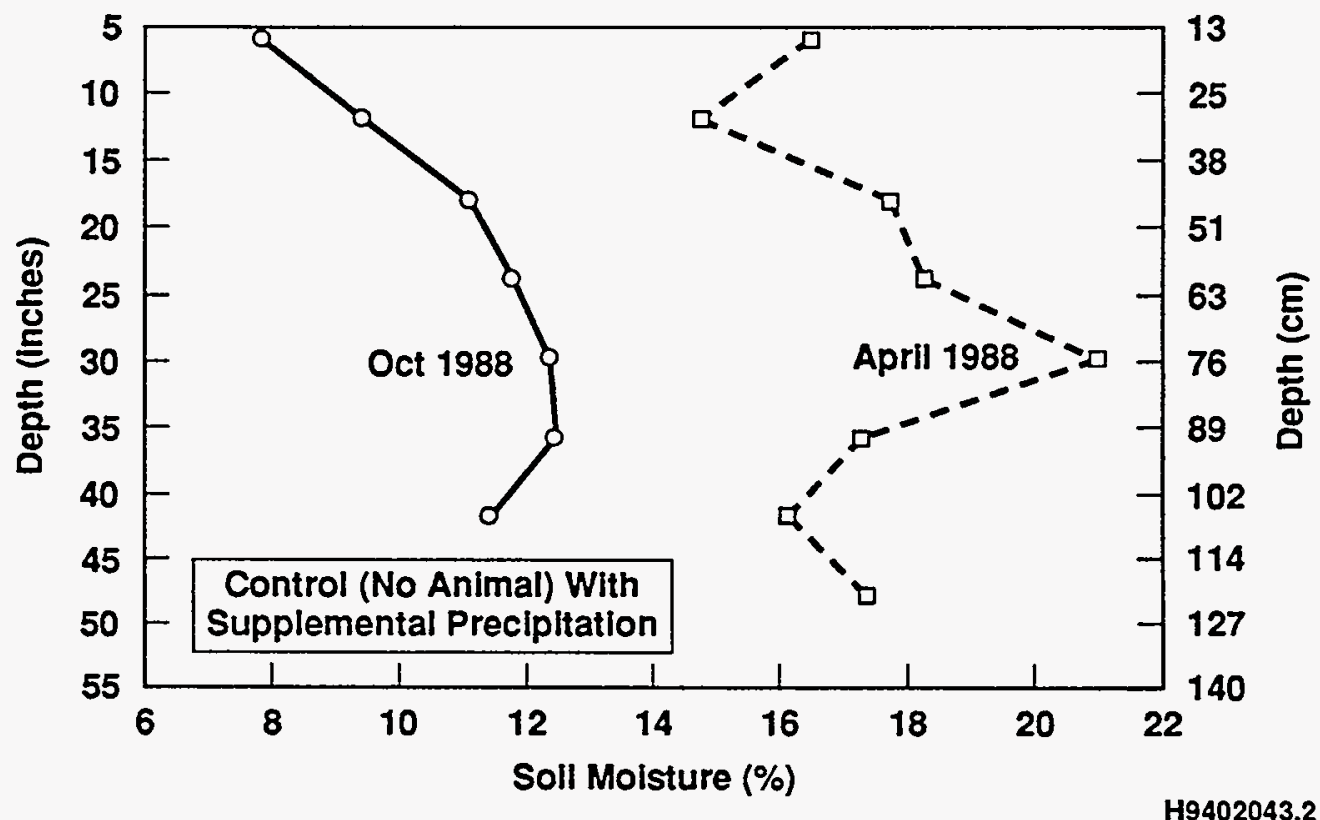

Figure C-6. Soil Moisture Profile Changes (Test 1) (Pocket Mouse with Supplemental Precipitation).

\section{Soil Moisture Profile Changes (Test 1)}

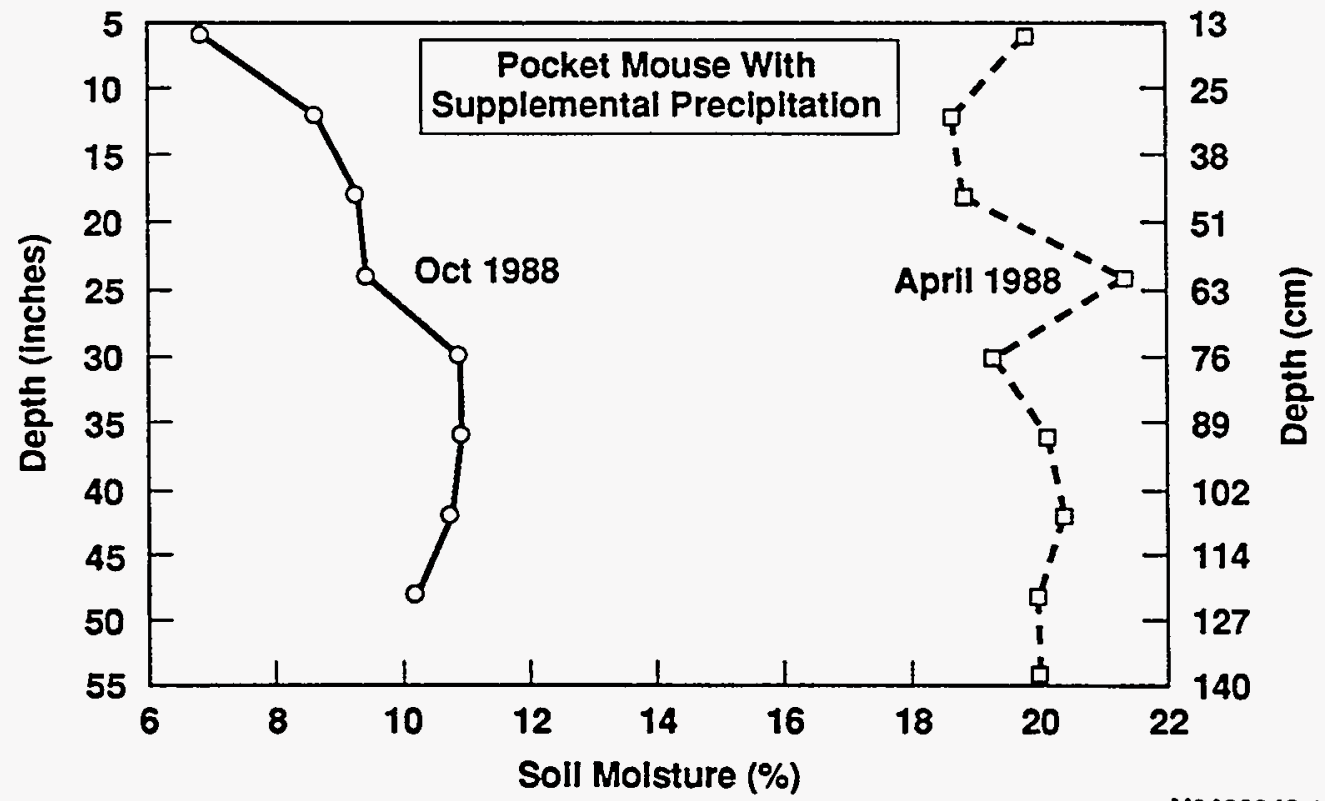

H9402043.1 
Figure C-7. Soil Moisture Profile Changes (Test 2)

[Pocket Gopher with Ambient Precipitation (Winter)].

\section{Soil Moisture Profile Changes (Test 2)}

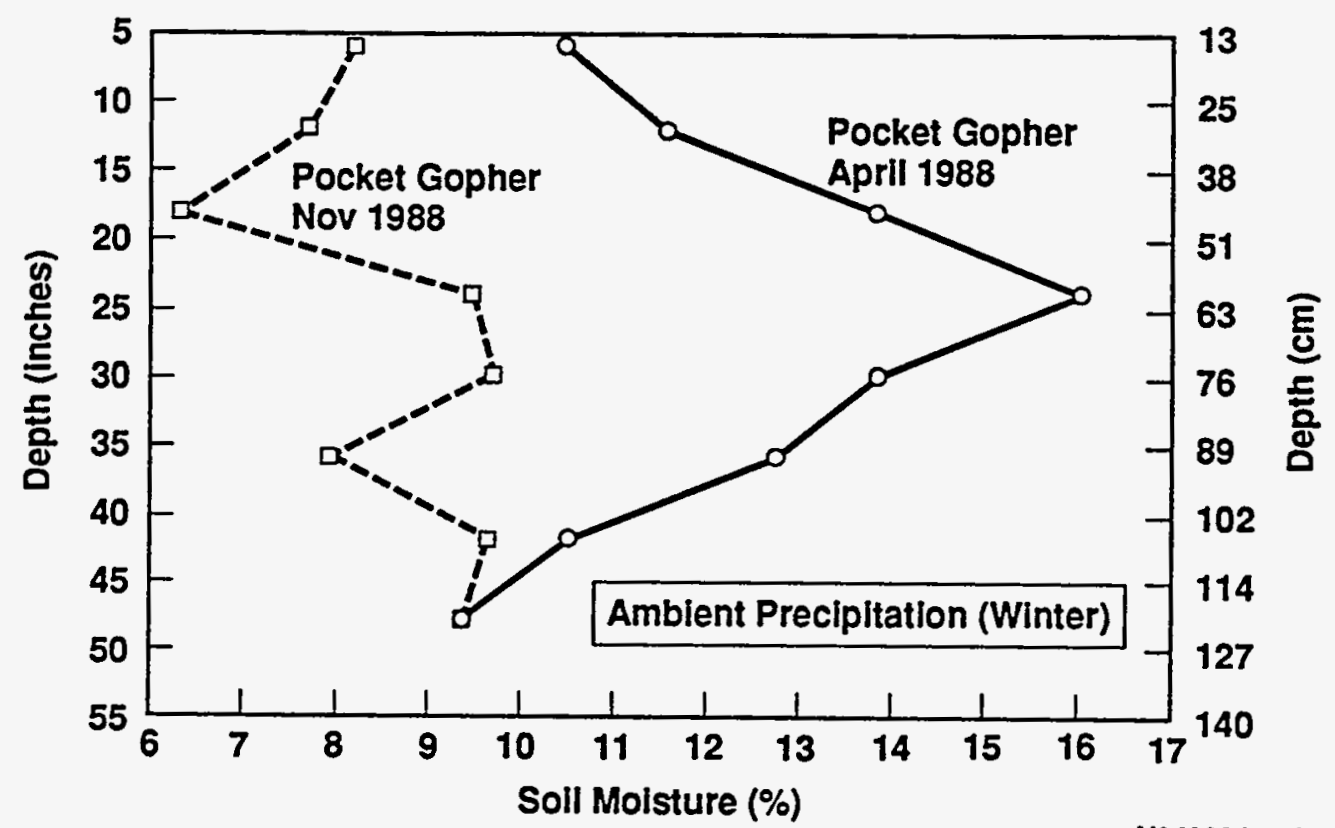

Figure C-8. Soil Moisture Profile Changes (Test 2) [Pocket Gopher with Ambient Precipitation (Winter)].

\section{Soil Moisture Profile Changes (Test 2) Ambient Precipitation (Winter)}

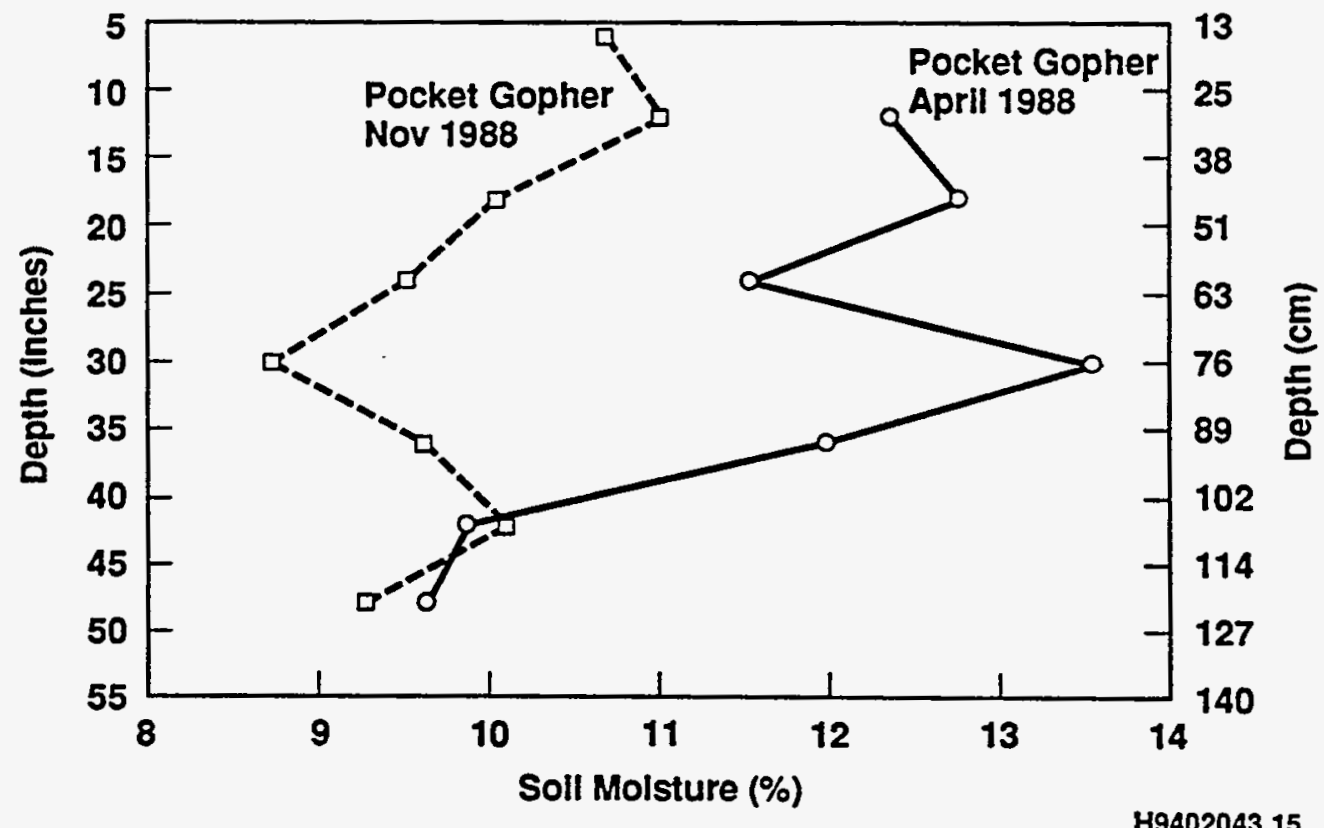


Figure C-9. Soil Moisture Profile Changes (Test 2)

[Control (No Animal) with Ambient Precipitation (Winter)].

\section{Soil Moisture Profile Changes (Test 2) Ambient Precipitation (Winter)}

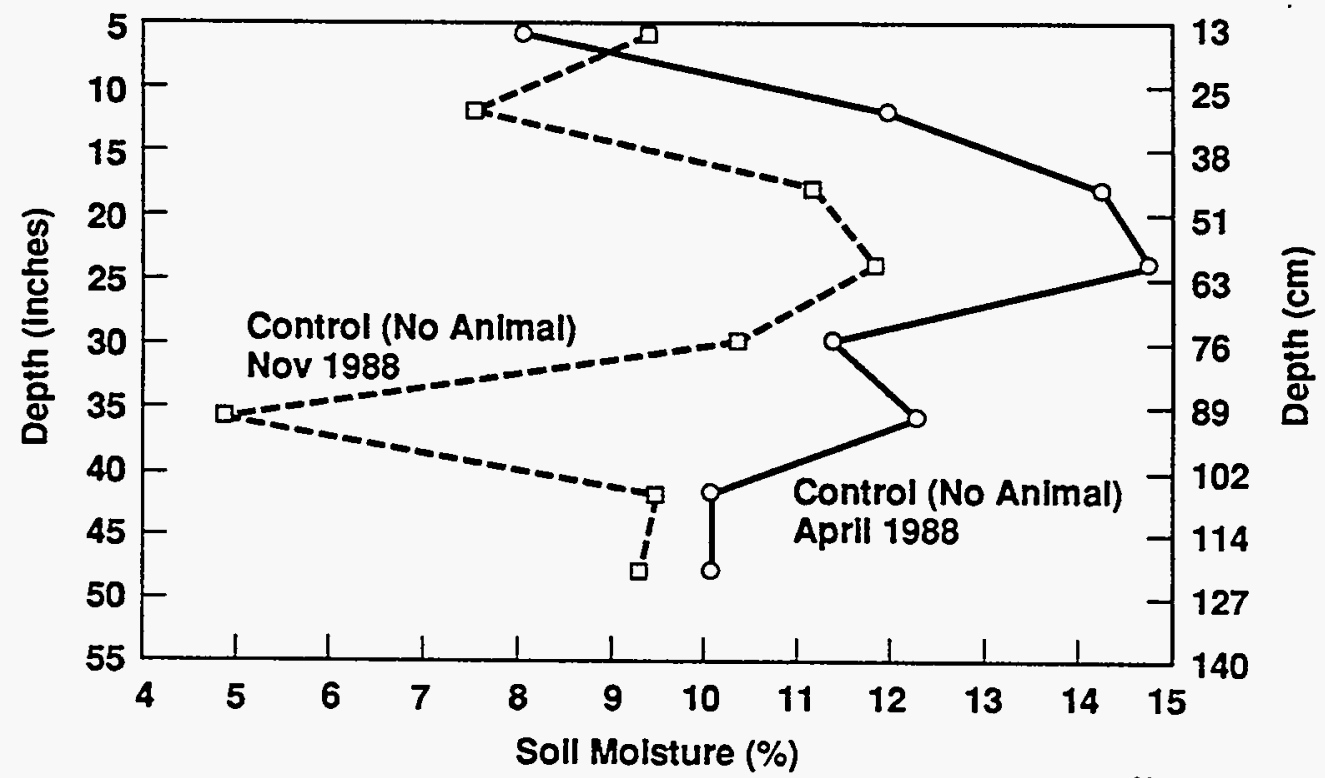

H9402043.16

Figure C-10. Soil Moisture Profile Changes (Test 2) [Pocket Mouse with Ambient Precipitation (Winter)].

\section{Soil Moisture Profile Changes (Test 2) Ambient Precipitation (Winter)}

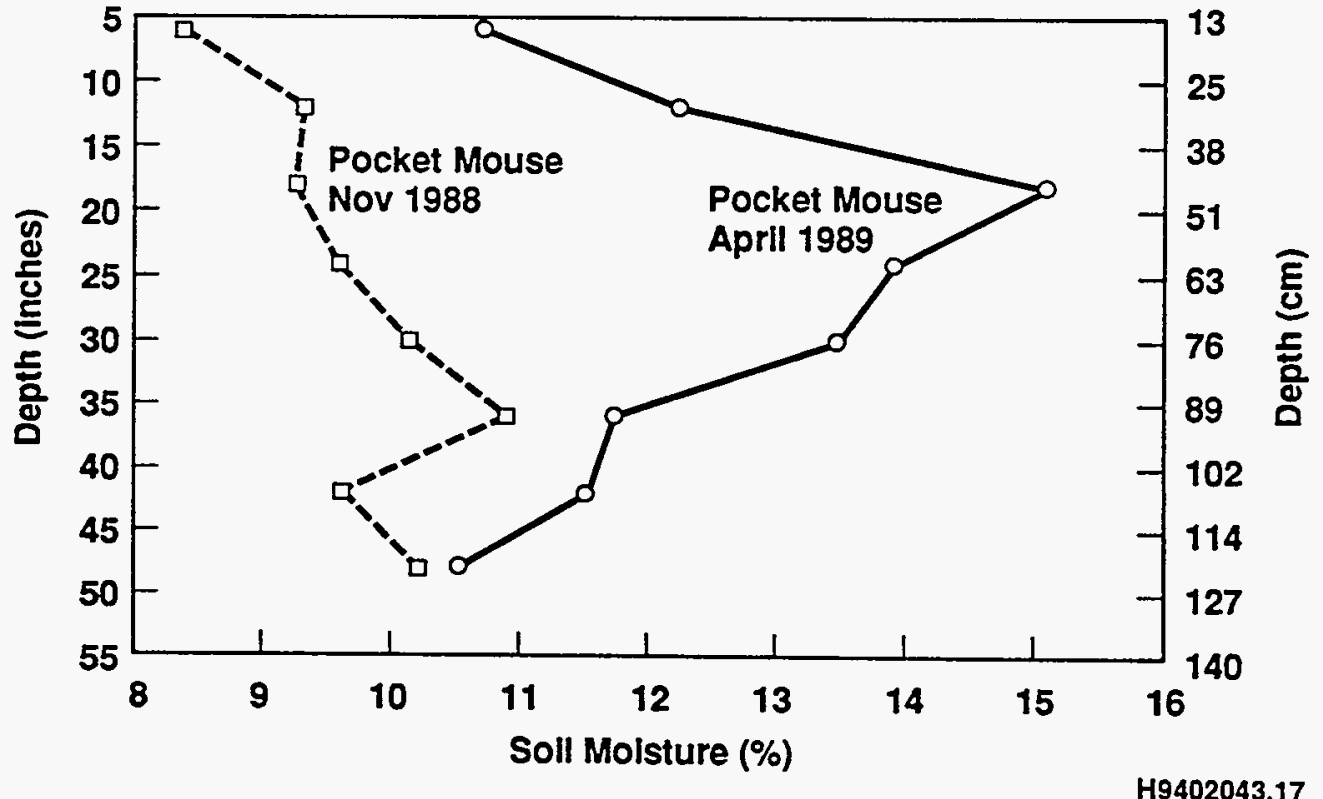


Figure C-11. Soil Moisture Profile Changes (Test 2)

[Control (No Animal) with No Supplemental Precipitation].

Soil Moisture Profile Changes (Test 3) Control (No Animal) No Supplemental Precipitation

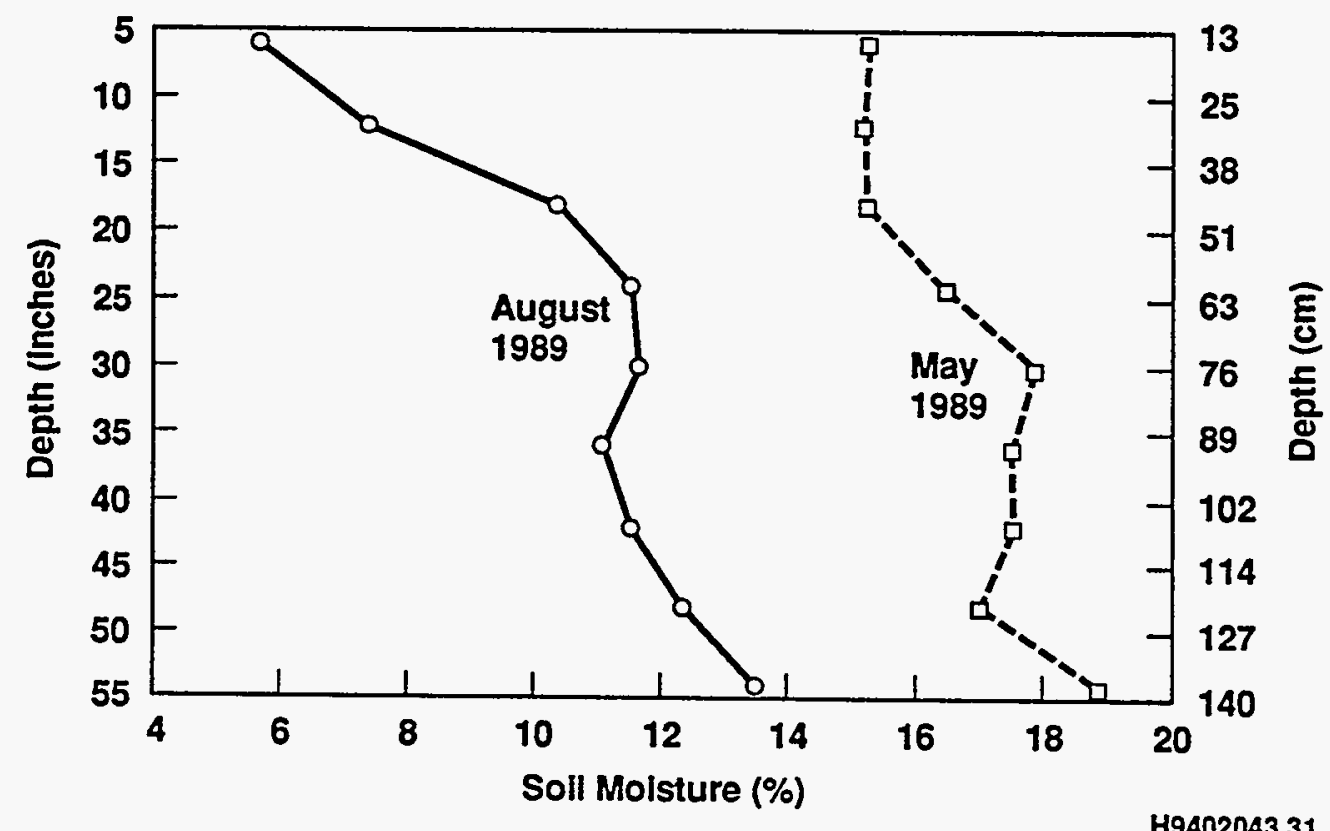

Figure C-12. Soil Moisture Profile Changes (Test 3) (Pocket Gopher with No Supplemental Precipitation).

\section{Soil Moisture Profile Changes (Test 3) \\ Pocket Gopher (No Supplemental Precipitation)}

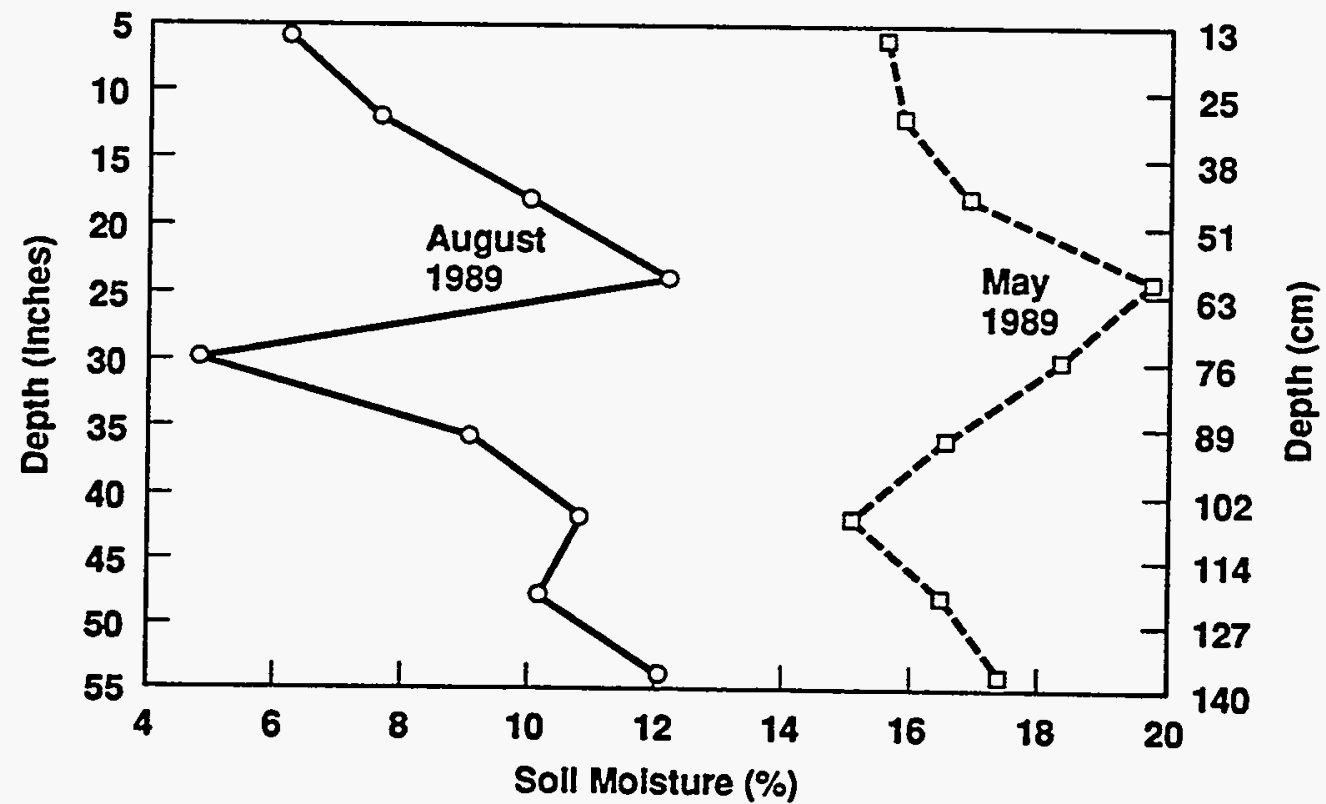

H9402043.32 
Figure C-13. Soil Moisture Profile Changes (Test 3)

(Townsend with No Supplemental Precipitation).

\section{Soil Moisture Profile Changes (Test 3) Townsend (No Supplemental Precipitation)}

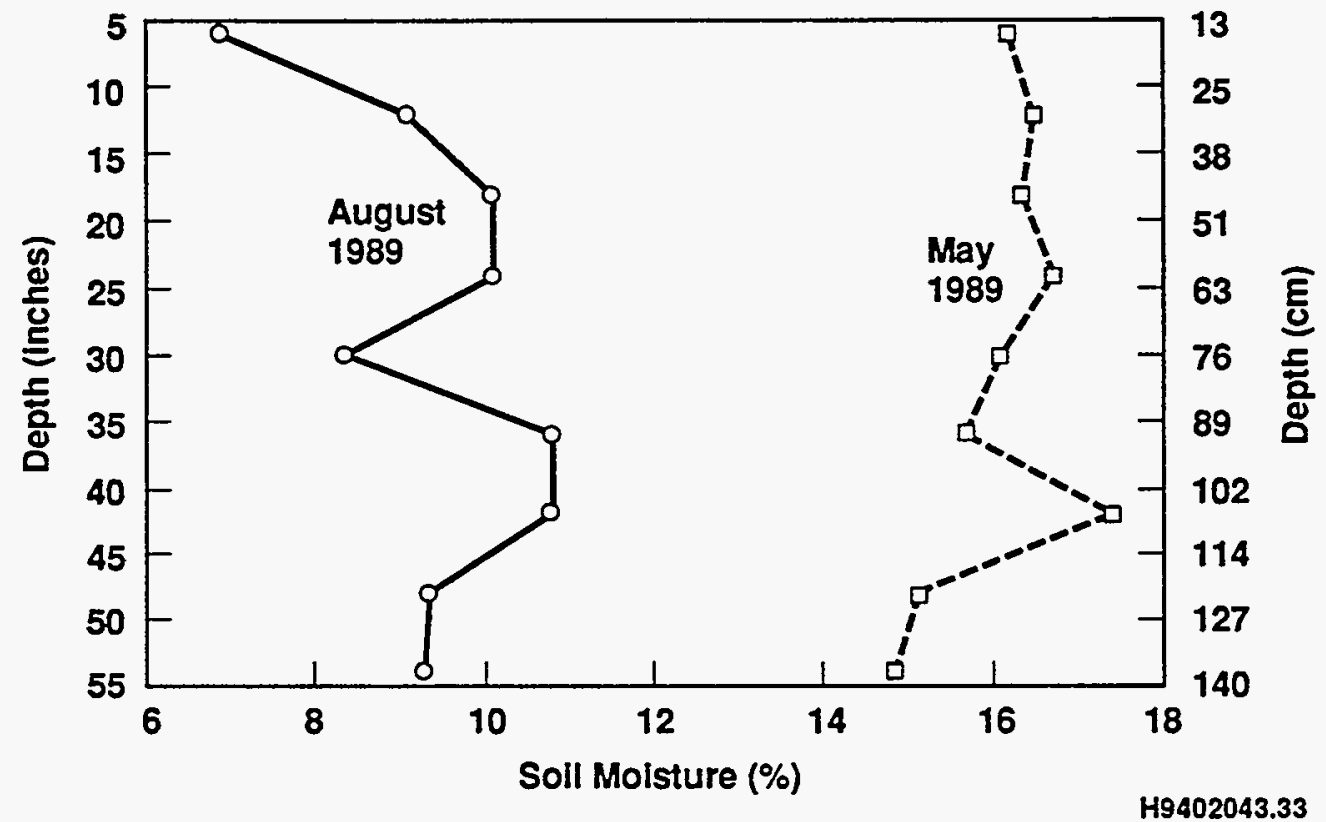

Figure C-14. Soil Moisture Profile Changes (Test 3)

(Townsend with Supplemental Precipitation).

\section{Soil Moisture Profile Changes (Test 3)}

Townsend (Supplemental Precipitation)

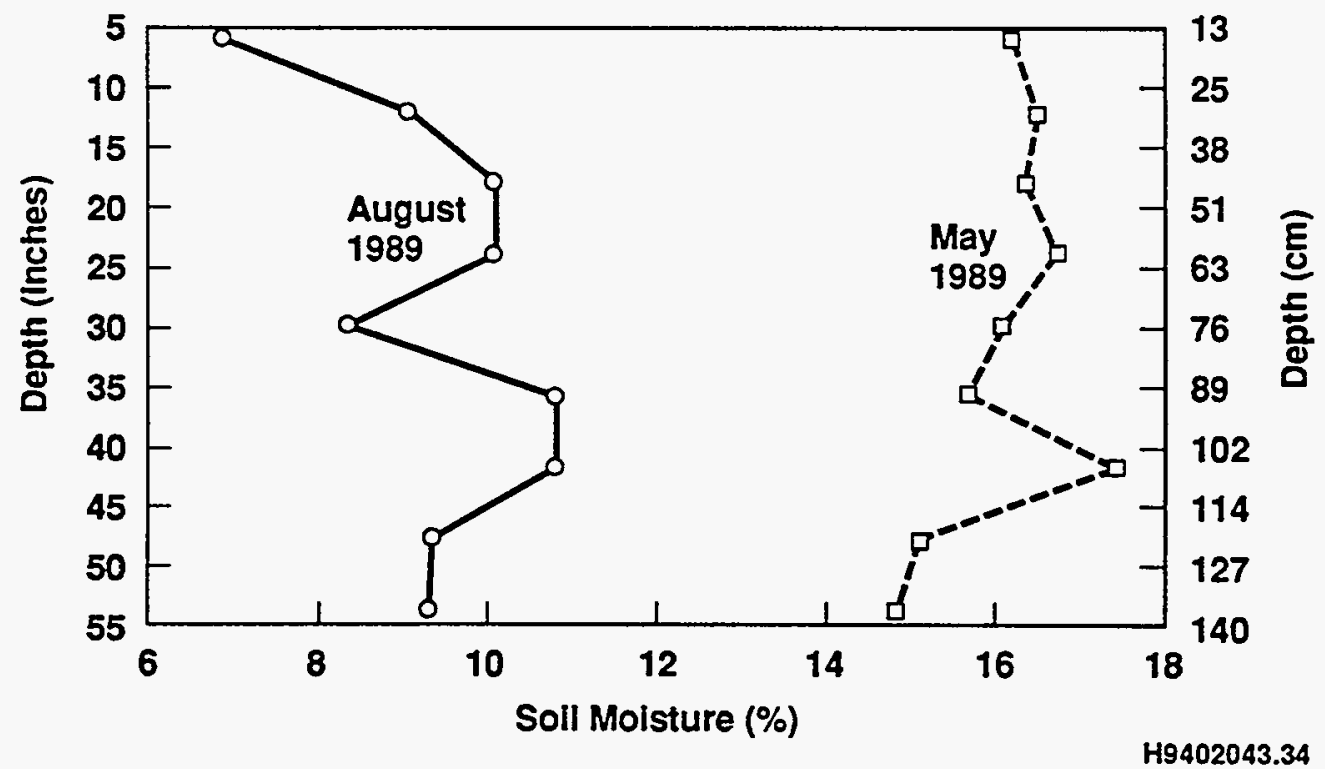


WHC-EP-0730

Figure C-15. Soil Moisture Profile Changes (Test 3)

[Control (No Animal) with Supplemental Precipitation].
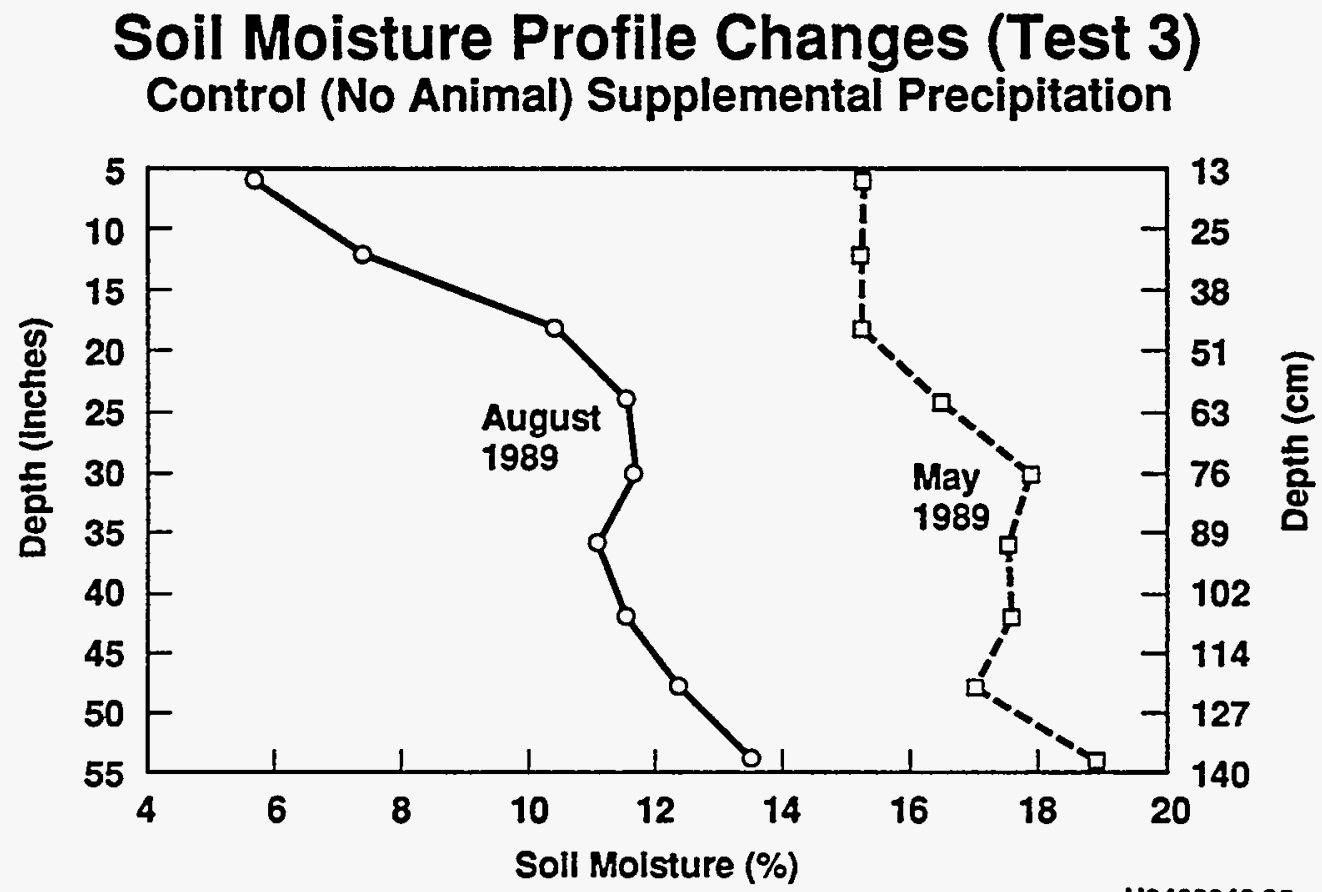

Figure C-16. Soil Moisture Profile Changes (Test 3) (Pocket Gopher with Supplemental Precipitation).

\section{Soil Moisture Profile Changes (Test 3)}

Pocket Gopher (Supplemental Precipitation)

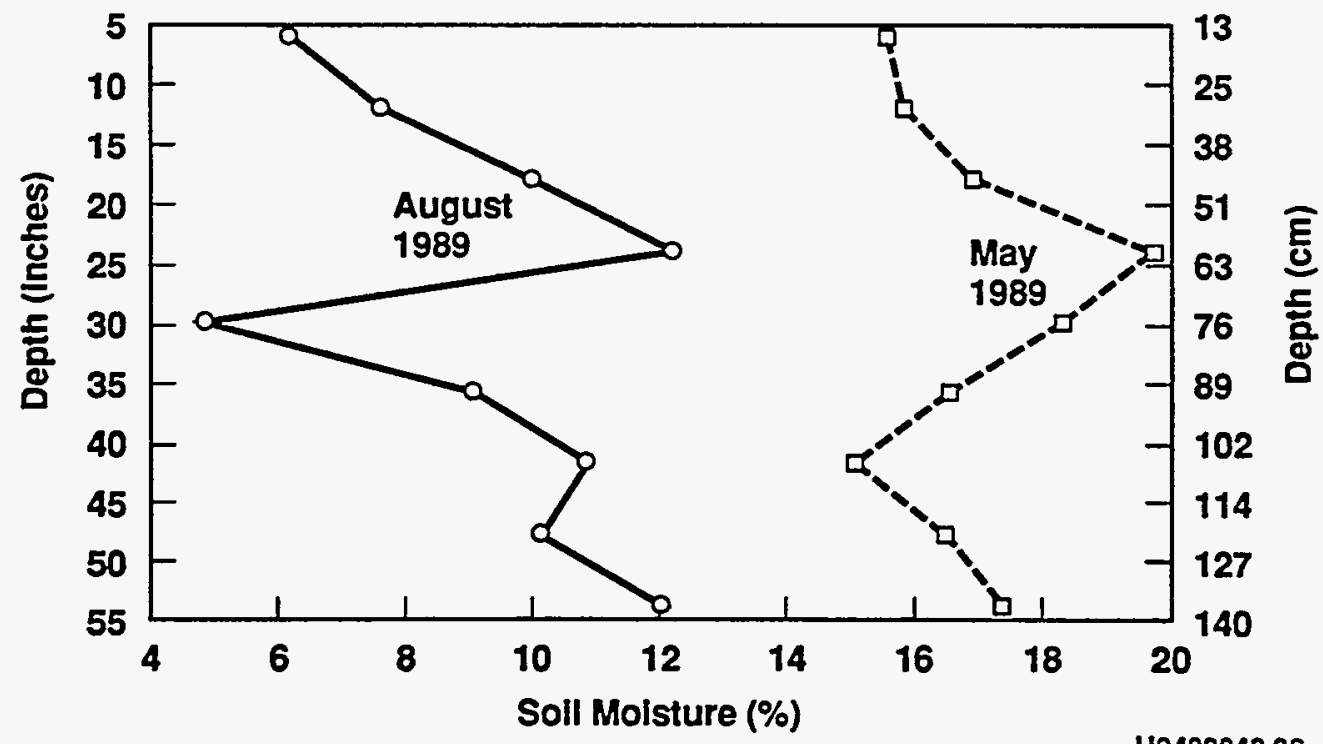


Figure C-17. Soil Moisture Profile Changes (Test 4) (Pocket Mouse with Supplemental Precipitation).

\section{Soil Moisture Profile Changes (Test 4)} Pocket Mouse (Supplemental Precipitation)

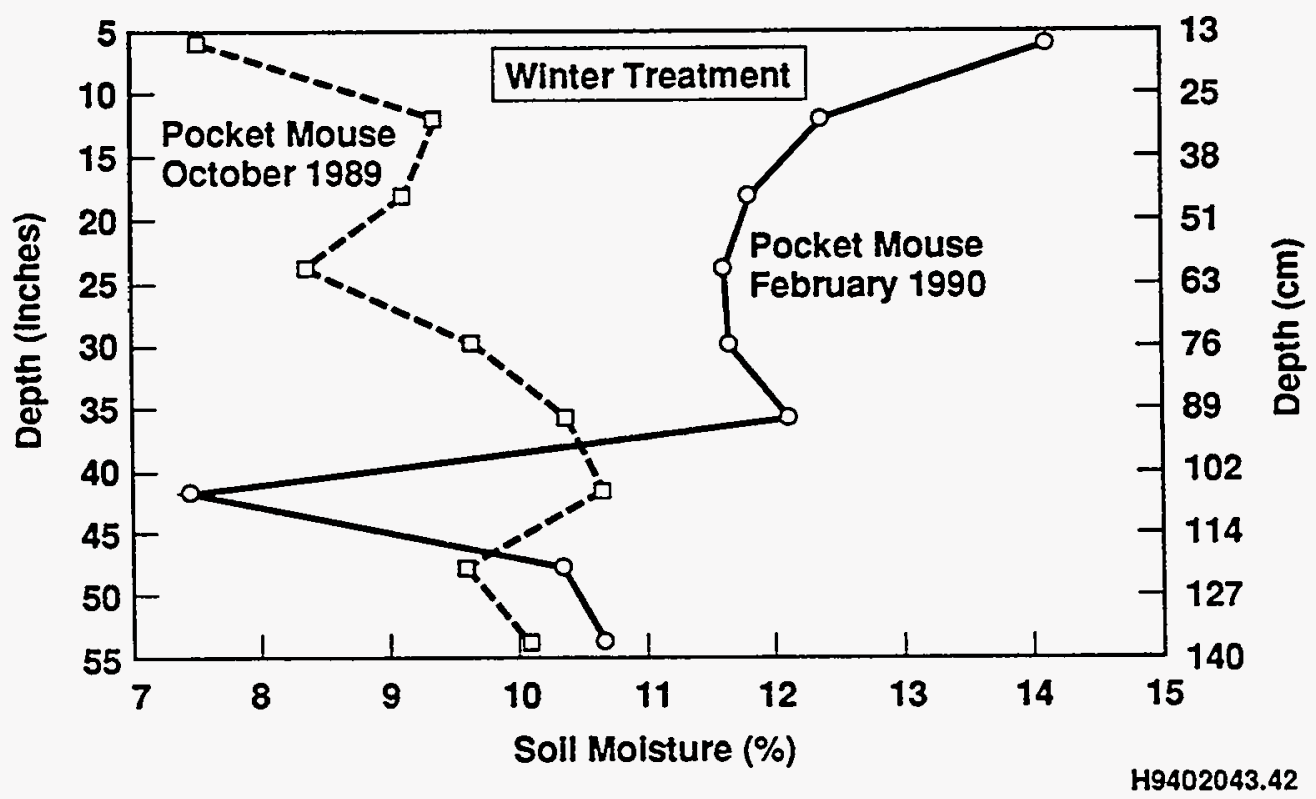

Figure C-18. Soil Moisture Profile Changes (Test 4) [Control (No Animal) with Supplemental Precipitation].
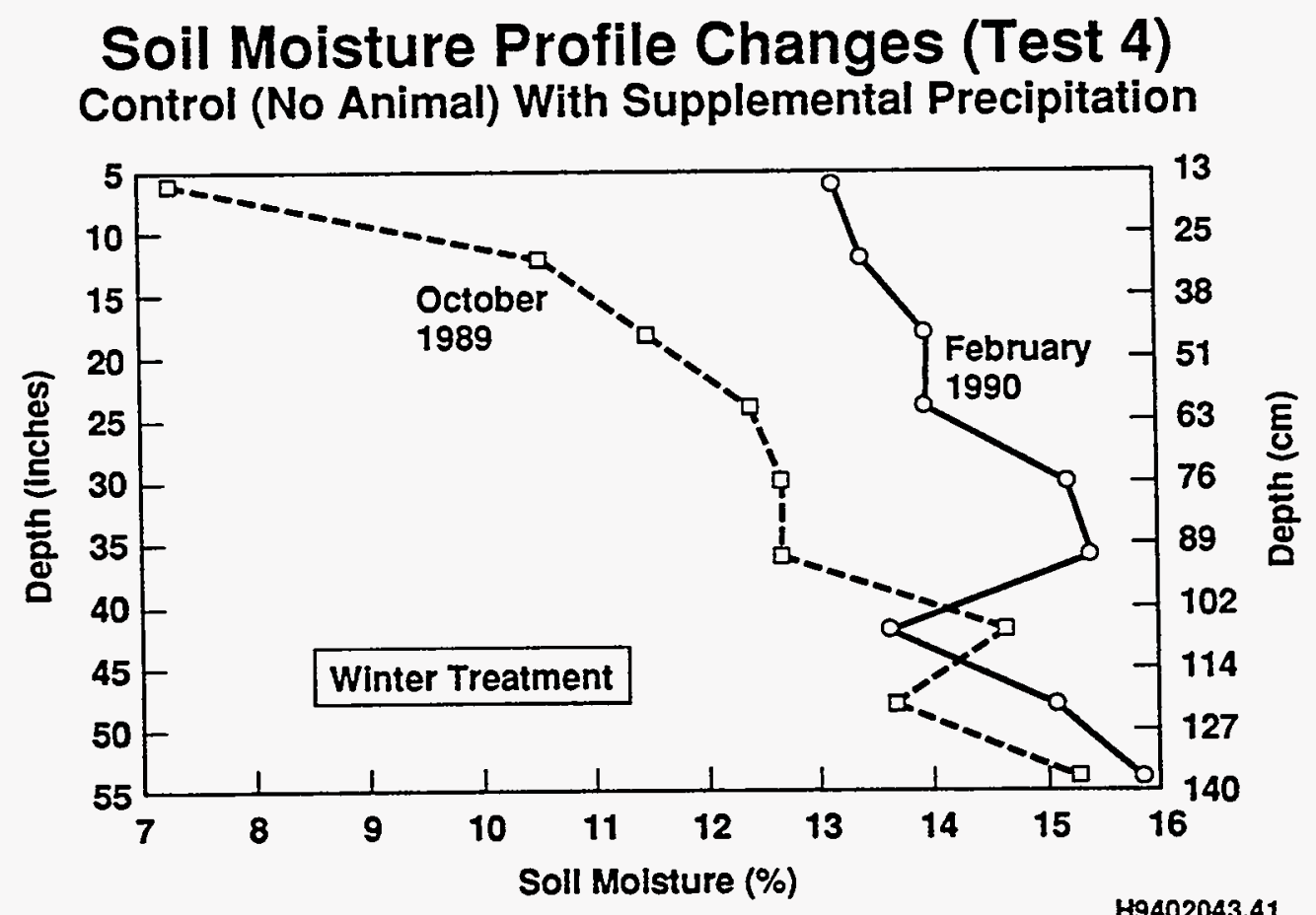
Figure C-19. Soil Moisture Profile Changes (Test 4) (Pocket Gopher with No Supplemental Precipitation).

\section{Soil Moisture Profile Changes (Test 4)}

Pocket Gopher (No Supplemental Precipitation)

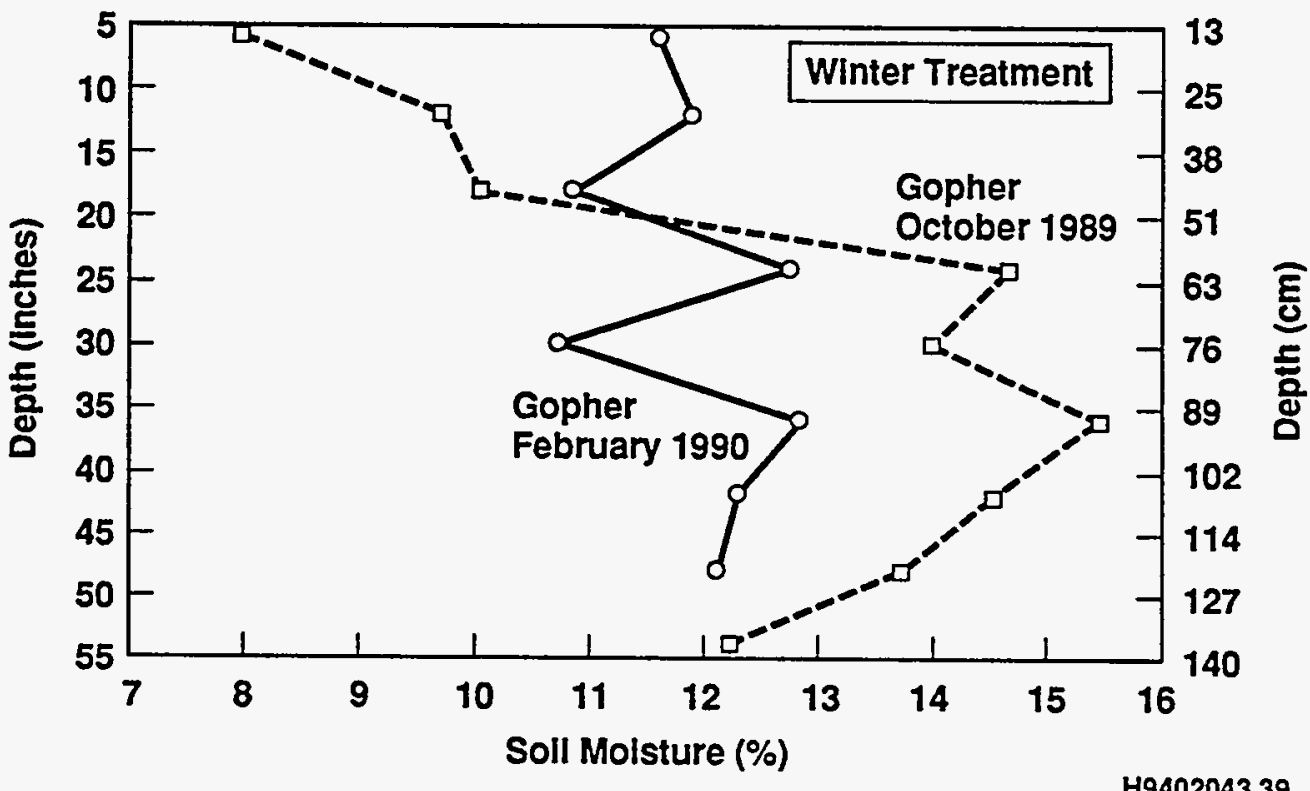

Figure C-20. Soil Moisture Profile Changes (Test 4) (Pocket Mouse with No Supplemental Precipitation).

\section{Soil Moisture Profile Changes (Test 4) Pocket Mouse (No Supplemental Precipitation)}

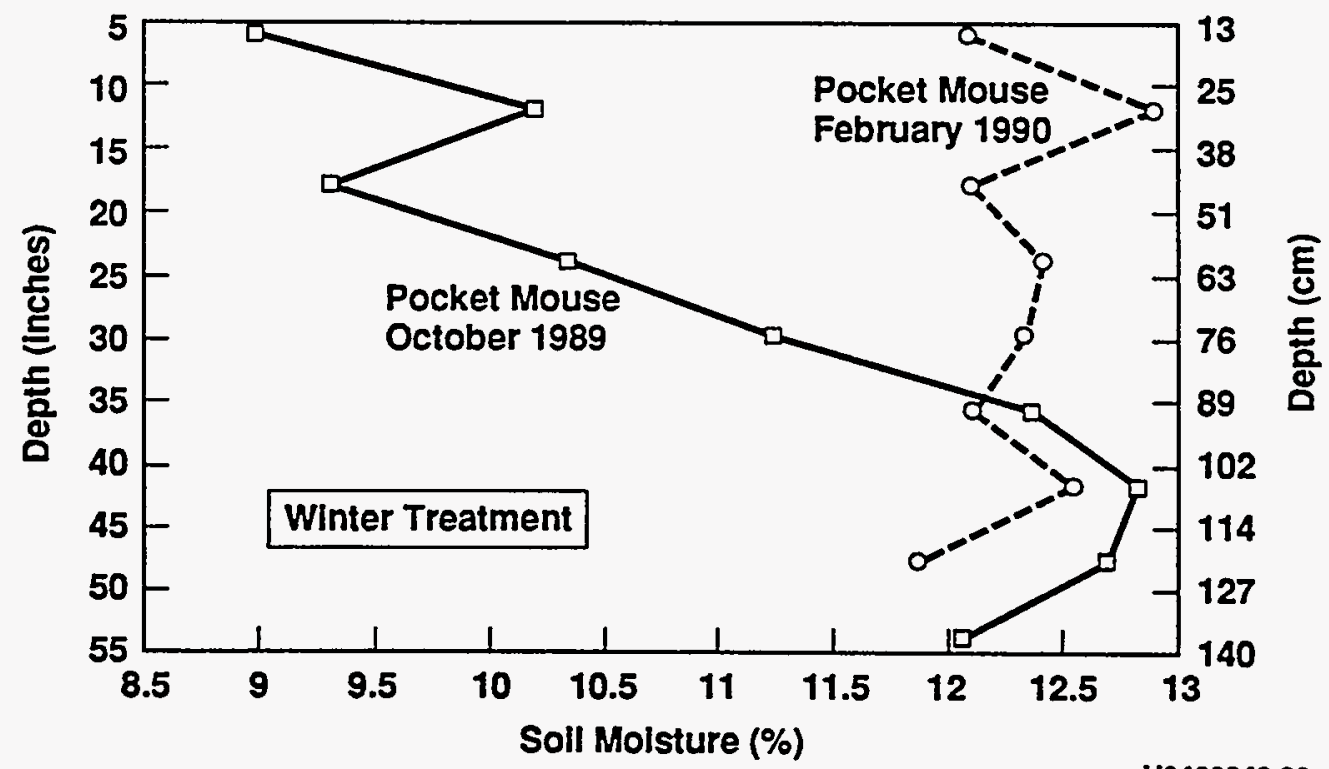


Figure C-21. Soil Moisture Profile Changes (Test 4)

[Control (No Animal) with Supplemental Precipitation].

\section{Soil Moisture Profile Changes (Test 4)}

Control (No Animal) Supplemental Precipitation

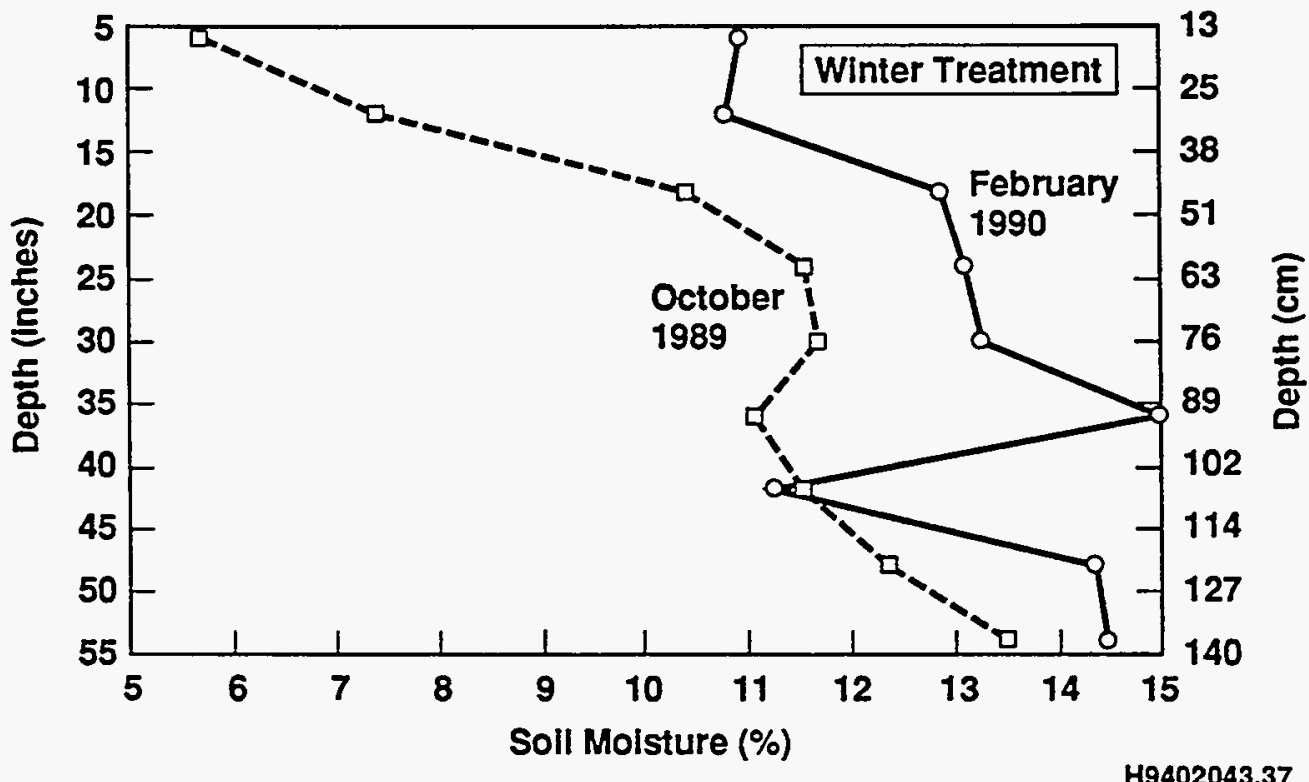

Figure C-22. Soil Moisture Profile Changes (Test 5)

[Control (No Animal) with No Supplemental Precipitation].

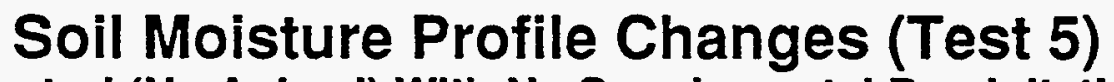

Control (No Animal) With No Supplemental Precipitation

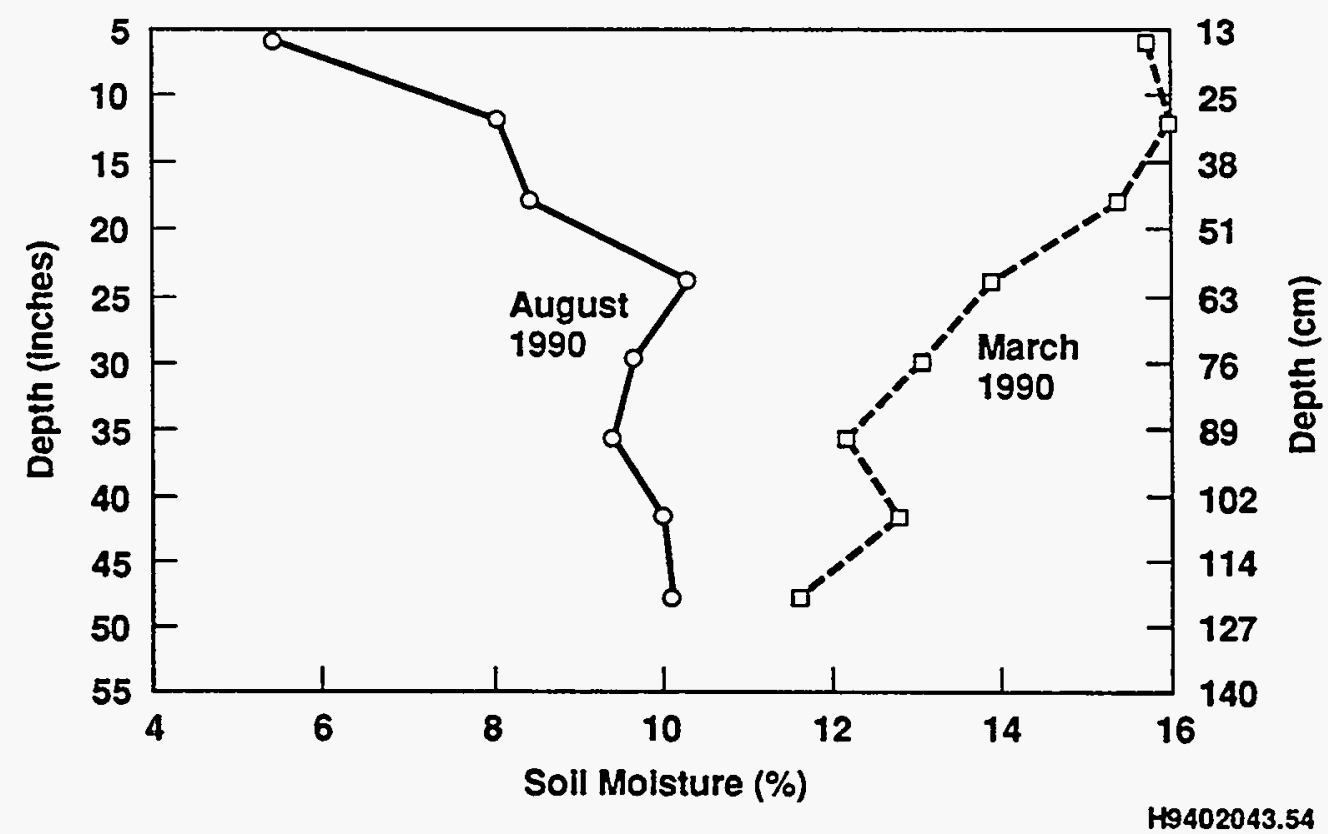


Figure C-23. Soil Moisture Profile Changes (Test 5) (Townsend with No Supplemental Precipitation).

\section{Soil Moisture Profile Changes (Test 5)}

Townsend (With No Supplemental Precipitation)

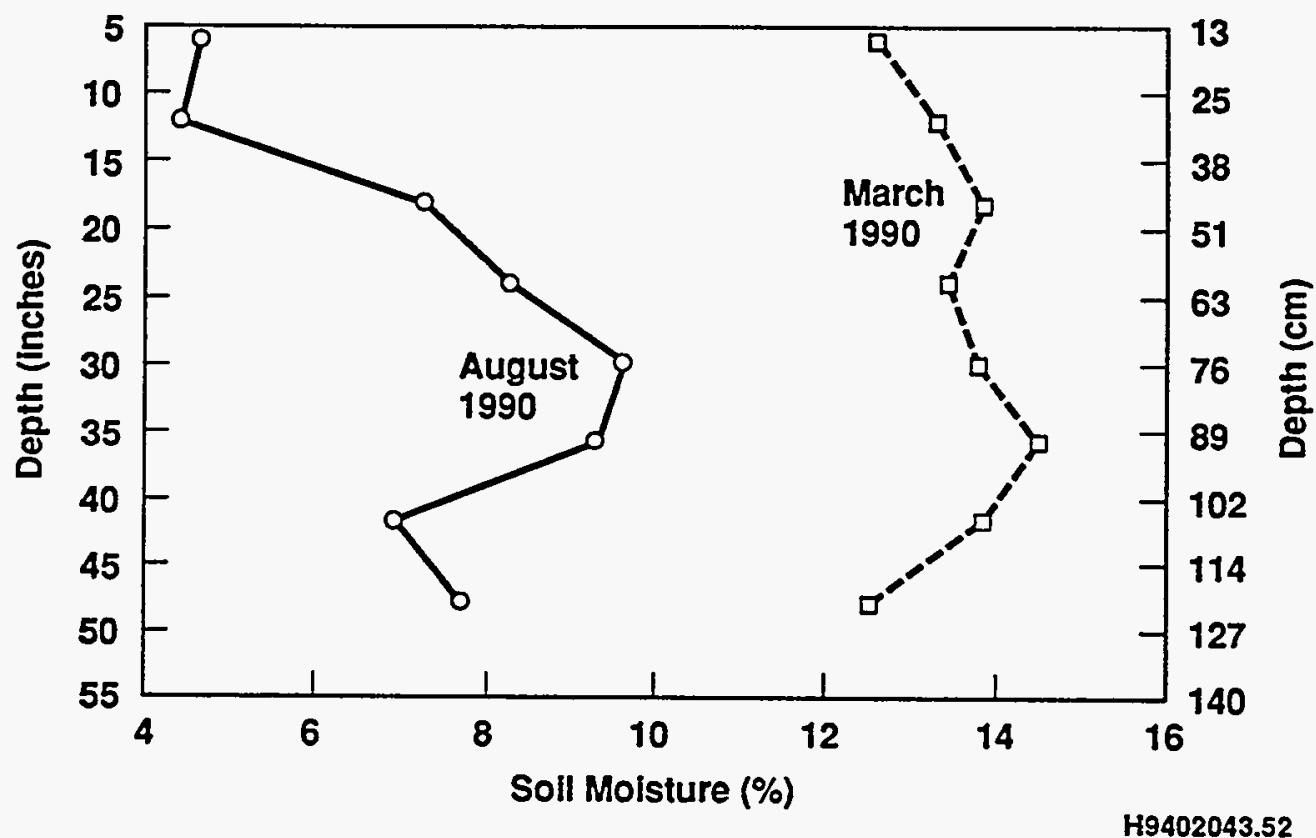

Figure C-24. Soil Moisture Profile Changes (Test 5) [Control (No Animal) with Supplemental Precipitation].

\section{Soil Moisture Profile Changes (Test 5)} Control (No Animal) With Supplemental Precipitation

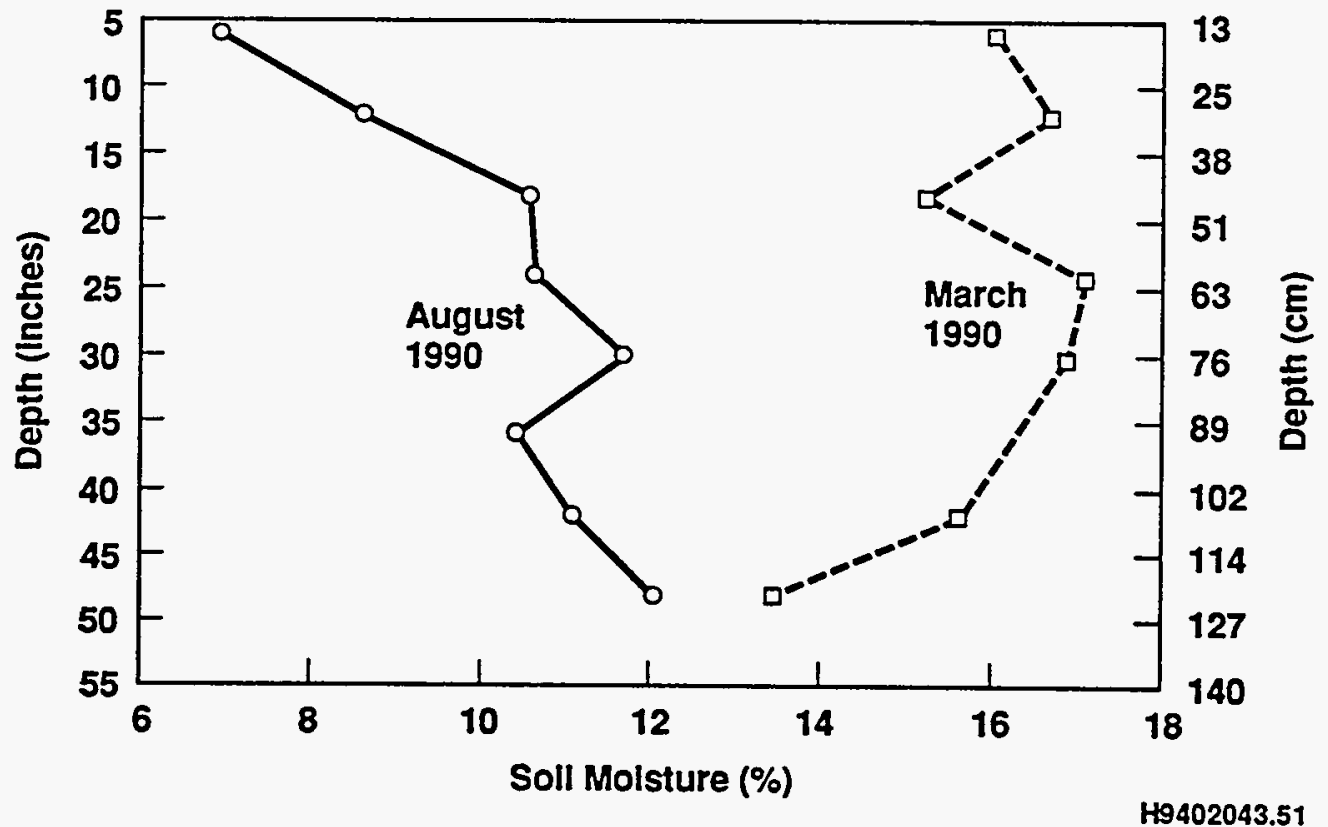


Figure C-25. Soil Moisture Profile Changes (Test 5)

(Townsend with Supplemental Precipitation).

\section{Soil Moisture Profile Changes (Test 5) Townsend (With Supplemental Precipitation)}

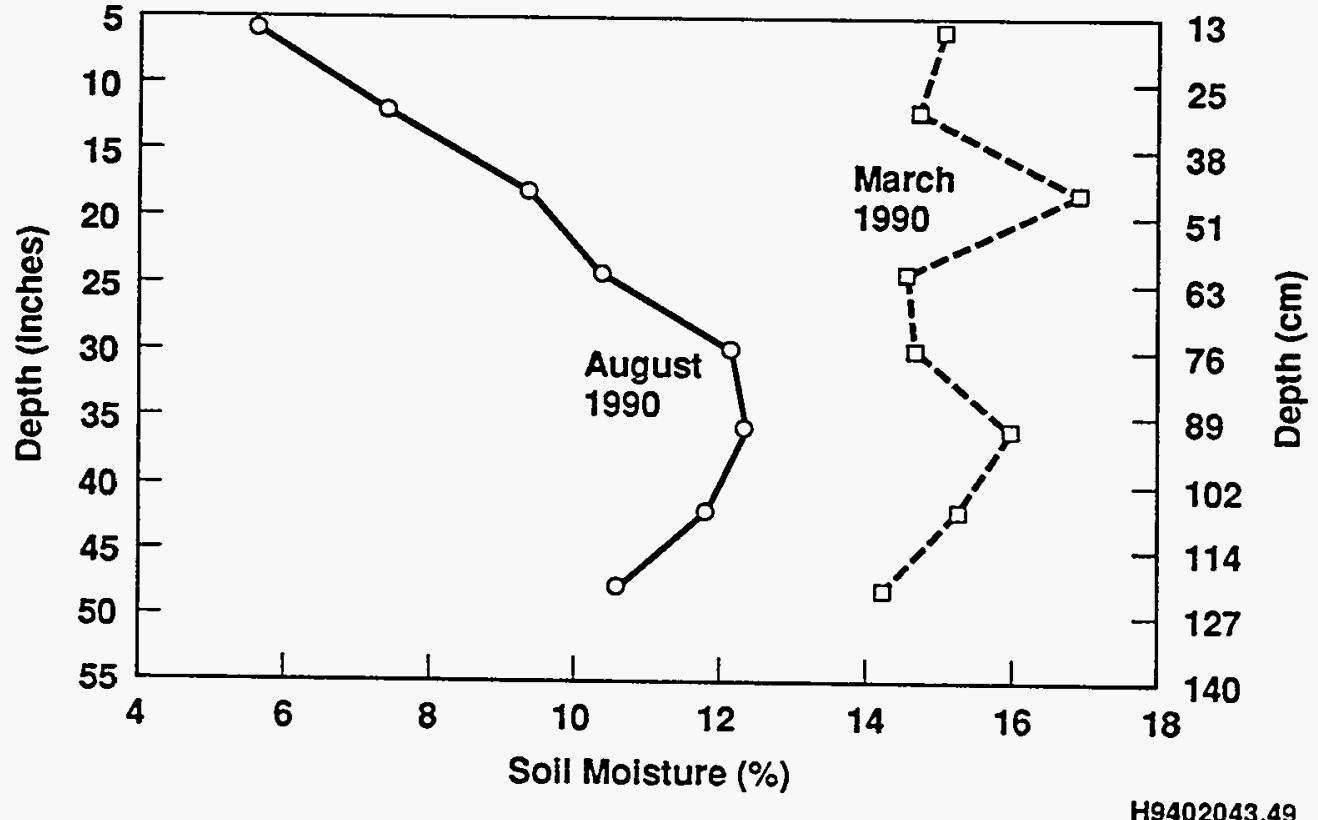


WHC-EP-0730

APPENDIX D

SOIL MOISTURE GRAPHS GENERATED FROM CONDUCTANCE AND HYDROPROBE DATA FOR TESTS 1 THROUGH 5

D-1 
Figure D-1. Conductivity Resistance (Test 1)-Summer (Pocket Mouse with No Supplemental Precipitation).

\section{Conductivity Resistance (Test 1)} Summer

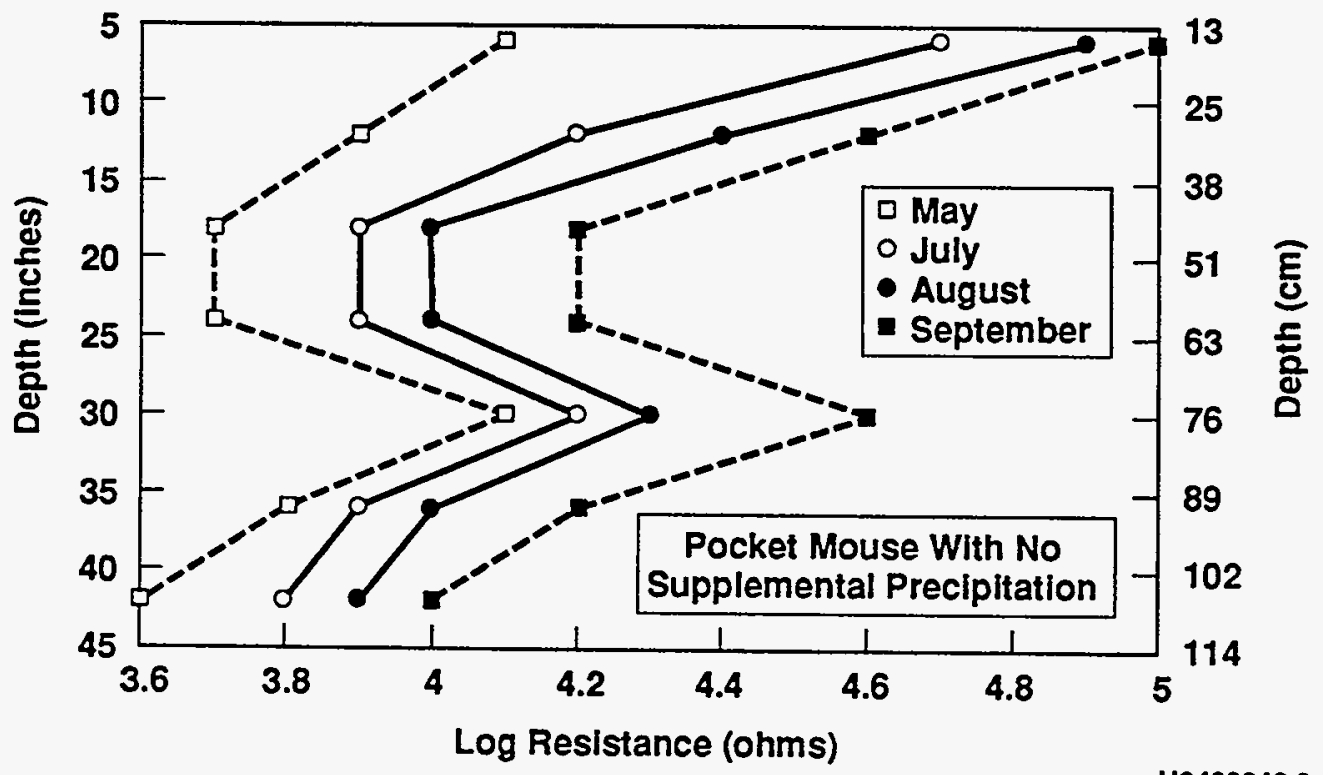

Figure D-2. Conductivity Resistance (Test 1)-Summer (Townsend with No Supplemental Precipitation).

\section{Conductivity Resistance (Test 1)}

\section{Summer}

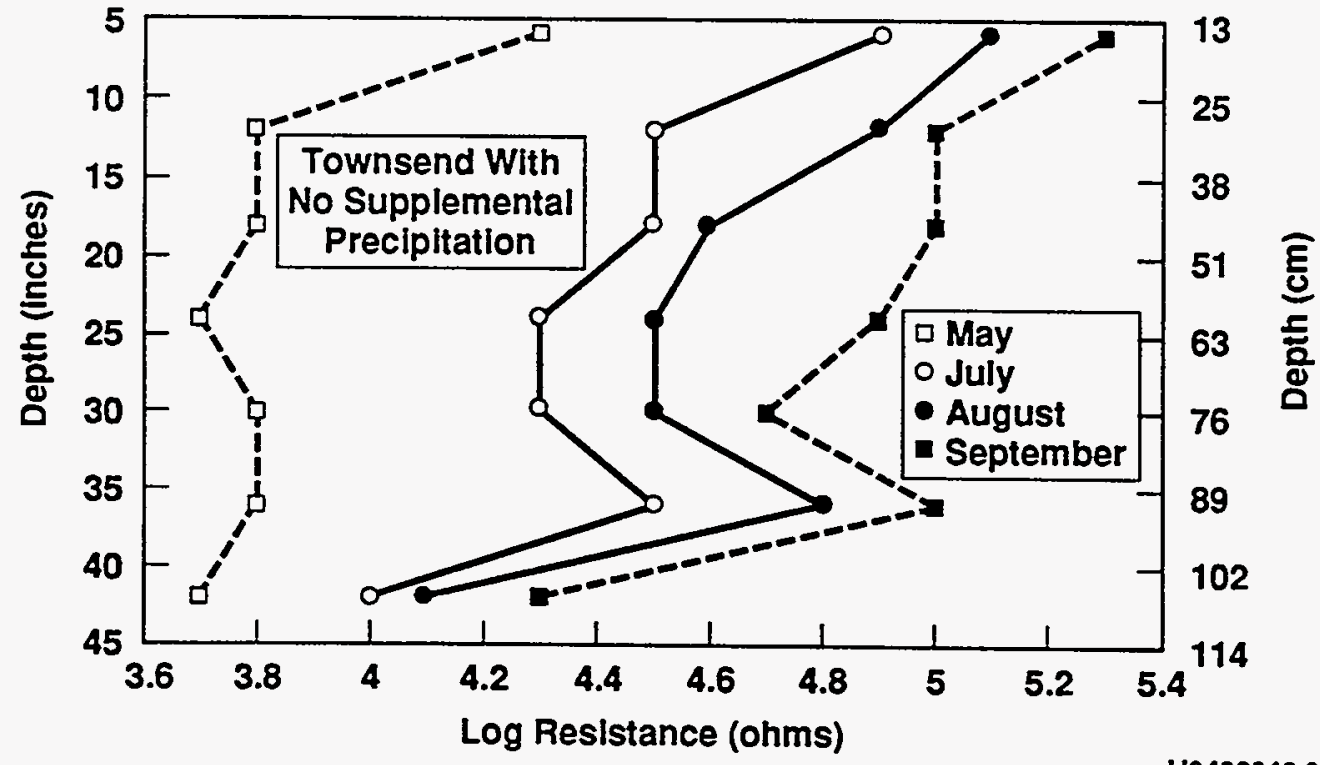

H9402043.9 
Figure D-3. Conductivity Resistance (Test 1)-Summer [Control (No Animal) with No Supplemental Precipitation].

\section{Conductivity Resistance (Test 1)} Summer

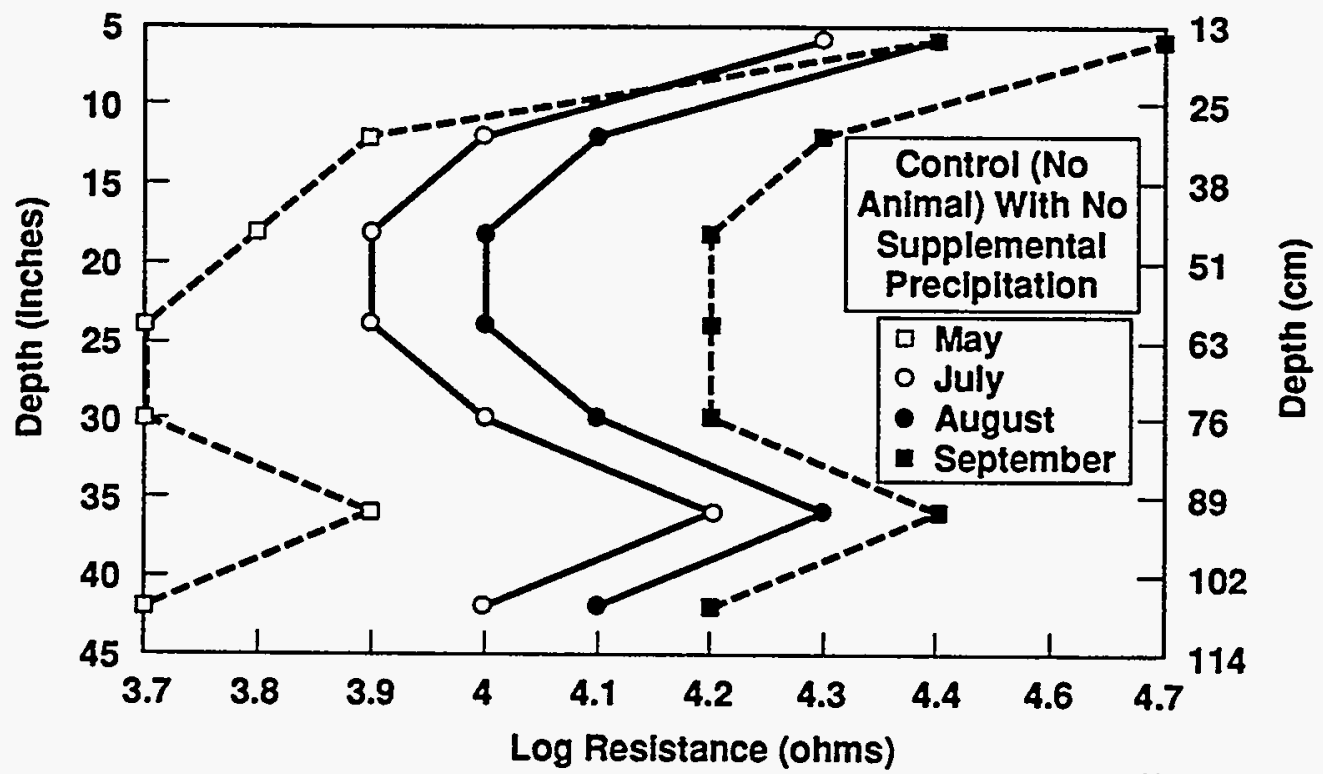

H9402043.10

Figure D-4. Conductivity Resistance (Test 1)-Summer (Townsend with Supplemental Precipitation).

\section{Conductivity Resistance (Test 1)} Summer

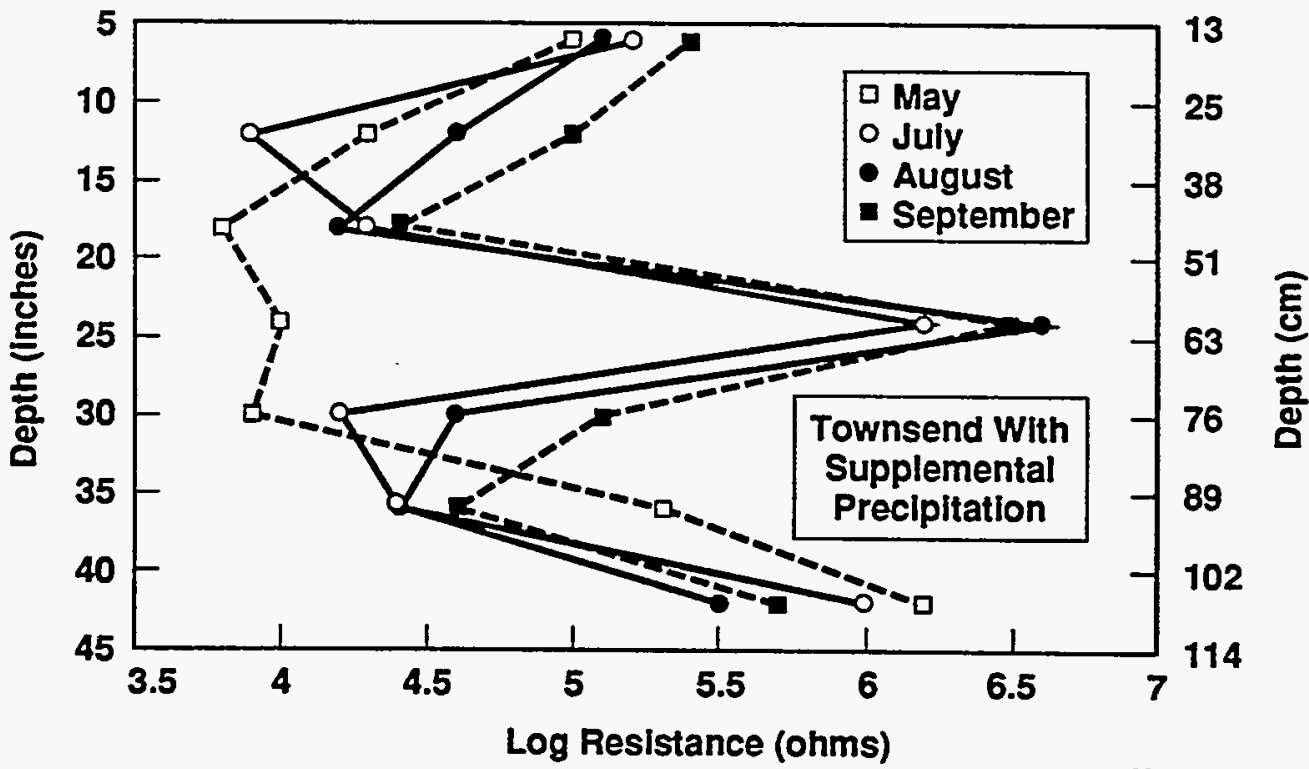

H9402043.11 
Figure D-5. Conductivity Resistance (Test 1)-Summer (Pocket Mouse with Supplemental Precipitation).

\section{Conductivity Resistance (Test 1)} Summer

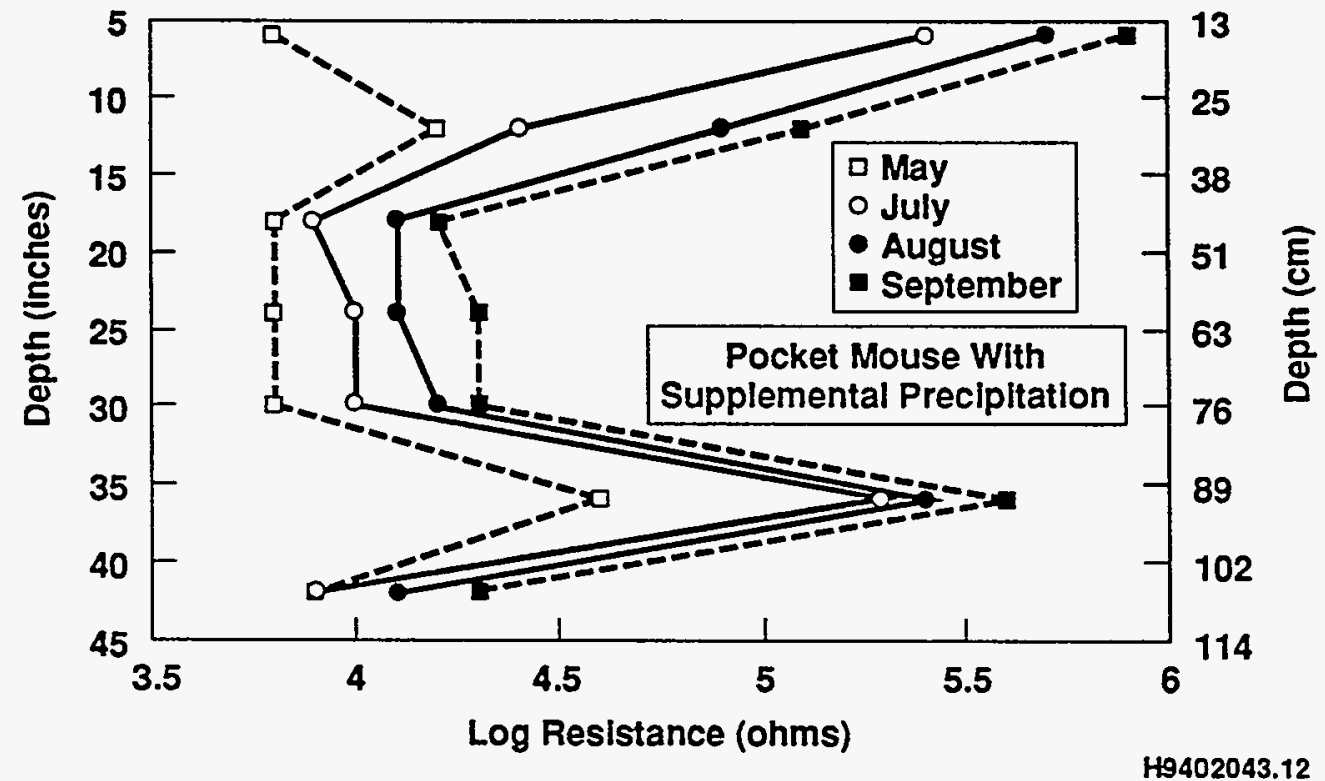

Figure D-6. Conductivity Resistance (Test 1)-Summer [Control (No Animal) with Supplemental Precipitation].

\section{Conductivity Resistance (Test 1) Summer}

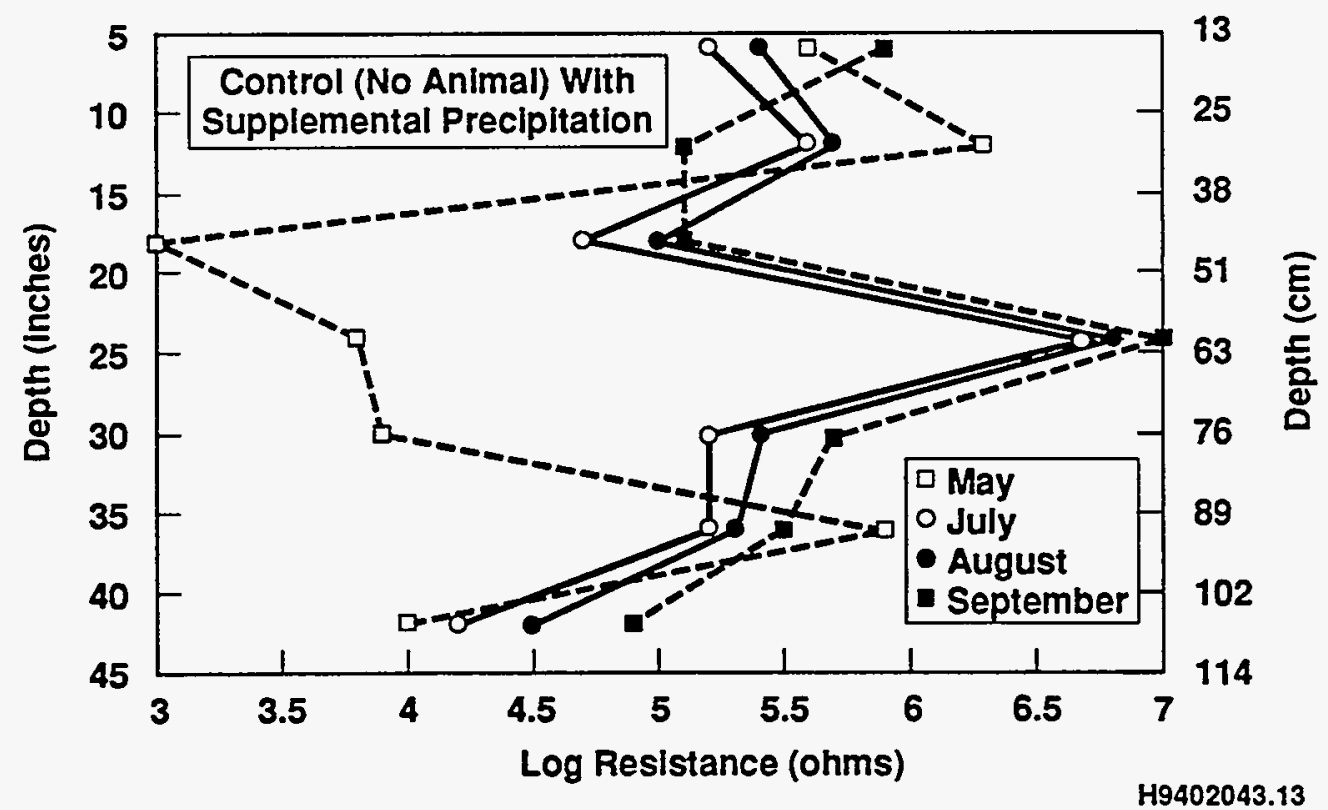


Figure D-7. Hydroprobe Readings (Test 2)-Winter (Pocket Gopher with No Supplemental Precipitation).

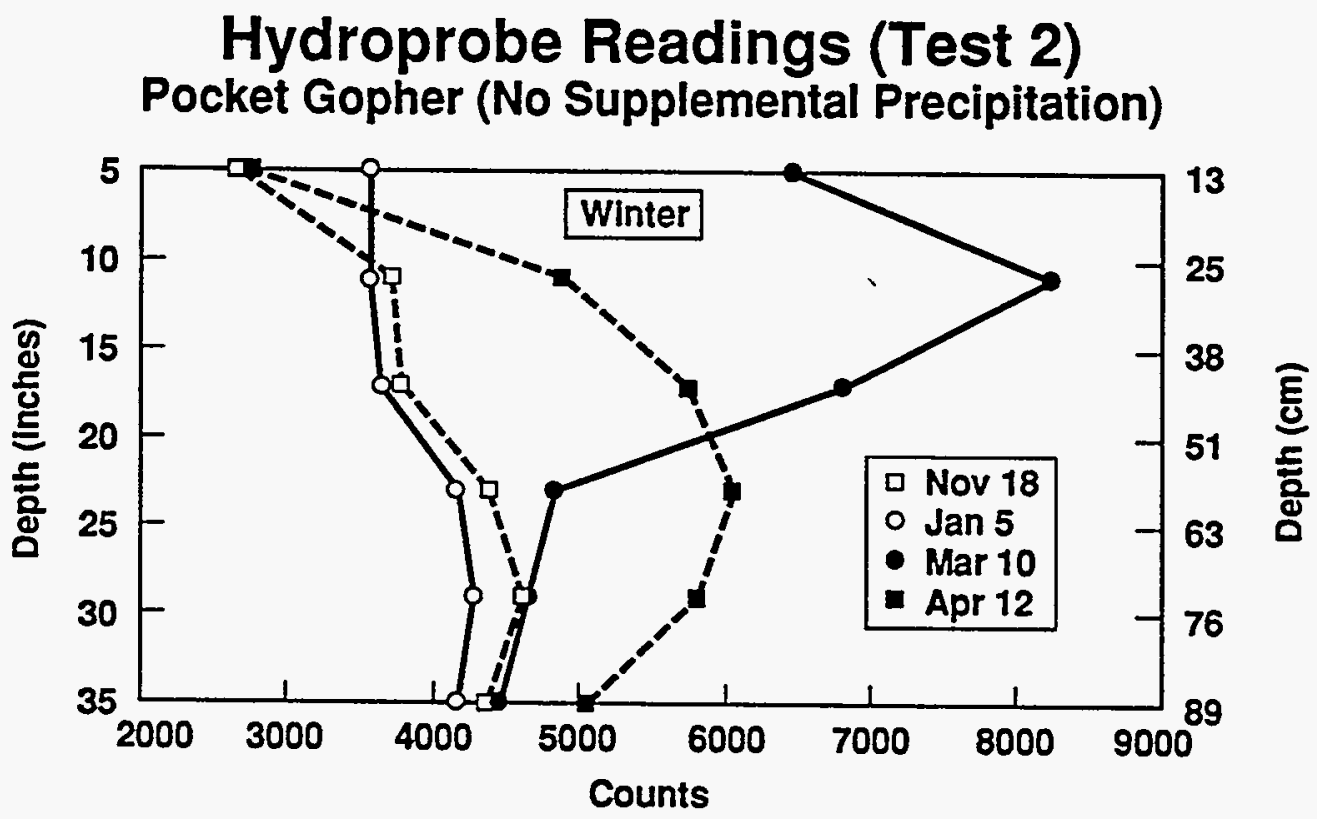

H9402043.21

Figure D-8. Hydroprobe Readings (Test 2)-Winter (Pocket Gopher with No Supplemental Precipitation).

Hydroprobe Readings (Test 2) Pocket Gopher (No Supplemental Precipitation)

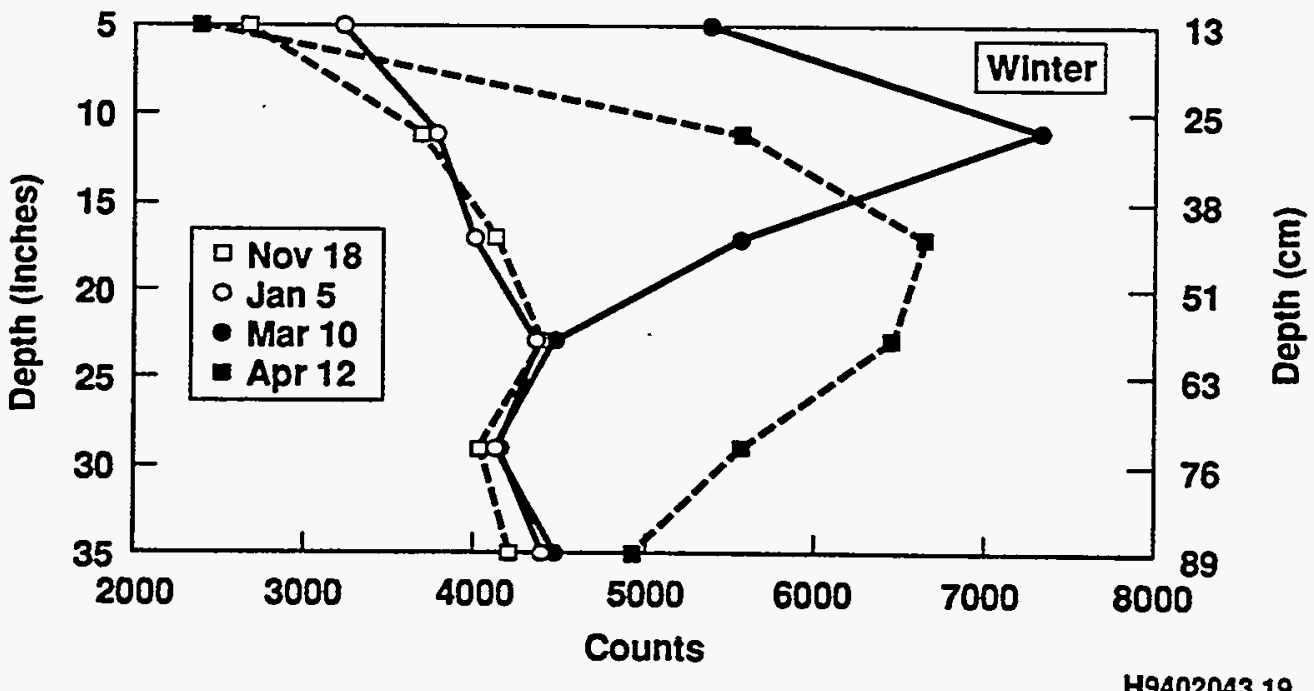


Figure D-9. Hydroprobe Readings (Test 2)-Winter (Pocket Mouse with No Supplemental Precipitation).

Hydroprobe Readings (Test 2) Pocket Mouse (No Supplemental Precipitation)

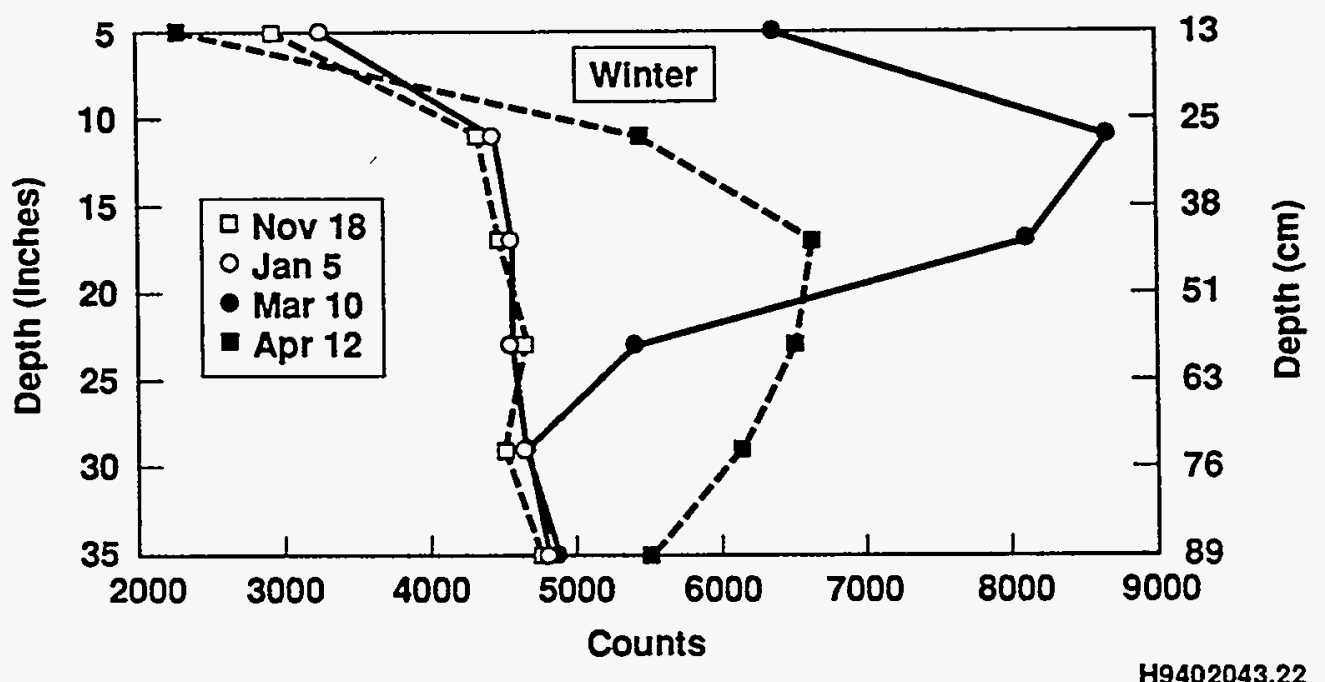

Figure D-10. Hydroprobe Readings (Test 2)-Winter [Control (No Animal) with No Supplemental Precipitation].

\section{Hydroprobe Readings (Test 2)}
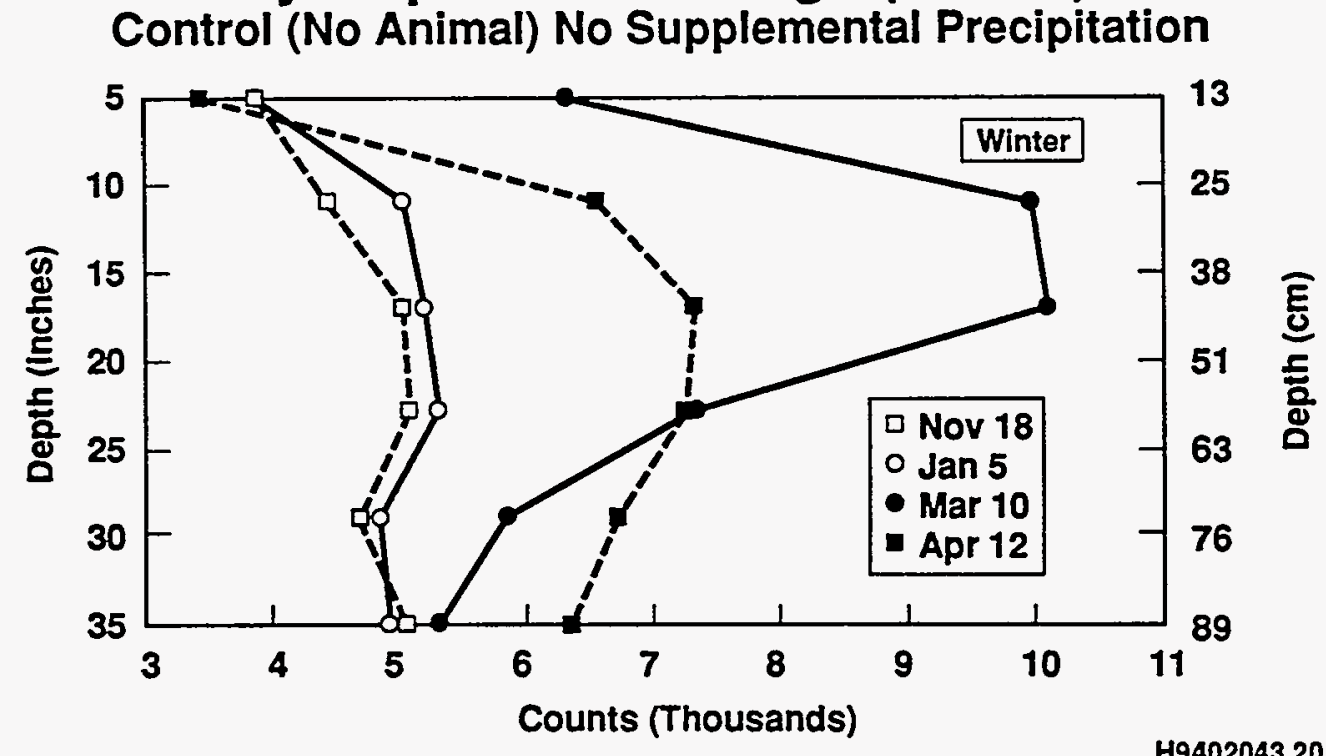
Figure D-11. Hydroprobe Readings (Test 3)-Summer [Control (No Animal) with No Supplemental Precipitation].

Hydroprobe Readings (Test 3) Control (No Animal) With No Supplemental Precipitation

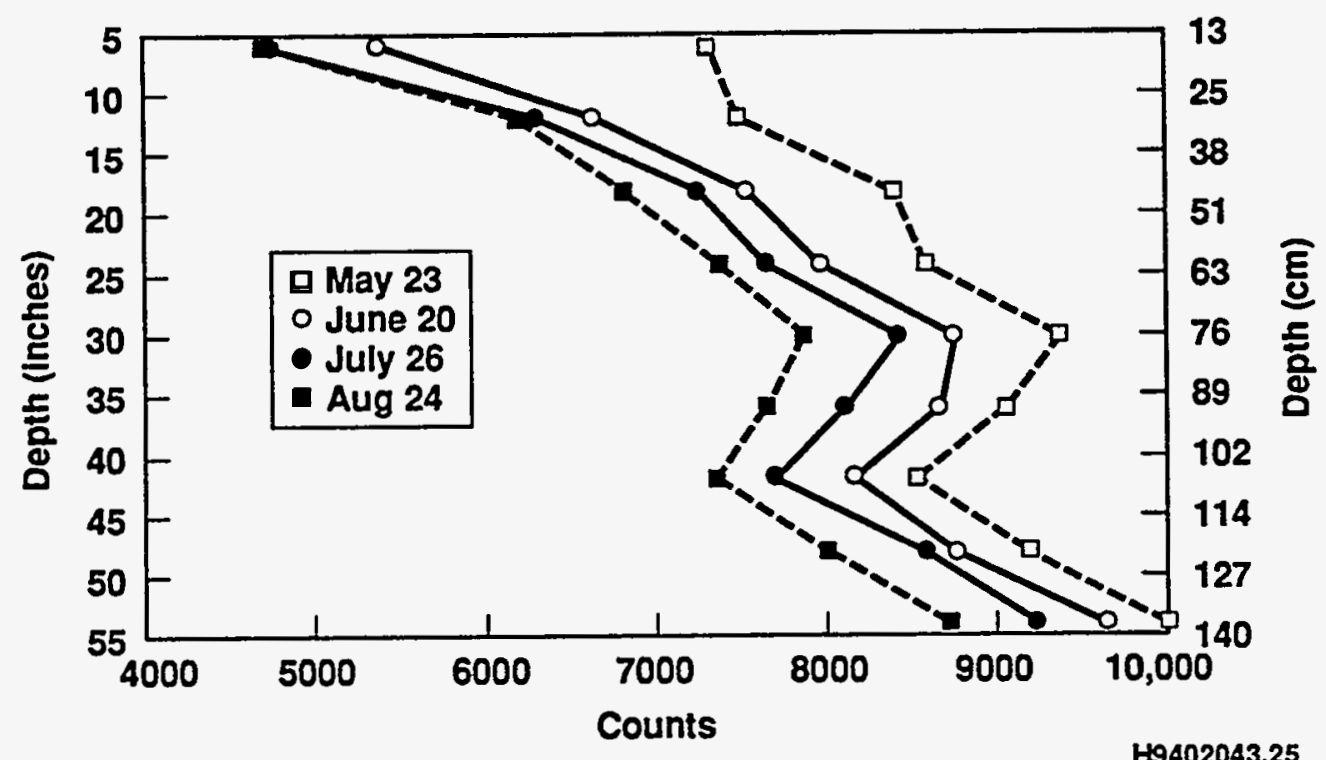

Figure D-12. Hydroprobe Readings (Test 3)-Summer (Pocket Gopher with No Supplemental Precipitation).

Hydroprobe Readings (Test 3 ) Pocket Gopher (No Supplemental Precipitation)

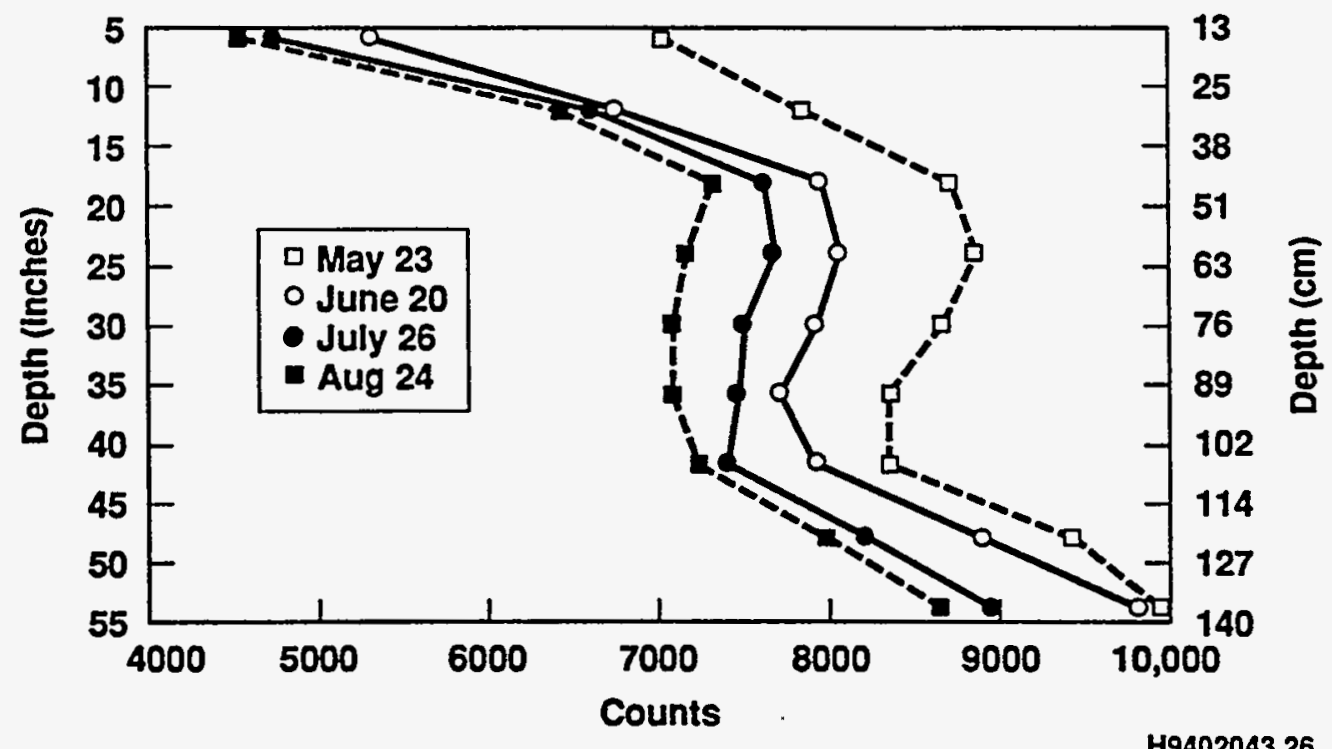


Figure D-13. Hydroprobe Readings (Test 3)-Summer (Townsend with No Supplemental Precipitation).

\section{Hydroprobe Readings (Test 3)}

Townsend (No Supplemental Precipitation)

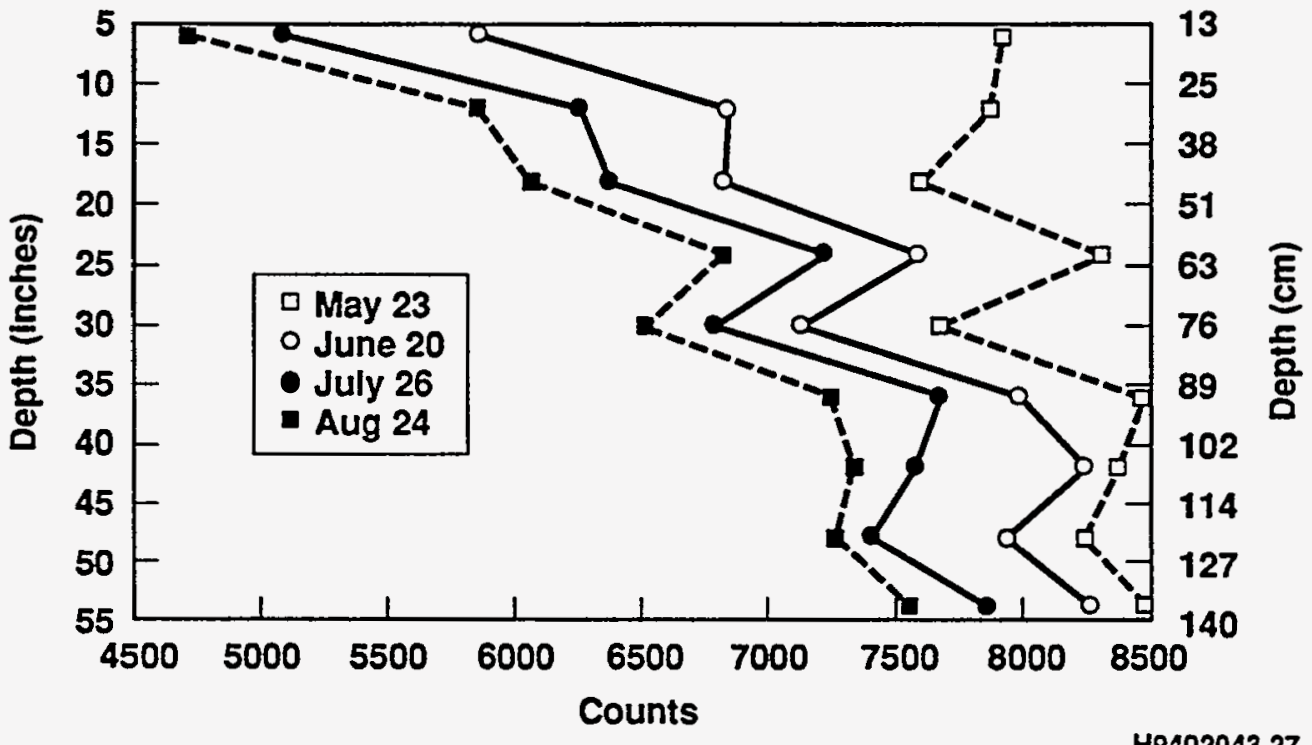

Figure D-14. Hydroprobe Readings (Test 3)-Summer [Control (No Animal) with Supplemental Precipitation].

Hydroprobe Readings (Test 3 ) Control (No Animal) With Supplemental Precipitation

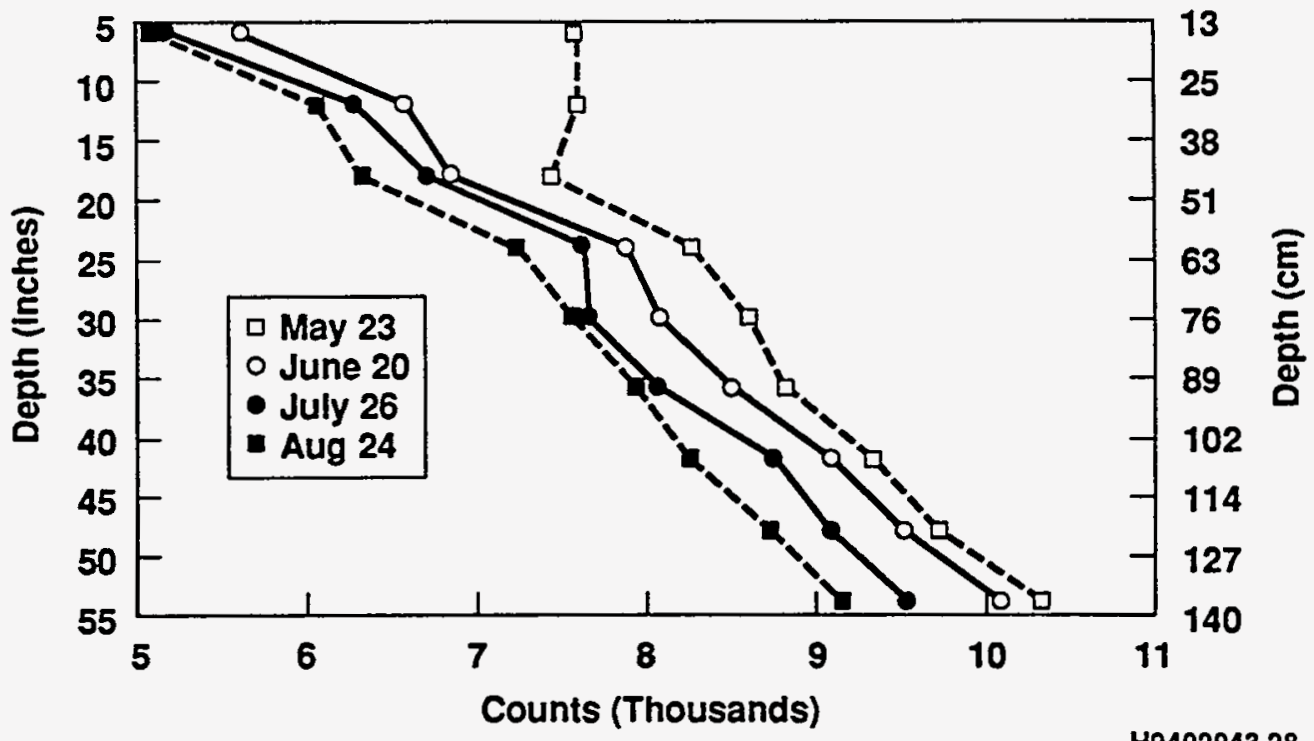


Figure D-15. Hydroprobe Readings (Test 3)-Summer (Townsend with Supplemental Precipitation).

Hydroprobe Readings (Test 3)

Townsend (With Supplemental Precipitation)

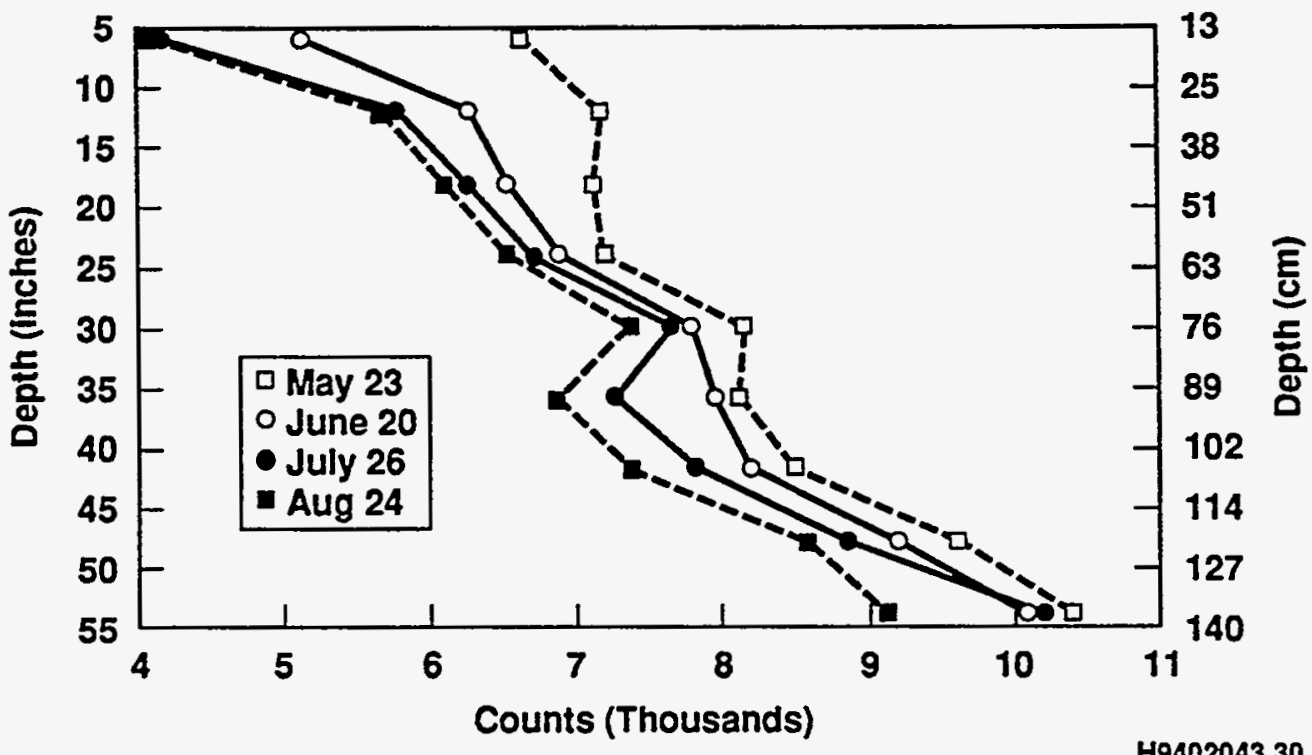

Figure D-16. Hydroprobe Readings (Test 4)-Winter (Pocket Gopher with No Supplemental Precipitation).

Hydroprobe Readings (Test 4) Pocket Gopher (With No Supplemental Precipitation)

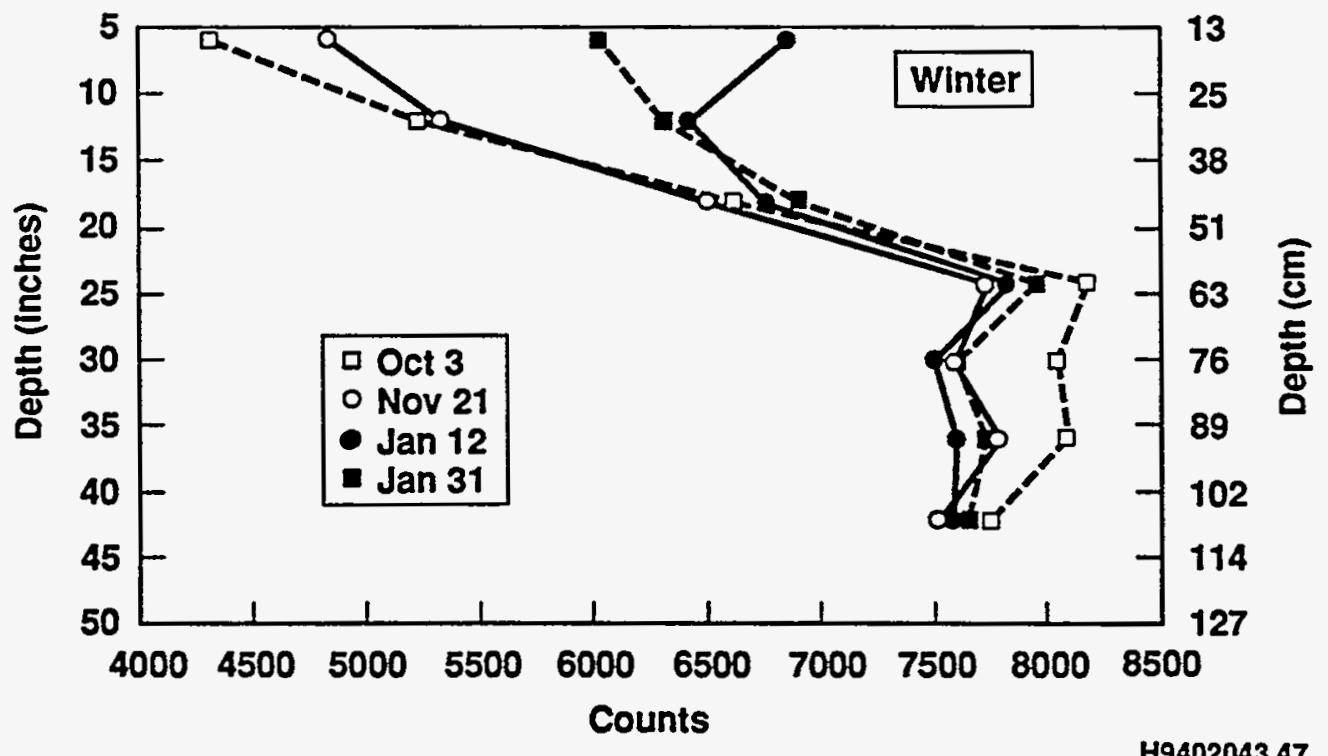


Figure D-17. Hydroprobe Readings (Test 4)-Winter

[Control (No Animal) with No Supplemental Precipitation].

Hydroprobe Readings (Test 4) Control (No Animal) With No Supplemental Precipitation

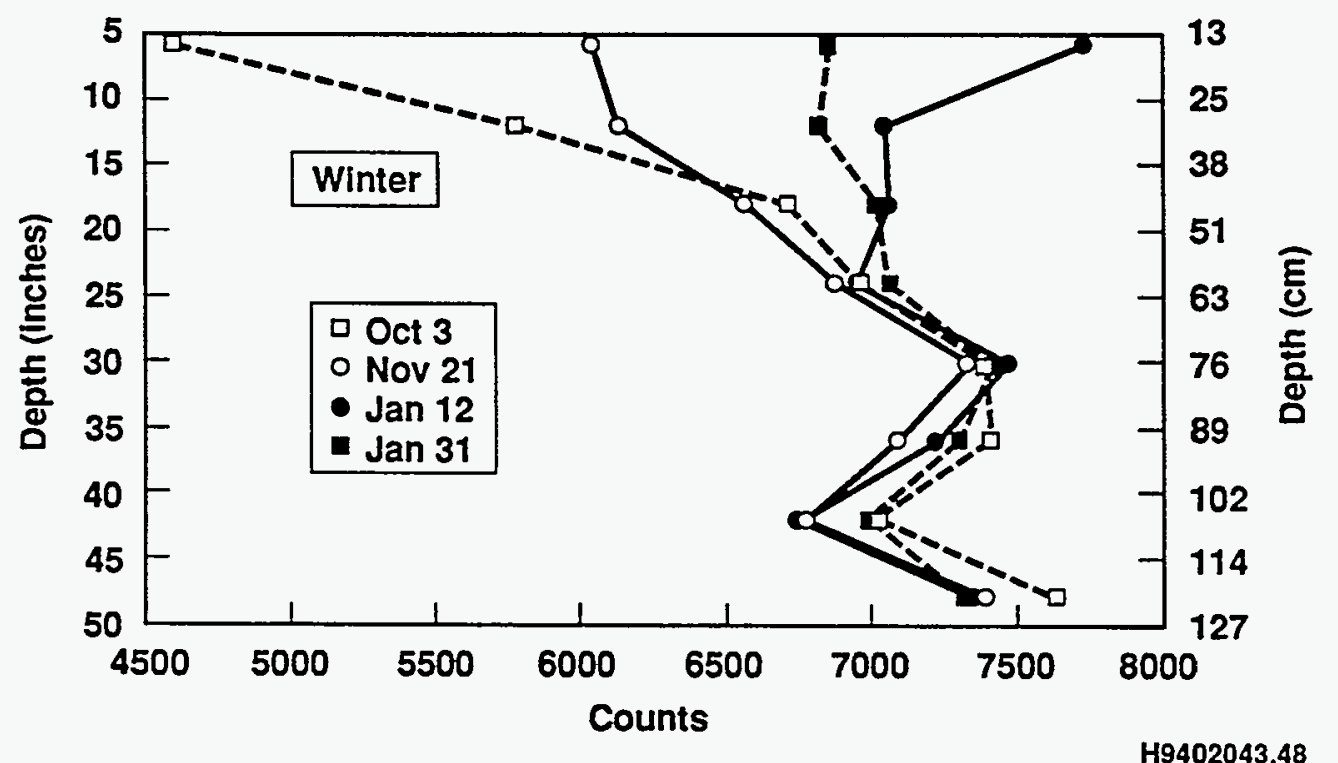

Figure D-18. Hydroprobe Readings (Test 4)-Winter (Pocket Gopher with Supplemental Precipitation).

\section{Hydroprobe Readings (Test 4)}

Pocket Gopher (With Supplemental Precipitation)

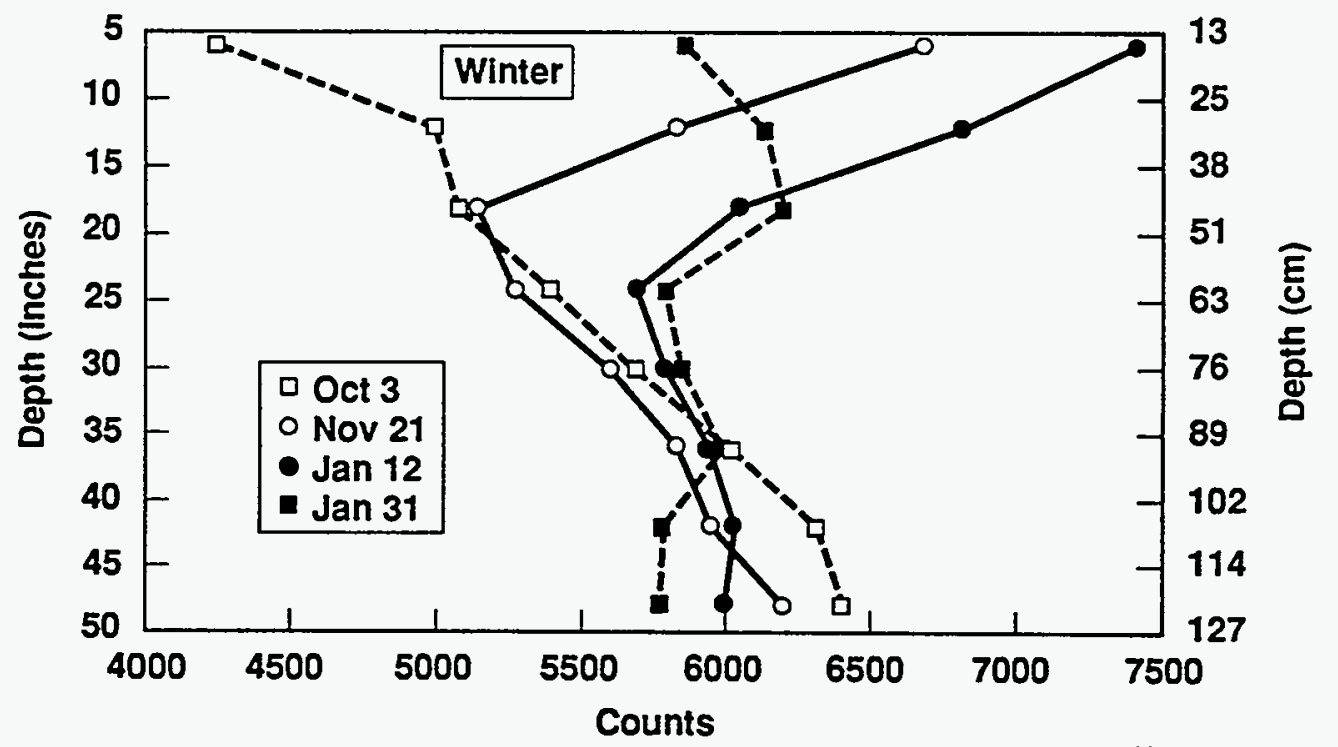


Figure D-19. Hydroprobe Readings (Test 4)-Winter

[Control (No Animal) with Supplemental Precipitation].

\section{Hydroprobe Readings (Test 4)}

Control (No Animal) With Supplemental Precipitation

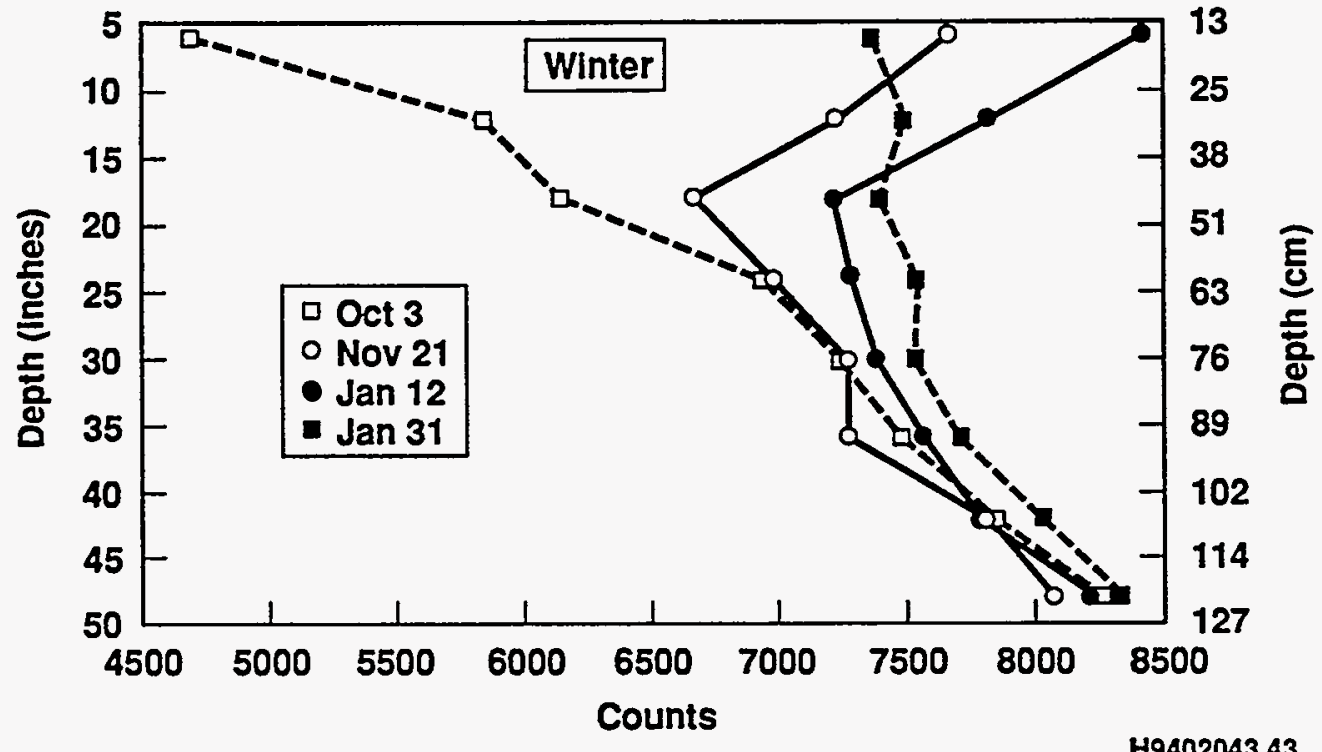

Figure D-20. Hydroprobe Readings (Test 5)-Summer

(Townsend with Supplemental Precipitation).

Hydroprobe Readings (Test 5)

Townsend (With Supplemental Precipitation)

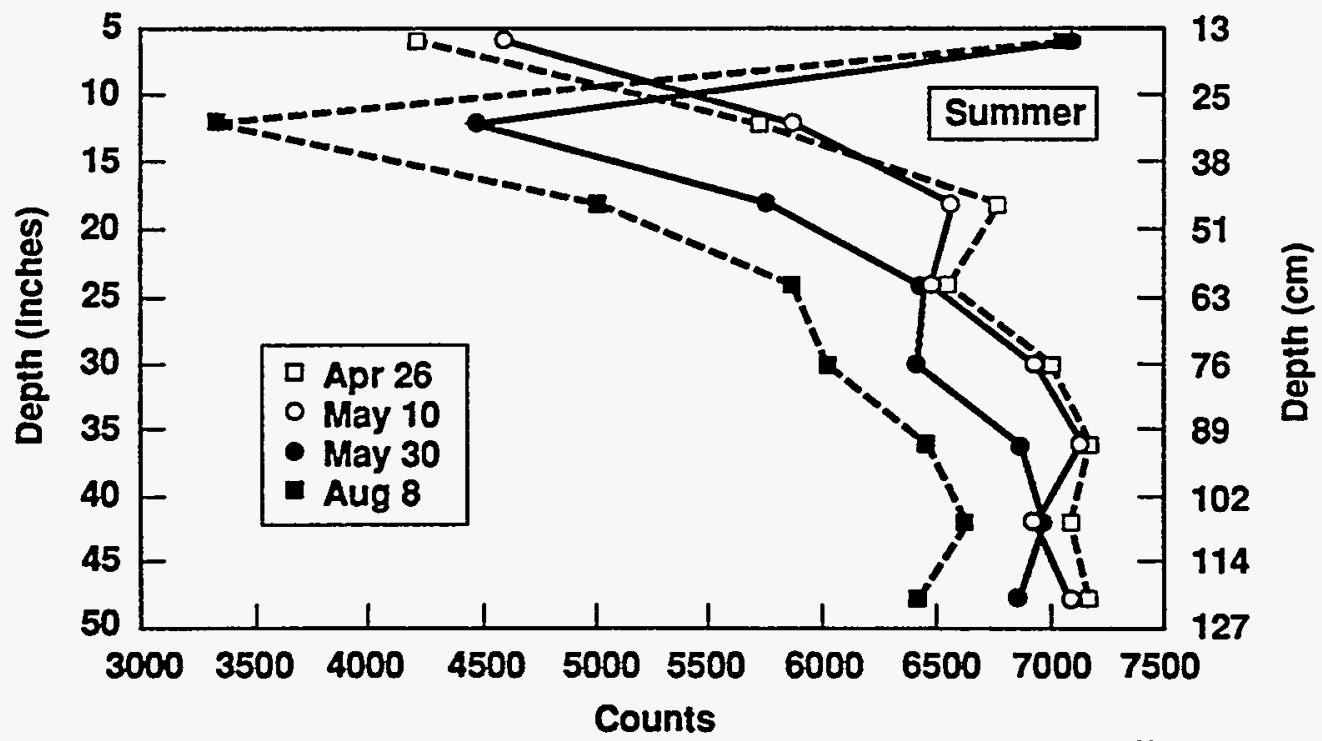

H9402043.59 
WHC-EP-0730

Figure D-21. Hydroprobe Readings (Test 5)-Summer

(Townsend with No Supplemental Precipitation).

Hydroprobe Readings (Test 5)

Townsend (With No Supplemental Precipitation)

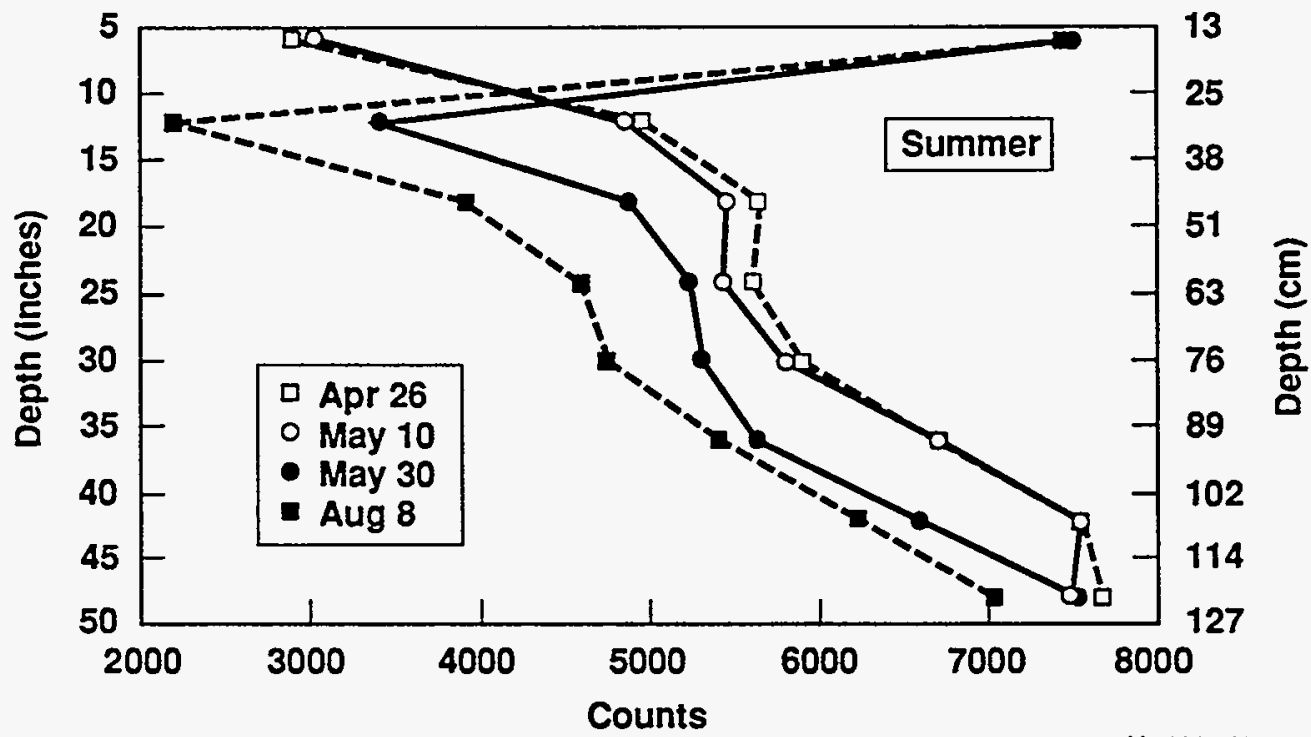

H9402043.57

Figure D-22. Hydroprobe Readings (Test 5)-Summer [Control (No Animal) with Supplemental Precipitation].

Hydroprobe Readings (Test 5) Control (No Animal) With Supplemental Precipitation

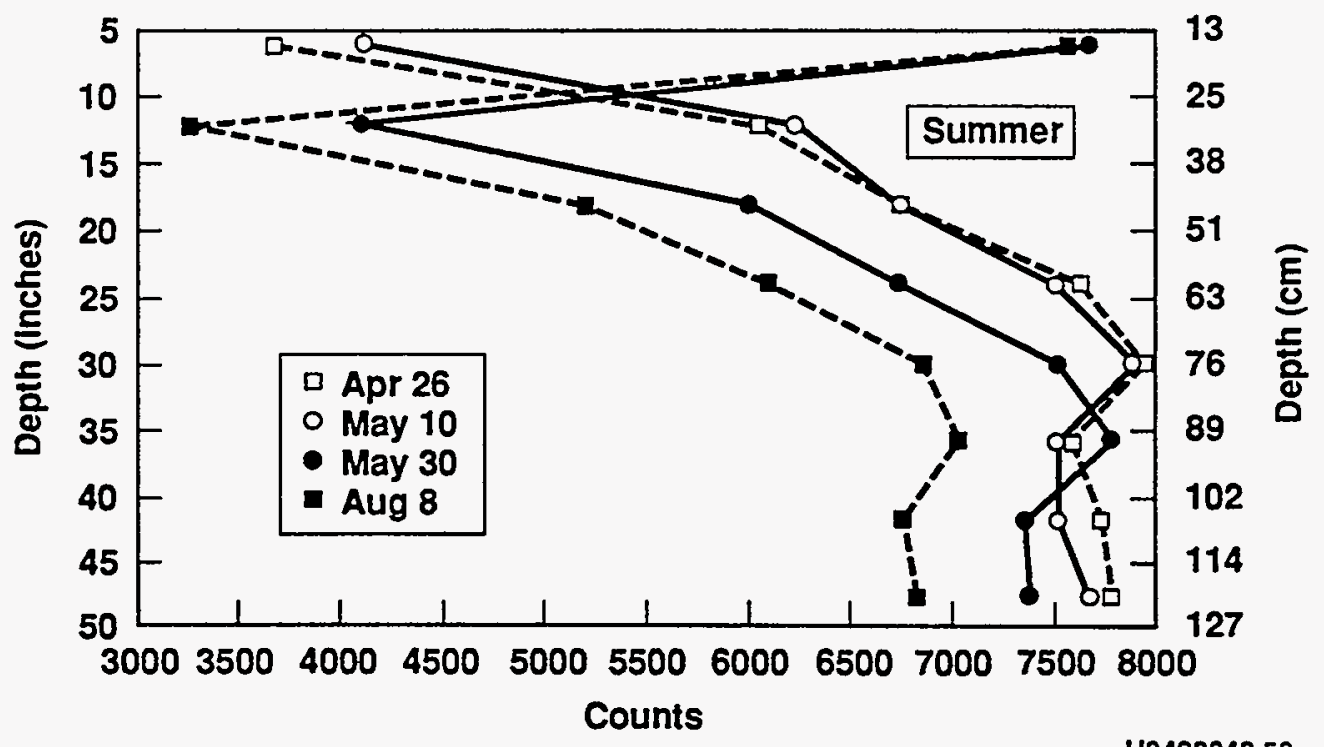

H9402043.58 
Figure D-23. Hydroprobe Readings (Test 5)-Summer [Control (No Animal) with No Supplemental Precipitation].

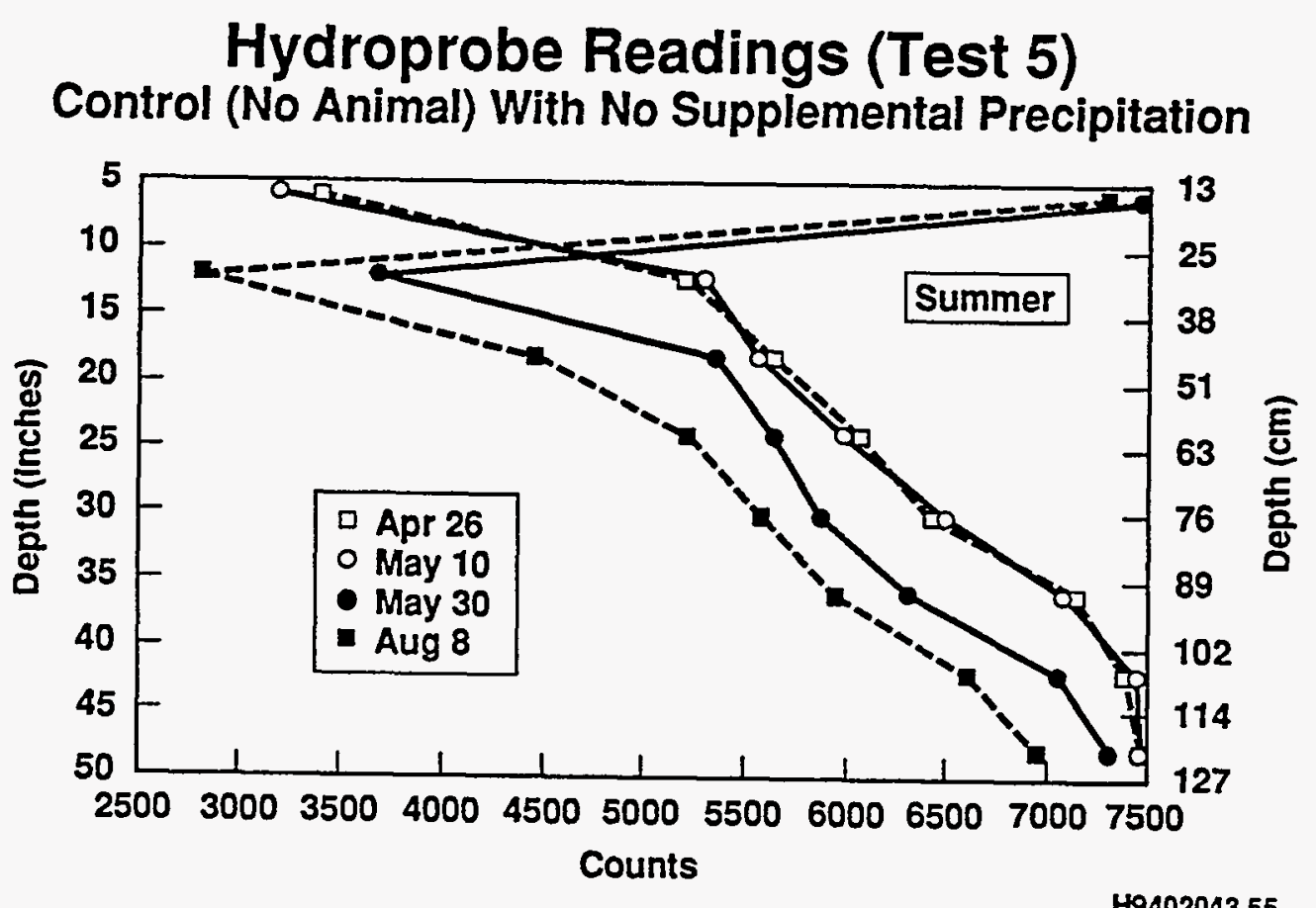


WHC-EP-0730

D-14 
WHC-EP-0730

\section{APPENDIX E}

\section{GREAT BASIN POCKET MOUSE BURROW SYSTEMS EXCAVATED}

AND MAPPED AT THE HANFORD SITE

E-1 
WHC-EP-0730

Figure E-1. Example of Great Basin Pocket Gopher Mounds that Become Elevated above Normal Landscape.

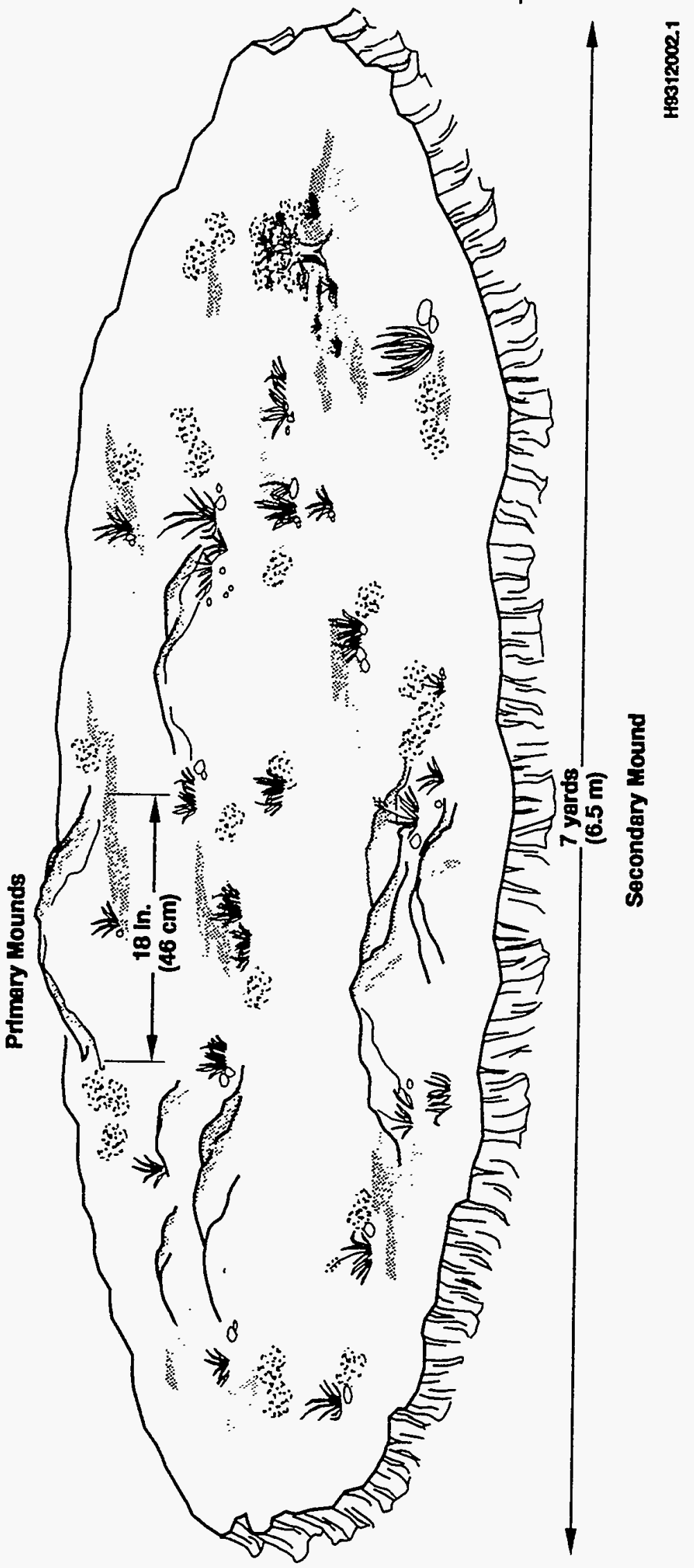

$\mathrm{E}-2$ 
Figure E-2. Cross Section of a Great Basin Pocket Mouse Burrow System Excavated at the Hanford Site.

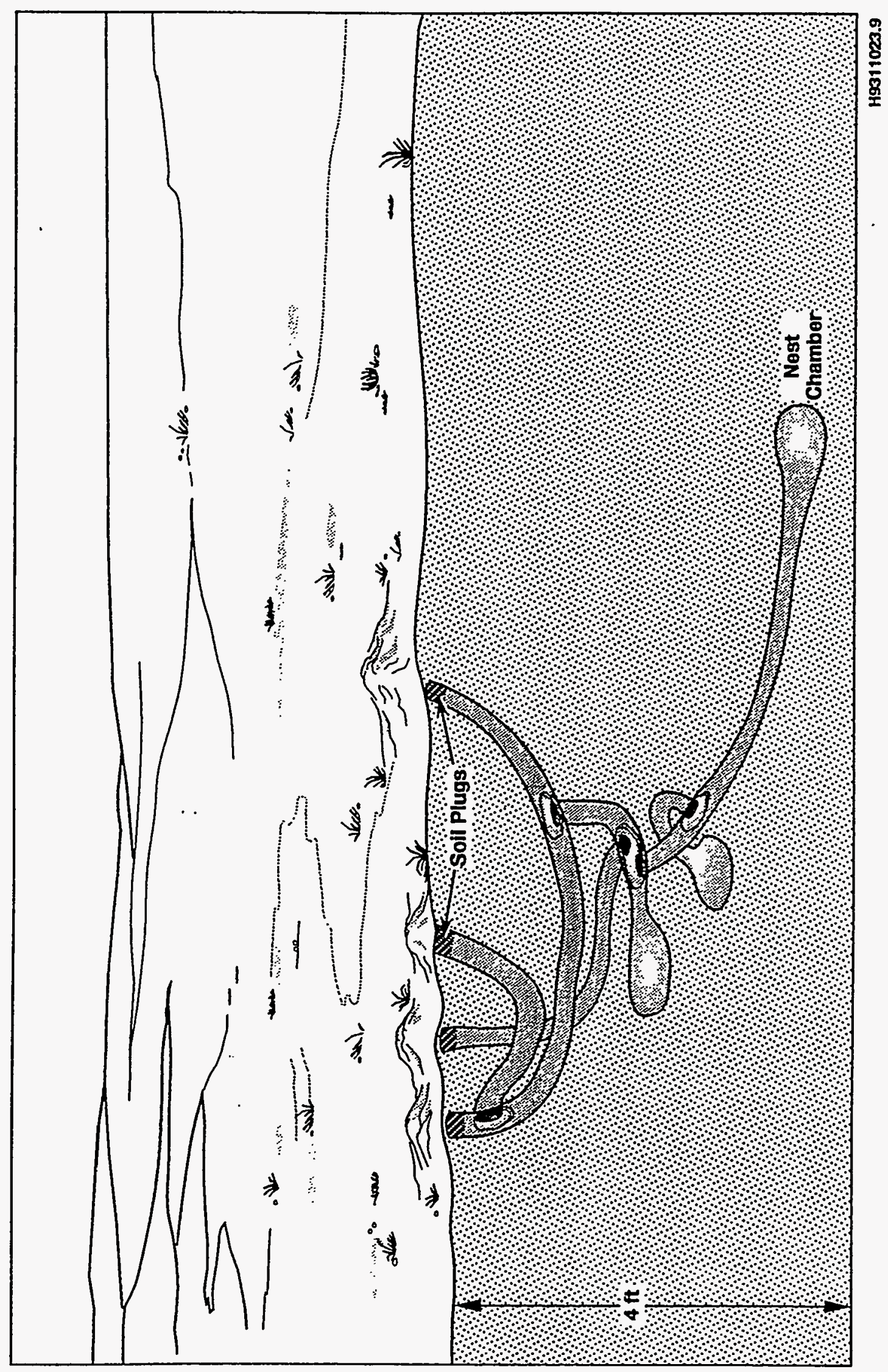




\section{WHC-EP-0730}

Figure E-3. Cross Section of a Great Basin Pocket Mouse Burrow System Excavated at the Hanford Site.

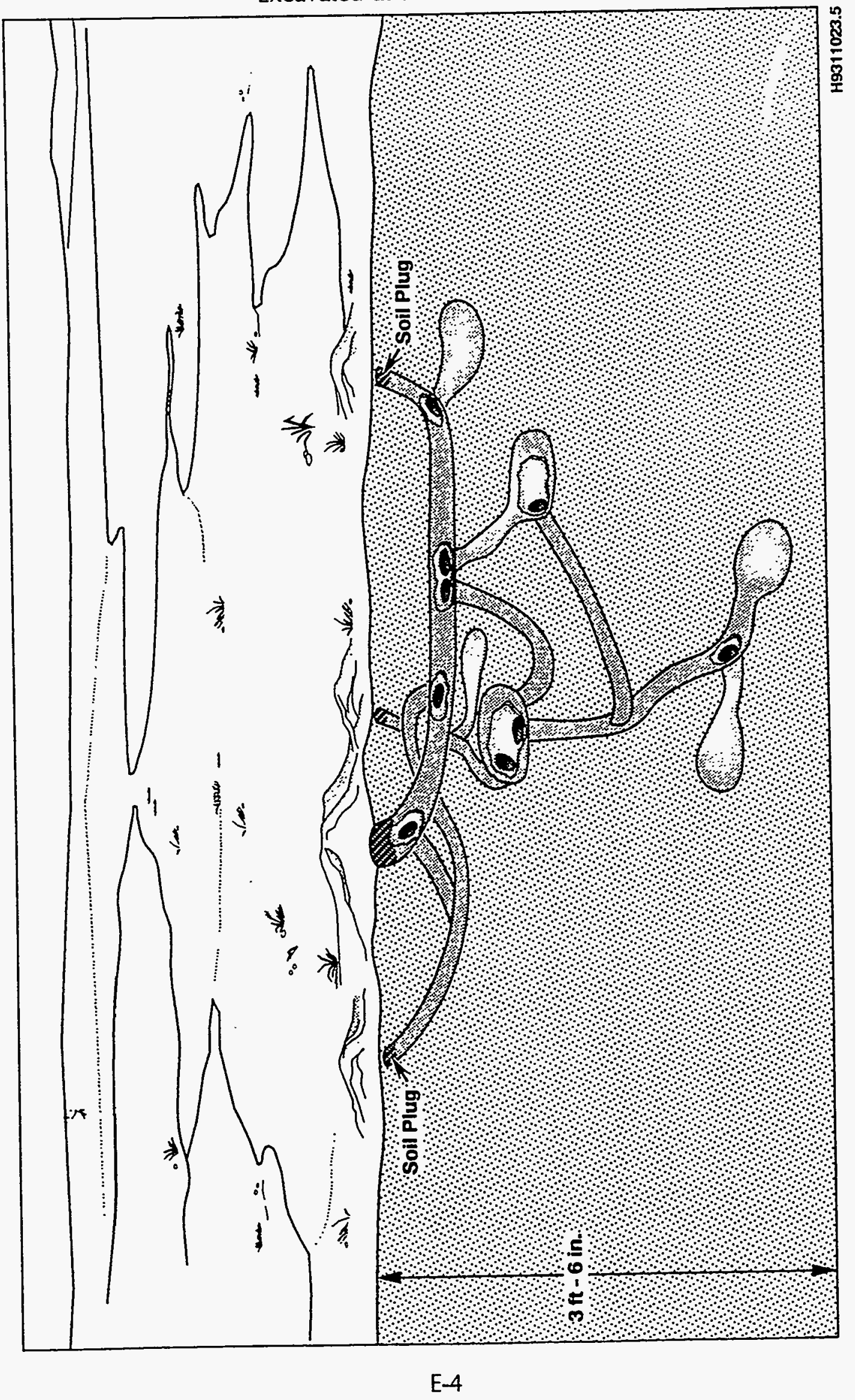


Figure E-4. Cross Section of a Great Basin Pocket Mouse Burrow System Excavated at the Hanford Site.

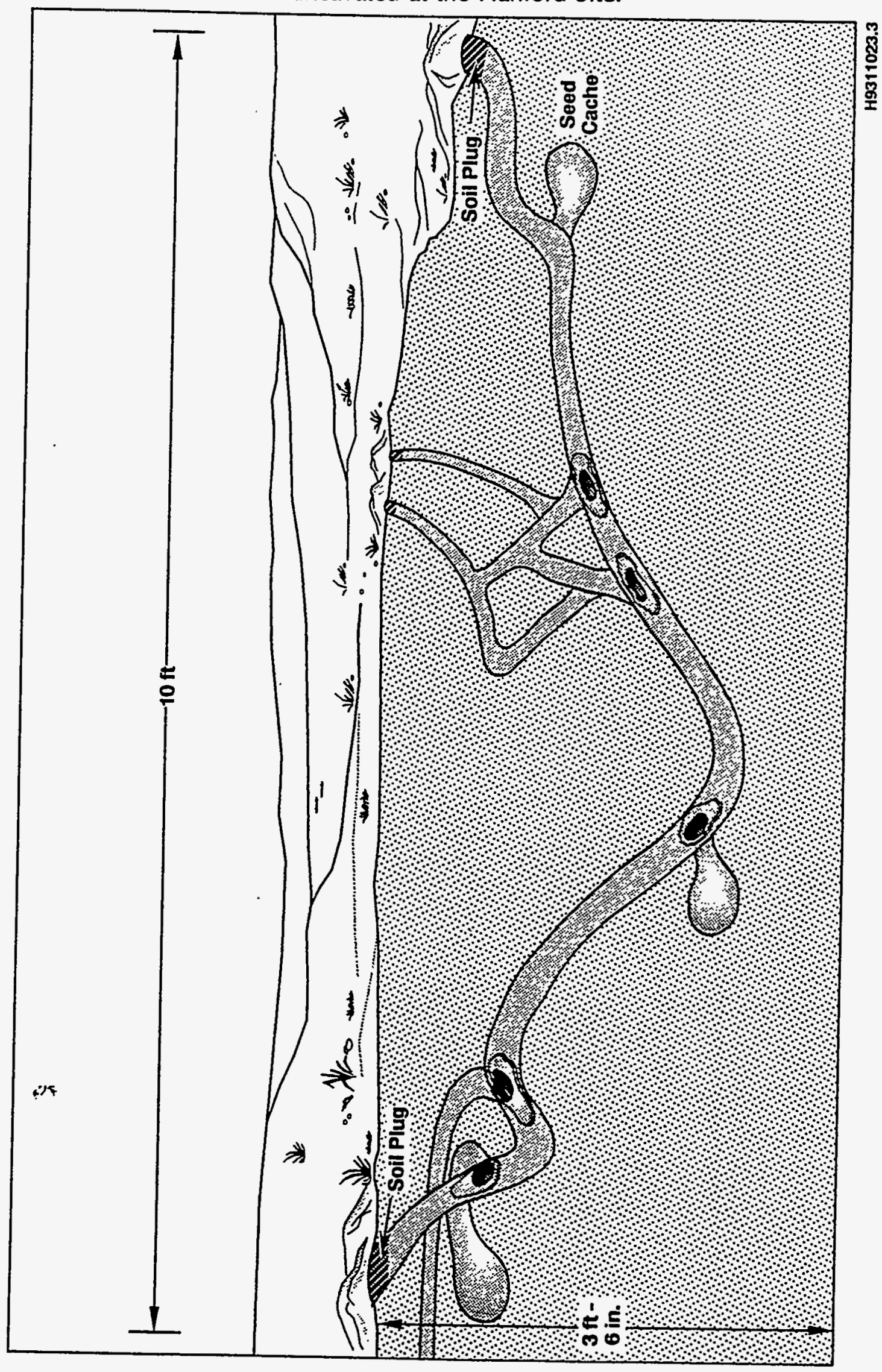

E-5 
Figure E-5. Cross Section of a Great Basin Pocket Mouse Burrow System Excavated at the Hanford Site.

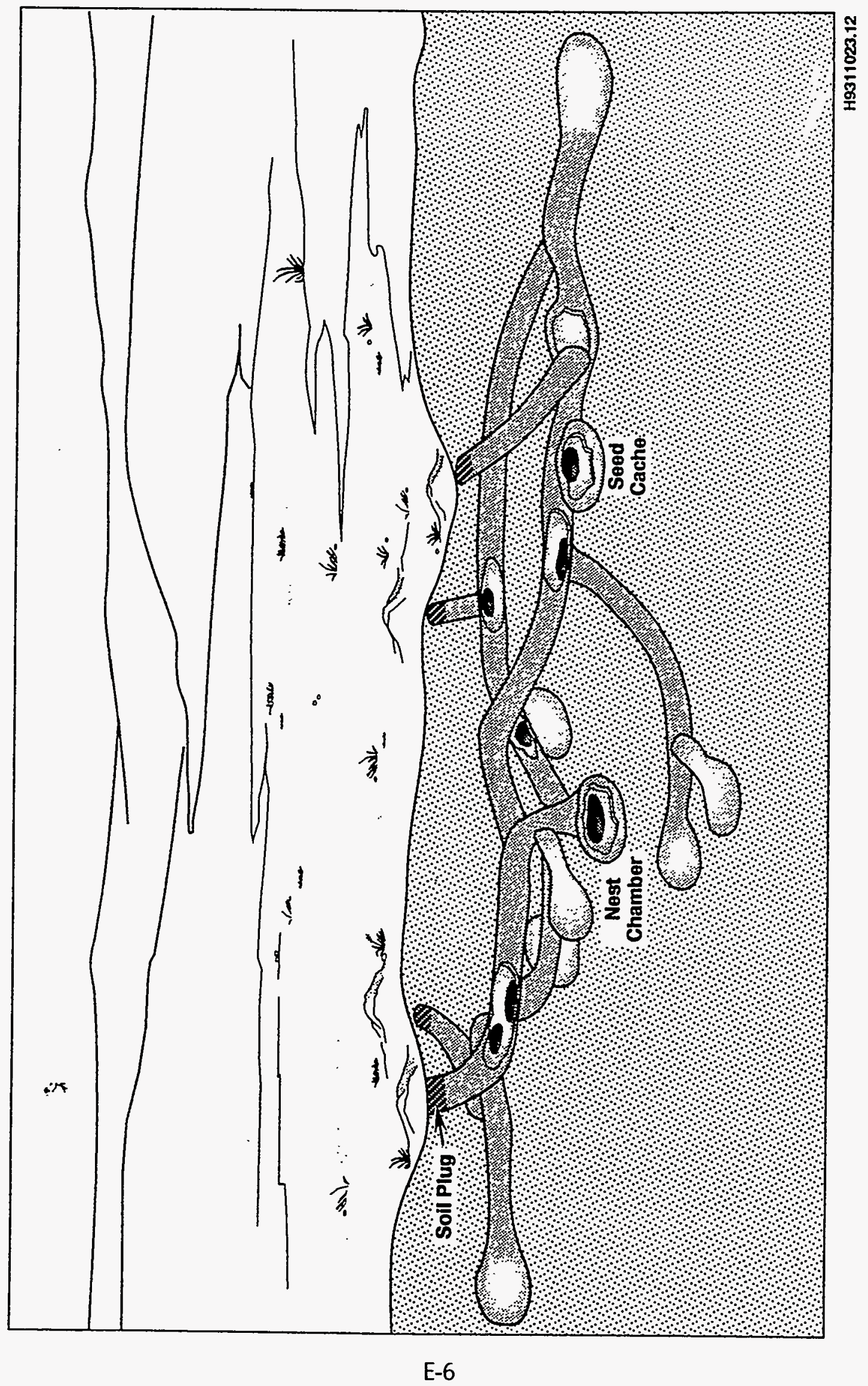

